WALTER GODOY DOS SANTOS JR.

\title{
O REGIME JURÍDICO DA PROTEÇÃO DA FORMA NA PROPRIEDADE INTELECTUAL
}

\author{
Tese de Doutorado
}

Orientador: Professor Doutor Newton Silveira

UNIVERSIDADE DE SÃO PAULO

FACULDADE DE DIREITO

São Paulo-SP

2017 
WALTER GODOY DOS SANTOS JR.

\section{O REGIME JURÍDICO DA PROTEÇÃO DA FORMA NA PROPRIEDADE INTELECTUAL}

Tese apresentada à Banca Examinadora do Programa de Pós-Graduação em Direito, da Faculdade de Direito da Universidade de São Paulo, como exigência parcial para obtenção do título de Doutor em Direito, na área de concentração Direito Comercial, sob a orientação do Professor Doutor Newton Silveira.

UNIVERSIDADE DE SÃO PAULO

FACULDADE DE DIREITO

São Paulo-SP

2017 
Autorizo a reprodução e divulgação total ou parcial deste trabalho, por qualquer meio convencional ou eletrônico, para fins de estudo e pesquisa, desde que citada a fonte.

\section{Ficha Catalográfica \\ Faculdade de Direito da Universidade de São Paulo}

Santos Jr., Walter Godoy dos

O regime jurídico da proteção da forma na propriedade intelectual / Walter Godoy dos Santos Jr. - São Paulo: USP / Faculdade de Direito, 2017. $223 \mathrm{f}$. + anexos.

Orientador: Professor Doutor Newton Silveira

Tese (Doutorado), Universidade de São Paulo, USP, Programa de PósGraduação em Direito, Direito Comercial, 2017.

1. Propriedade Intelectual. 2. Direito Autoral. 3. Propriedade Industrial 4. Proteção da Forma. 5. Regime Jurídico. I. Silveira, Newton. II. Título. 
BANCA EXAMINADORA

Orientador: Professor Doutor Newton Silveira 


\section{DEDICATÓRIA}

Dedico este trabalho ao Professor Newton Silveira, meu mestre, orgulho das Arcadas e seguramente uma das mais respeitadas autoridades em matéria de propriedade intelectual no mundo. Estudioso incansável, culto e ao mesmo tempo erudito, é, para mim, um modelo a ser seguido na vida acadêmica e profissional. Ao homem dotado de humor refinado e de inteligência singular, minha sincera gratidão pelas oportunidades oferecidas como seu fiel aprendiz. Procurarei honrá-lo sempre e difundir as suas lições. 
"Le commencement de toutes choses, c'est l'amour. Le commencement de l'art, e'este le sentiment de la nature et la passion de la beauté. Mais il n'y a rien de plus rare que l'independence et l'originalité des impressions. Regarder simplement autour de soi est déjà une rareté insigne. La plupart des hommes passent à côté des plus belles choses sans les voir"*

"Todo homem possui, em maior ou menor grau, um potencial criativo. Ao exercer sua criatividade, acresce ao mundo coisas novas, cujo surgimento se deve a ele, a uma operação de caráter intelectual que resulta em uma nova realidade que vem enriquecer o mundo dos homens e ampliar seus limites. Fundamentalmente, o trabalho criativo é de um só tipo, seja no campo das ideias abstratas, das invenções ou das obras artísticas. O que se protege é o fruto dessa atividade, quando ela resulta em uma obra intelectual, ou seja, uma forma com unidade suficiente para ser reconhecida como ela mesma."**

"Toda forma, bela ou feia, tem sua causa, e, de todas os seres que existem, não há um que não seja como deve ser”***

*THORÉ, Théophile. Le salon de 1847; précédé d'une Lettre à Firmin Barrion. Paris: Alliance des Arts, 1847. p. 10.

**SILVEIRA, Newton. Propriedade intelectual. 5. ed. São Paulo: Manole, 2014. p. 12.

***DIDEROT, D. Ensaio sobre a pintura. Introd. e notas de Enid Abreu Dobransky. Campinas: Papirus, 1993. p. 27. 
SANTOS JR., Walter Godoy dos. O regime jurídico da proteção da forma na propriedade intelectual. 2017. 223f. Tese (Doutorado). Faculdade de Direito da Universidade de São Paulo, São Paulo, 2017.

\section{RESUMO}

O produto do esforço intelectual humano é transportado para o mundo dos fatos por meio de determinada forma, cujo conceito proposto abrange todos os recursos colocados à disposição do homem para trazer à realidade objetiva concepções técnicas ou estéticas suscetíveis de receber a tutela do Estado. Com efeito, a forma une o concreto ao abstrato, tornando possível a organização do caos interno, próprio dos sentimentos e pensamentos humanos, além de permitir que a obra seja devidamente comunicada e, a partir daí, que se estabeleçam relações jurídicas entre ela e o seu criador, bem como com terceiros. No campo do direito de autor, a forma se exterioriza para, em seguida, retornar ao mundo interior, despertando os sentidos humanos, fenômeno que não ocorre com as formas técnicas, concebidas para operar efeitos na realidade objetiva e produzir resultados no mundo exterior ao homem. Nesse contexto, a afirmação de que propriedade intelectual é forma oferece uma nova perspectiva para estudar-se o sistema de proteção ao esforço intelectual humano, permitindo que o intérprete da lei tenha um guia para a solução do paradoxo da acumulação de diversas proteções sobre um único objeto, que pode revelar-se ao mesmo tempo belo e útil. Note-se, a propósito, que o sistema da propriedade intelectual é composto por institutos cujas esferas de proteção não se interpenetram, cobrindo áreas estanques do engenho humano, cada qual com seus fundamentos e requisitos próprios, voltados para a consecução de uma determinada finalidade. Como é de conhecimento geral, a única maneira de apropriar-se, com exclusividade, de conteúdo técnico é por meio da obtenção de uma patente, que protege soluções para problemas do nosso cotidiano, considerada a realidade objetiva, externa ao homem. Fixadas essas premissas, pode-se estabelecer uma relação de subsidiariedade entre a propriedade industrial e o direito de autor, porquanto, embora os inventores possam também ser considerados autores no sentido amplo do termo (pais das invenções), não poderão retirar do direito autoral fundamento válido para proteger o conhecimento técnico. Quanto ao confronto entre o direito de autor e os demais institutos da propriedade industrial, como, por exemplo, as marcas e os desenhos industriais, cumpre salientar que a definição das respectivas esferas de proteção também não autoriza que se conclua pela sobreposição, mas sim por uma saudável harmonização de direitos. Assim compreendida a problemática subjacente ao tema proposto, percebe-se que há, em verdade, apenas um conflito aparente entre o direito de autor e a propriedade industrial, o que permite que convivam em harmonia, com vistas a coibir a concorrência desleal e o aproveitamento parasitário de esforços e investimentos alheios. Por fim, em casos fronteiriços, a aplicação do princípio da subsidiariedade tal como enunciado acima, dissolve eventuais obstáculos, com vistas a que os direitos de propriedade intelectual sirvam para impulsionar o País na direção do desenvolvimento econômico, tecnológico e cultural, considerado, em todos os casos, o interesse social.

Palavras-chave: Propriedade Intelectual; Direito Autoral; Propriedade Industrial; Proteção da forma; Regime Jurídico. 
SANTOS JR., Walter Godoy dos. The legal regime for protection of form within intellectual property. 2017. 223p. PhD Thesis, Faculty of Law, University of São Paulo, São Paulo, 2017.

\begin{abstract}
The result of human intellectual effort is manifested through forms. Therefore, the concept of form covers all resources at man's disposal to bring to reality technical and aesthetic concepts that may be protected by the State. Essentially, form unites the concrete to the abstract. This makes organizing and communicating ideas possible. From there, it is also possible to establish legal connections between a form and its creator, as well as with third parties. With respect to copyright, form is externalized and then returns to the inner world, awaking human senses - phenomena that do not occur within technical form. The latter is designed to bring about effects in the objective reality and produce results in the outside world. In this context, the claim that intellectual property is form offers a new perspective to study the intellectual property system. It also allows the interpreter of the law to have a guide to the resolution of the paradox regarding the accumulation of several protections on a single object, that can prove to be both beautiful and useful. It should be noted that the intellectual property system is composed of institutions whose spheres of protection do not interconnect. They cover different areas of human inventiveness, each of which has its own foundations and requirements to achieve a certain purpose. As it is generally known, the only way to appropriate, exclusively, technical content is by obtaining a patent. This protects solutions to problems of our daily life, considered the objective reality, external to man. Having established these premises, a relationship of subsidiarity between industrial property and copyright can be established. Although inventors can also be considered authors in the broad sense of the term, they are not allowed to use copyright to protect technical knowledge. Concerning the comparison between copyright and other industrial property institutes, such as trademarks and industrial designs, it should be pointed out that the definition of their respective spheres of protection does not legitimize the conclusion that it would be possible to accumulate protection on a single form, but rather it leads to the conclusion that, in fact, we have a harmonization of rights. By these means, the problem outlined in the proposed thesis is only an apparent conflict between copyright and industrial property, which allows them to coexist in harmony in order to avoid unfair competition and parasitism. Finally, it is important to outline that in forefront cases, the application of the principle of subsidiarity as set out above, dissolves any obstacles that intellectual property rights could present to economic, technological and cultural development of the country, that are always guided in accordance with the public interest.
\end{abstract}

Keywords: Intellectual Property; Copyright; Industrial Property; Protection of form; Legal Regime. 
SANTOS JR., Walter Godoy dos. Le régime juridique de la protection des formes dans la propriété intellectuelle. 2017. 223p. Thèse (Doctorat). Faculté de Droit, Université de São Paulo, 2017.

\section{RÉSUMÉ}

Le produit de l'effort intellectuel humain est transporté au monde des faits par une forme determinée dont le concept proposé contient toutes les ressources mises à disposition de l'homme pour apporter à la réalité objective les conceptions techniques ou esthétiques susceptibles de recevoir la tutelle de l'État. En effet, la forme unit le concret à l'abstrait en rendant possible l'organisation du chaos interne propre des sentiments et des pensées humains; elle permet encore que l'oeuvre soit dûment communiquée et à partir de cela, qu'on établisse des relations juridiques entre elle et son créateur ainsi qu'avec des tiers. Dans le domaine du Droit d'auteur la forme s'extériorise, pour retourner ensuite au monde intérieur, en réveillant les sens humains. C'est un phenomène qui n'arrive pas avec les formes techniques, conçues pour opérer des effets dans la réalité objective et pour produire des résultats dans le monde extérieur à l'homme. L'affirmation dans ce contexte que la propriété intellectuelle c'est de la forme, offre une nouvelle perspective pour qu'on étudie le système de protection à l'effort intellectuel humain en permettant que l'interprète de la loi ait un guide pour la solution du paradoxe de l'accumulation de plusieurs protections sur un seul objet qui peut se révéler au même temps beau et utile. On note à propos, que le système de propriété intellectuelle est composé par des instituts dont les sphères de protection ne s'interpenètrent pas, en s'étendant par des domaines étanches de l'engéniosité humaine, étant chacun d'eux avec ses fondements et ses conditions propres, tournés à la réussite d'un but précis. C'est de la connaissance générale que la seule manière de maîtriser avec exclusivité le contenu technique, c'est par l'obtention d'un brevet protégeant des solutions pour les problèmes de notre quotidien en envisageant la réalité objective extérieure à l'homme. Après avoir fixé ces prémisses, on peut établir une relation de subsidiarité entre la propriété industrielle et le Droit d'auteur. Cependant, même si les inventeurs peuvent être considerés des auteurs dans le sens large du mot (les pères des inventions), ils ne pourront pas enlever du Droit d'auteur le fondement valable pour protéger la connaissance technique. En ce qui concerne la confrontation entre le Droit d'auteur et les autres instituts de propriété industrielle comme par exemple les marques et les dessins industriels, on doit souligner que la définition des sphères concernant la protection n'autorise non plus qu'on conclut par la superposition, mais si par l'harmonisation saine de droits. Après la compréhension de la problématique subjacente au thème proposé, on remarque qu'il n'y a qu'un conflit apparent entre le Droit d'auteur et la propriété industrielle, ce qui permet de vivre ensemble en harmonie, afin de réprimer la concurrence déloyale et le profit parasitaire des efforts et des investissements d'autrui. Enfin, l'application du principe de subsidiarité dans des affaires limitrophes, tel que énoncé ci-dessus, dissout des obstacles éventuels pou que les droits de propriété intellectuelle servent à pousser le pays vers l'épanouissement économique, technologique et culturel, en envisageant dans toutes les affaires, l'intérêt social.

Mots-Clé: Propriété Intellectuelle; Droit d'auteur; Propriété Industrielle; Protection de la forme; Régime Juridique. 


\author{
ABREVIATURAS \\ ABNT - Associação Brasileira de Normas Técnicas \\ ABPI - Associação Brasileira da Propriedade Intelectual \\ ANVISA - Agência Nacional de Vigilância Sanitária \\ CADE - Conselho Administrativo de Defesa Econômica \\ CAMEX - Câmara de Comércio Exterior \\ CDB - Convenção sobre a Diversidade Biológica \\ CONMETRO - Conselho Nacional de Metrologia, Normalização e Qualidade Industrial \\ CUB - Convenção da União de Berna sobre o Direito de Autor \\ CUP - Convenção da União de Paris sobre a Propriedade Industrial \\ GAAT - General Agreement on Tariffs and Trade \\ INMETRO - Instituto Nacional de Metrologia, Qualidade e Tecnologia \\ INTA - International Trademark Association \\ OAMI - Oficina de la Unión Europea sobre Marcas, Dibujos y Modelos \\ OMC - Organização Mundial do Comércio \\ OMPI - Organização Mundial da Propriedade Intelectual \\ PCT - Patent Cooperation Treaty \\ RABPI - Revista da Associação Brasileira da Propriedade Intelectual \\ RDM - Revista de Direito Mercantil \\ SDE - Secretaria de Direito Econômico \\ TRIPS - Agreement on Trade-Related Aspects of Intellectual Property Rights \\ UPOV - União Internacional para a Proteção de Novas Variedades de Plantas \\ WIPO - World Intellectual Property Organization
}




\section{SUMÁRIO}

INTRODUÇÃO

1. REVOLUÇÃO INDUSTRIAL E REVOLUÇÃO FRANCESA

2. A PROPRIEDADE INTELECTUAL INTERNACIONAL .37

3. DIRETRIZES CONSTITUCIONAIS DA PROPRIEDADE INTELECTUAL .45

4. CONSIDERAÇÕES SOBRE A PROPRIEDADE INDUSTRIAL E O DIREITO CONCORRENCIAL

5. A NATUREZA JURÍDICA DOS DIREITOS INTELECTUAIS .95

6. A CORPORIFICAÇÃO DA CRIAÇÃO PELA FORMA 105

7. VISÃO MULTIDISCIPLINAR DA FORMA: AS SUAS VÁRIAS EXPRESSÕES.

8. CONCEITO E REQUISITOS LEGAIS PARA A PROTEÇÃO DA FORMA

9. CAMPOS DE PROTEÇÃO, LIMITAÇÕES E EXCEÇÕES: A ANÁLISE FRIA DA LEI

10. O CAMPO EXCLUSIVO DA TÉCNICA

11. A FORMA COMO LINGUAGEM ARTÍSTICA

12. RELAÇÃO DE SUBSIDIARIEDADE ENTRE DIREITO DE AUTOR E PROPRIEDADE INDUSTRIAL

13. ORIGINALIDADE E NOVIDADE

14. TEMPO DE PROTEÇÃO

15. ESTUDO DE CASO

15.1. Primeiro ato.

15.2. Segundo ato

15.3. Pareceres apresentados no caso

15.4. Comentários 
REFERÊNCIAS 209

ANEXOS 223

CONVENÇÃO DE BERNA PARA A PROTEÇÃO DAS OBRAS LITERÁRIAS E ARTÍSTICAS

TRATADO DE COOPERAÇÃO EM MATÉRIA DE PATENTES

CONVENÇÃO DE PARÍS PARA PROTEÇÃO DA PROPRIEDADE INDUSTRIAL

TRIPS 


\section{INTRODUÇÃO}

A propriedade intelectual ${ }^{1}$ é forma ${ }^{2}$. Com efeito, o produto do esforço intelectual humano ou aquilo que advém do subconsciente como inspiração (ato de arte), e que os italianos denominavam de "magia"3, é transportado para o mundo fenomênico por meio de determinada forma.

Nessa perspectiva, o conceito de forma ora proposto não se limita àquela noção enciclopédica comum de "aspecto físico próprio dos objetos e seres", nem se reduz à dimensão estritamente material, mas abarca todos os recursos colocados à disposição do homem para trazer ao mundo em que vivemos suas concepções técnicas ou estéticas, que, traduzidas em forma, seja em meio físico, seja em meio virtual, podem receber a tutela do Estado.

\footnotetext{
${ }^{1}$ Gama Cerqueira ensina que "[...] Ao conjunto desses direitos resultantes das concepções da inteligência e do trabalho intelectual, encarados principalmente sob o aspecto do proveito material que deles pode resultar, costuma-se dar a denominação genérica de propriedade intelectual [...]" CERQUEIRA, João da Gama. Tratado da propriedade industrial. 1. ed. Rio de Janeiro: Revista Forense, 1956. v. 1, t. 1, p. 68-69. Vide, ainda, outro trecho do referido tratadista no sentido de que a "propriedade industrial, que pode ser definida como o conjunto dos institutos jurídicos que visam garantir os direitos de autor sobre as produções intelectuais do domínio da indústria e assegurar a lealdade da concorrência comercial e industrial." A propriedade industrial poderia também ser definida, de modo mais geral, como "o conjunto de normas legais e princípios jurídicos de proteção à atividade do trabalho, no campo das indústrias, e a seus resultados econômicos, abrangendo, assim, a proteção das produções intelectuais do domínio industrial (invenções, modelos de utilidade e desenhos e modelos industriais) e toda a matéria relativa à repressão da concorrência desleal, inclusive as marcas, o nome comercial, as indicações de origem dos produtos, etc. Preferimos, porém, a primeira definição por ser mais restrita, particularizando melhor o objeto da propriedade industrial.” Id. Ibid., p. 72-73. Poder-se-ia dizer, em síntese, que a expressão Propriedade Industrial engloba assuntos referentes a marcas, patentes (de invenção e de modelo de utilidade), desenhos industriais, assim como contratos de licença de uso ou exploração de tais direitos e contratos de transferência ou fornecimento de tecnologia ou know-how e de franquia. Quando a isto se somam os direitos autorais, fala-se em Propriedade Intelectual, categoria mais ampla, que abarca a Propriedade Industrial.

${ }^{2}$ Para Rudolf Arnheim: "forma é a configuração visível do conteúdo". ARNHEIM, Rudolf. Arte e percepção visual. São Paulo: Pioneira, 1997. p. 89.

${ }^{3}$ Para Silveira "[...] o esforço, a inspiração, o impulso ou mesmo o que os italianos chamavam de "magia" para chegar a algo perceptível aos sentidos." SILVEIRA, Newton. Abuso de patentes. p. 8. Disponível em: $<$ http://www.lex-net.com/new/wp-content/uploads/2014/10/50-Abuso-de-patentes.pdf $>$. E mais, "Essa concepção unitária da arte e da técnica já se podia vislumbrar na criação de Leonardo Da Vinci, para quem a atividade artística e a atividade científica nasciam de uma inspiração única, nutriam-se sem cessar uma da outra, e as conquistas de uma influenciavam o desenvolvimento da outra." SILVEIRA, Newton. Direito de autor no design. 2. ed. São Paulo: Saraiva, 2012. p. 44-45. De acordo com Regis de Oliveira: "A inspiração não vem quando eles [os artistas] querem ou é buscada. Simplesmente vem. Sem avisos ou receios. Aparece quando menos se espera. Explode na mente do artista. Brota como água da montanha. As fontes são as mais vitais." OLIVEIRA, Régis Fernandes. Direito e arte. São Paulo: Malheiros Ed., 2017. p. 54.
} 
Tem-se, portanto, que a forma corporifica tais abstrações ${ }^{4}$ no mundo real, é o vínculo que une o concreto ao abstrato, tornando possível a organização do caos interno, próprio dos sentimentos e pensamentos humanos, além de permitir que a obra ${ }^{5}$ (técnica ou simplesmente estética) seja devidamente comunicada e, a partir daí, que se estabeleçam relações jurídicas entre a forma e seu criador ${ }^{6}$, bem como entre esta e terceiros.

A propósito das etapas percorridas desde a inspiração até se chegar à obra de arte, Walter Moraes ressalta o seguinte:

"O belo objetivo descobre-se na natureza a cada passo. Mas os homens aprenderam desde cedo a criar as condições capazes de ativar a emoção estética, ou seja, alcançaram abstrair, em momentos de alta intuição (ou inspiração), que são momentos de emoção estética absoluta, condições objetivas suprarreais da àisthesis, supostamente acessíveis à análise racional, e lograram impregnar delas suportes naturais. Tal resultado é a obra de arte. Tal operação, que é em si estética, pois é carga emocional estética espontânea do artista que a alimenta e lhe dá consistência, o ato de arte, que não pode submeter-se a regras de procedimento na sua primeira fase (a da concepção), mas deve, na segunda fase (a execução), obedecer a certos preceitos, cumprir determinadas condições, necessárias a tornar a obra suscetível de perfeita comunicação: pois aqui não basta a intelecção estética, impondo-se habilidades específicas que conduzam a criação ao objetivo colimado que é a emoção estética."7

Nesse sentido, Cláudio Roberto Barbosa assevera que o formato juridicamente protegível pela propriedade intelectual é a representação da ideia e não a ideia em si, seja

\footnotetext{
4‘'Ideia e forma são necessárias uma à outra. A ideia sem a forma não passaria de um magma de imagens confusas e incoerentes, uma excentricidade; a forma sem a ideia seria um envoltório vazio, um vácuo de pensamento, uma fonte seca. A forma alimenta-se nas pastagens da ideia; a ideia precisa de forma para se converter em matéria e vida." CLARET, Jacques. A idéia e a forma: problemática e dinâmica da linguagem. Rio de Janeiro: Zahar, 1980. p. 7. Mais adiante esclarece que: "Os esquimós, por exemplo, percebem 30 variedades distintas de neve, e não a neve em geral; não porque tenham arbitrariamente resolvido percebê-las, mas porque são incapazes de perceber de outro modo a realidade. A atividade prática marcou a língua, e a experiência social fixada pela linguagem domina o funcionamento do pensamento". Id. Ibid., p. 106.

${ }^{5}$ A utilização do termo "obra" abarca as criações técnicas, protegidas pelos institutos da Propriedade Industrial e estéticas, que recebem a proteção advinda do Direito de Autor.

${ }^{6}$ Cláudio Roberto Barbosa ensina que: “A utilização do termo 'criador' em substituição aos tradicionais termos 'inventor', 'autor', etc. é proposital a fim de evitar as confusões decorrentes da especificidade das diferentes 'criações' de cada um destes. Assim, o 'inventor' é o 'criador' da 'invenção', o 'autor' é o 'criador' da 'obra', o ‘intérprete' é o ‘criador' da 'interpretação'”. BARBOSA, Cláudio Roberto. A relação entre informação, propriedade intelectual, jurisdição e direito internacional. 2001. Dissertação (Mestrado) - Programa de Pós-Graduação em Direito, da Faculdade de Direito da Universidade de São Paulo, São Paulo, 2001.

${ }^{7}$ MORAES, Walter. Arte. In: FRANÇA, Rubens Limongi (Org.). Enciclopédia Saraiva do Direito. São Paulo: Saraiva, 1977. v. 8, p. 142. Em seu "Ensaios sobre a pintura", Diderot afirma o seguinte: "Sou pouco versado nas leis sobre a maneira de drapejar as figuras; ela é inteiramente poesia quanto à invenção, inteiramente rigor quanto à execução". DIDEROT, D. Ensaio sobre a pintura, cit., p. 92.
} 
na forma de sinal distintivo (marca), seja na forma de um quadro reivindicatório (patente), seja na obra artística. ${ }^{8}$

Dessa maneira, o direito consegue captar e proteger apenas aquilo que possa adotar determinada forma, uma vez que concepções puramente abstratas, como um pensamento, uma ideia ou uma determinada sensação não são suscetíveis de tutela, porquanto não são considerados objeto de direito. ${ }^{9}$

Nesse diapasão, também é importante relembrar a lição de Newton Silveira no sentido de que o processo mental das criações é unitário, ou seja, "o mesmo esforço que deu origem à indústria (satisfação das necessidades materiais) criou as artes para a satisfação das necessidades espirituais do ser humano." 10

Assim, aperfeiçoado o ciclo mental referido acima, vêm à lume esculturas, pinturas, partituras, letras e algarismos, fórmulas químicas, marcas, desenhos industriais, livros, procedimentos descritos em textos, bem como uma infinidade de outras manifestações intelectuais, que são originalmente concebidas de maneira abstrata e, posteriormente, carreadas para o mundo em que vivemos por meio de suportes, materiais ou não, que, invariavelmente, adotam determinada forma.

É o que Pontes de Miranda denomina de "ideia enformada", verbis:

"[...] ninguém pode pretender que se lhe proteja a idéia, se não a enformou. À mesma idéia podem-se dar diferentes formas. Protege-se a idéia enformada, a forma que primeiro se obteve. Daí poder haver tradução e adaptação, com proteção à parte, mas de certo modo ligada à obra original. A idéia, em senso lato, é que é incorpóreo." 11

\footnotetext{
${ }^{8}$ Segundo o autor: "Cabe desenvolver melhor esta noção. Para a propriedade intelectual o objeto a ser comunicado é a idéia, o conceito criado, o qual não pode ser juridicamente protegido dentro do sistema da propriedade intelectual que exige a transcrição da informação em um meio tangível. A representação da idéia, portanto, é o formato juridicamente protegível pelo Direito, seja um sinal distintivo, seja um quadro reivindicatório de uma patente de invenção, seja uma obra artística. Todavia o valor está associado à informação e é a dificuldade de transposição deste valor à proteção jurídica da representação que também acarreta perdas e, conseqüentemente, custos sociais". BARBOSA, Cláudio Roberto. Propriedade intelectual enquanto informação. Uma perspectiva de "Law and Economics". California Digital Library. University of California, 2007. p. 14. Disponível em: <https://cloudfront.escholarship.org/dist/prd/content/qt9q80d5w8/qt9q80d5w8.pdf>.

${ }^{9}$ De acordo com os ensinamentos de Darcy Bessone: "[...] o Direito Autoral nasce de uma ideia, de uma abstração intelectual, de um sentimento forjado sócio-culturalmente na pessoa, portanto, uma propriedade incorpórea e, também recebe o "status" de propriedade corpórea no instante em que essa ideia, essa abstração, esse sentimento, materializa-se num bem corpóreo". BESSONE, Darcy. Direitos reais. São Paulo: Saraiva, 1988. p. 499.

${ }^{10}$ Newton Silveira ressalta "Os célebres textos de H. Poincaré sobre seus processos de invenção no campo da matemática revelam "processos que são, no fundo, análogos ao da invenção artística”. SILVEIRA, Newton. Direito de autor no design, cit., p. 29.

${ }^{11}$ MIRANDA, Francisco Cavalcanti Pontes de. Tratado de direito privado: parte especial. 3. ed. Rio de Janeiro: Borsoi, 1972. t. 17, p. 102.
} 
Note-se, a propósito, que, no campo do direito de autor, a forma se exterioriza (vem ao mundo fenomênico) para, em seguida, retornar ao mundo interior ${ }^{12}$, que é o seu habitat natural, despertando os nossos sentidos ${ }^{13}$, o que não ocorre com as formas técnicas concebidas para operar efeitos na realidade objetiva e produzir resultados no mundo exterior.

Nesse contexto e na esteira do aduzido por Tullio Ascarelli ${ }^{14}$, é importante salientar que a obra autoral se expressa por meio de uma determinada forma ${ }^{15}$, entendida como

12Para Silveira "A forma criada pelo artista pode ser emprestada pelo mundo exterior, mas é animada pelo
sentimento que inspira ao homem interior. "A natureza e a humanidade são a um tempo, e
indissoluvelmente, o objeto e o tema de todas as artes, assim como da ciência e da indústria. A arte
manifesta os fenômenos da vida universal, a ciência explica-os e a Indústria adapta-os às necessidades do
homem. A arte propõe, a ciência expõe e a indústria dispõe"”. Thoré, "Salão de 1861", publicado no "Le
Temps". SILVEIRA, Newton. Direito de autor no design, cit., p. 31-32.
${ }^{13}$ Para Edmund Burke: "que eu saiba, os poderes naturais do homem que estabelecem ligações com os
objetos externos são os Sentidos, a imaginação e o Juízo. Falemos primeiro sobre os sentidos. Acreditamos
e devemos supor que a conformação dos órgãos dos homens são quase ou completamente as mesmas em
todos; da mesma forma, a maneira de perceber os objetos externos é a mesma, ou com pouca diferença, em
todos os homens. [...] Mas, tendo em vista a existência de muito pouca dúvida de que os corpos apresentam
imagens semelhantes a toda a espécie, deve-se necessariamente ser admitido que os prazeres e das dores
que cada objeto incita em um homem devem causar o mesmo efeito em toda a humanidade, operando de
forma natural, simples e apenas por meio de seus próprios poderes; pois, se negássemos isso, precisaríamos
imaginar que a mesma causa operando da mesma forma e em indivíduos da mesma espécie, produziria
efeitos diferentes, o que seria um grande absurdo" In BURKE, Edmund. Investigação filosófica sobre a
origem das nossas ideias do sublime e da beleza. 1. ed. São Paulo: Edipro, 2016. p. 31 .

${ }^{14}$ Tullio Ascarelli, em seu Teoría de la Concurrencia y de los Bienes Inmateriales, cuida, mais sistematicamente, dos limites recíprocos entre a tutela das obras literárias e artísticas e a das obras técnicas. "En los inventos la aportación creadora concierne al mundo de la técnica y consiste en un descubrimiento que hace posible el disfrute de las fuerzas de la naturaleza a efectos de satisfacer las necesidades humanas, consiguiendo la solución de un problema técnico, un resultado industrial". ASCARELLI, Tullio. Teoria de la concurrencia y de los bienes inmateriales. Trad. ao espanhol de E. Verdera; L. Suarez-Llanos. Barcelona: Bosch Casa Editorial, 1970. p. 321.

"La técnica representa, así, el dominio del hombre sobre la naturaleza y desde la lejanísima invención de la rueda hasta el momento presente, el camino de la civilización ha sido también un camino de la técnica y la máquina ha sido instrumento de bienestar y de libertad". Id. Ibid., p. 487 "Y es por eso por lo que, como se ha observado varias veces, el reconocimiento de la protección a toda obra del ingenio no implica (y ciertamente no implica en nuestro ordenamiento positivo) la protección de toda creación intelectual; el reconocimiento de la diferencia, precisamente frente al interés público, entre la protección de las obras del ingenio y la de los inventos industriales, ciertamente no puede llevar a desconocer que también la protección de las obras del ingenio tiene su justificación última en un interés público y no se sitúa como una exigencia anterior a la ley". Id. Ibid., p. 628 "En efecto, la "materia" es ajena a la protección no sólo cuando ha sido extraída de la experiencia común, sino también cuando ha sido fruto personal de las investigaciones, del pensamiento del autor, precisamente porque la creación artística no recae sobre el asunto sino sobre la expresión y es en esta expresión donde se manifiesta su individualidad". Id. Ibid., p. 636.

"Desde este punto de vista se perciben conjuntamente las analogías y las diferencias con los inventos industriales (que podemos decir que conciernen al dominio de lo útil), en los que también se dan unas creaciones intelectuales que también provienen de un autor (que en tal caso llamamos inventor) y que poseen una individualidad identificable al margen de toda referencia a un objeto material, pero que se concretan, precisamente, en un resultado inventivo, por lo que la exclusiva se proyecta sobre la utilización de dicho resultado y no sobre la reproducción de la expresión a través de la cual se ha formulado". Id. Ibid., p. 638-639.

15“ $\mathrm{O}$ Direito de Autor busca fomentar a criatividade e a liberdade das formas, enquanto as patentes estão relacionadas a aspectos técnicos e restrição de forma. Daí serem irreconciliáveis estas duas espécies de direitos, que protegem coisas distintas. Do ponto de vista do Direito de Autor, também não se pode sustentar que existiria proteção autoral sobre criações técnicas em relação a objetos cujas formas sejam ditadas essencialmente por suas funções. Isto porque, por mais artística que possa ser uma configuração, se sua forma possuir efeito técnico e não for possível dissociá-lo do seu caráter industrial, não se deve falar 
linguagem ${ }^{16}$ necessária para penetrar o nosso mundo interior. Já na seara da propriedade industrial, as formas vêm ao mundo e nele permanecem para solucionar um dado problema no domínio da técnica, mostrando-se úteis ao ser humano. ${ }^{17}$

Independentemente de ser a forma o objeto mesmo da proteção ou de ter outro significado (representar uma ideia, uma concepção), do ponto de vista estritamente jurídico, verificamos que não há diferenças entre a relação jurídica ${ }^{18}$ que se estabelece

em direito de Autor sobre tal criação: Assim, apesar de a lei não mais ser expressa no sentido de excluir da proteção autoral a forma ditada essencialmente pela função, entende-se que, no contexto maior da proteção da propriedade intelectual, deve-se evitar a proteção por direito autoral da forma cuja originalidade da obra não possa dissociar-se do caráter industrial do objeto". JABUR, Wilson Pinheiro. Interface entre propriedade industrial e direito do autor. In: SANTOS, Manoel Joaquim Pereira dos; JABUR, Wilson Pinheiro (Orgs.). Propriedade intelectual: direito autoral. São Paulo: Saraiva, 2014. p. 230.

${ }^{16}$ Acerca deste assunto específico, Vide a pedagógica explicação apresentada por Newton Silveira: "[...] a distinção formulada por Ascarelli no sentido de que, no caso das artes plásticas, a "forma" concerne à "linguagem", à comunicação, enquanto que no caso dos modelos industriais, a forma corresponde à coisa em si. Em outras palavras, quando a forma de um produto industrial se reduz a essa finalidade, não há dissociação entre o caráter industrial e o seu valor artístico, ou seja, não há valor artístico, o qual somente surge quando tal forma corresponde a uma linguagem, revelando o cunho pessoal do autor, o que equivaleria a dizer que a forma possui caráter expressivo. Como se verifica, trata-se, exatamente, do mesmo requisito que exige a lei em relação à fotografia, sendo valor artístico sinônimo de caráter expressivo." SILVEIRA, Newton. Estudos e pareceres de propriedade intelectual. Organização e Seleção de Wilson Silveira. Rio de Janeiro: Lumen Juris, 2008. p. 315. Disponível em: <https://ibpieuropa.org/book/silveiranewton-estudos-e-pareceres $>$. Sobre a fotografia, vide Jean Lacoste para quem: “[...] a fotografia não é um registro passivo da realidade percebida: ela fixa limites ao campo visual, fixa um instante da visão monocular, reproduz as cores e os valores segundo uma gama bastante limitada de cinzento". LACOSTE, Jean. A filosofia da arte. Rio de Janeiro: Zahar, 2011. p. 70.

${ }^{17}$ Por outras palavras, esclarece o Professor Silveira que: "O direito de autor, assim como o direito do inventor, tem por objeto uma determinada concepção de seu criador. No direito de autor tal concepção se expressa através de uma determinada forma (que não se confunde com o objeto material que lhe serve de suporte). Já o direito do inventor consiste na própria ideia de solução técnica, o que torna necessário, também, o exagerado formalismo a que fizemos menção acima. Assim, desde que a invenção não se reduza à determinada forma de materialização da invenção, é preciso determinar seu âmbito no campo das ideias, restringindo o seu alcance àquilo que o inventor declara ter inventado, reivindicando a exclusividade. $\mathrm{Na}$ prática, tal se realiza através dos pontos característicos da invenção, ou reivindicações, que constam do pedido de patente e em relação aos quais será feito o exame de novidade e de mérito. O Estado, através de seus órgãos competentes (entre nós. é o Instituto Nacional da Propriedade Industrial), deverá proceder ao exame das reivindicações, eventualmente determinando a redução de seu alcance. Do título do privilégio concedido pelo Estado - a patente - constarão as reivindicações aprovadas, que, na forma da lei caracterizam as particularidades do invento, estabelecendo e delimitando os direitos do inventor. Já nas obras artísticas, as quais têm por objeto determinada forma, o alcance do direito do autor é determinado pela própria obra objetivada no suporte material. Dessa forma, num caso ou em outro, o objeto do direito é uma coisa puramente intelectual, de natureza incorpórea ou imaterial, o que foi acentuado por Picard ao conceber sua teoria dos direitos intelectuais." SILVEIRA, Newton. Direito de autor no design, cit., p. 8384. No mesmo sentido, esclarece Oliveira Ascensão que "O objeto do direito de autor é uma obra, a obra intelectual. Mas a obra intelectual é um bem incorpóreo. Não se confunde com o suporte em que porventura incarne nem precisa dele para existir. Um repentista produz uma obra e tem direito de autor, mesmo que não tenha fixação de espécie nenhuma. A questão é de prova, que se não confunde com a da determinação da obra." ASCENSÃO, José de Oliveira. O direito autoral numa perspectiva de reforma. In: WACHOWICZ, Marcos; SANTOS, Manuel Joaquim Pereira dos (Orgs.). Estudos de direito de autor: a revisão da Lei de Direitos Autorais. Anais do III Congresso de Direito de Autor e Interesse Público. [Recurso eletrônico]. Florianópolis: Fundação Boiteux, 2010. p. 35. Disponível em: $<$ http://www.gedai.com.br/sites/default/files/publicacoes/livro_mw_estudodireitoautor.pdf $>$.

18“O que importa saber, portanto, é se a relação jurídica entre o autor e a criação intelectual é idêntica à que existe entre o proprietário e a coisa corpórea que constitui objeto de seu direito, pois é a natureza dessa 
entre o sujeito (criador) e o objeto do direito (obra), porquanto está devidamente assentado na doutrina e na jurisprudência que a natureza jurídica de tais vínculos jurídicos é tipicamente de propriedade, verdadeiro amálgama do sistema de proteção ao esforço intelectual humano.

Registre-se, portanto, que a unidade do sistema ${ }^{19}$ inicia-se pelo processo mental das criações, estende-se para a sua exteriorização e encontra eco no ordenamento jurídico, que classifica a relação jurídica estabelecida entre o criador e a obra como de direito de propriedade.

Da mesma maneira, em termos de princípios, a propriedade intelectual orienta-se, basicamente, pela repressão à concorrência desleal, que constitui, nas palavras de Gama Cerqueira, o fundamento e a razão de suas leis, in verbis:

"[...] a propriedade industrial constitui um sistema jurídico, um todo orgânico,
como se costuma dizer, subordinando-se os seus diferentes institutos aos mesmos
princípios gerais, que podem variar em suas aplicações particulares, mas que não
perdem a sua unidade fundamental", ressaltando que "todo o edifício da
propriedade industrial, como, aliás, o da propriedade literária, científica e
artística, repousa no princípio ético da repressão da concorrência desleal, que
constitui o fundamento e a razão de suas leis, podendo-se mesmo dizer que em
nenhum outro ramo da ciência jurídica se manifesta de modo mais eloquente o
fundamento moral do Direito."

relação que caracteriza os direitos reais, em geral, e o de propriedade, em particular, constituindo, ainda, o critério de distinção entre os direitos reais e os de obrigações" CERQUEIRA, João da Gama. O direito de autor como direito de propriedade. Revista dos Tribunais, São Paulo, ano 47, v. 270, p. 22, abr. 1958. "Resumindo tudo quanto nesta parte ficou exposto, podemos dizer que o direito de autor e de inventor é um direito privado patrimonial, de caráter real, constituindo uma propriedade móvel, em regra temporária e resolúvel, que tem por objeto uma coisa ou bem imaterial, denomina-se, por isto, propriedade imaterial, para indicar a natureza de seu objeto". Id. Ibid., p. 25.

19“"Nessa medida, devem ser relembrados os ensinamentos de Geraldo Ataliba: "O sistema jurídico (...) tem profunda harmonia interna. Esta se estabelece mediante uma hierarquia segundo a qual algumas normas descansam em outras, as quais, por sua vez, repousam em princípios que, de seu lado, se assentam em outros princípios mais importantes. Dessa hierarquia decorre que os princípios maiores fixam as diretrizes gerais do sistema e subordinam os princípios menores. Estes subordinam certas regras que, à sua vez, submetem outras". ATALIBA, Geraldo. Sistema constitucional tributário brasileiro. 1. ed. São Paulo: Revista dos Tribunais, 1968. p. 33.

${ }^{20}$ CERQUEIRA, João da Gama. Tratado da propriedade industrial. 1. ed., cit., v. 1, t. 1, p. 8-9. Alf Ross adverte que "a tarefa da ciência do direito é expor o direito vigente. Esta tarefa requer que a exposição possua um sistema, que a ordem e a conexão nas quais o material é apresentado sejam dispostos segundo um plano definido. O ordenamento sistemático é valioso, primeiramente, por razões práticas: é essencial por questão de clareza, a título de meio de entrever o caminho no complexo tema do direito (...) O sistema também serve de fundamento para uma divisão do estudo do direito que, pelo menos na atualidade, é indispensável. A organização sistemática é valiosa, também, por razões teóricas. Se baseada em critérios relevantes, ajuda o estudioso a analisar o material jurídico, revela problemas e exibe semelhanças e diferenças ocultas". ROSS, Alf. Direito e justiça. Tradução e notas de Edson Bini. 1. ed. Bauru-SP: Edipro, 2000. p. 239. Hans Kelsen debruçou-se sobre a questão, desenvolvendo sua teoria sobre o sistema jurídico. Em sua opinião, o ordenamento jurídico seria composto como uma ordem escalonada de normas, dispostas hierarquicamente na forma de uma pirâmide. Na base da pirâmide estariam as normas individuais e concretas, que encontrariam seu fundamento de validade em uma norma de hierarquia superior, de caráter geral e abstrato, e assim sucessivamente, até nos depararmos, no topo da estrutura, com a constituição, que seria a norma posta de maior nível hierárquico dentro de um sistema jurídico. KELSEN, Hans. Teoria pura do direito. Trad. João Batista Machado. 6. ed. São Paulo: Martins Fontes, 1998. 
Cumpre salientar também que os direitos de propriedade intelectual podem ser agregados pela sua finalidade, porquanto devem ser concedidos e exercidos consoante o interesse comum, com vistas a que sirvam de vetores para o desenvolvimento cultural, tecnológico e econômico do País, notadamente diante do disposto no art. $5^{\circ}$, XXIX, da Constituição Federal, e não como ferramentas para proteção de interesses egoísticos de seus titulares. ${ }^{21}$

Ainda na trilha da unidade deste ramo do direito, é preciso enfatizar que a propriedade intelectual é composta por institutos cujas esferas de proteção não se interpenetram, cobrindo áreas estanques do engenho humano, cada qual com seus fundamentos e requisitos próprios, voltados para a consecução de uma determinada finalidade, cumprindo-se salientar que o direito de propriedade inunda todos estes compartimentos, neles deixando seus fragmentos.

Nesse sentido, o direito de autor e a propriedade industrial são complementares, porque o direito autoral não oferece proteção às soluções que se inserem no campo da técnica, principalmente quando a forma é necessária para obter-se um determinado resultado ou efeito técnico no mundo fenomênico. Da mesma maneira, a propriedade industrial não deve dar guarida para as obras puramente artísticas, mostrando-se refratária ao que advém exclusivamente do campo estético e que não tenha aplicação industrial.

Isso posto, deve-se reconhecer que a infinidade de formas produzidas nos mais variados campos do conhecimento humano não deturpa a unidade de sua concepção, que é também preservada pelo sistema de proteção dos direitos da "mente", na linguagem de Bobbio $^{22}$, por meio da acomodação das criações dentro do vasto cardápio de direitos exclusivos oferecido pelo sistema da propriedade intelectual.

\footnotetext{
${ }^{21}$ Para Migue Reale; "O Direito é uma proporção real e pessoal, de homem para homem..." parece, à primeira vista, uma expressão redundante: pessoal, de homem para homem. Se é pessoal, por que dizer de homem para homem? É que, para Dante, o Direito tutela as coisas somente em razão dos homens: a relação jurídica conclui-se entre pessoas, não entre homens e coisas, mas é "real" quando tem uma coisa (res) como seu objeto". REALE, Miguel. Lições preliminares do direito. 24. ed. São Paulo: Saraiva, 1998. p. 56 "Não pensem que há na ordem jurídica a preocupação de levantar paredes em torno da atividade individual. $\mathrm{O}$ ideal é que cada homem possa realizar os seus fins da maneira mais ampla, mas é intuitivo que não poderia coexistir o arbítrio de cada um como o dos demais sem uma delimitação harmônica das liberdades, consoante clássico ensinamento de Kant. Desse modo, o Direito delimita para libertar: quando limita, liberta". Id. Ibid., p. 56.

${ }^{22}$ Vide, nesse sentido, a citação de Pedro Marcos Nunes Barbosa: "Bobbio faz pertinente citação de Thomas Paine: São direitos naturais os que cabem ao homem em virtude de sua existência. A esse gênero pertencem a todos os direitos intelectuais, ou direitos da mente." BARBOSA, Pedro Marcos Nunes. Direito civil da propriedade intelectual. 3. ed. Rio de Janeiro: Lumem Juris, 2016. p. 45.
} 
A quebra da unidade desse sistema - do ponto de vista conceitual - ocorre nas hipóteses em que a forma transborda o caráter estritamente técnico (utilidade), mostrandose também estética (bela) ${ }^{23}$ ou, de outro lado, extravasa os limites estritos do direito de autor (considerado o caráter puramente artístico), mostrando-se também útil.

Nessas hipóteses, pode, em tese, ocorrer uma acumulação de proteções sobre a mesma forma pela incidência de mais de um instituto do sistema da propriedade intelectual, com o potencial de produzir efeitos colaterais, sobretudo no campo da concorrência, ${ }^{24}$ ao proporcionar a um agente de mercado uma vantagem desmesurada.

Para estudar esse fenômeno, iremos, inicialmente, revisitar os fatos históricos que deram origem ao sistema da propriedade intelectual, evidentemente, com o enfoque sobre o tema proposto, sem descuidar do fenômeno mais recente de internacionalização deste sistema pelos Tratados de Paris, Berna e pelo TRIPS (Agreement on Trade-Related Aspects of Intellectual Property Rights).

A seguir, procuraremos estudar as diretrizes constitucionais do sistema da propriedade intelectual, bem como a relação entre este ramo do direito e o direito da concorrência. Resgataremos, outrossim, as discussões a respeito da natureza jurídica da proteção conferida aos chamados "bens imateriais", não com o propósito de tentar validar doutrina já superada, que procurava classificar a natureza jurídica do objeto do direito em

\footnotetext{
${ }^{23}$ Para Regis de Oliveira: “A obra de arte pressupõe uma criação humana. Não se dá a mesma emoção diante da natureza. A beleza de uma paisagem, do pôr do sol ou de lavas que escorrem de uma erupção vulcânica despertam outro tipo de admiração. Apreciamos as maravilhas naturais. Outra coisa é o sentimento estético de uma obra criada pelo homem. [...] Toda emoção estética positiva gera o sentimento de beleza. A música, a tela, a escultura, etc. A mulher gera o sentimento da beleza estética sensual. Não é o mesmo afeto diante da tela de Bosch. Há críticos que sustentam que há quadros que são simplesmente descritivos de alguma realidade. Não concordamos com isso. Quadros que retratam fatos históricos igualmente são obras de arte, porque despertam, ao lado do fato, a emoção estética de quem os vê. O sentimento estético não se confunde com o moral. Obras que passam identificar sentimentos de compaixão, ódio, amor etc. igualmente são obras de arte. Nunca a obra sugere emoção falsa. É sempre emoção e nunca falsa. A arte igualmente pode transmitir informações e ideias. Nem por outro motivo é que o Estado sempre busca interferir. A arte também pode ser utilizada como instrumento de dominação. [...] A profissão pode mudar a percepção. $\mathrm{O}$ grau de amadurecimento e cultura. [...] as emoções afetam cada um de uma forma. Não se podem padronizar os sentimentos". OLIVEIRA, Régis Fernandes. Direito e arte, cit., p. 21. Arte, como disse, é fruto da emoção estética universal e eterna. São criações de todos os tempos, mas continuam produzindo o êxtase estético. Isso é arte. [...] São sentimentos que impulsionam o criador a se emocionar diante delas. Mesmo tristes. Mas, são afetos que ultrapassam a razão. Id. Ibid., p. 22.

${ }^{24}$ Paula Forgioni adverte que: "O direito concorrencial é um ramo do direito econômico e, como tal, corporifica "técnica de que lança mão o Estado contemporâneo para implementação de políticas públicas, mediante a repressão ao abuso do poder econômico e a tutela da livre concorrência". De acordo com a Constituição do Brasil, essa técnica é instrumental, devendo ser concebida como ferramenta para o alcance dos fins postos pelos arts. $1^{\circ}$ e $3^{\circ}$ da Constituição". E mais: "O direito concorrencial representa uma combinação única de questões jurídicas econômicas e políticas, que requerem tempo para serem entendidas, assimiladas e aplicadas de maneira eficiente". FORGIONI, Paula A. Direito concorrencial e restrições verticais. São Paulo: Revista dos Tribunais, 2007. p. 17.
} 
detrimento da relação que estabelece com o sujeito, mas, sim, de aproveitar aquelas ricas lições com outro objetivo, qual seja, o de auxiliar o desate do paradoxo em apreço, com vistas a preservar a unidade do sistema de proteção das criações intelectuais e, simultaneamente, a instituição concorrência.

Note-se, dessa perspectiva, que se for possível equacionar a referida questão dentro do próprio sistema de proteção da propriedade intelectual - internamente -, nenhum efeito indesejado ou contrário aos fundamentos que lhe servem de justificativa seria, em princípio, produzido. Por outras palavras, a manutenção da unidade do sistema, tal como concebido a partir da Revolução Francesa ${ }^{25}$, com o devido resguardo de seus princípios e de suas finalidades, vinculadas a estímulos premiais e à proibição da concorrência desleal, pode dissipar conflitos aparentes, evitando-se verdadeira autofagia.

A partir de tais constatações, procuraremos definir os campos de proteção da técnica e da estética e estabelecer uma relação de subsidiariedade entre o direito de autor e a propriedade industrial. Ora, se considerarmos que todas as criações intelectuais pertencem ao campo do direito de autor, exceto as do campo da técnica, temos que tudo aquilo que não for suscetível de proteção no campo da técnica ou o que escapar da esfera de proteção por ele conferido, pode passar aos domínios do direito autoral.

Assim, tudo o que disser respeito exclusivamente à técnica não pode ser capturado pelo direito de autor, que oferece proteção mais genérica e sem todos aqueles requisitos necessários para se obter uma patente (vide o disposto nos arts. 11 e seguintes da Lei 9.279/1996).

Desse modo, respeitada a relação de subsidiariedade entre o direito de autor e a propriedade industrial e consideradas as suas respectivas esferas de proteção, poderemos verificar se o conflito acima apontado é real ou aparente e, bem assim, se seria possível estabelecer-se uma saudável relação de complementariedade entre estas tutelas legais.

\footnotetext{
${ }^{25}$ As teorias democráticas, ou da soberania popular, apresentam três fases sucessivas, nitidamente distintas. Na primeira, aparece como titular da soberania o próprio povo, como massa amorfa, situado fora do Estado. Numa segunda fase, que adquire seu ponto de consolidação na Revolução Francesa, influindo sobre as concepções políticas do século XIX e início do século XX, a titularidade é atribuída à nação, que é o povo concebido numa ordem integrante. Por último, chega-se à afirmação de que o titular da soberania é o Estado, o que começaria a ser aceito na segunda metade do século passado e ganharia grande prestígio no século atual. Se a soberania é um direito, seu titular só pode ser uma pessoa jurídica. Ora, o povo, mesmo concebido como nação, não tem personalidade jurídica. Mas, como ele participa do Estado e é o elemento formador da vontade deste, a atribuição da titularidade da soberania ao Estado atende às exigências jurídicas, ao mesmo tempo em que preserva o fundamento democrático. Essa última concepção é designada por MORTATI como legitimista, pois a legitimação do soberano, que equivale ao nascimento do Estado, dá-se com a consolidação da ordenação através do decurso do tempo. Quando determinada ordenação consegue positividade, impondo-se ao respeito dos destinatários, e torna-se estável, adquirindo caráter permanente, aí então se pode dizer que existe poder soberano. DALLARI, Dalmo. Elementos de teoria geral do Estado. 2. ed. São Paulo: Saraiva, 1998. p. 33.
} 
Diante desse cenário, a concepção de que propriedade intelectual é sempre forma e de que é possível realizar uma análise unitária de seu conteúdo, desde a concepção até os seus efeitos, preservando-se os princípios ${ }^{26}$ que regem o sistema, pode resultar em método útil para a resolução do paradoxo referido acima, cuja incidência mostra-se cada vez mais frequente diante do fenômeno atual de expansão dos direitos conferidos pela propriedade intelectual. ${ }^{27}$

\footnotetext{
${ }^{26}$ Para Ricardo Lewandowski "Independentemente da preeminência que ostentam no âmbito do sistema ou da abrangência de seu impacto sobre a ordem legal, os princípios constitucionais, como se reconhece atualmente, são sempre dotados de eficácia, cuja materialização pode ser cobrada judicialmente se necessário. Sua eficácia, porém, varia segundo o grau de abstração ou generalidade que apresentam, podendo, conforme o caso, atribuir diretamente a alguém um direito subjetivo, estabelecer um padrão de interpretação a partir de uma hierarquia de valores, autorizar a invalidação de regras ou atos que lhes sejam contrários ou, ainda, impedir a revogação de normas que frustrem a materialização dos fins neles apontados". LEWANDOWSKI, Enrique Ricardo. Reflexões em torno do princípio republicano. Revista da Faculdade de Direito da Universidade de São Paulo, São Paulo, v. 100, p. 189-200, 2005. Disponível em: $<$ https://www.revistas.usp.br/rfdusp/article/view/67670/70278>.

${ }^{27}$ João Paulo Remédio Marques ressalta que: “Assiste-se, hoje, a uma expansão incomensurável não apenas do licere e do âmbito de protecção dos direitos de propriedade intelectual preexistentes, mas também a um aumento das espécies de direitos deste jaez, pois o legislador tem vindo a plasmar a tipificação e o correspondente regime jurídico de novéis direitos de propriedade intelectual. Os direitos de propriedade intelectual têm vindo, na verdade, a ser forçados a acomodar no seu seio criações e tecnologias jamais vistas como realidades protegidas." In: MARQUES, João Paulo Remédio. Propriedade intelectual e interesse público. Boletim da Faculdade de Direito de Coimbra - BFD, Coimbra, v. 79, p. 339, 2003. No mesmo sentido, Richard Posner ressalta que "The protection of intellectual property rights has expanded in recent decades. One reason is the dramatic fall in the quality-adjusted cost of (and delay in) copying, as a result of digitization; the best known example is computer file sharing of copyrighted music. The lower the cost of copying, the more difficult it is for the owner of the original work to recoup fixed costs in the price the owner charges for copies, unless the owner can prevent competitors from selling copies. Moreover, because of the expanding number and growing wealth of consumers worldwide and the fact that declining costs of disseminating intellectual property have brought more and more of the global market within the reach of producers of such property, the social value of a work that involves a heavy upfront investment, which is the defining characteristic of intellectual property, increases because the incremental cost of providing the work to additional customers is so slight. The social loss from undermining intellectual property rights is greater if, because of cheap copies and lack of intellectual property protection, the incentives to create such works, and hence the quality-adjusted number of such works, are diminished." in: POSNER, Richard. Intellectual property: the law and economics approach. Journal of Economic Perspective, v. 19, n. 2, p. 72, 2005. Tullio Ascarelli já havia previsto este fenômeno ao afirmar que "La importancia del interés público es especialmente la que explica por qué son tutelables tan sólo algunos tipos de creaciones intelectuales (aunque éstas puedan aumentar en número en futuras evoluciones legislativas), en contraste con la genérica apropiabilidad de todas las cosas materiales y energías que sean delimitables." ASCARELLI, Tullio. Teoria de la concurrencia y de los bienes inmateriales, cit., p. 278. Nesse sentido, Newton Silveira destaca que "A incerteza no enquadramento de tais tipos de obras [criações de forma e de função] pode levar o aplicador da lei a pecar por excesso, ampliando a proteção dessas obras mistas de modo a criar restrições ao avanço tecnológico, ou a pecar por escassez, negando ao autor o legítimo exercício de seus direitos de criação." SILVEIRA, Newton. Direito de autor no design, cit., p. 19. No mesmo sentido, Pedro Marcos Nunes Barbosa adverte que: "Dentro dessa concepção de que a adequada conservação de um sinalagma perante criador e criatura se mostra frágil perante direitos incidentes sobre bens imateriais, a tutela à propriedade intelectual é decorrente de séculos de avanços tecnológicos, científicos e artísticos. Dessarte saliente-se que a própria evolução tecnológica passou a demandar novas categorias jurídicas - ainda que dentro do mesmo gênero proprietário - para tutelar investimentos realizados em fisiologias evanescentes." BARBOSA, Pedro Marcos Nunes. Direito civil da propriedade intelectual, cit., p. 42.
} 


\section{CONCLUSÃO}

A afirmação de que propriedade intelectual é forma oferece uma nova perspectiva para se estudar o sistema de proteção ao esforço intelectual humano. Com efeito, a noção de que a forma é o veículo da emoção estética, fazendo eclodir o prazer intuitivo do homem, somado à percepção de que também é necessária para retirar da esfera pessoal do inventor e transmitir ao mundo exterior soluções puramente racionais, cujo escopo é o de resolver problemas inseridos na realidade objetiva, permite que o intérprete da lei tenha um guia para a solução do paradoxo da acumulação de diversas proteções sobre um único objeto (material ou imaterial), que pode se revelar ao mesmo tempo belo e útil.

A notícia histórica da formação do sistema da propriedade intelectual a partir da Revolução Industrial, que transformou profundamente a sociedade ao estabelecer novos meios de produção para substituir as corporações de ofício, e da Revolução Francesa, que ofereceu o arsenal jurídico necessário ao surgimento de uma nova estrutura social, ancorada na liberdade de trabalho e de comércio e, sobretudo, no direito de propriedade desligada da terra, também facilita a compreensão sobre a necessidade e a justificativa de se protegerem duas espécies de criadores: o autor no campo das artes e o inventor no campo da indústria.

Esse sistema tipicamente europeu espraiou-se para o mundo por meio de Tratados e Convenções Internacionais que uniformizaram o reconhecimento e a aplicação dos direitos da mente, inicialmente por uma espécie de federação de países formada pelas Convenções de Paris (propriedade industrial) e de Berna (direitos autorais), que disciplinaram regras a serem aplicadas entre particulares, e, posteriormente, por normas cogentes, com sanções inéditas no plano internacional, por meio das quais houve a fixação de padrões mínimos de proteção da propriedade intelectual impostos pelo TRIPS no ambiente do comércio multilateral.

Com o caminhar da história, significativos avanços se fizeram notar no tratamento da matéria da perspectiva constitucional e também do ponto de vista doutrinário, porquanto ficou devidamente assentada a asserção de que os direitos da propriedade intelectual, mais do que servirem a eventuais interesses egoísticos de seus titulares, são vetores do desenvolvimento cultural, tecnológico e econômico do País, tendo como pano de fundo o interesse social da nação. 
Nesse mesmo diapasão, também foi possível dar um novo significado aos institutos da propriedade intelectual a partir da compreensão de que não devem criar monopólios artificiais, abrindo clarões na concorrência, mas, sim, oferecer as condições necessárias para a inovação e a concorrência sadia de mercado, evitando o comportamento desleal e o aproveitamento parasitário do esforço e de investimentos alheios, seguindo-se, em síntese, o famoso preceito de Ulpiano: "viver honestamente, não lesar a outrem, dar a cada um o que é seu."

Note-se a propósito deste postulado que os direitos intelectuais têm a natureza jurídica de propriedade, uma vez que resultam do trabalho, fonte originária mais pura de aquisição de direitos, ainda mais se considerado o esforço daquele que traz ao mundo material algo que antes não existia ${ }^{439}$, seja com o propósito de alimentar a alma, seja para solucionar problemas técnicos oriundos da realidade objetiva. Com efeito, a Constituição Federal e as leis de regência da matéria vêm em abono a esta tese ao utilizarem a expressão "propriedade" para definir o vínculo jurídico que se estabelece entre o criador e a sua obra.

Ademais, ficou devidamente comprovado que o sistema da propriedade intelectual é composto por institutos cujas esferas de proteção não se interpenetram, cobrindo áreas estanques do engenho humano, cada qual com seus fundamentos e requisitos próprios, voltados para a consecução de uma determinada finalidade. A propriedade, por sua vez, também não é apenas um direito isolado, mas um verdadeiro feixe $\mathrm{e}^{440}$ de direitos ${ }^{441}$, dentre os quais se destaca a prerrogativa de afastar terceiros daquilo que pertence ao titular do domínio, concepção esta que, transposta para o sistema da propriedade intelectual, possibilita a compreensão de que o direito de propriedade inunda o sistema da propriedade intelectual como um todo, deixando nos seus compartimentos alguns fragmentos ${ }^{442}$.

\footnotetext{
${ }^{439}$ Vide, nesse sentido, interessante citação de Sain Exupery feita por Pedro Marcos Nunes Barbosa: "Bien sûr. Quand tu trouves um diamante n'est à personne, il est à toi. Quand tu troves une ilê qui nest à personne, ele est à toi. Quand tu as une idée le premier, tu la fais breveter: ele est à toi. Et moi je possêde les étoiles, puisque jamais personne avant moi n'a songé à les posseder”. SAIN - EXUPERY Apud BARBOSA, Pedro Marcos Nunes. Direito civil da propriedade intelectual, cit., p. 15.

${ }^{440}$ Para Silvio Venosa "Da propriedade decorrem todos os demais direitos reais. Ou, então em outras palavras, não existe direito real mais amplo do que a propriedade. Em última análise, a propriedade é o epicentro das relações obrigacionais, sucessórias e familiares”. VENOSA, Sílvio de Salvo. Direito civil: direitos reais, cit., v. 5, p. 39.

${ }^{441}$ Para Francisco Eduardo Loureiro: "É situação subjetiva complexa, feita de poderes, deveres, de obrigações e de limites. Nesse sentido, embora haja resistência, pode-se falar da propriedade com nitidez - usando como paradigma o pátrio poder -, o feixe de direitos e deveres que a integram". LOUREIRO, Francisco Eduardo. A propriedade como relação jurídica complexa, cit., p. 48.

${ }^{442}$ Eduardo Espínola ressalta que "Há uma pronunciada tendência atual para considerar a propriedade um direito natural, no sentido de ser inerente à natureza humana, indispensável à convivência social, reconhecida em todos os tempos, a despeito das diferenças formais" in ESPÍNOLA, Eduardo. Posse, propriedade, compropriedade ou condomínio, direitos autorais, cit., p. 152-153.
} 
Outro elemento chave para a harmonização do sistema é a fixação do critério de diferenciação entre aquilo que se insere no campo do belo (da estética) e o que pertence exclusivamente ao mundo da técnica, aquilo que é útil. Seguindo as pistas deixadas por Newton Silveira, pode-se concluir que a única maneira de se apropriar, com exclusividade, de conteúdo técnico é por meio da obtenção de uma patente, que protege soluções para problemas do nosso cotidiano, considerada a realidade objetiva, externa ao homem.

Por outro lado, como ensina Walter Moraes,

"[...] o belo é um conceito antes subjetivo que objetivo. Decorrente, embora, de
um móvel exterior, é no espírito que se consuma a manifestação do belo pelo
eclodir de uma emoção, de um prazer da percepção intuitiva, de admiração e
espanto de uma visão original de eternidade, de arrebatamento e saciedade, a
qual se denomina emoção estética (áisthesis = sensação e conhecimento). E o
estético se define pelo belo. A causa exterior que provoca semelhante comoção,
o belo objetivo, opera como tal porque incorpora ideias penetradas de intuição do
belo, revestindo-se de condições de totalidade proporcionais à predisposiçãa do
espírito para as emoções estéticas." ${ }^{443}$

Assim, no direito de autor, a forma é linguagem repleta de significado, como referido por Tullio Ascarelli, em contraposição a outras formas, cuja função técnica interdita qualquer possibilidade de significação, autorizando apenas um uso, porquanto desempenham tão somente uma função útil, como bem observa Guilherme Carboni.

Fixadas essas premissas, pode-se estabelecer uma relação de subsidiariedade entre a propriedade industrial e o direito de autor, uma vez que, embora os inventores possam também ser considerados autores no sentido amplo do termo (pais das invenções), não poderão retirar do direito autoral fundamento válido para proteger o conhecimento técnico.

Quanto ao confronto entre o direito de autor e os demais institutos da propriedade industrial, como, por exemplo, as marcas e os desenhos industriais, cumpre salientar que a definição das respectivas esferas de proteção também não autoriza que se conclua pela sobreposição de direitos, mas sim por uma harmonização de diferentes tutelas, mesmo porque a dupla ou a tripla proteção não teria nenhuma utilidade ou, na feliz expressão do Ministro Ricardo Lewandowski: "não é possível almoçar duas vezes no mesmo dia”.

Por todo o exposto e considerada a perspectiva proposta, percebe-se que há, em verdade, apenas um conflito aparente entre o direito de autor e a propriedade industrial, o que permite que convivam em harmonia, porquanto, além de uma saudável relação de complementariedade que se estabelece entre o belo e o útil, com vistas a coibir a

${ }^{443}$ MORAES, Walter. Arte, cit., v. 8, p. 142. 
concorrência desleal e o aproveitamento parasitário de esforços e investimentos alheios, aplica-se em casos fronteiriços o princípio da subsidiariedade, para que os direitos de propriedade intelectual sejam concedidos e exercidos para promover os ideais do legislador constitucional, impulsionando o País na direção do desenvolvimento econômico, tecnológico e cultural, considerado, em todos os casos, o interesse social. 


\section{REFERÊNCIAS}

ABREU, Jorge Manuel Coutinho de. Do abuso de direito. 1. ed. Porto: Almedina, 1999.

ALMEIDA, Marcus Elidius Michelli de. Abuso do direito e concorrência desleal. 1. ed. São Paulo: Quartier Latin, 2004.

ARNHEIM, Rudolf. Arte e percepção visual. São Paulo: Pioneira, 1997.

ARROW, Kenneth. Economic welfare and the allocation of resources for invention. In: THE RATE and direction of inventive activity: economic and social factors. New York: Arno Press, 1962. p. 609-625. Reimpressão, 1975. Disponível em: $<$ http://www.nber.org/chapters/c2144.pdf $>$.

ASCARELLI, Tullio. O desenvolvimento histórico do direito comercial e o significado da unificação do direito privado. Tradução de Fábio Konder Comparato. Revista de Direito Mercantil, Industrial, Econômico e Financeiro, São Paulo, v. 37, n. 114, abr./jun. 1999.

. Teoria de la concurrencia y de los bienes inmateriales. Trad. ao espanhol de E. Verdera; L. Suarez-Llanos. Barcelona: Bosch Casa Editorial, 1970.

ASCENSÃO, José de Oliveira. Direito autoral. Rio de Janeiro: Forense, 1980.

Direito autoral. 2. ed. Rio de Janeiro: Renovar, 1997.

O direito autoral numa perspectiva de reforma. In: WACHOWICZ, Marcos; SANTOS, Manuel Joaquim Pereira dos (Orgs.). Estudos de direito de autor: a revisão da Lei de Direitos Autorais. Anais do III Congresso de Direito de Autor e Interesse Público. [Recurso eletrônico]. Florianópolis: Fundação Boiteux, 2010. Disponível em: $<$ http://www.gedai.com.br/sites/default/files/publicacoes/livro_mw_estudodireitoautor.pdf $>$.

. O princípio da prestação: um novo fundamento para a concorrência desleal? In: CONCORRENCIA desleal - curso promovido pela Faculdade de Direito de Lisboa. Coimbra: Almedina, 1997.

ASSOCIAÇÃO BRASILEIRA DA PROPRIEDADE INDUSTRIAL. Resolução No 68 . Diretrizes para Exame de Contratos de Transferência de Tecnologia e Licenciamento de Direitos da Propriedade Intelectual sob uma Perspectiva do Direito Antitruste. Disponível em: $<$ http://www.abpi.org.br/biblioteca2a.asp?Ativo=True\&linguagem=Portugu $\%$ EAs\&secao=Bib lioteca\&subsecao $=$ Resolu\%E7\%F5es\%20da\%20ABPI\&id $=1>$. 
ATALIBA, Geraldo. Sistema constitucional tributário brasileiro. 1. ed. São Paulo: Revista dos Tribunais, 1968.

BANDEIRA, Manuel. Trem de Ferro. Disponível em: $<$ http://www.macvirtual.usp.br/mac/templates/projetos/jogo/tremdeferro.asp $>$.

BANDEIRA DE MELLO, Celso Antônio. Curso de direito administrativo. 16. ed. São Paulo: Malheiros Ed., 2003.

. Direito administrativo. São Paulo: Saraiva, 1975.

BANDEIRA DE MELLO, Oswaldo Aranha. Princípios gerais de direito administrativo. 3. ed. Rio de Janeiro: Forense, 2007. v. 1.

BAPTISTA, Pedro Martins. O abuso do direito e o ato ilícito. 3. ed. Rio de Janeiro: Forense, 2002.

BARBOSA, Cláudio Roberto. Propriedade intelectual enquanto informação. Uma perspectiva de "Law and Economics". California Digital Library. University of California, $2007 . \quad$ Disponível em: $<$ https://cloudfront.escholarship.org/dist/prd/content/qt9q80d5w8/qt9q80d5w8.pdf>.

. Propriedade intelectual: introdução à propriedade intelectual como informação. São Paulo: Campus Jurídico, 2008.

- A relação entre informação, propriedade intelectual, jurisdição e direito internacional. 2001. Dissertação (Mestrado) - Programa de Pós-Graduação em Direito, da Faculdade de Direito da Universidade de São Paulo, São Paulo, 2001.

BARBOSA, Denis Borges. Bases constitucionais da propriedade intelectual. Disponível em: <http://www.nbb.com.br/pub/propriedade13.pdf>. Acesso em: 13 nov. 2006.

. Como conciliar os ditames constitucionais da livre concorrência com o sistema de patentes? Disponível em: <www.nbb.com.br/ip/paten.html>. Acesso em: 13 nov. 2006.

. A criação de um ambiente competitivo no campo da propriedade intelectual: o caso Sul Americano. Disponível em: <http://denisbarbosa.addr.com/denis2.htm>. Acesso em: 10 out. 2017.

. Do requisito de originalidade nos desenhos industriais: a perspectiva brasileira.

Disponível em: $<$ http://www.denisbarbosa.addr.com/arquivos/novidades/do_requisito_originalidade.pdf $>$. . Tratado da propriedade intelectual. Rio de Janeiro: Lumen Juris, 2015. t. 4. 2003. . Uma introdução à propriedade intelectual. 2. ed. Rio de Janeiro: Lumen Juris, 
BARBOSA, Pedro Marcos Nunes. Direito civil da propriedade intelectual. 3. ed. Rio de Janeiro: Lumem Juris, 2016.

BARCELLOS, Milton Lucídio Leão. Propriedade industrial \& constitucional: as teorias preponderantes e sua interpretação na realidade brasileira. Porto Alegre: Livr. do Advogado, 2007.

BARRETO FILHO, Oscar. Teoria do estabelecimento comercial: fundo do comércio ou fazenda mercantil. 2. ed. São Paulo: Saraiva, 1988.

BASSO, Maristela. O direito internacional da propriedade intelectual. Porto Alegre: Livr. do Advogado, 2000.

. O direito de propriedade intelectual das empresas montadoras de autopeças, a proteção do consumidor e o direito antitruste. Revista Brasileira da Advocacia, São Paulo, ano 2, v. 4, 2017.

Os fundamentos atuais do direito internacional da propriedade intelectual. Conferência proferida no "Seminário sobre Direito Autoral", realizado pelo Centro de Estudos Judiciários, nos dias 17 e 18 de março de 2003, no Centro Cultural Justiça Federal, Rio de Janeiro - RJ. Revista CEJ, Brasília, v. 7 n. 21, p. 16, abr./jun. 2003. Disponível em: $<$ http://www.cjf.jus.br/ojs2/index.php/revcej/article/view/541/721>.

BAUMAN, Zygmunt. Modernidade líquida. Traduzido por: Plínio Dentzien. Rio de Janeiro: Zahar, 2001.

BENUTTI, Benassi. Tutela della forma nel diritto industriale: forme distintive e modelli industriali. Milano: Giuffrè, 1963.

BERTONE, Luis Eduardo; CABANELLAS DE LAS CUEVAS, Guillermo. Derecho de marcas: marcas, designaciones y nombres comerciales. 1. ed. Buenos Aires: Heliasta, 1989. t. 1.

BESSONE, Darcy. Direitos reais. São Paulo: Saraiva, 1988.

BILAC, Olavo. Profissão de Fé. Disponível em: $<$ http://www.biblio.com.br/defaultz.asp?link=http://www.biblio.com.br/conteudo/OlavoBil ac/profissaodefe.htm>.

BITTAR, Carlos Alberto. Autonomia científica do direito de autor. Revista da Faculdade de Direito da Universidade de São Paulo, São Paulo, v. 89, p. 87-98, jan./dez. 1994. Disponível em: <http://www.revistas.usp.br/rfdusp/article/view/67238/69848>.

A concorrência desleal e a confusão entre produtos. Revista dos Tribunais, São Paulo, v. 550, ago. 1981.

. Direito de autor. Rio de Janeiro: Forense, 1992. 
BOBBIO, Norberto. Direito e ciências sociais. In: BOBBIO, Norberto. Da estruturação à função: novos estudos de teoria do direito. Barueri, SP: Manole, 2010.

BURKE, Edmund. Investigação filosófica sobre a origem das nossas ideias do sublime e da beleza. 1. ed. São Paulo: Edipro, 2016.

BURST, Jean-Jacques. Concurrence déloyale et parasitisme. Paris: Dalloz, 1993.

CÂMARA DOS DEPUTADOS. Centro de Estudos de Debates Estratégicos. A revisão da lei de patentes: inovação em prol da competitividade nacional. Brasília: Biblioteca Digital da Câmara dos Deputados, 2013. Disponível em: <http://www2.camara.leg.br/acamara/altosestudos/seminarios/lancamento-patentes-9-10-13/a-revisao-da-lei-depatentes>.

A revisão da lei de patentes: inovação em prol da competitividade nacional. Brasília: Centro de Estudos e Debates Estratégicos, 2013. Disponível em: $<$ http://www2.camara.leg.br/a-camara/estruturaadm/altosestudos/seminarios/lancamentopatentes-9-10-13/a-revisao-da-lei-de-patentes $>$.

CAMBRIDGE Learner's dictionary. New York: Cambrige University Press, 2001.

CARBONI, Guilherme. O direito de autor na multimídia. São Paulo: Quartier Latin, 2003. . Função social do direito de autor. Curitiba: Juruá, 2008.

CARNEIRO, Renata Pozzato. A função social da propriedade na Constituição da República de 1988 e a propriedade industrial. Revista da ABPI, Rio de Janeiro, n. 69, p. 23-30, mar./abr. 2004.

CARRIÓ, Genaro R. Notas sobre derecho y lenguaje. Buenos Aires: Abeledo-Perrot, 1990.

CARVAlHO, Américo da Silva. Concorrência desleal (princípios fundamentais). Coimbra: Coimbra Ed., 1984.

CARVALHO, Nuno Pires de. A propriedade intelectual como fator de diferenciação e o papel fundamental que desempenha para assegurar a livre-concorrência. Revista dos Tribunais, São Paulo, v. 105, n. 968, p. 262-263, jun. 2016.

CASSIRER, Ernest. Ensaio sobre o homem. São Paulo: Martins Fontes, 2005.

. The philosophy of symbolic forms. Trad. Ralph Manheim. New Haven: Yale University Press, 1957. v. 3. 
CERQUEIRA, João da Gama. O direito de autor como direito de propriedade. Revista dos Tribunais, São Paulo, ano 47, v. 270, abr. 1958. v. 1, t. 1 .

. Tratado da propriedade industrial. 1. ed. Rio de Janeiro: Revista Forense, 1956.

. Tratado da propriedade industrial. Atualizada por Luiz Gonzaga do Rio Verde e João Casimiro Costa Neto. 2. ed. rev. e atual. São Paulo: Revista dos Tribunais, 1982. v. 2.

CHAVES, Antonio. Direitos autorais. Curitiba: Juruá, 1985.

CLARET, Jacques. A idéia e a forma: problemática e dinâmica da linguagem. Rio de Janeiro: Zahar, 1980.

COMPARATO, Fábio Konder. Aspectos jurídicos da macroempresa. 1. ed. São Paulo: Revista dos Tribunais, 1970.

Função social da propriedade dos bens de produção. Revista de Direito Mercantil, Industrial, Econômico e Financeiro, São Paulo, v. 25, n. 63, p. 71 e ss., jul./set. 1986.

1965.

. O indispensável direito econômico. Revista dos Tribunais, São Paulo, v. 353, mar. 1976.

O poder de controle na sociedade anônima. São Paulo: Revista dos Tribunais, . O poder de controle nas S/A. 3. ed. São Paulo: Saraiva, 1996.

CONSELHO ADMINISTRATIVO DE DEFESA ECONÔMICA - CADE. Ato de Concentração N $\mathrm{N}^{\circ}$ 27/95. Requerentes: K \& S Aquisições Ltda. e Kolynos Do Brasil S/A. Revista do IBRAC, (Caderno de jurisp.), São Paulo, v. 3, n. 10, out. 1996. Disponível em: $<$ http://www.ibrac.org.br/UPLOADS/PDF/RevistadoIBRAC/Revista $\% 203 \% 20 \mathrm{n} \% \mathrm{C} 2 \% \mathrm{BA} \%$ 2010.pdf $>$.

Averiguação Preliminar 080012.002673/2007-51. Relator: Conselheiro Carlos Emmanuel Joppert Ragazzo. Disponível em: <http://www.anfape.org.br/imagens/VotoConselheiro-Carlos-E-J-Ragazzo15-12-10.pdf>.

CORREA, José Antonio L. B. O Projeto de Lei da Propriedade Industrial e o TRIPS - a fraude na apropriação de marcas não pré-registradas. Revista da ABPI, Rio de Janeiro, n. 17, p. 35-37, jul./ago. 1995.

CORTIANO JR., Eroulths. O discurso jurídico da propriedade e suas rupturas: uma análise do ensino do direito de propriedade. Rio de Janeiro: Renovar, 2002. p. 60.

COSTA NETO, José Carlos. Direito autoral no Brasil. São Paulo: FTD, 2008. 
DALLARI, Dalmo. Elementos de teoria geral do Estado. 2. ed. São Paulo: Saraiva, 1998.

DASGUPTA, Partha; STIGLITZ, Joseph. Uncertainty, industrial structure and the speed of R\&D. The Bell Journal of Economics and Management Science, Santa Monica-CA, v. 11, n. 1, p. 1-28, 1980.

DELMANTO, Celso. Crimes de concorrência desleal. São Paulo: Bushatsky; EDUSP, 1975.

DEMSETZ, Harold. Information and efficiency: another viewpoint. The Journal of Law and Economics, Chicago, v. 12, n. 1, p. 1-22, 1969.

DIAS, José Carlos Vaz e. Licença compulsória de patentes e o direito antitruste. Revista da ABPI, Rio de Janeiro, n. 54, p. 3-8, set./out. 2001.

DI BLASI, Gabriel. Questões atuais na proteção de desenhos industriais. Revista da ABPI, Rio de Janeiro, n. 93, p. 3-10, mar./abr. 2008.

DIDEROT, D. Ensaio sobre a pintura. Introd. e notas de Enid Abreu Dobransky. Campinas: Papirus, 1993.

DINIZ, Maria Helena. Dicionário jurídico. São Paulo: Saraiva, 1998.

DI PIETRO, Maria Sylvia Zanella. Curso de direito administrativo. 25. ed. São Paulo: Atlas, 2012.

DURVAL, Hermano. Concorrência desleal. São Paulo: Saraiva, 1976.

ECO, Umberto. A definição de arte. Trad. Eliana Aguiar. 1. ed. Rio de Janeiro: Record, 2016.

ESPÍNOLA, Eduardo. Posse, propriedade, compropriedade ou condomínio, direitos autorais. Atual. por: Ricardo Rodrigues Gama. 1. ed. Campinas: Bookseller, 2002.

FEKETE, Elisabeth G. Kasznar. O regime jurídico do segredo de comércio no direito brasileiro. 1. ed. Rio de Janeiro: Forense, 2003.

FERRAZ JR. Tércio Sampaio. Propriedade industrial e defesa da concorrência. Revista da ABPI, v. 2, n. 8, p. 10-12, maio/jun. 1993.

FERREIRA, Waldemar. Tratado de direito comercial. São Paulo: Saraiva, 1962. v. 6.

FERREIRA FILHO, Manoel Gonçalves. Comentários à Constituição brasileira de 1988. São Paulo: Saraiva, 1975. v. 3. 
FONSECA FILHO, Antônio. Concorrência e propriedade intelectual. Revista da ABPI, n. 36, p. 3-24, set./out. 1998.

FORGIONI, Paula A. Direito concorrencial e restrições verticais. São Paulo: Revista dos Tribunais, 2007.

. Princípios constitucionais econômicos e princípios constitucionais sociais. In: ANDRADE, José Maria Arruda de; COSTA, José Augusto Fontoura; MATSUO, Alexandra Mery Hansen (Coords.). Direito: teoria e experiência: estudos em homenagem a Eros Roberto Grau. São Paulo: Malheiros Ed., 2013. v. 1.

Princípios constitucionais econômicos e princípios constitucionais sociais: a formatação jurídica do mercado brasileiro. Revista do Advogado, São Paulo, v. 32, n. 117, p. 167-168, out. 2012.

. O que esperar do antitruste brasileiro no século XXI? RJLB, ano 1, n. 1, p. 1729, $2015 . \quad$ Disponível em: $<$ http://www.cidp.pt/publicacoes/revistas/rjlb/2015/1/2015_01_1713_1742.pdf $>$. Acesso em: 16 abr. 2017.

FRANÇA, Rubens Limongi (Org.). Enciclopédia Saraiva do Direito. 1. ed. São Paulo: Saraiva, 1977. v. 2.

FROÉS, Carlos Henrique de Carvalho. Anais do XVIII Seminário Nacional da Propriedade Intelectual. Revista da ABPI, Rio de Janeiro, 1998.

FURTADO, Lucas Rocha. Sistema de propriedade industrial no direito brasileiro: comentários à nova legislação sobre marcas e patentes, Lei n. 9.279, de 14 de maio de 1996 1. ed. Brasília: Brasília Jurídica, 1996.

GIACCHETTA, André Zonaro. A evolução do direito industrial e a sua relação com o direito da concorrência. Trabalho apresentado no Curso de Pós-Graduação, da Faculdade de Direito da Universidade de São Paulo, São Paulo, 2004. Cópia cedida pelo autor.

GOMPERTZ, Will. Isso é arte? 150 anos de arte moderna do impressionismo até hoje. Trad. Maria Luiza X. de A. Borges. 1. ed. Rio de Janeiro: Zahar, 2013.

GRAU, Eros Roberto. O direito posto e o direito pressuposto. 9. ed. São Paulo: Malheiros Ed., 2014.

. A Ordem Econômica na Constituição de 1988: interpretação e crítica. 11. ed. rev. e atual. São Paulo: Malheiros Ed., 2006.

. A Ordem Econômica na Constituição de 1988: interpretação e crítica. 14. ed. rev. e atual. São Paulo: Malheiros Ed., 2010. 
GRAU, Eros Roberto. A Ordem Econômica na Constituição de 1988: interpretação e crítica. 17. ed. atual. São Paulo: Malheiros Ed., 2015.

; FORGIONI, Paula Andréa. CADE vs. BACEN: conflitos de competência entre autarquias e a função da advocacia-geral da União. Revista de Direito Mercantil, Industrial, Econômico e Financeiro, São Paulo, v. 53, n. 135, p. 7-25, jul./set. 2004.

GRAU-KUNTZ, Karin. Direito de patentes - sobre a interpretação do artigo $5^{\circ}$, XXIX da Constituição brasileira. Cruzeiro/Newmarc Propriedade Intelectual. Disponível em: $<$ http://www.newmarc.com.br/ibpi/d_pat.html $>$.

. Do nome das pessoas jurídicas. São Paulo: Malheiros Ed., 1998.

GREFFE, Pierre; GREFFE, Francois. Trailé der dessins et des modêles: France Union européenne - Suisse. 6. ed. Paris: LITEC. 2000.

HOBSBAWM, E. J. A era das revoluções. 9. ed. São Paulo: Paz e Terra, 1996.

HOBSON, John A. A evolução do capitalismo moderno: um estudo da produção mecanizada. São Paulo: Nova Cultural, 1985.

HOUAISS, Antônio. Dicionário Houaiss da língua portuguesa. 2. ed. Rio de Janeiro: Nova Fronteira, 1982.

. Dicionário Houaiss da língua portuguesa. Rio de Janeiro: Objetiva, 2009.

I WAS Diagnosed with schizophrenia at the age of 17, So I Started Drawing My Hallucinations To Cope With It. Boredpanda. Disponível em: $<$ https://www.boredpanda.com/18-year-old-schizophrenic-artist-drawing-hallucinations/>.

INWOOD, Michael. Dicionário Hegel. Tradução Álvaro Cabral. Rio de Janeiro: Jorge Zahar, 1993. (Dicionários de Filósofos).

JABUR, Wilson Pinheiro. Interface entre propriedade industrial e direito do autor. In: SANTOS, Manoel Joaquim Pereira dos; JABUR, Wilson Pinheiro (Orgs.). Propriedade intelectual: direito autoral. São Paulo: Saraiva, 2014.

KANITZ, Stephen. O administrador como político. Veja, São Paulo, ed. 1963, 05 jul. 2006. Disponível em: <http://origin.veja.abril.com.br/050706/ponto_de_vista.html>.

KELSEN, Hans. Teoria pura do direito. Trad. João Batista Machado. 6. ed. São Paulo: Martins Fontes, 1998.

KUYKENDALL, Lara. Duchamp, The Bride Stripped Bare by Her Bachelors, Even (The Large Glass). Disponível em: < https://www.khanacademy.org/humanities/art-1010/wwidada/dada1/a/duchamp-the-bride-stripped-bare-by-her-bachelors-even>. 
LACOSTE, Jean. A filosofia da arte. Rio de Janeiro: Zahar, 2011.

LANDES, William M.; POSNER, Richard A. The economic structure of intellectual property law. Cambridge: The Beknap Press of Harvard University, 2003.

LE MOAL, Roger. Droit de concurrence. $1^{\text {ére }}$ ed. Paris: Economica, 1979.

LEONARDOS, Gabriel F. A relação entre o direito antitruste e o direito da propriedade industrial. Revista da ABPI, Rio de Janeiro, n. esp. p. 119-124, 1996.

LEONARDOS, Luiz; KUNISAWA, Viviane Yumy. O sistema de propriedade intelectual como fomentador da inovação tecnológica. Revista da ABPI, Rio de Janeiro, n. 76, p. 1621, maio/jun. 2005. SOLOW, Robert. Technical change and the aggregate production function. The Review of Economics and Statistics, v. 39, n. 3, p. 312-320, Aug. 1957.

LEWANDOWSKI, Enrique Ricardo. A formação da doutrina dos direitos fundamentais. In: SILVA, Marco Antonio Marques da (Coord.). Tratado Luso-brasileiro da dignidade humana. 2. ed. São Paulo: Quartier Latin, 2009.

. Reflexões em torno do princípio republicano. Revista da Faculdade de Direito da Universidade de São Paulo, São Paulo, v. 100, p. 189-200, 2005. Disponível em: $<$ https://www.revistas.usp.br/rfdusp/article/view/67670/70278>.

A reforma do judiciário e o federalismo brasileiro. Revista do Advogado, São Paulo, n. 56, p. 41-42, set. 1999.

LICKS, Otto. Inter-relação entre desenhos industriais, marcas figurativas e tridimensionais e direitos autorais. In: SEMINÁRIO NACIONAL DA PROPRIEDADE INTELECTUAL, 18., 1998, São Paulo. Rio de Janeiro: ABPI, 1998.

LIMA, João Alberto de Oliveira; PASSOS, Edilene; NICOLA, João Rafael. A gênese do texto da Constituição de 1988. Brasília-DF: Gráfica do Senado Federal, 2013.

LOUREIRO, Francisco Eduardo. A propriedade como relação jurídica complexa. São Paulo: Renovar, 2003.

MARQUES, João Paulo Remédio. Propriedade intelectual e interesse público. Boletim da Faculdade de Direito de Coimbra - BFD, Coimbra, v. 79, p. 293-354, 2003.

MEIRELLES, Hely Lopes. Direito administrativo brasileiro. 25. ed. São Paulo: Malheiros Ed., 2000.

MENDES, Gilmar Ferreira. Curso de direito constitucional. 7. ed. São Paulo: Saraiva, 2012 .

MENDONÇA, J. X. Carvalho de. Tratado de direito comercial. São Paulo: Freitas Bastos, 1963. v. 5. 
MILLER, Arthur; DAVIS, Michael. One court has articulated the test as being whether the device is "primarily utilitarian". Rolls-Royce Motors Ldt. V. A \& A Fiberglass, 1977.

MIRANDA, Francisco Cavalcanti Pontes de. Comentários ao Código de Processo Civil. 5. ed. Rio de Janeiro: Forense, 1995.

. Tratado de direito privado: parte especial. 3. ed. Rio de Janeiro: Borsoi, 1972. t.

17.

MOLINER, María. Diccionario de uso del español. Madrid: Gredos, 1997.

MONTEIRO, Washington de Barros. Curso de direito civil. 38. ed. São Paulo: Saraiva, 2001.

MONTORO, André Franco. Introdução à ciência do direito. 31. ed. São Paulo: Revista dos Tribunais, 2014.

MONTORO FILHO, André Franco. Convite ao diálogo. In: DIREITO e economia. São Paulo: Saraiva, 2008.

MORAES, Alexandre de. Direito constitucional. 19. ed. São Paulo: Atlas, 2009.

MORAES, Walter. Arte. In: FRANÇA, Rubens Limongi (Org.). Enciclopédia Saraiva do Direito. São Paulo: Saraiva, 1977. v. 8.

NOËL, Émile (Org.). As ciências da forma hoje. Tradução de Cid Knipel Moreira. Campinas: Papirus, 1986.

NORONHA, E. Magalhães. Direito penal. São Paulo: Saraiva, 1983. v. 3.

OKEDIJI, Ruth L. The international relations of intellectual property: narratives of developing country participation in the global intellectual property system. Singapore Journal of International \& Comparative Law, n. 7, p. 315-385, 2003.

OLAVO, Carlos. Propriedade industrial: sinais distintivos do comércio, concorrência desleal. 2. ed. Coimbra: Almedina, 2005.

OLIVEIRA, Régis Fernandes. Direito e arte. São Paulo: Malheiros Ed., 2017.

OLIVEIRA, Maurício Lopes de. Obras de domínio público e seu registro como marca. Revista da Associação Brasileira de Propriedade Intelectual - RABPI, São Paulo, n. 25, p. 50-55, nov./dez 1996,

ORGANIZATION FOR ECONOMIC COOPERATION AND DEVELOPMENT (OECD). Competition Committee. Competition, Patents and Innovation II. Policy Roundtables, Paris, Jun. 2009. 
PAREYSON, Luigi; GARCEZ, Maria Helena Nery. Os problemas da estética. 3. ed. São Paulo: Martins Fontes, 1997.

PEREIRA, Alexandre. Propriedade intelectual, concorrência desleal e sua tutela (penal) em Portugal. Revista da ABPI, Rio de Janeiro, n. 56, p. 15-34, jan./fev. 2002.

PEREIRA, Caio Mário da Silva. Instituições de direito civil. 18. ed. Rio de Janeiro: Forense, 1995. v. 1.

PERLINGIERI, Pietro. Perfis do direito civil: introdução ao direito civil constitucional. 3. ed. Rio de Janeiro: Renovar, 2007.

POSNER, Richard. Intellectual property: the law and economics approach. Journal of Economic Perspective, v. 19, n. 2, 2005.

RAMOS, André Luiz Santa Cruz. Direito empresarial esquematizado. 4. ed. Rio de Janeiro: Método, 2012.

REALE, Miguel. Lições preliminares do direito. 24. ed. São Paulo: Saraiva, 1998.

REQUIÃO, Rubens. Abuso de direito e fraude através da personalidade jurídica. Revista dos Tribunais, São Paulo, ano 58, v. 410, p. 12-24, dez. 1969.

RIPERT, Georges. Aspectos jurídicos do capitalismo moderno. Trad. de Gilda G. de Azevedo. Rio de Janeiro: Freitas Bastos, 1947.

RODRIGUES, Clovis Costa. Concorrência desleal. Rio de Janeiro: Editorial Peixoto, 1945.

RODRIGUES, Silvio. Direito civil: parte geral. 24. ed. São Paulo: Saraiva, 1994. v. 1.

. Direito civil: parte geral. 34. ed. São Paulo: Saraiva, 2003. v. 1.

ROSENBERG, Bárbara. Patentes de medicamentos e comércio internacional: os parâmetros do TRIPS e do direito concorrencial para a outorga de licenças compulsórias. 2004. Tese (Doutorado) - Programa de Pós-Graduação em Direito, da Faculdade de Direito da Universidade de São Paulo, São Paulo, 2004.

ROSS, Alf. Direito e justiça. Tradução e notas de Edson Bini. 1. ed. Bauru-SP: Edipro, 2000 . 2003.

. Direito e justiça. Tradução e notas de Edson Bini. 1. reimpr. Bauru-SP: Edipro,

SABNANI, Sanjay. Why are the Andy Warhol soup can paintings considered great art? Quora, Aug. 17 2013. Disponível em: <https://www.quora.com/Why-are-the-AndyWarhol-soup-can-paintings-considered-great-art>. 
SALOMÃO FILHO, Calixto. Direito concorrencial: as condutas. 1. ed. São Paulo: Malheiros Ed., 2003.

- Direito industrial, direito concorrencial e interesse público. Revista de Direito Público da Economia, ano 2, n. 7, p. 29-44, 2004. Disponível em: $<$ http://aplicaext.cjf.jus.br/phpdoc/pages/sen/portaldaeducacao/textos_fotos/inpi/di.pdf>.

SANTIAGO FILHO, Willis. O princípio da proporcionalidade em direito constitucional e em direito privado no Brasil. Mundo Jurídico, 10 maio 2003 Disponível em: $<$ http://www.mundojuridico.adv.br/sis_artigos/artigos.asp?codigo=701>.

SANTOS, Manoel Joaquim Pereira dos. Principais tópicos para uma revisão da lei de direitos autorais brasileira. In: WACHOWICZ, Marcos; SANTOS, Manoel Joaquim Pereira dos (Orgs.). Estudos de direito do autor e a revisão da lei dos direitos autorais. Florianópolis: Fundação Boiteux, 2010.

; JABUR, Wilson Pinheiro (Orgs.). Propriedade intelectual: direito autoral. São Paulo: Saraiva, 2014.

SANTOS JR., Walter Godoy dos. Contribuição para o estudo da marca tridimensional. 2007. Dissertação (Mestrado) - Programa de Pós-Graduação em Direito, da Faculdade de Direito da Universidade de São Paulo, São Paulo, 2007.

SARMENTO, Daniel. Direitos fundamentais e relações privadas. 2. ed. Rio de Janeiro: Lumem Juris, 2010.

SAVIGNY, Friedrich Karl von. Metodologia jurídica. 1. ed. Campinas: Edicamp, 2004.

SICHEL, Ricardo. A patente e a concorrência. In: SICHEL, Ricardo. O direito europeu de patentes e outros estudos de propriedade industrial. Rio de Janeiro: Lumen Júris, 2004. p. 109-110. (Coleção Propriedade Intelectual Denis Borges Barbosa).

SILVA, José Afonso da. Curso de direito constitucional positivo. 18. ed. São Paulo: Malheiros Ed., 2000.

. Curso de direito constitucional positivo. 19. ed. São Paulo: Malheiros Ed., 2001.

. Curso de direito constitucional positivo. 25. ed. São Paulo: Malheiros Ed., 2005.

SILVA, Luís Virgílio Afonso da. O proporcional e o razoável. Revista dos Tribunais, São Paulo, v. 91, n. 798, p. 23-50, abr. 2002. Disponível em: $<$ http://www.revistas.unifacs.br/index.php/redu/article/viewFile/1495/1179>.

SILVEIRA, Newton. Abuso de patentes. Disponível em: <http://www.lexnet.com/new/wp-content/uploads/2014/10/50-Abuso-de-patentes.pdf $>$. 
SILVEIRA, Newton. Anotações acerca do desenho industrial comunitário europeu. Cruzeiro/Newmarc Propriedade Intelectual. Disponível em: $<$ http://www.newmarc.com.br/novo-antigo/index.asp?p=artigos.asp\&m=000143>. Acesso em: 13 nov. 2006.

. Direito de autor no design. 2. ed. São Paulo: Saraiva, 2012.

. O direito autoral no projeto de arquitetura perante a doutrina e a jurisprudência. Revista de Direito Empresarial: ReDE, v. 2, n. 2, p. 247-254, mar./abr. 2014.

. Estudos e pareceres de propriedade intelectual. Organização e Seleção de Wilson Silveira. Rio de Janeiro: Lumen Juris, 2008. Disponível em: $<$ https://ibpieuropa.org/book/silveira-newton-estudos-e-pareceres $>$.

- Garantias constitucionais aos bens imateriais. Revista de Direito Mercantil, Industrial, Econômico e Financeiro, São Paulo, v. 24, n. 60, p. 18-23, out./dez. 1985.

Problemas da propriedade intelectual. Disponível em: $<$ www.silveiraadvogados.com.br/port/artigo-completo.asp?id=23>.

. Propriedade imaterial e concorrência. Revista dos Tribunais, São Paulo, ano 75, n. 604, p. 264-271, fev. 1986.

. Propriedade intelectual. 5. ed. São Paulo: Manole, 2014.

. A propriedade intelectual no novo Código Civil brasileiro. Disponível em: $<$ http://www.silveiraadvogados.com.br/port/artigo-completo.asp?id=19>. Acesso em: 13 nov. 2003.

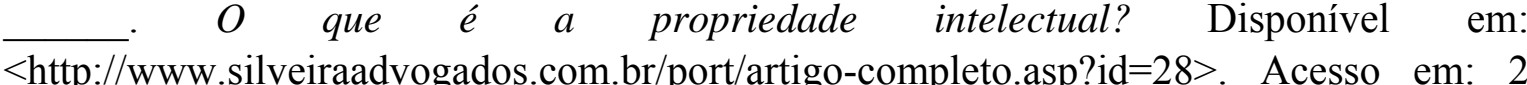
fev. 2017.

. O que uma norma técnica não é. 1. ed. São Paulo: Target, 2014.

SOBOUL, Albert. A Revolução Francesa. 9. ed. Tradução de Rolando Roque da Silva. Rio de Janeiro: DIFEL, 2007. p. 10.

STAMMLER, Rudolf. La génesis del derecho. Granada: Comares, 2006. p. 20.

STIGLITZ, Joseph. É hora de questionar as patentes. Tradução: Cristiana Martin. 17/07/2013. Disponível em: <http://outraspalavras.net/posts/stiglitz-e-hora-de-questionaras-patentes/>.

STRENGER, Irineu. Reparação de dano em direito internacional privado. 1. ed. São Paulo: Revista dos Tribunais 1973. 
TELLES JR., Goffredo. O direito quântico: ensaio sobre o fundamento da ordem jurídica. 8. ed. São Paulo: Juarez de Oliveira, 2006.

THORÉ, Théophile. Le salon de 1847; précédé d'une Lettre à Firmin Barrion. Paris: Alliance des Arts, 1847.

U.S. DEPARTMENT OF JUSTICE (DOJ); FEDERAL TRADE COMMISSION (FTC). Antitrust Guidelines for the Licensing of Intellectual Property. Apr. 1995.

VAZ, Isabel. Direito econômico da concorrência. 1. ed. Rio de Janeiro: Forense, 1993.

VENOSA, Sílvio de Salvo. Direito civil: direitos reais. 3. ed. São Paulo: Atlas, 1999. v. 5.

WEBER, Max. A ética protestante e o espírito do capitalismo. São Paulo: Pioneira, 1976. p. 25.

WHITTELL, Scarlett. Academic and Creative Classes for Kids. July 3, 2017. Disponível em: $<$ http://hk.localiiz.com/after-school-classes-kids-roundup-academic-creative/>.

WISH, Richard. Competition law. $4^{\text {th }}$ ed. Bath, UK: Butterworths, 2001. 
ANEXOS 


\section{DECRETO Nº 75.699, DE 6 DE MAIO DE 1975}

Promulga a Convenção de Berna para a Proteção das Obras Literárias e Artísticas, de 9 de setembro de 1886, revista em Paris, a 24 de julho de 1971.

O PRESIDENTE DA REPÚBLICA, havendo o Congresso Nacional aprovado, pelo Decreto Legislativo n ${ }^{\circ}$ 94, de 4 de dezembro de 1974, a Convenção de Berna para a Proteção das Obras Literárias e Artísticas, concluída a 9 de setembro de 1886 e revista em Paris, a 24 de julho de 1971; E havendo a referida Convenção entrado em vigor, para o Brasil, em 20 de abril de 1975; DECRETA:

que a Convenção, apensa por cópia ao presente Decreto, seja executada e cumprida tão inteiramente como nela se contém.

Brasília, 6 de maio de 1975; $154^{\circ}$ da Independência e 87º da República.

ERNESTO GEISEL

Antônio Francisco Azeredo da Silveira

CONVENÇÃO DE BERNA PARA A PROTEÇÃO DAS OBRAS LITERÁRIAS E ARTÍSTICAS, DE 9 DE SETEMBRO DE 1886, COMPLETADA EM PARIS A 4 DE MAIO DE 1896, REVISTA EM BERLIM A 13 DE NOVEMBRO DE 1908, COMPLETADA EM BERNA A 20 DE MARÇO DE 1914, REVISTA EM ROMA A 2 DE JUNHO DE 1928, EM BRUXELAS A 26 DE JUNHO DE 1948, EM ESTOCOLMO A 14 DE JULHO DE 1967 E EM PARIS A 24 DE JULHO DE 1971.

Os Países da União, igualmente animados do propósito de proteger de maneira tanto quanto possível eficaz e uniforme os direitos dos autores sobre as respectivas obras literárias e artísticas,

Reconhecendo a importância dos trabalhos da Conferência de revisão, realizada em Estocolmo em 1967,

Resolveram rever o Ato adotado pela Conferência de Estocolmo, deixando entretanto sem modificações os artigos de 1 a 20 e de 22 a 26 do referido Ato.

Em consequência, os Plenipotenciários abaixo assinados, depois de apresentar seus plenos poderes, reconhecidos em boa e devida forma, acordaram no seguinte:

\section{ARTIGO 1}

Os países a que se aplica a presente Convenção constituem-se em União para a proteção dos direitos dos autores sobre as suas obras literárias e artísticas.

\section{ARTIGO 2}

1) Os temas "obras literárias e artísticas", abrangem todas as produções do domínio literário, cientifico e artístico, qualquer que seja o modo ou a forma de expressão, tais como os livros, brochuras e outros escritos; as conferências, alocuções, sermões e outras obras da mesma natureza; as obras dramáticas ou dramático-musicais; as obras coreográficas e as pantominas; as composições musicais, com ou sem palavras; as obras cinematográficas e as expressas por processo análogo ao da cinematografia; as obras de desenho, de pintura, de arquitetura, de escultura, de gravura e de litografia; as obras fotográficas e as expressas por processo análogo ao da fotografia; 
as obras de arte aplicada; as ilustrações e os mapas geográficos; os projetos, esboços e obras plásticas relativos à geografia, à topografia, á arquitetura ou às ciências.

2) Os Países da União reservam-se, entretanto, a faculdade de determinar, nas suas legislações respectivas, que as obras literárias e artísticas, ou ainda uma ou várias categorias delas, não são protegidos enquanto não tiverem sido fixadas num suporte material.

3) são protegidas como obras originais, sem prejuízo dos direitos do autor da obra original, as traduções, adaptações, arranjos musicais e outras transformações de uma obra literária ou artística.

4) Os Países da União reservam-se a faculdade de determinar, nas legislações nacionais, a proteção a conceder aos textos oficiais de caráter legislativo, administrativo ou judiciário, assim como as traduções oficiais desses textos.

5) As complicações de obras literárias ou artísticas, tais como enciclopédias e antologias, que, pela escolha ou disposição das matérias, constituem criações intelectuais, são como tais protegidas, sem prejuízo dos direitos dos autores sobre cada uma das obras que fazem parte dessas compilações.

6) As obras acima designadas gozam de proteção em todos os países unionistas. A proteção exerce-se em beneficio dos autores e de seus legítimos representantes.

7) Os países da União, reservam-se a faculdade de determinar, nas legislações nacionais, o âmbito de aplicação das leis referentes às obras de arte aplicada e aos desenhos e modelos industriais, assim como as condições de proteção de tais obras, desenhos e modelos, levando em conta as disposições do artigo 7.4) da presente Convenção. Para as obras protegidas exclusivamente como desenhos e modelos no país de origem não pode ser reclamada, nos outros países unionistas, senão a proteção especial concedida aos desenhos e modelos nesses países; entretanto, se tal proteção especial não é concedida nesse país, estas obras serão protegidas como obras artísticas.

8) A proteção da presente Convenção não se aplica às notícias do dia ou à ocorrências diversas que têm o caráter de simples informações de imprensa.

\section{ARTIGO 2 bis}

1) Os países da União reservam-se a faculdade de excluir, nas legislações nacionais, parcial ou totalmente, da proteção prevista no artigo anterior os discursos políticos e os discursos pronunciados nos debates judiciários.

2) Os Países da União reservam-se igualmente a faculdade de estabelecer nas suas leis internas as condições em que as conferências, alocuções, sermões e outras obras da mesma natureza, pronunciadas em público, poderão ser reproduzidas pela imprensa, transmitidas pelo rádio, pelo telégrafo para o público e constituir objeto de comunicações públicas mencionadas no artigo 11 bis 1) da presente Convenção, quando tal utilização é justificada pela finalidade da informação a ser atingida.

3) Todavia, o autor tem o direito exclusivo de reunir em coleção as suas obras mencionadas nos parágrafos anteriores. 


\begin{abstract}
ARTIGO 3
1) São protegidos por força da presente Convenção:

a) os autores nacionais de um dos países unionistas, quanto às suas obras, publicadas ou não;

b) os autores não nacionais de um dos países unionistas, quanto às obras que publicarem pela primeira vez num desses países ou simultaneamente em um país estranho à União e num país da União.
\end{abstract}

2) Os autores não nacionais de um dos países da União mas que têm sua residência habitual num deles são, para a aplicação da presente Convenção, assimilados aos autores nacionais do referido país.

3) Por "obras publicadas" deve-se entender as obras editadas com o consentimento de seus autores, seja qual for o modo de fabricação dos exemplares, contanto que sejam postos à disposição do público em quantidade suficiente para satisfazer-lhe as necessidades, levando-se em conta a natureza da obra. Não constituem publicação a representação de obras dramáticas, dramáticomusicais ou cinematográficas, a execução de obras musicais, a recitação púbica de obras literárias, a transmissão ou a radiodifusão de obras literárias ou artísticas, a exposição de obras de arte e construção de obras de arquitetura.

4) Considera-se publicada simultaneamente em vários países toda e qualquer obra publicada em dois ou mais países dentro de trinta dias a contar da sua primeira publicação.

\title{
ARTIGO 4
}

Por força da presente Convenção, são protegidos, mesmo se as condições previstas no artigo 3 não forem preenchidas,

a) os autores das obras cinematográficas cujo produtor tenha sua sede ou sua residência habitual em um dos países da União;

b) os autores das obras de arquitetura edificadas num país da União ou de obras de arte gráfica ou plástica incorporadas em um imóvel situado em um país da União.

\section{ARTIGO 5}

1) Os autores gozam, no que concerne às obras quanto às quais são protegidos por força da presente Convenção, nos países da União, exceto o de origem da obra, dos direitos que as respectivas leis concedem atualmente ou venham a conceder no futuro aos nacionais, assim como dos direitos especialmente concedidos pela presente Convenção.

2) O gozo e o exercício desses direitos não estão subordinados a qualquer formalidade; esse gozo e esse exercício independentes da existência da proteção no país de origem das obras. Por conseguinte, afora as estipulações da presente Convenção, a extensão da proteção e os meios processuais garantidos ao autor para salvaguardar os seus direitos regulam-se exclusivamente pela legislação do País onde a proteção é reclamada.

3) A proteção no país de origem é regulada pela legislação nacional. Entretanto, quando o autor não pertence ao país de origem da obra quanto à qual é protegido pela presente Convenção ele terá, nesse país, os mesmos direitos que os autores nacionais.

4) Considera-se país de origem:

a) quanto às obras publicadas pela primeira vez num dos países da União este último país; entretanto, se se tratar de obras publicadas simultaneamente em vários países da União que concedam prazos de proteção diferentes, aquele dentre eles cuja lei conceda prazo de proteção menos extenso; 
b) quanto às obras publicadas simultaneamente num país estranho à União e num país da União, este último país;

c) quanto às obras não publicadas ou quanto às obras publicadas pela primeira vez num país estranho à União, sem publicação simultânea num país da União, aquele a que pertence o autor; entretanto,

i) se se tratar de obras cinematográficas cujo produtor tenha sua sede ou sua residência habitual num país da União, o país de origem será este último, e

ii) se se tratar de obras de arquitetura edificadas num país da União ou de obras de artes gráficas e plásticas incorpadas num imóvel situado em um país da União, o país de origem será este último país.

\section{ARTIGO 6}

1) Quando um país estranho à União não proteger de maneira suficiente as obras dos autores pertencentes a qualquer dos países da União, este último poderá restringir a proteção das obras cujos autores pertencem, à data da primeira publicação dessas obras, ao outro país e não têm residência habitual em qualquer país unionista. Se o país da primeira publicação exercer esta faculdade, os outros países da União não serão obrigados a conceder às obras submetidas a este regime especial uma proteção mais ampla do que aquela que lhes é concedida no país da primeira publicação.

2) Nenhuma restrição, determinada por força do parágrafo precedente, deverá prejudicar os direitos que o autor tenha adquirido sobre qualquer obra sua publicada em país unionista antes de entrar em vigor essa restrição.

3) Os Países unionistas que, em virtude do presente artigo, restringirem a proteção dos direitos dos autores, notificá-lo-ão ao Diretor Geral da Organização Mundial da Propriedade Intelectual (abaixo designado "Diretor Geral"), mediante declaração escrita em que se indiquem os países em relação aos quais a porteção se restringe, bem como as restrições a que os direitos dos autores pertencentes a esses países ficam sujeitos. O Diretor-Geral comunicará imediatamente o fato a todos os países da União.

\section{ARTIGO 6 bis}

1) Independentemente dos direitos patrimoniais de autor, e mesmo depois da cessão dos citados direitos, o autor conserva o direito de reivindicar a paternidade da obra e de se opor a toda deformação, mutilação ou a qualquer dano à mesma obra, prejudiciais à sua honra ou à sua reputação.

2) Os direitos reconhecidos ao autor por força do parágrafo 1) antecedente mantêm-se, depois de sua morte, pelo menos até à extinção dos direitos patrimoniais e são exercidos pelas pessoas físicas ou jurídicas a que a citada legislação reconhece qualidade para isso. Entretanto, os países cuja legislação, em vigor no momento da ratificação do presente Ato ou da adesão a ele, não contenha disposições assegurando a proteção depois da morte do autor, de todos os direitos reconhecidos por força do parágrafo 1) acima, reservam-se a faculdade de estipular que alguns desses direitos não serão mantidos depois da morte do autor.

3) Os meios processuais destinados a salvaguardar os direitos reconhecidos no presente artigo regulam-se pela legislação do país onde é reclamada a proteção. 


\begin{abstract}
ARTIGO 7
1) A duração da proteção concedida pela presente Convenção compreende a vida do autor e cinqüenta anos depois da sua morte.

2) Entretanto, quanto às obras cinematográficas, os países da União têm a faculdade de dispor que o prazo da proteção expira cinqüenta anos depois que a obra tiver se tornado acessível ao público com o consentimento do autor, ou que, se tal acontecimento não ocorrer nos cinqüenta anos a contar da realização de tal obra, a duração da proteção expira cinqüenta anos depois da referida realização.

3) Quanto às obras anônimas, ou pseudônimas, a duração concedida pela presente Convenção expira cinqüenta anos após a obra ter se tornado licitamente acessível ao público. No entanto, quando o pseudônimo adotado pelo autor não deixa qualquer dúvida acerca da sua identidade, a duração da proteção é a prevista no parágrafo 1). Se o autor é de uma obra anônima ou pseudônima revela a sua identidade durante o período acima indicado, o prazo de proteção aplicável é o previsto no parágrafo 1). Os países da União não estão obrigados a proteger as obras anônimas ou pseudônimas quanto às quais há razão de presumir-se que o seu autor morreu há cinqüenta anos.
\end{abstract}

4) Os países da União reservam-se, nas suas legislações nacionais, a faculdade de regular a duração da proteção das obras fotográficas e das obras de artes aplicadas protegidas como obras artísticas; entretanto, a referida duração não poderá ser inferior a um período de vinte e cinco anos contados da realização da referida obra.

5) O prazo de proteção posterior à morte do autor e os prazos previstos nos parágrafos 2), 3) e 4) precedentes começam a correr da morte ou da ocorrência mencionada nos referidos parágrafos, mas a duração desses prazos não se conta senão a partir do dia $1^{\circ}$ de janeiro do ano seguinte àquele em que ocorreu a morte ou a ocorrência em questão.

6) Os Países da União têm a faculdade de conceder uma duração de proteção superior àquelas previstas nos parágrafos precedentes.

7) Os Países da União vinculados pelo Ato de Roma da presente Convenção e que concedem, nas suas legislações nacionais em vigor no momento da assinatura do presente Ato, durações inferiores àquelas previstas nos parágrafos precedentes têm a faculdade de conservá-las ao aderir ao presente Ato ou ao ratificá-lo,

casos, a duração será regulada pela lei do país em que a proteção for reclamada; entretanto, a menos que a legislação deste último país resolva de outra maneira, a referida proteção não excederá a duração fixada no país de origem da obra.

\title{
ARTIGO 7 bis
}

As disposições do artigo antecedente são igualmente aplicáveis quando o direito de autor pertence em comum aos colaboradores de uma obra, sob reserva de que os prazos consecutivos à morte do autor sejam calculados a partir da data da morte do último colaborador sobrevivente.

\section{ARTIGO 8}

Os autores de obras literárias e artísticas protegidos pela presente Convenção gozam, durante toda a vigência dos seus direitos sobre as suas obras originais, do direito exclusivo de fazer ou autorizar a tradução das mesmas obras. 


\begin{abstract}
ARTIGO 9
1) Os autores de obras literárias e artísticas protegidas pela presente Convenção gozam do direito exclusivo de autorizar a reprodução destas obras, de qualquer modo ou sob qualquer forma que seja.

2) Às legislações dos países da União reserva-se a faculdade de permitir a reprodução das referidas obras em certos casos especiais, contanto que tal reprodução não afete a exploração normal da obra nem cause prejuízo injustificado aos interesses legítimos do autor.
\end{abstract}

3) Qualquer gravação sonora ou visual é considerada uma reprodução no sentido da presente Convenção.

\title{
ARTIGO 10
}

1) São lícitas as citações tiradas de uma obra já licitamente tornada acessível ao público, com a condição de que sejam conformes aos bons usos e na medida justificada pela finalidade a ser atingida, inclusive as citações de artigos de jornais e coleções periódicas sob forma de resumos de imprensa.

2) Os países da União reservam-se a faculdade de regular, nas suas leis nacionais e nos acordos particulares já celebrados ou a celebrar entre si as condições em que podem ser utilizadas licitamente, na medida justificada pelo fim a atingir, obras literárias ou artísticas a título de ilustração do ensino em publicações, emissões radiofônicas ou gravações sonoras ou visuais, sob a condição de que tal utilização seja conforme aos bons usos.

3) A citações e utilizações mencionadas nos parágrafos antecedentes serão acompanhadas pela menção da fonte do nome do autor, se esse nome figurar na fonte.

\section{ARTIGO 10 bis}

1) Os países da União reservam-se a faculdade de regular nas suas leis internas as condições em que se pode proceder à reprodução na imprensa, ou a radiodifusão ou a transmissão por fio ao público, dos artigos de atualidade de discussão econômica, política, religiosa, publicados em jornais ou revistas periódicas, ou das obras radiofônicas do mesmo caráter, nos casos em que a reprodução, a radiodifusão ou a referida transmissão não sejam expressamente reservadas. Entretanto, a fonte deve sempre ser claramente indicada; a sanção desta obrigação é determinada pela legislação do país em que a proteção é reclamada.

2) Os países da União reservam-se igualmente a faculdade regular nas suas legislações as condições nas quais, por ocasião de relatos de acontecimentos da atualidade por meio de fotografia, cinematografia ou transmissão por fio ao público, as obras literárias ou artísticas vistas ou ouvidas no decurso do acontecimento podem, na medida justificada pela finalidade de informação a atingir, ser reproduzidas e tornadas acessíveis ao público.

\section{ARTIGO 11}

1) Os autores de obras dramáticas, dramático-musicais e musicais gozam do direito exclusivo de autorizar: $1^{\circ}$ a representação e a execução públicas das suas obras, inclusive a representação e a execução públicas por todos os meios e processos; $2^{\circ}$ a transmissão pública por todos os meios da representação e da execução das suas obras. 
2) Os mesmos direitos são concedidos aos autores de obras dramáticas ou dramático-musicais, por toda a duração dos seus direitos sobre a obra original, no que respeita à tradução das suas obras.

\section{ARTIGO 11 bis}

1) Os autores de obras literárias e artísticas gozam do direito exclusivo de autorizar: $1^{0}$ a radiodifusão de suas obras ou a comunicação pública das mesmas obras por qualquer outro meio que sirva para transmitir sem fio os sinais, os sons ou as imagens; $2^{\circ}$ qualquer comunicação pública, quer por fio, quer sem fio, da obra radiodifundida, quando a referida comunicação é feita por um outro organismo que não o da origem; $3^{\circ}$ a comunicação pública, por meio de alto-falante ou por qualquer outro instrumento análogo transmissor de sinais, de sons ou de imagem, da obra radiodifundida.

2) Compete às legislações dos Países da União regular as condições de exercício dos direitos constantes do parágrafo 1) do presente Artigo, mas tais condições só terão um efeito estritamente limitado ao país que as tiver estabelecido. Essas condições não poderão, em caso algum, afetar o direito moral do autor, ou o direito que lhe pertence de receber remuneração equitativa, fixada na falta de acordo amigável, pela autoridade competente.

3) Salvo estipulação em contrário, as autorizações concedidas nos termos do parágrafo 1) do presente Artigo não implicam autorização de gravar, por meio de instrumentos que fixam os sons ou as imagens, as obras radiodifundidas. Entretanto, os países da União reservam-se a faculdade de determinar nas suas legislações nacionais o regime das gravações efêmeras realizadas por um organismo de radiodifusão pelos seus próprios meios e para as suas emissões. Essas legislações poderão autorizar a conservação de tais gravações em arquivos oficiais atendendo ao seu caráter excepcional de documentação.

\section{ARTIGO 11 ter}

1) Os autores de obras literárias gozam do direito exclusivo de autorizar: $1^{\circ}$ a recitação pública de suas obras, inclusive a recitação pública por todos os meios ou processos: $2^{\circ}$ a transmissão pública por todos os meios da recitação de suas obras.

2) Os mesmos direitos são concedidos aos autores de obras literárias durante toda a duração de seus direitos sobre a obra original, no que respeita à tradução de suas obras.

\section{ARTIGO 12}

Os autores de obras literárias ou artísticas gozam do direito exclusivo de autorizar as adaptações, arranjos e outras transformações das mesmas obras.

\section{ARTIGO 13}

1) Cada país da União pode, no que lhe diz respeito, estabelecer reservas e condições relativas ao direito do autor de uma obra musical e do autor da letra cuja gravação juntamente com a obra musical já foi autorizada por este último, de autorizar a gravação sonora da referida obra musical, eventualmente com a letra; mas todas as reservas e condições desta natureza só terão um efeito estritamente limitado ao País que as tiver estabelecido e não poderão em caso algum afetar o direito que tem o autor de receber remuneração equitativa, fixada, na falta de acordo amigável, pela autoridade competente. 
2) As gravações de obras musicais que tenham sido realizadas num País da União nos termos do artigo 13.3 das Convenções assinadas em Roma a 2 de junho de 1928 e em Bruxelas a 26 de junho de 1948 poderão, naquele país, constituir objeto de reproduções sem o consentimento do autor da obra musical até a expiração de um período de dois anos contados da data na qual o referido país fica vinculado pelo presente Ato.

3) As gravações feitas nos termos dos parágrafos 1) e 2) do presente artigo e importadas, sem autorização das partes interessadas, para um país onde não sejam lícitas poderão ser ali apreendidas.

\section{ARTIGO 14}

1) Os autores de obras literárias ou artísticas têm o direito exclusivo de autorizar: $1^{\circ}$ - a adaptação e reprodução cinematográfica dessa obra e a distribuição das obras assim adaptadas ou reproduzidas; $2^{\circ}$ - a representação e a execução públicas das obras assim adaptadas ou reproduzidas.

2) A adaptação, sob qualquer outra forma artística, das realizações cinematográficas extraídas de obras literárias ou artísticas fica submetida, sem prejuízo da autorização dos seus autores à autorização dos autores das obras originais.

3) As disposições do artigo 13.1) não são aplicáveis.

\section{ARTIGO 14 bis}

1) Sem prejuízo dos direitos do autor de qualquer obra que poderia ter sido adaptada ou reproduzida, a obra cinematográfica é protegida como uma obra original. O titular do direito de autor sobre a obra cinematográfica goza dos mesmos direitos que o autor de uma obra original, inclusive os direitos mencionados no artigo precedente.

2) a) A determinação dos titulares do direito de autor sobre a obra cinematográfica é reservada à legislação do país em que a proteção é reclamada.

b) Entretanto, nos países da União nos quais a legislação reconhece entre estes titulares os autores das contribuições prestadas à realização da obra cinematográfica, estes últimos, e se comprometeram a prestar tais contribuições, não poderão, salvo estipulação contrária ou particular, se opor à reprodução, à distribuição, à representação e à execução públicas, à transmissão por fio ao público, à radiodifusão, à comunicação ao público, à colocação de legendas e à dublagem dos textos, da obra cinematográfica.

c) A questão de saber se a forma de compromisso acima referido deve, para a aplicação da alínea

b) precedente, ser ou não um contrato escrito ou um ato escrito equivalente é regulada pela legislação do país da União em que o produtor da obra cinematográfica tem sua sede ou sua residência habitual. Todavia, à legislação dos países da União onde a proteção é reclamada fica reservada a faculdade de dispor que tal compromisso deve ser um contrato escrito ou um ato escrito equivalente. Os países que fazem uso desta faculdade deverão notificá-lo ao Diretor-Geral mediante uma declaração escrita que será imediatamente comunicada por este último a todos os outros países da União.

d) Por "estipulação contrária ou particular" deve entender-se toda condição restritiva que possa acompanhar o referido compromisso.

3) A menos que a legislação nacional decida de outra maneira, a disposição do parágrafo 2) b) acima não são aplicáveis nem aos autores dos argumentos, dos diálogos e das obras musicais, criados para a realização da obra cinematográfica, nem ao realizador principal da mesma. Entretanto, os Países da União cuja legislação não contenha disposições prevendo a aplicação do 
parágrafo 2) b) precitado ao referido realizador deverão notificá-lo ao Diretor-Geral mediante uma declaração escrita que será imediatamente comunicada por este último a todos os outros países da União.

\section{ARTIGO 14 ter}

1) Quanto às obras de arte originais e aos manuscritos originais dos escritores e compositores, o autor - ou, depois da sua morte, as pessoas físicas ou jurídicas como tais qualificadas pela legislação nacional - goza de um direito inalienável de ser interessado nas operações de venda de que a obra for objeto depois da primeira cessão efetuada pelo autor.

2) A proteção prevista no parágrafo anterior só é exigível em cada país unionista se a legislação do país a que pertence o autor admite essa proteção e na medida em que o permite a legislação do país onde tal proteção é reclamada.

3) As modalidades e as taxas da percepção são determinadas em cada legislação nacional.

\section{ARTIGO 15}

1) Para que os autores das obras literárias e artísticas protegidos pela presente Convenção sejam, até prova em contrário, considerados como tais e admitidos em consequência, perante os tribunais dos países da União, a proceder judicialmente contra os contrafatores, basta que os seus nomes venham indicados nas obras pela forma usual. O presente parágrafo é aplicável mesmo quando os nomes são pseudônimos, desde que os pseudônimos adotados não deixem quaisquer dúvidas acerca da identidade dos autores.

2) Presume-se produtor da obra cinematográfica, salvo prova em contrário, a pessoa física ou jurídica cujo nome é indicado na referida obra na forma habitual.

3) Quanto às obras anônimas, e às pseudônimas que não sejam as mencionadas no parágrafo 1) anterior, o editor cujo nome vem indicado na obra é, sem necessidade de outra prova, considerado representante do autor; nesta qualidade tem poderes para salvaguardar e fazer valer os direitos deste. A disposição do presente parágrafo deixa de aplicar-se quando o autor revelou a sua identidade e justificou a sua qualidade.

4) a) Quanto às obras não publicadas cujo autor é de identidade desconhecida, mas, segundo tudo leva a presumir, nacional de um país da União, é reservada à legislação desse país a faculdade de designar a autoridade competente para representar esse autor e com poderes para salvaguardar e fazer valer os direitos do mesmo nos países da União.

b) Os Países da União, que, por força desta disposição, procederem a tal designação, notificá-lo-ão ao Diretor-Geral mediante uma declaração escrita em que serão indicadas todas as informações relativas à autorização assim designada. O Diretor-Geral comunicará imediatamente a referida declaração a todos os outros países da União.

\section{ARTIGO 16}

1) Toda obra contrafeita pode ser apreendida nos países da União onde a obra original tem direito à proteção legal.

2) As disposições do parágrafo precedente são igualmente aplicáveis às reproduções provenientes de um país onde a obra não é protegida ou deixou de sê-lo.

3) A apreensão efetua-se de acordo com a legislação interna de cada país. 


\begin{abstract}
ARTIGO 17
As disposições da presente Convenção não podem prejudicar, seja no que for, o direito que tem o Governo de qualquer dos Países da União de permitir, vigiar ou proibir, por medidas de legislação ou de polícia interna, a circulação, a representação ou a exposição de qualquer obra ou produção a respeito das quais a autoridade competente julgue necessário exercer esse direito.
\end{abstract}

\title{
ARTIGO 18
}

1) A presente Convenção aplica-se a todas as obras que na data da entrada em vigor deste instrumento, não caíram ainda no domínio público nos seus países de origem por ter expirado o prazo de proteção.

2) Todavia, se uma obra, por ter expirado o prazo de proteção que lhe era anteriormente reconhecido, caiu no domínio público no país onde a proteção é reclamada, não voltará a ser ali protegida.

3) A aplicação deste principio efetuar-se-á de acordo com as estipulações contidas nas convenções especiais já celebradas ou a celebrar neste sentido entre países da União. Na falta de semelhantes estipulações, os países respectivos regularão, cada qual no que lhe disser respeito, as modalidades relativas a tal aplicação.

4) As disposições precedentes aplicam-se igualmente no caso de novas adesões à União e quando a proteção for ampliada por aplicação do artigo $7^{\circ}$ ou por abandono de reservas.

\section{ARTIGO 19}

As disposições da presente Convenção não impedem que se reivindique a aplicação de disposições mais amplas que venham a ser promulgadas na legislação de qualquer país unionista.

\section{ARTIGO 20}

Os governos dos países da União reservam-se o direito de celebrar entre si acordos particulares, desde que tais acordos concedam aos autores direitos mais extensos do que aqueles conferidos pela Convenção ou contenham estipulações diferentes não contrárias à mesma. As disposições dos acordos existentes que correspondem às condições acima indicadas continuam em vigor.

\section{ARTIGO 21}

1) Figuram em Anexo disposições especiais relativas aos países em via de desenvolvimento.

2) Sob reserva das disposições do artigo 28.1) b), o Anexo forma parte integrante do presente Ato.

\section{ARTIGO 22}

1) a) A União tem uma Assembléia composta dos países da União vinculados pelos artigos 22 a 26.

b) O Governo de cada país é representado por um delegado, que pode ser assessorado por suplentes, conselheiros e peritos.

c) Os ônus de cada delegação são suportados pelo Governo que a designou. 
2) a) A Assembléia:

i) trata de todas as questões relativas à manutenção e ao desenvolvimento da União e à aplicação da presente Convenção;

ii) dá ao "Bureau international de la ptopriété intellectuelle" (abaixo denominado "o Bureau Internacional"), mencionado na Convenção que instituiu a organização Mundial da Propriedade Intelectual (abaixo denominada "a Organização"), diretrizes relativas à preparação das conferências de revisão, levando devidamente em conta as observações dos países da União que não são vinculados pelos artigos 22 a 26;

iii) examina e aprova os relatórios e as atividades do Diretor-Geral da Organização relativos à União e lhe dá todas as diretrizes úteis referentes às questões da competência da União;

iv) elege os membros da Comissão Executiva da Assembléia;

v) examina e aprova os relatórios e as atividades de sua Comissão Executiva e lhe dá diretrizes;

vi) baixa o programa, adota o orçamento trienal da União e aprova suas contas de encerramento;

vii) adota o regime financeiro da União;

viii) cria as comissões de peritos e grupos de trabalho que julgar úteis à realização dos objetivos da União;

ix) decide quais os países não-membros da União e quais as organizações intergovernamentais e internacionais não-governamentais que podem ser admitidas nas suas reuniões na qualidade de observadores;

xi) empreende qualquer outra artigos 22 a 26 ;

xi) empreende qualquer outra ação apropriada a fim de alcançar os objetivos da União;

xii) executa quaisquer outras tarefas decorrentes da presente Convenção;

xiii) exerce, com a ressalva de que os aceite, os direitos que lhe são conferidos pela convenção que instituiu a Organização.

b) Em questões que interessem igualmente outras Uniões administradas pela Organização, a Assembléia estatui após tomar conhecimento do parecer da Comissão de Coordenação da Organização.

3) a) Cada país membro da Assembléia dispõe de um voto.

b) O "quórum" é constituído pela metade dos países membros da Assembléia;

c) Não obstante as disposições da alínea b), se por ocasião de uma sessão, o número dos países representados for inferior à metade mas igual ou superior a um terço dos países membros da Assembléia, esta poderá tomar decisões; entretanto, as decisões da Assembléia, com exceção daquelas relativas ao processamento dos trabalhos, só se tornarão executórias quando as condições enunciadas abaixo forem cumpridas. O Bureau Internacional comunica as referidas decisões aos países membros da Assembléia que não estavam representados, convidando-os a expressar por escrito, num prazo de três meses contados da data da referida comunicação seu voto ou sua abstenção. Se expirado este prazo, o número dos países que assim exprimiram seu voto ou sua abstenção for pelo menos igual ao número de países que faltavam para que o "quórum" fosse alcançado por ocasião da sessão, as referidas decisões tornar-se-ão executórias, - contanto que se mantenha ao mesmo tempo a maioria necessária.

d) Ressalvadas as disposições do artigo 26.2), as decisões da Assembléia são tomadas por maioria de dois terços dos votos expressos.

e) A abstenção não é computada como voto.

f) Um delegado não pode representar senão um só país e somente pode votar em nome dele.

g) Os países da União que não são membros da Assembléia são admitidos à suas reuniões na qualidade de observadores. 
4) a) A Assembléia se reúne uma vez em cada três anos em sessão ordinária, mediante convocação feita pelo Diretor-Geral e, salvo casos excepcionais, durante o mesmo período e no mesmo lugar que a Assembléia Geral da Organização.

b) A Assembléia se reúne em sessão extraordinária mediante convocação feita pelo Diretor-Geral, a pedido da Comissão Executiva ou de um quarto dos países membros da Assembléia.

5) A Assembléia adotará seu próprio regimento interno.

\section{ARTIGO 23}

1) A Assembléia tem uma Comissão Executiva.

2) a) A Comissão Executiva é composta dos países eleitos pela Assembléia dentre os países membros desta última. Além disso, o país em cujo território a Organização tem sua sede dispõe, ex offício, de um lugar na Comissão, ressalvadas as disposições do artigo 25.7) b).

b) O Governo de cada país membro da Comissão Executiva é representado por um delegado que pode ser assessorado por suplentes, conselheiros e peritos;

c) As despesas de cada delegação são custeadas pelo Governo que a designou.

3) O número dos países membros da Comissão Executiva corresponde à quarta parte do número dos países membros da Assembléia. No cálculo das vagas a preencher, o resto que fica depois da divisão por quatro não é tomado em consideração.

4) Por ocasião da eleição dos membros da Comissão Executiva, a Assembléia levará em conta uma distribuição geográfica equitativa e a necessidade de estarem os países que são partes nos Acordos Especiais que possam ser estabelecidos em relação com a União entre os países que constituem a Comissão Executiva.

5) a) Os membros da Comissão Executiva permanecem nas suas funções a partir do encerramento da sessão da Assembléia no decurso da qual foram eleitos até o término da sessão ordinária seguinte da Assembléia.

b) Os membros da Comissão Executiva são reelegíveis no limite máximo de dois terços deles.

c) A Assembléia regulamenta as modalidades da eleição e da eventual reeleição dos membros da Comissão Executiva.

6) a) A Comissão Executiva:

i) prepara o projeto de ordem do dia da Assembléia;

ii) submete à Assembléia propostas relativas aos projetos de programa e de orçamento trienal da União preparados pelo Diretor-Geral;

iii) dá seu parecer, nos limites do programa e do orçamento trienal, sobre os programas e os orçamentos anuais preparados pelo Diretor-Geral;

iv) submete à Assembléia, com os comentários apropriados, os relatórios periódicos do DiretorGeral e os relatórios anuais de verificação das contas;

v) toma todas as medidas úteis com vistas à execução do programa da União pelo Diretor-Geral, nos termos das decisões da Assembléia e levando em conta as circunstâncias sobrevindas entre duas sessões ordinárias da referida Assembléia;

vi) se desincumbe de quaisquer outras tarefas que lhe sejam atribuídas no âmbito da presente Convenção. 
b) Relativamente às questões que interessem igualmente outras Uniões administradas pela Organização, a Comissão Executiva estatui depois de tomar conhecimento do parecer do Conselho de Coordenação da Organização.

7) a) A Comissão Executiva reúne-se uma vez por ano em sessão ordinária, mediante convocação feita pelo Diretor-Geral, na medida do possível, durante o mesmo período e no mesmo lugar que a Comissão de Coordenação da Organização.

b) A Comissão Executiva se reúne em sessão extraordinária mediante convocação feita pelo Diretor-Geral, seja por iniciativa deste último, seja a pedido de seu presidente ou de um quarto de seus membros.

8) a) Cada país membro da Comissão Executiva dispõe de um voto.

b) A metade dos países membros da Comissão Executiva constitui o "quórum".

c) As decisões são tomadas por maioria simples dos votos expressos.

d) A abstenção não pode ser considerada como voto.

e) Um delegado não pode representar senão um só País e somente pode votar em nome dele.

9) Os países da União que não sejam membros da Comissão Executiva são admitidos às suas reuniões na qualidade de observadores.

10) A Comissão Executiva adotará seu próprio regimento interno.

\section{ARTIGO 24}

1) a) as tarefas administrativas que incumbem à União são asseguradas pelo Bureau Internacional, que sucede ao Bureau da União unido com o Bureau da União instituído pela Convenção Internacional para a Proteção da Propriedade Industrial.

b) o Bureau Internacional encarrega-se especialmente do secretariado dos diversos órgãos da União.

c) O Diretor-Geral da Organização é o mais alto funcionário da União e a representa.

2) O Bureau Internacional reúne e publica, as informações relativas à proteção do direito de autor. Cada País da União comunica, logo que possível, ao Bureau Internacional o texto de qualquer nova lei assim como de quaisquer textos oficiais relativos à proteção do direito de autor.

3) O Bureau Internacional publica um periódico mensal.

4) O Bureau Internacional fornece a qualquer país da União, a seu pedido, informações sobre as questões relativas à proteção do direito do autor.

5) O Bureau Internacional realiza estudos e fornece serviços destinados a facilitar a proteção do direito de autor.

6) O Diretor-Geral e qualquer membro do pessoal por ele designado participam, sem direito de voto, de todas as reuniões da Assembléia, da Comissão Executiva e qualquer outra comissão de peritos ou grupo de trabalho. O Diretor-Geral ou um membro do pessoal designado por ele é, ex officio, secretário dos referidos órgãos. 
7) a) O Bureau Internacional, em conformidade com as diretrizes da Assembléia e em cooperação com a Comissão Executiva, prepara as conferências de revisão das disposições da Convenção que não sejam aquelas compreendidas nos artigos 22 a 26.

b) O Bureau Internacional pode consultar órgãos intergovernamentais e internacionais nãogovernamentais relativamente à preparação das conferências de revisão.

c) O Diretor-Geral e as pessoas designadas por ele participam, sem direito de voto, das deliberações dessas conferências.

8) O Bureau Internacional executa quaisquer outras tarefas que lhe sejam atribuídas.

\section{ARTIGO 25}

1) a) A União tem um orçamento.

b) O orçamento da União abrange as receitas e as despesas próprias da União, sua contribuição para o orçamento das despesas comuns às Uniões assim como, eventualmente, a quantia posta à disposição do orçamento da Conferência da Organização.

c) Consideram-se despesas comuns às Uniões as despesas que não são exclusivamente atribuídas à União mas igualmente a uma ou várias outras Uniões administradas pela Organização. A parte da União nessas despesas comuns é proporcional ao interesse que ditas despesas apresentam para ela.

2) O orçamento da União é estabelecido levando-se em conta as exigências de coordenação com os orçamentos das outras Uniões administradas pela Organização.

3) O orçamento da União é financiado com os seguintes recursos:

i) as contribuições dos países da União;

ii) as taxas e quantias devidas pelos serviços prestados pelo Bureau Internacional por conta da União;

iii) o produto da venda das publicações do Bureau Internacional relativas à União e os direitos correspondentes a estas publicações;

iv) os donativos, legados e subvenções;

v) os aluguéis, juros e outras rendas diversas.

4) a) A fim de determinar sua parte de contribuição ao orçamento, cada país da União é incluindo numa classe e paga suas contribuições anuais com base em um número de unidades fixado como segue:

\begin{tabular}{|c|c|}
\hline 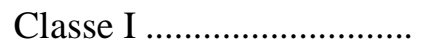 & \\
\hline Classe II ............................. & \\
\hline 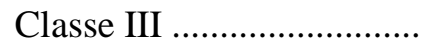 & \\
\hline Classe IV ............................. & \\
\hline 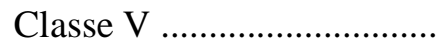 & \\
\hline Classe VI ............................... & \\
\hline Classe VII ............................... & \\
\hline
\end{tabular}

b) A menos que já o tenha feito antes, cada país declarará, no momento do depósito de seu instrumento de ratificação ou de adesão, em qual das mencionadas classes deseja ser incluído. Pode mudar de classe. Se escolher uma classe inferior, deve comunicar o fato à Assembléia por ocasião de uma de suas sessões ordinárias. Tal mudança entrará em vigor no início do ano civil seguinte à referida sessão.

c) A contribuição anual de cada país consiste numa quantia cuja relação à soma total das contribuições anuais, ao orçamento da União, de todos os países é a mesma que a relação entre o 
número de unidades da classe na qual está incluído e o número total das unidades do conjunto dos países.

d) As contribuições vencem no dia $1^{\circ}$ de janeiro de cada ano.

e) Um país atrasado no pagamento de suas contribuições não pode exercer seu direito de voto, em qualquer dos órgãos da União do qual é membro, se o montante de seus atrasados é igual ou superior ao das contribuições das quais é devedor pelos dois anos completos esgotados. Entretanto, qualquer um desses órgãos pode permitir que tal país continue exercendo seu direito de voto no órgão enquanto julgar que o atraso resulta de circunstâncias excepcionais e inevitáveis.

f) No caso em que o orçamento não haja sido adotado antes do início do novo exercício, continuará a ser aplicado, conforme as modalidades previstas pelo regimento financeiro, o orçamento do ano anterior.

5) O montante das taxas e quantias por serviços prestados pelo Bureau Internacional por conta da União é fixado pelo Diretor-Geral, que informa sobre isso a Assembléia e a Comissão Executiva.

6) a) A União possui um fundo de giro constituído por um pagamento único, efetuado por cada país da União. Se o fundo se torna insuficiente, a Assembléia decide seu aumento.

b) $\mathrm{O}$ montante do pagamento inicial de cada país para o citado fundo ou de sua participação no aumento deste último é proporcional à contribuição desse país para o ano no curso do qual se constitui o fundo ou se resolveu o aumento.

c) A proporção e as modalidades de pagamento são determinadas pela Assembléia, mediante proposta do Diretor Geral e após parecer da Comissão de Coordenação da Organização.

7) a) O Acordo de sede concluído com o país em cujo território a Organização tem sua sede prevê que, se o fundo de giro for insuficiente, este país concederá adiantamentos. O montante desses adiantamentos e as condições nas quais são concedidos constituem objeto, em cada caso, de acordos separados entre o país em questão e a Organização. Enquanto tal país tiver obrigação de conceder adiantamentos, disporá ele, ex offício, de uma cadeira na Comissão Executiva.

b) O país mencionado na alínea a) e a Organização têm, cada um, o direito de denunciar o compromisso de conceder adiantamentos, mediante notificação por escrito. A denúncia entra em vigor três anos depois do fim do ano no curso do qual ela foi notificada.

8) A verificação das contas é assegurada, segundo as modalidades previstas pelo regimento financeiro, por um ou vários países da União ou por técnicos de controle externo, que são, com o consentimento deles, designados pela Assembléia.

\section{ARTIGO 26}

1) Propostas de modificação dos artigos 22, 23, 24 e 25 e do presente artigo podem ser apresentadas por qualquer país membro da Assembléia, pela Comissão Executiva ou pelo DiretorGeral. Estas propostas são comunicadas por este último aos países membros da Assembléia seis meses pelo menos antes de serem submetidas à Assemblia para exame.

2) Toda modificação dos artigos mencionados no parágrafo 1) é adotada pela Assembléia. A adoção requer três quartos dos votos expressos; entretanto, qualquer modificação do artigo 22 e do presente parágrafo requer quatro quintos dos votos expressos.

3. Qualquer modificação dos artigos mencionados na alínea 1) entra em vigor um mês depois do recebimento pelo Diretor-Geral das notificações escritas de aceitação, efetuada em conformidade com suas respectivas normas constitucionais, de três quartos dos países que eram membros da Assembléia no momento em que a notificação foi adotada. Qualquer modificação dos referidos 
artigos assim aceita vincula todos os países que sejam membros da Assembléia no momento em que a modificação entra em vigor ou que se tornam membros numa data ulterior; entretanto, qualquer modificação que aumente as obrigações financeiras dos países da União não vincula senão aqueles dentre eles que notificaram sua aceitação de tal modificação.

\section{ARTIGO 27}

1) A presente Convenção será submetida a revisões a fim de nela se introduzirem melhoramentos que possam aperfeiçoar o sistema da União.

2) Para tal efeito, realizar-se-ão conferências, sucessivamente, num dos países da União, entre os delegados dos referidos países.

3) Sem prejuízo das disposições do artigo 26 aplicáveis à modificação dos artigos 22 a 26, qualquer revisão do presente Ato, inclusive o Anexo, requer a unanimidade dos votos expressos.

\section{ARTIGO 28}

1) a) Qualquer dos países da União que tenha assinado o presente Ato pode ratificá-lo e, se não o tiver assinado, pode a ele aderir. Os instrumentos de ratificação ou de adesão são depositados junto ao Diretor-Geral.

b) Qualquer dos países da União pode declarar no seu instrumento de ratificação ou de adesão que sua ratificação ou sua adesão não é aplicável aos artigos 1 a 21 e ao Anexo; entretanto, se tal país já fez uma declaração de acordo com o artigo VI. 1) do Anexo, só pode declarar no referido instrumento que sua ratificação ou sua adesão não se aplica aos artigos 1 a 20.

c) Qualquer dos países da União que, de acordo com a alínea b), excluiu dos efeitos de sua ratificação ou de sua adesão as disposições mencionadas na referida alínea pode, a qualquer momento posterior, declarar que estende os efeitos de sua ratificação ou de sua adesão a estas disposições. Tal declaração é depositada junto ao Diretor-Geral.

2) a) Os artigos 1 a 21 e o Anexo entram em vigor três meses depois que as duas condições seguintes foram preenchidas:

i) cinco Países da União pelo menos ratificaram o presente Ato ou a ele aderiram sem fazer declaração segundo o parágrafo 1 b);

ii) a Espanha, os Estados Unidos da América, a França e o Reino Unido da Grã-Bretanha e Irlanda do Norte ficaram vinculados pela Convenção universal sobre o direito de autor, tal qual foi revista em Paris a 24 de julho de 1971.

b) A entrada em vigor mencionada na alínea a) é efetiva em relação aos países da União que, três meses pelo menos antes da referida entrada em vigor, depositaram instrumentos de ratificação ou de adesão que não contêm declaração segundo o parágrafo 1) b).

c) Em relação a qualquer dos países da União ao qual a alínea b) não é aplicável e que ratifica o presente Ato ou a ele adere sem fazer declaração segundo o parágrafo 1) b), os artigos 1 a 21 e o Anexo entram em vigor três meses depois da data em que o Diretor-Geral notificou o depósito do instrumento de ratificação de adesão em causa, a menos que uma data posterior tenha sido indicada no instrumento depositado. Nesse último caso, os artigo 1 a 21 e o Anexo entram em vigor em relação a esse país na data assim indicada.

d) As disposições das alíneas a) a c) não afetam a aplicação do artigo VI do Anexo.

3) Em relação a qualquer dos países da União que ratifique o presente Ato ou a ele adira com ou sem declaração segundo o parágrafo 1) b), os artigos 22 a 38 entram em vigor três meses depois da 
data em que o Diretor-Geral houver notificado o depósito do instrumento de ratificação ou de adesão em causa, a menos que uma data posterior tenha sido indicada no instrumento depositado. Neste último caso, os artigos 22 a 38 entram em vigor em relação a esse país na data assim indicada.

\section{ARTIGO 29}

1) Qualquer país estranho à União pode aderir ao presente Ato e tornar-se, assim, parte na presente Convenção e membro da União. Os instrumentos de adesão são depositados junto ao Diretor-Geral.

2) a) Ressalvada a alínea b), a presente Convenção entra em vigor em relação a qualquer país estranho à União três meses depois da data em que o Diretor-Geral notificou o depósito de seu instrumento de adesão, a menos que uma data posterior tenha sido indicada no instrumento depositado. Neste último caso, a presente Convenção entra em vigor em relação a esse país na data assim indicada.

b) Se a entrada em vigor em aplicação da alínea a) precede a entrada em vigor dos artigos 1 a 21 e do Anexo com aplicação do artigo 28.2) a), o referido país será vinculado, no intervalo, pelos artigos 1 a 20 do Ato de Bruxelas da presente Convenção que passam a substituir os artigos 1 a 21 e o Anexo.

\section{ARTIGO 29 bis}

A ratificação do presente Ato ou a adesão a este Ato por qualquer país não vinculado pelos artigos 22 a 38 do Ato de Estocolmo da presente Convenção equivale para o único fim de poder-se aplicar o artigo 14.2) da Convenção que instituiu a Organização, à ratificação do Ato de Estocolmo ou à adesão a este Ato com a limitação prevista pelo artigo 28.1) b) I) de tal Ato.

\section{ARTIGO 30}

1) Ressalvadas as exceções permitidas pelo parágrafo 2) do presente artigo, pelo artigo 28.1) b), pelo artigo 33.2), assim como pelo Anexo, a ratificação ou a adesão importa, de pleno direito, em acessão a todas as cláusulas e admissão a todas as vantagens estipuladas pela presente Convenção.

2) a) Qualquer país da União que ratifica o presente Ato ou a ele adere pode, sem prejuízo do artigo V.2) do Anexo, conservar o beneficio das ressalvas que formulou anteriormente, com condição de declará-lo ao fazer o depósito de seu instrumento de ratificação ou de adesão.

b) Qualquer país estranho à União pode declarar, ao aderir à presente Convenção, e em seu prejuízo do artigo V.2) do Anexo, que entende substituir, provisoriamente pelo menos, ao artigo 8 do presente Ato, relativo ao direito de tradução as disposições do artigo 5 da Convenção da União de 1886, completada em Paris em 1806, ficando bem entendido que estas disposições visam somente a tradução numa língua de uso geral no referido país. Sem prejuízo do artigo I.6) b) do Anexo, qualquer país tem a faculdade de aplicar, relativamente ao direito de tradução das obras que têm como país de origem um país que faça uso de tal ressalva, uma proteção equivalente à concedida por este último país.

c) Qualquer país pode, em qualquer momento, retirar as referidas ressalvas, mediante notificação dirigida ao Diretor-Geral.

\section{ARTIGO 31}

1) Qualquer país pode declarar em seu instrumento de ratificação ou de adesão, ou pode informar ao Diretor-Geral mediante notificação escrita em qualquer momento posterior, que a presente 
Convenção é aplicável à totalidade ou a parte dos territórios, designados na declaração ou na notificação, pelos quais assume a responsabilidade das relações exteriores.

2) Qualquer país que tenha feito tal declaração ou efetuado tal notificação pode, em qualquer momento, notificar ao Diretor-Geral que a presente Convenção deixa de ser aplicável à totalidade ou a parte dos referidos territórios.

3) a) Qualquer declaração feita por força do parágrafo 1) entra em vigor na mesma data em que a ratificação ou a adesão em cujo instrumento ela foi incluída, e qualquer notificação efetuada por força deste parágrafo entra em vigor três meses depois de sua notificação pelo Diretor-Geral.

b) Qualquer notificação efetuada por força do parágrafo 2) entra em vigor doze meses depois de seu recebimento pelo Diretor-Geral.

4) O presente artigo não poderá ser interpretado como acarretando o reconhecimento ou a aceitação tácita por qualquer dos países da União da situação de fato de qualquer território ao qual a presente Convenção é tornada aplicável por um outro pais da União por força de uma declaração feita em aplicação do parágrafo 1).

\section{ARTIGO 32}

1) O presente Ato substitui, nas relações entre os países da União, e na medida em que se aplica, a Convenção de Berna de 9 de setembro de 1886 e os Atos que revisão subsequentes. Os Atos que vigoravam anteriormente continuam sendo aplicáveis, em sua totalidade ou na medida em que o presente Ato não os substitui por força da frase anterior, nas relações com os países da União que não ratifiquem o presente Ato ou que a ele não adiram.

2) Os países estranhos à União que passem a ser partes no presente Ato aplicá-lo-ão, sem prejuízo das disposições do parágrafo 3), relativamente a qualquer país da União que não seja parte deste Ato, ou que, sendo parte do mesmo, tenha feito a declaração prevista no artigo 28.1) b). Os referidos países admitirão que tal país, em suas relações com eles:

i) aplique as disposições do Ato mais recente do qual seja parte e,

ii) sem prejuízo do disposto no artigo I.6) do Anexo, tenha a faculdade de adaptar a proteção no nível previsto pelo presente Ato.

3) Os países que invocaram o benefício de qualquer das faculdades previstas no Anexo podem aplicar as disposições do Anexo que dizem respeito à faculdade ou às faculdades cujo beneficio invocaram, em suas relações com qualquer país da União que não esteja vinculado pelo presente Ato, com a condição de que este último país tenha aceito a aplicação de tais disposições.

\section{ARTIGO 33}

1) Todos os litígios entre dois ou mais países da União, que digam respeito à interpretação ou a aplicação da presente Convenção e que não sejam solucionadas por via de negociações, serão submetidos à Corte Internacional de Justiça por qualquer dos países em causa, mediante petição redigida em conformidade com o Estatuto da Corte, salvo se os países em causa acordarem em qualquer outra forma de solução. O Bureau Internacional será informado pelo país requerente do litígio submetido ao Tribunal e disso dará conhecimento aos outros países da União.

2) No momento em que firmar o presente Ato ou depositar seu instrumento de ratificação ou de adesão, qualquer país poderá declarar que não se considera vinculado pelas disposições do parágrafo 1). As disposições do parágrafo 1) não são aplicáveis no que diz respeito a qualquer litígio entre tal país e os demais países da União. 
3) Qualquer país que tenha feito uma declaração segundo o disposto no parágrafo 2) pode retirá-la, em qualquer tempo, mediante notificação dirigida ao Diretor-Geral.

\section{ARTIGO 34}

1) Sem prejuízo do disposto no artigo 29 bis, depois da entrada em vigor dos artigos 1 a 21 e do Anexo, nenhum país pode aderir a Atos anteriores à presente Convenção ou ratifica-los.

2) A partir da entrada em vigor dos artigos 1 a 21 e do Anexo, nenhum país pode fazer declaração por força do disposto no artigo 5 do Protocolo relativo aos países em vias de desenvolvimento, anexo ao Ato de Estocolmo.

\section{ARTIGO 35}

1) A presente Convenção manter-se-á em vigor por tempo indeterminado.

2) Qualquer país pode denunciar o presente Ato mediante notificação dirigida ao Diretor-Geral. Esta denúncia implica também em denúncia de todos os Atos anteriores e não produzirá efeito senão com referência ao país que a tenha apresentado, permanecendo a Convenção em vigor e executiva com relação aos outros países da União.

3) A denúncia produzirá efeito um ano depois da data em que o Diretor-Geral recebeu a notificação.

4) O direito de denúncia previsto no presente artigo não poderá ser exercido por qualquer país antes de expirado o prazo de cinco anos a contar da data em que tal país se tenha tornado membro da União.

\section{ARTIGO 36}

1) Todo país parte na presente Convenção se compromete a adotar, de conformidade com sua Constituição, as medidas necessárias para assegurar a aplicação da presente Convenção.

2) Entende-se que, no momento em que um país se vincula pela presente Convenção, deve estar em condições, de conformidade com sua legislação interna, de aplicar as disposições da presente Convenção.

\section{ARTIGO 37}

1) a) O presente Ato é assinado em um único exemplar nas línguas inglesa e francesa, e sem prejuízo do parágrafo 2), é depositado junto ao Diretor-Geral.

b) Textos oficiais são elaborados pelo Diretor Geral, depois de consultados os Governos interessados, nas línguas alemã, árabe, espanhola, italiana e portuguesa, e nas outras línguas que poderão ser indicadas pela Assembléia.

c) Em caso de divergência quanto à interpretação dos diversos textos, fará fé o texto francês.

2) O presente Ato permanece aberto a assinatura até 31 de janeiro de 1972. Até esta data, o exemplar mencionado no parágrafo 1) a) será depositado junto ao Governo da República Francesa.

3) O Diretor-Geral transmitirá duas cópias certificadas conforme do texto assinado do presente Ato aos Governos de todos os países da União e, a pedido, ao Governo de qualquer outro país. 
4) O Diretor-Geral fará registrar o presente Ato junto ao Secretariado da Organização das Nações Unidas.

5) O Diretor-Geral notificará aos Governos de todos os países da União as assinaturas, os depósitos de instrumentos de ratificação ou de adesão e de declarações compreendidas nesses instrumentos ou efetuadas em aplicação dos artigos 28.1) c), 30.2) a) e b) 33.2), a entrada em vigor de quaisquer disposições do presente Ato, as notificações de denúncia e as notificações feitas em aplicação dos artigos 30.2) c) 31.1 e 2), 33.3) e 33.1), assim como as notificações mencionadas no Anexo.

\section{ARTIGO 38}

1) Os países da União que não ratificaram o presente Ato ou que não aderiram a ele e que não são vinculados pelos artigos 22 a 26 do Ato de Estocolmo podem exercer, até o dia 26 de abril de 1975, se o desejarem, os direitos previstos pelos referidos artigos, como se fossem por eles vinculados. Qualquer país que deseje exercer os referidos direitos deposita para este fim junto ao Diretor-Geral uma notificação escrita que entra em vigor na data de seu recebimento. Tais países são considerados membros da Assembléia até a referida data.

2) Enquanto todos os países da União não se tiverem tornado membros da Organização, o Bureau Internacional da Organização funcionará igualmente como Secretaria da União e o Diretor-Geral, como Diretor de tal Secretaria.

3) Quando todos os países da União se tiverem tornado membros da Organização, os direitos, obrigações e bens da Secretaria da União passarão para o Bureau Internacional da Organização.

\section{ANEXO}

\section{ARTIGO I}

1) Qualquer país considerado de conformidade com a prática estabelecida na Assembléia Geral das Nações Unidas, como país em via de desenvolvimento, que ratifique o presente Ato, do qual o presente Anexo forma parte integrante, ou que a ele adira, e que, em vista de sua situação econômica e de suas necessidades sociais e culturais, não se considere estar, de imediato, em condições de tomar as disposições próprias para assegurar a proteção de todos os direitos, tais como previstos no presente Ato, pode, mediante notificação depositada junto ao Diretor-Geral, no momento do depósito de seu instrumento de ratificação ou adesão ou, sem prejuízo do disposto no artigo V.1) c), em qualquer data ulterior, declarar que invocará o benefício da faculdade prevista pelo artigo II ou daquela prevista pelo artigo III ou de ambas as faculdades. Pode, em lugar de invocar o beneficio da faculdade prevista pelo artigo II, fazer uma declaração conforme o artigo V.1) a).

2) a) Qualquer declaração feita por força do parágrafo 1) e notificada antes de ter expirado um período de dez anos, contados da entrada em vigor dos artigos 1 a 21 e do presente Anexo de acordo com o artigo 28.2, permanecerá válida até que tenha expirado o referido período. Poderá ser renovada na sua totalidade ou parcialmente por outros períodos sucessivos de dez anos mediante notificação depositada junto ao Diretor-Geral, não mais de quinze meses mas não menos de três meses antes de ter expirado o período decenal em curso.

b) Qualquer declaração feita nos termos do parágrafo 1) e notificada depois de ter expirado um período de dez anos, contados da entrada em vigor dos artigos 1 a 21 e do presente Anexo de acordo com o artigo 28.2), permanece válida até que tenha expirado o período decenal em curso. Pode ser renovada como previsto na segunda frase da alínea a). 
3) Qualquer país da União que tenha deixado de ser considerado como um país em vias de desenvolvimento de acordo com o disposto na alínea 1) não estará mais habilitado a renovar sua declaração tal qual está prevista na alínea 2) e, quer retire ou não oficialmente sua declaração, tal país perderá a possibilidade de invocar o benefício das faculdades mencionadas no parágrafo 1), seja ao expirar o período decenal em curso, seja três anos depois que tenha deixado de ser considerado um país em vias de desenvolvimento, devendo ser aplicado o prazo que mais tarde vença.

4) Se, na época em que a declaração feita em virtude do parágrafo 1) ou do parágrafo 2) deixa de vigorar, houver em estoque exemplares produzidos sob o regime de uma licença concedida por força das disposições do presente Anexo, tais exemplares poderão continuar a ser postos em circulação até seu esgotamento.

5) Qualquer país que seja vinculado pelas disposições do presente Ato e que tenha depositado uma declaração ou uma notificação de acordo com o artigo 31.1 relativamente à aplicação do referido Ato a determinado território cuja situação pode ser considerada como análoga àquela dos países mencionados no parágrafo 1) pode, em relação a esse território, fazer a declaração mencionada no parágrafo 1) e a notificação de renovação indicada no parágrafo 2). Enquanto vigorar esta declaração ou esta notificação, as disposições do presente Anexo aplicar-se-ão ao território em relação ao qual a mesma foi feita.

6) a) O fato de que um país invoca o benefício de uma das faculdades mencionadas no parágrafo 1) não autoriza outro país a dar às obras cujo país de origem é o primeiro país em questão uma proteção inferior àquela que é obrigado a conceder de acordo com os artigos 1 a 20.

b) A faculdade de reciprocidade prevista pelo artigo 30.2) b), segunda frase, não pode, até a data em que expira o prazo aplicável de acordo com o artigo I.3), ser exercida para obras cujo país de origem é um país que fez declaração de acordo com o artigo V.1) a).

\section{ARTIGO II}

1) Todo país que tenha declarado que invocará o beneficio da faculdade prevista pelo presente artigo será habilitado, relativamente às obras publicadas sob forma impressa ou sob qualquer outra forma análoga de reprodução, a substituir o direito exclusivo de tradução previsto no artigo 8 por um regime de licenças não-exclusivas e intransferíveis, concedidas pela autoridade competente nas condições indicadas a seguir e de acordo com o artigo IV.

2) a) Sem prejuízo do disposto no parágrafo 3), quando, ao expirar um período de três anos ou um período mais longo determinado pela legislação nacional do referido país, contado da primeira publicação de uma obra, a tradução não foi publicada numa língua de uso geral nesse país, pelo titular do direito de tradução ou com sua autorização, qualquer nacional do referido país poderá obter uma licença para traduzir a obra na referida língua e publicar essa tradução sob forma impressa ou sob qualquer outra forma análoga de reprodução.

b) Uma licença também pode ser concedida em virtude do presente artigo se estiverem esgotadas todas as edições da tradução publicada na língua em apreço.

3) a) No caso de traduções numa língua que não é de uso geral num ou em vários países desenvolvidos, membros da União, um período de um ano substituirá o período de três anos mencionado no paragrafo 2) a).

b) Qualquer país mencionado no parágrafo 1) pode, com o acordo unânime dos países desenvolvidos, membros da União, nos quais a mesma língua é de uso geral, substituir, no caso de traduções para a referida língua, o período de três anos mencionados no parágrafo 2) a) por um período mais curto fixado de conformidade com o referido acordo, não podendo, todavia, tal período ser inferior a um ano. Entretanto, as disposições da frase precedente não são aplicáveis 
quando se trata de inglês, espanhol ou francês. Qualquer acordo neste sentido será notificado ao Diretor-Geral pelos Governos que o tiverem concluído.

4) a) Nenhuma licença mencionada no presente artigo poderá ser concedida antes de expirado um prazo suplementar de seis meses, no caso em que ela possa ser obtida ao expirar de um período de três anos, e de nove meses, no caso em que possa ser obtida ao expirar de um período de um ano:

i) contados da data em que o requerente cumpre as formalidades previstas pelo artigo IV.1);

ii) ou então, se a identidade ou o endereço do titular do direito de tradução não for conhecido, contados da data em que o requerente procede, como previsto no artigo IV.2), ao envio das cópias do requerimento apresentado por ele à autoridade competente a fim de obter a licença.

b) Se, no decurso de um prazo de seis ou de nove meses, uma tradução na língua para a qual o requerimento foi apresentado é publicada pelo titular do direito de tradução ou com a sua autorização nenhuma licença será concedida por força do presente artigo.

5) Qualquer licença mencionada no presente artigo somente poderá se concedida para fins escolares, universitários ou de pesquisa.

6) Se a tradução de uma obra for publicada pelo titular do direito de tradução ou com sua autorização por um preço comparável àquele em uso no país em causa para obras análogas, qualquer licença concedida por força do presente artigo cessará se tal tradução for na mesma língua e tiver, em essência, o mesmo conteúdo que a tradução publicada por força da licença. Poder-se-á continuar a distribuição de todos os exemplares já produzidos antes da expiração da licença, até o esgotamento dos mesmos.

7) Para as obras que são compostas principalmente de ilustrações, uma licença para realizar e publicar uma tradução do texto e para reproduzir e publicar uma tradução do texto e para reproduzir e publicar ilustrações somente poderá ser concedida se as condições do artigo III forem igualmente preenchidas.

8) Nenhuma licença poderá ser concedida por força do presente artigo quando o autor tiver retirado da circulação todos os exemplares de sua obra.

9) a) Uma licença para traduzir uma obra que tenha sido publicada sob forma impressa ou sob qualquer forma análoga de reprodução pode também ser concedida a qualquer órgão de radiodifusão que tenha sua sede num país mencionado no parágrafo 1), em conseqüência de um pedido feito à autoridade competente do país do referido organismo, contanto que tenham sido preenchidas todas as seguintes condições:

i) a tradução seja feita a partir de um exemplar produzido e adquirido de acordo com a legislação do referido país;

ii) a tradução seja utilizável somente em emissões destinadas ao ensino ou à difusão de informações de caráter cientifico ou técnico destinadas aos peritos de determinada profissão;

iii) a tradução seja utilizada exclusivamente para os fins enumerados no ponto ii) em emissões feitas licitamente e destinadas aos beneficiários no território do referido país, inclusive as emissões feitas mediante registros sonoros e visuais realizados licitamente e exclusivamente para tais emissões;

iv) os usos feitos da tradução não tenham caráter lucrativo.

b) Registros sonoros ou visuais de uma tradução feita por um órgão de radiodifusão sob o regime de uma licença concedida por força da presente alínea podem, para os fins e sem prejuízo das condições enumeradas na alínea a) e com o acordo desse órgão, ser também utilizados por qualquer 
outro órgão de radiodifusão com sede no país cuja autoridade competente concedeu a licença em questão.

c) Sempre que todos os critérios e condições enumerados na alínea a) sejam respeitados, uma licença pode igualmente ser concedida a um órgão de radiodifusão para traduzir qualquer texto incorporado numa fixação audiovisual feita e publicada unicamente para uso escolar e universitário.

d) Sem prejuízo das alíneas $a$ e $c$, as disposições dos parágrafos precedentes são aplicáveis à concessão e ao exercício de qualquer licença concedida por força do presente parágrafo.

\section{ARTIGO III}

1) Qualquer país que tenha declarado que invocará o benefício da faculdade prevista pelo presente artigo terá direito para substituir o direito exclusivo de reprodução previsto no artigo 9 por um regime de licenças não exclusivas e intrasferíveis, concedidas pela autoridade competente nas condições indicadas a seguir e de acordo com o artigo IV.

2) a) Com relação a uma obra à qual o presente artigo é aplicável por força do parágrafo 7 e quando, ao expirar:

i) do período fixado no parágrafo 3) é contado a partir da primeira publicação de uma edição determinada de uma tal obra ou

ii) de um período mais longo fixado pela legislação nacional do país mencionado no parágrafo 1) e contado a partir da mesma data,

exemplares dessa edição não foram postos à venda, no referido país, para atender às necessidades, quer do público, quer do ensino escolar e universitário, pelo titular do direito de reprodução ou com a sua autorização, por um preço comparável ao em uso em tal país para obras análogas, qualquer nacional do referido país poderá obter uma licença para reproduzir e publicar essa edição, por esse preço ou por preço inferior, a fim de atender às necessidades do ensino escolar e universitário.

b) Uma licença para reproduzir e publicar uma edição que foi posta em circulação como o descreve a alínea a) pode também ser concedida por força das condições previstas pelo presente artigo se, depois de expirado o período aplicável, exemplares autorizados dessa edição não estão mais à venda no país em questão, durante um período de seis meses, para responder às necessidades, quer do público, quer do ensino escolar e universitário, a um preço comparável àquele que é pedido no referido país para obras análogas.

3) O período a que se refere o parágrafo 2) a)i) é de cinco anos. Entretanto,

i) para as obras que tratem de ciências exatas e naturais e da tecnologia, será de três anos;

ii) para as obras que pertencem ao campo da imaginação, como romances, obras poéticas, dramáticas e musicais e para os livros de arte, será de sete anos.

4) a) No caso em que possa ser obtido após um período de três anos, a licença não poderá ser concedida por força do presente artigo antes da estipulação de um prazo de seis meses

i) a contar da data em que o requerente cumpre as formalidades previstas pelos artigo IV.1);

ii) ou então, se a identidade ou o endereço do titular do direito de reprodução não for conhecido, a contar da data em que o requerente procede, como previsto no artigo IV.2, ao envio das cópias do requerimento apresentado por ele à autoridade competente a fim de obter a licença.

b) Nos outros casos, e se o artigo IV.2) é aplicável, a licença não poderá ser concedida antes de expirado um prazo de três meses contados do envio das cópias do requerimento. 
c) Se durante o prazo de seis ou de três meses mencionado nas alíneas a) e b) houve uma distribuição, como descrito no parágrafo 2)a), nenhuma licença poderá ser concedida por força do presente artigo.

d) Nenhuma licença poderá ser concedida quando o autor tiver retirado da circulação todos os exemplares da edição para cuja reprodução e publicação a licença foi requerida.

5) Uma licença para reproduzir e publicar uma tradução de uma obra não será concedida, por força do presente artigo, nos casos abaixo:

i) quando a tradução em causa não foi publicada pelo titular do direito da tradução ou com sua autorização;

ii) quando a tradução não é feita numa língua de uso geral no país onde a licença é requerida.

6) Caso sejam postos à venda exemplares de uma edição de uma obra no país mencionado no parágrafo 1) para responder às necessidades, quer do público, quer do ensino secundário e universitário, pelo titular do direito de reprodução ou com sua autorização, por um preço comparável àquele em uso no referido país para obras análogas qualquer licença concedida por força do presente artigo caducará se essa edição for na mesma língua e tiver essencialmente o mesmo conteúdo que a edição publicada por força da licença. Poder-se-á continuar a distribuição de todos os exemplares já produzidos antes da expiração da licença até o esgotamento dos mesmos.

7) a) Sem prejuízo da alínea b), as obras às quais o presente artigo é aplicável são apenas as obras publicadas sob forma impressa ou sob qualquer outra forma análoga de reprodução.

b) O presente artigo é igualmente aplicável à reprodução audiovisual de fixações lícitas audiovisuais que constituam ou incorporem obras protegidas, assim como à tradução do texto que as acompanha numa língua de uso geral no país em que a licença é requerida, ficando bem entendido que as fixações audiovisuais em questão foram concebidas e publicadas unicamente para fins escolares e universitários.

\section{ARTIGO IV}

1) Qualquer licença mencionada no artigo II ou no artigo III somente poderá ser concedida se o requerente, de acordo com as disposições em vigor no país em causa, provar ter pedido ao titular do direito a autorização de fazer uma tradução e de publicá-la ou de reproduzir e publicar a edição, conforme o caso, e, depois das devidas diligências de sua parte, não tiver podido encontrá-lo ou não tiver podido obter sua autorização. Ao mesmo tempo em que faz tal pedido ao titular do direito, o requerente deve informar qualquer centro nacional ou internacional de informação de que trata o parágrafo 2).

2) Se o titular do direito não tiver podido ser encontrado pelo requerente, este deve dirigir, pelo correio aéreo, em carta registrada, cópias do requerimento, apresentado por ele à autoridade competente com a finalidade de obter a licença, ao editor cujo nome figura na obra e a qualquer centro nacional ou internacional de informação que possa ter sido designado, numa notificação depositada para este fim junto ao Diretor-Geral pelo Governo do país em que se presuma que o editor tenha seu lugar principal de atividades.

3) O nome do autor deve ser indicado em todos os exemplares da tradução ou da reprodução publicada sob o regime de uma licença concedida por força do artigo II ou do artigo III. O título da obra deve figurar em todos os exemplares. Se se tratar de uma tradução, o título original da obra deve em qualquer caso figurar em todos os exemplares. 
4) a) Qualquer licença concedida por força do artigo II ou do artigo III não se estenderá à exportação de exemplares e só será válida para a publicação da tradução ou da reprodução, conforme o caso, no interior do território do país em que a licença é requerida.

b) Para os fins da aplicação da alínea a), deve ser considerado como exportação, o envio de exemplares a partir de um território para um país que, para esse território, fez uma declaração de acordo com o artigo I.5).

c) Quando um órgão governamental ou qualquer outro órgão público de um país que concedeu, de acordo com o artigo II, uma licença para fazer uma tradução numa língua que não seja o inglês, o espanhol ou o francês, envia exemplares da tradução publicada por força de tal licença a um outro país, tal expedição não será considerada, para os fins da alínea a), como sendo uma exportação se todas as condições seguintes forem preenchidas:

i) os destinatários são particulares nacionais do país cuja autoridade competente concedeu à licença, ou organizações que agrupem tais nacionais;

ii) os exemplares são utilizados exclusivamente para fins escolares, universitários ou de pesquisa;

iii) o envio de exemplares e sua distribuição ulterior aos destinatários não se revestem de qualquer caráter lucrativo; e

iv) o país para o qual os exemplares foram enviados concluiu um acordo com o país cuja autoridade competente outorgou a licença para autorizar a recepção dos mesmos, ou a distribuição, ou estas duas operações, e o Governo deste último país notificou no Diretor-Geral tal acordo.

5) Todo exemplar publicado sob o regime de uma licença concedida por força do artigo II ou do artigo III deve conter menção na língua apropriada indicando que o exemplar é posto em circulação somente no país ou no território a que se aplica a referida licença.

6) a) Medidas adequadas serão tomadas no plano nacional para que:

i) a licença preveja em favor do titular do direito de tradução ou de reprodução, conforme o caso, uma remuneração equitativa e de acordo com a tabela dos pagamentos normalmente efetuadas no caso de licenças livremente negociadas entre os interessados nos dois países em causa; e

ii) sejam assegurados o pagamento e a remessa desta remuneração; se existir uma regulamentação nacional relativa a divisas, a autoridade competente não poupará esforços, recorrendo aos mecanismos internacionais, para assegurar a remessa da remuneração em moeda internacionalmente conversível ou em seu equivalente.

b) Medidas adequadas serão tomadas no âmbito da legislação nacional para que seja garantida uma tradução correta da obra ou uma reprodução exata da edição em causa, conforme o caso.

\section{ARTIGO V}

1) a) Qualquer país habilitado a declarar que invocará o benefício da faculdade prevista no artigo II pode, ao ratificar o presente Ato, ou a ele aderir, substituir tal declaração por:

i) se for um país ao qual o artigo 30.2)a) é aplicável, uma declaração nos termos desta disposição no que diz respeito ao direito de tradução;

ii) se for um país ao qual o artigo 30.2) a) não for aplicável, e mesmo se não for um país estranho à União, uma declaração como previsto pelo artigo 30.2) b), primeira frase.

b) No caso de um país que deixou de ser considerado como país em vias de desenvolvimento tal como mencionado no artigo I.1), uma declaração feita em conformidade com o presente parágrafo permanece válida até a data na qual expira o prazo aplicável de acordo com o artigo I.3).

c) Nenhum país que faça uma declaração em conformidade com o presente parágrafo poderá invocar ulteriormente o beneficio da faculdade prevista pelo artigo II, mesmo se retirar tal declaração. 
2) Sem prejuízo do parágrafo 8, nenhum país que tiver invocado o beneficio da faculdade prevista no artigo II, poderá posteriormente fazer uma declaração conforme o parágrafo 1.

3) Qualquer país que tenha deixado de ser considerado como país em vias de desenvolvimento tal como mencionado no artigo I.1) poderá, o mais tardar dois anos antes de expirar o prazo aplicável de conformidade om o artigo I.3), fazer uma declaração no sentido do artigo 30.2) b), primeira frase, não obstante o fato de não se tratar de um país estranho à União. Esta declaração entrará em vigor na data na qual expirar o prazo aplicável de acordo com o artigo I.3).

\section{ARTIGO VI}

1) Qualquer país da União pode declarar, a partir da data do presente Ato e a qualquer momento antes de tornar-se vinculado pelos artigos 1 a 21 e pelo presente Anexo:

i) se se tratar de um país que, se fosse vinculado pelos artigos 1 a 21 e pelo presente Anexo, estaria habilitado a invocar o beneficio das faculdades mencionadas no artigo I.1), que aplicará as disposições do artigo II ou do artigo III, ou de ambos, às obras cujo país de origem é um país que, em aplicação do item ii) abaixo, aceita a aplicação destes artigos para tais obras, ou que é vinculado pelos artigos 1 a 21 e pelo presente Anexo; tal declaração pode se referir ao artigo $\mathrm{V}$ em lugar do artigo II;

ii) que aceita a aplicação do presente Anexo às obras das quais é ele o país de origem pelos países que fizeram uma declaração por força do item i) acima ou uma notificação por força do artigo I.

2) Qualquer declaração em conformidade com o parágrafo 1 deve ser feita por escrito e depositada junto ao Diretor-Geral e entrará em vigor na data de seu depósito.

Em fé do que, os abaixo assinados devidamente autorizados para este fim, assinaram o presente Ato.

Feito em Paris, em 24 de julho de 1971.

Este texto não substitui o original publicado no Diário Oficial da União - Seção 1 de 09/05/1975

Publicação:

- $\quad$ Diário Oficial da União - Seção 1 - 9/5/1975, Página 5553 (Publicação Original)

- $\quad$ Coleção de Leis do Brasil - 1975, Página 148 Vol. 4 (Publicação Original) 


\section{DECRETO Nº 81.742, DE 31 DE MAIO DE 1978}

\section{Promulga o Tratado de Cooperação em Matéria de Patentes (PCT).}

O PRESIDENTE DA REPÚBLICA, CONSIDERANDO que o Congresso Nacional aprovou, pelo Decreto Legislativo $n^{\circ}$ 110, de 30 de novembro de 1977, o Tratado de Cooperação em Matéria de Patentes (PCT), concluído entre a República Federativa do Brasil e vários países na cidade de Washington em 19 de junho de 1970;

CONSIDERANDO que o Instrumento de Ratificação do referido Tratado pela República Federativa do Brasil foi depositado em 9 de janeiro de 1978; CONSIDERANDO que o referido Tratado entrou em vigor para a República Federativa do Brasil em 9 de abril de 1978;

\section{DECRETA:}

Art. $1^{\circ}$. O Tratado de Cooperação em Matéria de Patentes (PCT), apenso por cópia ao presente Decreto, será executado e cumprido tão inteiramente como nele se contém.

Art. $2^{\circ}$. Este Decreto entra em vigor na data de sua publicação, revogadas as disposições em contrário.

Brasília, em 31 de maio de 1978; $157^{\circ}$ da Independência e 90º da República.

\section{ERNESTO GEISEL}

Antônio Francisco Azeredo da Silveira

Os Estados contratantes,

Desejosos de contribuir para o desenvolvimento da ciência e da tecnologia,

Desejosos de aperfeiçoar a proteção legal das invenções,

Desejosos de simplificar e tornar mais econômica e obtenção de proteção das invenções quando a mesma for requisitada em vários países,

Desejosos de facilitar e apressar o acesso de todos às informações técnicas contidas nos documentos que descrevem as novas invenções,

Desejosos de estimular e acelerar o progresso econômico dos países em via de desenvolvimento através da adoção de medidas destinadas a aumentar a eficácia de seus sistemas legais de proteção das invenções, sejam eles nacionais ou regionais, proporcionando-lhes fácil acesso às informações referentes às obtenção de soluções técnicas adaptadas a seus requisitos específicos e facilitandolhes o acesso ao volume sempre crescente da técnica moderna,

Convencidos de que a cooperação internacional facilitará grandemente a realização destes objetivos,

Concluíram o presente Tratado:

\section{Disposições Introdutórias}

\section{Artigo 1}

Estabelecimento de uma União

1) Os Estados participantes do presente Tratado (a seguir denominados "Estados contratantes") ficam constituídos em estado de União para cooperação no terreno dos depósitos, das pesquisas e do exame dos pedidos de proteção das invenções, bem como para prestação de serviços técnicos especiais. Esta União fica denominada União Internacional de Cooperação em Matéria de Patentes. 
2) Nenhuma disposição do presente Tratado poderá ser interpretada como restrição dos direitos previstos pela Convenção de Paris para Proteção da Propriedade Industrial em benefício dos nacionais dos países participantes desta Convenção ou das pessoas domiciliadas nesses países.

\section{Artigo 2}

\section{Definições}

No sentido do presente Tratado e do Regulamento de execução, e a menos que um sentido diferente seja expressamente indicado:

I) entende-se por "pedido" um pedido de proteção de uma invenção; toda e qualquer referência a um "pedido" entender-se-á como uma referência aos pedidos de patentes de invenção, de certificados de autor de invenção, de certificados de utilidade, de modelos de utilidade, de patentes ou de certificados de adição, de certificados de autor de invenção adicionais e de certificados de utilidade adicionais;

II) toda e qualquer referência a uma "patente" entender-se-á como uma referência às patentes de invenção, aos certificados de autor de invenção, aos certificados de utilidade, aos modelos de utilidade, às patentes ou certificados de adição, aos certificados de autor de invenção adicionais e aos certificados de utilidade adicionais;

III) entende-se por "patente nacional" uma patente concedida por uma administração nacional;

IV) entende-se por "patente regional" uma patente concedida por uma administração nacional ou intergovernamental, credenciada a conceder patentes com validade em mais de um Estado;

V) entende-se por "pedido regional" um pedido de patente regional;

VI) toda e qualquer referência a um "pedido nacional" entender-se-á como uma referência aos pedidos de patentes nacionais e de patentes regionais além dos pedidos depositados em obediência ao presente Tratado;

VII) entende-se por "pedido internacional" um pedido depositado em obediência ao presente Tratado;

VIII) toda e qualquer referência a um "pedido" entender-se-á como uma referência aos pedidos internacionais e nacionais;

IX) toda e qualquer referência a uma "patente" entender-se-á como uma referência às patentes nacionais e regionais;

X) toda e qualquer referência à "legislação nacional" entender-se-á como uma referência à legislação de um Estado contratante ou, sempre que se tratar de um pedido regional ou de uma patente regional, ao tratado que prevê o depósito de pedidos regionais ou a concessão de patentes regionais;

XI) entende-se por "data de prioridade", para fins do cálculo dos prazos:

a) sempre que o pedido internacional comportar uma reivindicação de prioridade, de acordo com o artigo 8, a data do depósito do pedido cuja prioridade for assim reivindicada;

b) sempre que o pedido internacional comportar várias reivindicações de prioridade, de acordo com o artigo 8, a data do depósito do pedido mais antigo cuja prioridade for assim reivindicada;

c) sempre que o pedido internacional não comportar qualquer reivindicação de prioridade, de acordo com o artigo 8, a data do depósito internacional desse pedido;

XII) entender-se por "Repartição nacional" a administração governamental de um Estado contratante encarregada de conceder patentes; toda e qualquer referência a uma "Repartição nacional" entender-se-á igualmente como uma referência a toda e qualquer administração intergovernamental encarregada por vários Estados de conceder patentes regionais, desde que pelo 
menos um desses Estados seja um Estado contratante e que esses Estados tenham autorizado a dita administração a assumir as obrigações e a exercer os poderes que o presente Tratado e o Regulamento de execução atribuem às Repartições nacionais;

XIII) entende-se por "Repartição designada" a repartição nacional do Estado designada pelo depositante de acordo com o Capítulo I do presente Tratado, assim como toda e qualquer Repartição agindo em nome desse Estado;

XIV) entende-se por "Repartição eleita" a Repartição nacional do Estado eleita pelo depositante de acordo com o Capítulo II do presente Tratado, bem como toda e qualquer Repartição agindo em nome desse Estado;

XV) entende-se por "Repartição receptora" a Repartição nacional ou organização intergovernamental em que o pedido internacional foi depositado;

XVI) entende-se por "União" a União Internacional de Cooperação em Matéria de Patentes;

XVII) entende-se por "Assembléia" a Assembléia da União;

XVIII) entende-se por "Organização" a Organização Mundial da Propriedade Intelectual;

XIX) entende-se por "Escritório Internacional" o Escritório Internacional da Organização e, enquanto existirem, os Escritórios Internacionais Reunidos para Proteção da Propriedade Intelectual (BIRPI);

XX) entende-se por "Diretor Geral" o Diretor-Geral da Organização e, enquanto existirem os BIRPI, o Diretor dos BIRPI.

\section{CAPÍTULO I}

Pedido Internacional e Pesquisa Internacional

\section{Artigo 3}

Pedido Internacional

1) Os pedidos de proteção das invenções em todo e qualquer Estado contratante podem ser depositados na qualidade de pedidos internacionais no sentido do presente Tratado.

2) Um pedido internacional deverá conter, de acordo com o presente Tratado e com o Regulamento de execução, um requerimento, uma descrição, uma ou várias reivindicações, um ou vários desenhos (quando estes forem necessários) e um resumo.

3) O resumo destina-se exclusivamente para fins de informação técnica; não poderá ser levado em consideração para qualquer outro fim, mormente para avaliação da extensão da proteção pedida.

4) O pedido internacional:

I) deve ser redigido em uma das línguas prescritas;

II) deve preencher as condições materiais prescritas;

III) deve satisfazer a exigência prescrita de unidade de invenção;

IV) está sujeito ao pagamento das taxas prescritas.

\section{Artigo 4}

Requerimento

1) O requerimento deve conter: 
I) uma petição no sentido de que o pedido internacional deverá ser considerado de acordo com o presente Tratado;

II) a designação do Estado ou Estados contratantes em que a proteção da invenção é solicitada na base do pedido internacional ("Estados designados"); se o depositante puder e desejar, em relação a todo e qualquer Estado designado, obter uma patente regional em lugar de uma patente nacional, o requerimento deverá indicá-lo; se o depositante, em virtude de um tratado referente a uma patente regional, não puder limitar seu pedido a certos Estados participantes do tratado em questão, a designação de um desses Estados, bem como a indicação de desejo de obter uma patente regional serão assimilados a uma designação de todos esses Estados; se, de acordo com a legislação nacional do Estado designado, a designação desse Estado tiver o efeito de um pedido regional, essa obrigação deverá ser assimilada à indicação do desejo de obter uma patente regional;

III) o nome e outras indicações prescritas, referentes ao depositante e ao mandatário (caso haja);

IV) o título da invenção;

V) o nome do inventor e demais indicações prescritas, no caso em que a legislação de pelo menos um dos Estados designados exija que essas indicações seja fornecidas a partir do depósito de um pedido nacional; nos demais casos as ditas indicações podem figurar que no requerimento, quer em notificações separadas endereçadas a cada Repartição designada cuja legislação nacional exija essas indicações, permitindo, entretanto, que elas só sejam fornecidas depois do depósito do pedido nacional.

2) Toda e qualquer designação está sujeita ao pagamento das taxas prescritas dentro do prazo prescrito.

3) Se o depositante não solicitar outros títulos de proteção referidos no artigo 43, a designação significará que a proteção pedida consiste na concessão de uma patente pelo ou para o Estado designado. O artigo 2.II) não se aplica aos fins do presente parágrafo.

4) A ausência, no requerimento, do nome do inventor e das demais indicações prescritas referentes ao inventor não provoca qualquer conseqüência nos Estados designados cuja legislação exija essas indicações, permite, porém, que elas não sejam apresentadas senão depois de efetuado o depósito do pedido nacional. A ausência dessas indicações em uma notificação separada não provoca qualquer conseqüência nos Estados designados em que essas indicações não sejam exigidas pela legislação nacional.

\section{Artigo 5}

Descrição

A descrição deve fazer uma exposição da invenção suficientemente clara e completa para que um profissional do ramo possa executá-la.

\section{Artigo 6}

\section{Reivindicações}

A ou as reivindicações devem definir a finalidade da proteção solicitada. As reivindicações deverão ser claras e concisas. Devem basear-se totalmente na descrição.

\section{Artigo 7}

Desenhos

1) Com ressalva do parágrafo 2)II), deverão ser fornecidos desenhos sempre que forem necessários à compreensão da invenção.

2) Se a invenção for de natureza tal que possa ser ilustrada por desenhos, mesmo que estes não sejam indispensável à sua compreensão; 
I) o depositante poderá incluir tais desenhos no pedido internacional na ocasião de seu depósito;

II) toda e qualquer Repartição designada poderá exigir que o depositante lhe forneça tais desenhos no prazo determinado.

\section{Artigo 8}

Reivindicações de prioridade

1) O pedido internacional pode comportar uma declaração, em obediência às estipulações do Regulamento de execução, reivindicando a prioridade de um ou de vários pedidos anteriores depositados em ou por todo e qualquer país participante da Convenção de Paris para Proteção da Propriedade Industrial.

2)a) Com ressalva da alínea b), as condições e os efeitos de toda e qualquer reivindicação de prioridade apresentada em obediência ao parágrafo 1) são aqueles previstos pelo artigo 4 do Ato de Estocolmo da Convenção de Paris para Proteção da Propriedade Industrial.

b) O pedido internacional que reivindicar a prioridade de um ou vários pedidos anteriores depositados em ou por um Estado contratante pode designar esse Estado. Se o pedido internacional reivindicar a prioridade de um ou de vários pedidos nacionais depositados em ou por um Estado designado, ou a prioridade de um pedido internacional que designara um único Estado, as condições e os efeitos produzidos pela reivindicação de prioridade nesse Estado são aqueles previstos pela legislação nacional deste último.

\section{Artigo 9}

Depositante

1) Toda e qualquer pessoa domiciliada em um Estado contratante e todo e qualquer nacional de um tal Estado podem depositar um pedido internacional.

2) A Assembléia pode resolver permitir às pessoas domiciliadas em todo e qualquer país participante da Convenção de Paris para Proteção da Propriedade Industrial que não for participante do presente Tratado, bem como aos nacionais desse país, que depositem pedidos internacionais.

3) As noções de domicílio e de nacionalidade, bem como a aplicação dessas noções quando existirem vários depositantes ou quando os depositantes não sejam os mesmos para todos os Estados designados, são definidas no Regulamento de execução.

\section{Artigo 10}

Repartição receptora

O pedido internacional dever ser depositado na Repartição receptora prescrita, que o controla e processa de acordo com o presente Tratado e com o regulamento de execução.

\section{Artigo 11}

Data do depósito e efeitos do pedido internacional

1) A Repartição receptora, no que respeita a data do depósito internacional, consigna a data de recebimento do pedido internacional, desde que constate, na ocasião desse recebimento, que:

I) o depositante não esteja privado, claramente, por motivos de domicílio ou de nacionalidade, do direito de depositar um pedido internacional na Repartição receptora;

II) o pedido internacional está redigido na língua prescrita;

III) o pedido internacional comporte pelo menos os seguintes elementos:

a) uma indicação de que foi depositado o título de pedido internacional; 
b) a designação de pelo menos um Estado contratante;

c) o nome do depositante, indicado da forma prescrita;

d) uma parte que, à primeira vista, pareça constituir uma descrição;

e) uma parte que, à primeira vista, pareça constituir uma ou mais reivindicações.

2)a) Se a Repartição receptora constatar que o pedido internacional não preenche, na ocasião do seu recebimento, as condições enumeradas do parágrafo 1), solicitará ao depositante, de acordo com o Regulamento de execução, que faça a necessária correção.

b) Se o depositante cumprir a solicitação, de acordo com o Regulamento de execução, a Repartição receptora consignará, no que diz respeito à data do depósito internacional, a data do recebimento da correção exigida.

3) Com ressalva do artigo 64.4), qualquer pedido internacional que preencha as condições enumeradas nos pontos I) a III) do parágrafo 1) e ao qual foi consignada uma data de depósito internacional terá os efeitos, a partir da data do depósito internacional, de um depósito nacional regular em cada um dos Estados designados; essa data será considerada como data do depósito efetivo em cada um dos Estados designados.

4) Todo e qualquer pedido internacional que preencha as condições enumeradas nos pontos I) a III) do parágrafo 1) é considerado como possuindo o valor de um depósito nacional regular no sentido da Convenção de Paris para Proteção da Propriedade Industrial.

\section{Artigo 12}

Transmissão do pedido internacional ao Escritório internacional

e à Administração encarregada da pesquisa internacional

1) Uma via do pedido internacional fica em poder da Repartição receptora ("cópia para a Repartição receptora"), uma via ("via original") é transmitida ao Escritório Internacional e uma outra via ("cópia de pesquisa") é transmitida à Administração competente encarregada da pesquisa internacional estipulada pelo artigo 16, de acordo com o Regulamento de execução.

2) A via original é considerada como a via autêntica do pedido internacional.

3) O pedido internacional é considerado como retirado se o Escritório Internacional não receber a via original no prazo prescrito.

\section{Artigo 13}

Possibilidade de as Repartições designadas receberem cópia do pedido internacional

1) Toda e qualquer Repartição designada pode solicitar ao Escritório Internacional uma cópia do pedido internacional antes da comunicação prevista no artigo 20; o Escritório Internacional remeter-lhe-á tal cópia tão cedo quanto possível após a expiração do prazo de um ano a contar da data de prioridade.

2)a) O depositante pode, a qualquer época, remeter a toda e qualquer repartição designada uma cópia do seu pedido internacional.

b) O depositante pode, a qualquer época, solicitar ao Escritório Internacional que remeta a toda e qualquer Repartição designada uma cópia de seu pedido internacional; o Escritório Internacional remeterá, tão cedo quanto possível, essa cópia à Repartição em questão.

c) Toda e qualquer Repartição nacional pode notificar o Escritório Internacional de que não deseja receber as cópias referidas pela alínea $b$ ); nesse caso, a citada alínea não se aplicará a essa Repartição. 


\section{Artigo 14}

Irregularidades no pedido internacional

1)a) A Repartição receptora verificará se o pedido internacional apresenta quaisquer das seguintes irregularidades:

I) não está assinado de acordo com o regulamento de execução;

II) não contém as indicações estabelecidas em relação ao depositante;

III) não contém um título;

IV) não contém um resumo;

V) não preenche, da forma prevista pelo regulamento de execução, as condições materiais prescritas.

b) Se a Repartição receptora constatar qualquer uma dessas irregularidades, solicitará ao depositante que corrija o pedido internacional no prazo presrito; caso não o faça, esse pedido será considerado como retirado e a Repartição receptora assim o declarará.

2) Se o pedido internacional se referir a desenhos, embora estes não hajam sido incluídos no pedido, a Repartição receptora notificará ao depositante que poderá remeter os desenhos no prazo prescrito; a data do depósito internacional será então a data do recebimento dos referidos desenhos pela Repartição receptora. De outro modo, qualquer referência e tais desenhos será considerada como inexistente.

3)a) Se a Repartição receptora constatar que as taxas prescritas pelo artigo 3.4(IV) não foram pagas no prazo prescrito, ou que a taxa prescrita pelo artigo 4.2) não foi paga em relação a nenhum dos Estados designados, o pedido internacional será considerado como retirado e a Repartição receptora assim o declarará.

b) Se a Repartição receptora constatar que a taxa prescrita pelo artigo 4.2) foi paga dentro do prazo prescrito em ralação a um ou vários Estados designados (mas não em relação a todos esses Estados), a designação desses Estados para os quais a taxa não foi paga dentro do prazo prescrito será considerada como retirada e a Repartição receptora assim o declarará.

4) Se, depois que houver consignado ao pedido internacional uma data de depósito internacional, a Repartição receptora constatar, dentro do prazo prescrito, que qualquer uma das condições enumeradas nos pontos I) a III) do artigo 11.1) não foi preenchida nessa data, esse pedido será considerado como retirado e a Repartição receptora assim o declarará.

\section{Artigo 15}

Pesquisa internacional

1) Cada pedido internacional constituirá objeto de uma pesquisa internacional.

2) A pesquisa internacional tem por objetivo descobrir o estado da técnica pertinente.

3) A pesquisa internacional será efetuada na base das reivindicações, levando em conta a descrição e os desenhos (caso os haja).

4) A Administração encarregada da pesquisa internacional a que se refere o artigo 16, ser esforçará por descobrir o estado da técnica pertinente na medida em que lhe permitirem os seus meios e deverá, em todo caso, consultar a documentação especificada pelo Regulamento de execução.

5)a) O titular de um pedido internacional depositado na Repartição nacional de um Estado contratante ou na Repartição agindo em nome de um tal Estado poderá, se a legislação nacional desse Estado assim o permitir e nas condições previstas por essa legislação, solicitar que uma pesquisa semelhante a uma pesquisa internacional ("pesquisa do tipo internacional") seja efetuada em relação a esse pedido. 
b) A Repartição nacional de um Estado contratante ou a Repartição agindo em nome de um tal Estado, poderá, se a legislação nacional desse Estado assim o permitir, submeter a uma pesquisa do tipo internacional qualquer pedido nacional ali depositado.

c) A pesquisa do tipo internacional será efetuada pela Administração encarregada da pesquisa internacional a que se refere o artigo 16, que seria competente para proceder à pesquisa internacional se o pedido nacional fosse um pedido internacional depositado na Repartição mencionada nas alíneas $a$ ) e $b$ ). Se o pedido nacional estiver redigido em uma língua que a Administração encarregada da pesquisa internacional julgar não estar em condições adequadas de processar, a pesquisa do tipo internacional será efetuada na base de uma tradução preparada pelo depositante em uma das línguas precritas para os pedidos internacionais que a dita Administração se comprometer a aceitar para os pedidos internacionais. O pedido nacional e a tradução, quanto esta for exigida, devem ser apresentadas na forma prescrita para os pedidos internacionais.

\section{Artigo 16}

Administração encarregada da pesquisa internacional

1) A pesquisa internacional será efetuada por uma Administração encarregada da pesquisa internacional; esta poderá ser, quer uma Repartição nacional, quer uma organização intergovernamental, como o Instituto Internacional de Patentes, cujas atribuições incluem o estabelecimento de intercâmbio de pesquisa documentária sobre o estado da técnica relativa a invenções que constituam objeto de pedidos de patentes.

2) Se, enquanto não for instituída uma única Administração encarregada da pesquisa internacional, existirem várias Administrações incumbidas da pesquisa internacional, cada Repartição receptora deverá especificar, de acordo com as disposições do acordo aplicável mencionado no parágrafo 3)b), aquela ou aquelas Administrações que terão competência para proceder à pesquisa para os pedidos internacionais depositados naquela Repartição.

3)a) As Administrações encarregadas da pesquisa internacional são nomeadas pela Assembléia. Todas as Repartições nacionais e todas as organizações intergovernamentais que satisfizerem as exigências estipuladas na alínea $c$ ) poderão ser nomeadas em caráter de Administração encarregada da pesquisa internacional.

b) A nomeação dependerá do consentimento da Repartição nacional ou da organização intergovernamental em questão e da conclusão de um acordo, que deverá ser aprovado pela Assembléia, entre essa Repartição ou essa organização e o Escritório Internacional. Tal acordo especificará os direitos e obrigações das partes e conterá, especificamente, o compromisso formal da citada Repartição ou da citada organização de aplicar e cumprir as regras comuns da pesquisa internacional.

c) O Regulamento de execução estabelece as exigências mínimas, em particular aquelas concernentes ao pessoal e à documentação, que cada Repartição ou organização deverá satisfazer antes de poder ser nomeada e que deverá continuar a satisfazer enquanto perdurar a nomeação.

d) A nomeação é feita por um período determinado que poderá ser prolongado.

e) Antes de tomar uma decisão quanto à nomeação de uma Repartição nacional ou de uma organização intergovernamental ou quanto à prolongação de uma tal nomeação, assim como antes de permitir que uma tal nomeação chegue ao fim, a Assembléia consultará a Repartição ou a organização em questão e ouvirá o parecer do Comitê de Cooperação Técnica a que se refere o artigo 56, uma vez instituído esse Comitê. 


\section{Artigo 17}

Procedimento junto à Administração encarregada da pesquisa internacional

1) O procedimento junto à Administração encarregada da pesquisa internacional é determinado pelo presente Tratado, pelo Regulamento de execução e pelo acordo que o Escritório Internacional concluir, em obediência ao presente Tratado, com essa Administração.

2)a) Se a Administração encarregada da pesquisa internacional julgar:

I) que o pedido internacional ser refere a um objeto a respeito do qual não lhe compete, de acordo com o Regulamento, realizar a pesquisa e decide no caso não proceder à pesquisa, ou

II) que a descrição, as reivindicações ou os desenhos não preenchem os requisitos prescritos de modo a não permitir que uma pesquisa satisfatória seja realizada, ela o declarará e comunicará ao depositante e ao Escritório Internacional que não haverá relatório de pesquisa internacional.

b) Se qualquer das hipóteses mencionadas na alínea $a$ ) não ocorrer senão em relação a certas reivindicações o relatório de pesquisa internacional será estabelecido para as demais reivindicações, mencionando o impedimento em relação às primeiras, de acordo com o artigo 18.

3)a) Se a Administração encarregada da pesquisa internacional julgar que o pedido internacional não satisfaz a exigência de uma unidade de invenção, ela solicitará ao depositante que pague as taxas adicionais. A Administração encarregada da pesquisa internacional estabelecerá o relatório de pesquisa internacional em relação às partes do pedido internacional que dizem respeito à invenção mencionada primeiramente nas reivindicações ("invenção principal") e, se as taxas adicionais requeridas houverem sido pagas dentro do prazo prescrito, quanto às partes do pedido internacional que dizem respeito às invenções em relação às quais as citadas taxas foram pagas.

b) A legislação nacional de todo e qualquer Estado designado poderá prever que, caso a Repartição nacional desse Estado julgue justificada a solicitação, mencionada na alínea $a$ ), da Administração encarregada da pesquisa e caso o depositante não haja pago todas as taxas adicionais, as partes do pedido internacional que, consequentemente, não constituirem objeto de uma pesquisa serão consideradas como retiradas no que diz respeito aos efeitos nesse Estado, a menos que o depositante pague uma taxa especial à Repartição nacional do Estado em questão.

\section{Artigo 18}

Relatório de pesquisa internacional

1) O relatório de pesquisa internacional será estabelecido dentro do prazo e na forma prescritos.

2) O relatório de pesquisa internaiconal, tão logo seja estabelecido, será comunicado pela Administração encarregada da pesquisa internacional ao depositante e ao Escritório Internacional.

3) O relatório de pesquisa internacional ou a declaração mencionada no artigo 17.2)a) será traduzido de acordo com o Regulamento de execução. As traduções serão preparadas pelo Escritório Internacional ou sob sua responsabilidade.

\section{Artigo 19}

\section{Modificação das reivindicações submetidas ao Escritório Internacional}

1) Após receber comunicação do relatório de pesquisa internacional, o depositante terá o direito de modificar uma vez as reivindicações do pedido internacional, depositando as modificações, dentro do prazo prescrito, no Escritório Internacional. Poderá juntar as mesmas uma breve declaração, de acordo com o Regulamento de execução, explicando as modificações e esclarecendo os efeitos que estas poderão ter sobre a descrição e dos desenhos.

2) As modificações não devem ir além da exposição da invenção constante do pedido internacional tal como foi depositado. 
3) A inobservância das disposições do parágrafo 2) não terá conseqüências nos Estados designados cuja legislação nacional permita que as modificações vão além da exposição da invenção.

\section{Artigo 20}

Comunicação às Repartições designadas

1)a) O pedido internacional, juntamente com o relatório de pesquisa internacional (inclusive qualquer indicação mencionada no artigo 17.2)b) ou a declaração mencionada no artigo 17.2)a), será comunicado, de acordo com o Regulamento de execução a todas as Repartições designadas que não hajam renunciado, total ou parcialmente, a essa comunicação.

b) A comunicação compreende a tradução (tal como foi estabelecida) do relatório em questão ou da declaração citada.

2) Caso as reinvindicações hajam sido modificadas de acordo com o artigo 19.1), a comunicação deverá incluir quer o texto integral das reinvindicações tal como foram depositadas e tal como foram modificadas, quer o texto integral das reinvindicações tal como foram depositadas e especificar as modificações efetuadas; deverá, outrossim, se for o caso, incluir a declaração mencionada no artigo 19.1).

3) A pedido da Repartição designada ou do depositante, a Administração encarregada da pesquisa internacional lhes remeterá, de acordo com o Regulamento de execução, cópia dos documentos citados no relatório de pesquisa internacional.

\section{Artigo 21}

Publicação internacional

1) O Escritório Internacional procederá à publicação dos pedidos internacionais.

2)a) Com ressalva das exceções previstas na alínea $b$ ) e no artigo 64.3), a publicação internacional do pedido internacional será feita logo após a expiração de um prazo de dezoito meses a contar da data de prioridade desse pedido.

b) O depositante poderá solicitar ao Escritório Internacional a publicação de seu pedido internacional a qualquer época antes da expiração do prazo mencionado na alínea $a$ ). O Escritório Internacional procederá, em conseqüência, de acordo com o Regulamento de execução.

4) A língua e a forma da publicação internacional, bem como outros pormenores, serão estabelecidos pelo Regulamento de execução.

5) Não será feita qualquer publicação internacional caso o pedido internacional seja retirado ou considerado como retirado antes de terminado o preparo técnico da publicação.

6) Se o Escritório Internacional julgar que o pedido internacional contém expressões ou desenhos contrários aos bons costumes ou à ordem pública, ou declarações difamantes de acordo com o espírito do Regulamento de execução, poderá omiti-lo de suas publicações, indicando o local e o número de palavras ou de desenhos omitidos. Fornecerá, a pedido, cópias especiais das passagens assim omitidas.

\section{Artigo 22}

Cópias, traduções e taxas para as Repartições designadas

1) O depositante remeterá a cada Repartição designada uma cópia do pedido internacional (exceto se a comunicação mencionada no artigo 20 já sido feita) e uma tradução (tal como for prescrito) desse pedido e lhe pagará (se for o caso) a taxa nacional, o mais tardar na ocasião da expiração de um prazo de vinte meses a contar da data da prioridade. No caso em que o nome do inventor e demais indicações prescritas pela legislação do Estado designado, referentes ao nacional, o depositante deverá, caso já não hajam sido incluídos no requerimento, comunicá-los à Repartição 
nacional desse Estado ou à Repartição agindo em nome desta última, o mais tardar, na ocasião da expiração de um prazo de vinte meses a contar da data de prioridade.

2) Não obstante as disposições do parágrafo 1), quando a Administração encarregada da pesquisa internacional declarar, de acordo com o artigo 17.2)a), que um relatório de pesquisa internacional não será estabelecido, o prazo para efetuação dos atos mencionados no parágrafo 1) do presente artigo será de dois meses a contar da data da notificação da citada declaração ao depositante.

3) A legislação de todo e qualquer Estado contratante poderá, para fins dos atos a que se referem os parágrafos 1) e 2), estabelecer prazos que expirem depois daqueles mencionados nos ditos parágrafos.

\section{Artigo 23}

Suspensão do processo nacional

1) Nenhuma Repartição designada poderá processar ou examinar o pedido internacional antes da expiração do prazo aplicável de acordo com o artigo 22.

2) Não obstante as disposições do parágrafo 1), qualquer Repartição designada poderá, a pedido expresso do depositante, tratar ou examinar a qualquer época o pedido internacional.

\section{Artigo 24}

Possível perda dos efeitos nos Estados designados

1) Com ressalva do artigo 25 no caso mencionado no ponto II), abaixo, os efeitos do pedido internacional previstos pelo artigo 11.3) cessarão em qualquer Estado designado e esta cessação terá as mesmas conseqüências que a retirada de um pedido nacional nesse Estado:

I) se o depositante retirar seu pedido internacional ou a designação desse Estado;

II) se o pedido internacional for considerado como retirado em virtude dos artigos 12.3), 14.1)b), 14.3)a) ou 14.4), ou se a designação desse Estado for considerada como retirada de acordo com o artigo 14.3)b);

III) se o depositante não executar, no prazo aplicável, os atos mencionados no artigo 22.

2) Não obstante as disposições do parágrafo 1), qualquer Repartição designada poderá manter os efeitos previstos pelo artigo 11.3) mesmo quando não for exigido que tais efeitos sejam mantidos em virtude do artigo 25.2).

\section{Artigo 25}

Revisão pelas Repartições designadas

1)a) Quando a Repartição receptora recusar a consignação de uma data de depósito internacional ou declarar que o pedido internacional é considerado como retirado, ou quando o Escritório Internacional fizer uma constatação tal como estipulada no artigo 12.3), o Escritório Internacional remeterá, em curto prazo, a pedido do depositante, a todas as Repartições designadas indicadas por este último, cópia de todo e qualquer documento incluído no processo.

b) Quando a Repartição receptora declarar que a designação de um Estado é considerada como retirada, o Escritório Internacional, a pedido do requerente, remeterá a curto prazo à Repartição nacional desse Estado cópia de todo e qualquer documento contido no processo.

c) Os requerimentos fundados nas alíneas $a$ ) ou $b$ ) deverão ser apresentados dentro do prazo prescrito.

2)a) Com ressalva das disposições da alínea $b$ ), toda Repartição designada, caso a taxa nacional (se for o caso) haja sido paga e caso a tradução apropriada (tal como foi prescrito) haja sido remetida dentro do prazo prescrito, decidirá se a recusa, a declaração ou a constatação mencionadas no parágrafo 1) foram justificadas do ponto de vista do presente Tratado e do Regulamento de 
execução; se constatar que a recusa ou a declaração resultaram de um engano ou de uma omissão da Repartição receptora, ou que a constatação foi resultante de um engano ou de uma omissão do Escritório Internacional, processará o pedido internacional, para os fins de seus efeitos no Estado da Repartição designada, como se tal engano ou omissão não houvessem ocorrido.

b) Quando a via original chegar ao Escritório Internacional depois de expirado o prazo prescrito pelo artigo 12.3) em virtude de um engano ou de uma omissão do depositante, a alínea $a$ ) não se aplica senão nas circunstâncias mencionadas pelo artigo 48.3).

\section{Artigo 26}

Oportunidade de corrigir nas Repartições designadas

Nenhuma Repartição designada poderá rejeitar um pedido internacional sob a alegação de que este último não preenche as condições do presente Tratado e do Regulamento de execução sem primeiro dar ao depositante a oportunidade de corrigir o referido pedido na medida e segundo o procedimento estabelecidos pela legislação nacional para casos semelhantes ou comparáveis a de pedidos nacionais.

\section{Artigo 27}

Exigências nacionais

1) Nenhuma legislação nacional poderá exigir que o pedido internacional satisfaça, quanto a sua forma ou a seu conteúdo, exigências diferentes daquelas previstas por este Tratado e pelo Regulamento de execução ou a exigências suplementares.

2) As disposições do parágrafo 1) não afetam o artigo 7.2) nem impedem qualquer legislação nacional de exigir, uma vez iniciado o processo do pedido internacional dentro da Repartição designada:

I) quando o depositante for uma pessoa jurídica, a indicação do nome de um diretor desta última autorizado a representá-la;

II) a remessa de documentos que não pertençam ao pedido internacional mas que constituam prova de alegações ou de declarações contidas nesse pedido, inclusive a confirmação do pedido internacional pela assinatura do depositante quando esse pedido, tal como foi depositado, tiver a assinatura do seu representante ou de seu mandatário.

3) Quando o depositante, para os fins de qualquer Estado designado, não for qualificado, de acordo com a legislação desse Estado para fazer o depósito de um pedido nacional, em virtude de não ser o inventor, o pedido internacional poderá ser rejeitado pela Repartição designada.

4) Quando a legislação nacional dispuser no que concerne à forma e ao conteúdo dos pedidos nacionais, sobre exigências que, do ponto de vista dos depositantes, são mais favoráveis que aquelas previstas pelo presente Tratado e o Regulamento de execução para os pedidos internacionais, a Repartição nacional, os tribunais e todos os demais órgãos competentes do Estado designado ou agindo em nome deste último, poderão aplicar as primeiras exigências, em lugar das últimas, aos pedidos internacionais, exceto se o depositante requerer que as exigências previstas pelo presente Tratado e pelo Regulamento de execução sejam aplicados a seu pedido internacional.

5) Nada constante do presente Tratado e do Regulamento de execução poderá ser compreendido como podendo limitar a liberdade de qualquer Estado contratante de estabelecer todas as condições materiais para concessão de patentes que desejar. Em particular, qualquer disposição do presente Tratado e do Regulamento de execução referente à definição do estado da técnica deverá ser exclusivamente considerada para os fins do processo internacional; por conseguinte, qualquer Estado contratante poderá aplicar, ao determinar se uma invenção objeto de um pedido internacional faz ou não jus a uma patente, os critérios de sua legislação nacional relativos ao estado da técnica e de outras condições necessárias à obtenção de patentes que não constituam exigências relativas à forma e ao conteúdo dos pedidos. 
6) A legislação nacional poderá exigir do depositante que forneça provas quanto a qualquer condição de direito material à patente que ela estipule.

7) Qualquer Repartição receptora, assim como qualquer Repartição designada, que houver iniciado o processo do pedido internacional, poderá aplicar qualquer disposição de sua legislação nacional relativa à representação obrigatória do depositante por um mandatário habilitado junto a essa Repartição e à indicação obrigatória de um endereço de trabalho no Estado designado para fins de recebimento de notificações.

8) Nada constante do presente Tratado e do Regulamento de execução poderá ser interpretado como capaz de limitar a liberdade de qualquer Estado contratante de aplicar as medidas que considerar necessárias em matéria de defesa nacional ou de limitar, para defender seus interesses econômicos, o direito de seus nacionais ou das pessoas domiciliadas em seu território de depositar pedidos internacionais.

\section{Artigo 28}

Modificação das reivindicações, da descrição e dos desenhos nas Repartições designadas

1) O depositante deverá ter oportunidade de modificar as reivindicações, a descrição e os desenhos, dentro do prazo prescrito, em cada Repartição designada. Nenhuma Repartição designada poderá conceder patente ou recusar-se a concedê-la antes de expirado esse prazo, exceto com o acordo expresso do depositante.

2) As modificações não deverão ir além da exposição da invenção que consta do pedido internacional tal como foi depositado, a menos que a legislação nacional do Estado designado o faculte expressamente.

3) As modificaçõs deverão ser conformes à legislação nacional do Estado designado em relação a tudo quanto não for estabelecido pelo presente Tratado ou pelo Regulamento de execução.

4) Quando a Repartição designada exigir uma tradução do pedido internacional, as modificações deverão ser apresentadas na mesma língua da tradução.

\section{Artigo 29}

Efeitos da publicação internacional

1) No que concerne à proteção de qualquer direito do depositante em um Estado designado, a publicação internacional de um pedido internacional terá, nesse Estado, com ressalva das disposições constantes dos parágrafos 2) a 4), os mesmos efeitos que os estabelecidos pela legislação nacional desse Estado à publicação nacional obrigatória de pedidos nacionais não examinados como tais.

2) Se a língua da publicação internacional diferir daquela das publicações requeridas pela legislação nacional do Estado designado, a dita legislação nacional poderá estipular que os efeitos previsto no parágrafo 1) não se produzam senão a partir da data em que:

I) uma tradução nesta última língua seja publicada de acordo com a legislação nacional; ou

II) uma tradução nesta última língua seja posta à disposição do público para inspeção, de acordo com a legislação nacional; ou

III) uma tradução nesta última língua seja transmitida pelo depositante ao usuário não autorizado, efetivo ou eventual, da invenção que constitui objeto do pedido internacional; ou

IV) os dois atos a que se referem os pontos I) e III) ou os dois atos a que se referem os pontos II) e III) tenham sido executados.

3) A legislação nacional de qualquer Estado designado poderá estipular que, no caso da publicação internacional ser efetuada, a pedido do depositante, antes da expiração de um prazo de dezoito 
meses contados da data de prioridade, os efeitos previstos no parágrafo 1) não se produzam senão depois de expirado um prazo de dezoito meses contados da data de prioridade.

4) A legislação nacional de qualquer Estado designado poderá prever que os efeitos a que se refere o parágrafo 1) não se produzam senão a partir da data do recebimento, por sua Repartição nacional ou pela Repartição agindo em nome desse Estado, de uma via da publicação, efetuada de acordo com o artigo 21, do pedido internacional. Essa Repartição publicará, assim que possível, a data do recebimento em sua Gazeta.

\section{Artigo 30}

Caráter confidencial do pedido internacional

1)a) Ressalvada a alínea $b$ ), o Escritório Internacional e as Administrações encarregadas da pesquisa internacional não deverão permitir a nenhuma pessoa ou administração acesso ao pedido internacional antes de sua publicação internacional, a menos que seja requerido pelo depositante ou com sua autorização.

b) A alínea $a$ ) não se aplica às transmissões à Administração competente encarregada da pesquisa internacional, às transmissões previstas no artigo 13, nem às comunicações previstas no artigo 20.

2)a) Nenhuma Repartição nacional poderá permitir a terceiros acesso ao pedido internacional, exceto por requerimento ou autorização do depositante, antes de qualquer das datas seguintes que ocorra primeiro:

I) data da publicação internacional do pedido internacional;

II) data do recebimento da comunicação do pedido internacional, de acordo com o artigo 20;

III) data do recebimento de uma cópia do pedido internacional, de acordo com o artigo 22.

b) A alínea $a$ ) não impedirá uma Repartição nacional de informar a terceiros que foi designada, nem de publicar esse fato. Uma tal informação ou publicação poderá entretanto, conter apenas as seguintes indicações: identificação da Repartição receptora, nome do depositante, data do depósito internacional, número do pedido internacional e título da invenção.

c) A alínea a) não poderá impedir que uma Repartição designada permita às autoridades judiciárias acesso ao pedido internacional.

3) O parágrafo 2)a) aplica-se a qualquer Repartição receptora, exceto quanto às transmissões previstas no artigo 12.1).

4) Do ponto de vista do presente artigo, a expressão «acesso» inclui qualquer meio através do qual terceiros possam tomar conhecimento e inclui, pois, a comunicação individual e a publicação geral; entretanto, nenhuma Repartição nacional poderá publicar um pedido internacional ou sua tradução antes da publicação internacional ou antes expirado um prazo de vinte meses a contar da data de prioridade, caso a publicação internacional não ocorra quando da expiração desse prazo.

\section{Capítulo II}

Exame Preliminar Internacional

\section{Artigo 31}

Pedido de exame preliminar internacional

1) A pedido do depositante, o pedido internacional constituirá o objeto de um exame preliminar internacional de acordo com as disposições seguintes e o Regulamento de execução.

2)a) Qualquer depositante que, do ponto de vista do Regulamento de execução, esteja domiciliado em um Estado contratante obrigado pelo Capítulo II ou for um nacional de um tal Estado e cujo 
pedido internacional haja sido depositado na Repartição receptora desse Estado ou agindo em nome desse Estado, poderá apresentar um pedido de exame preliminar internacional.

b) A Assembléia poderá decidir permitir às pessoas autorizadas a depositar pedidos internacionais à apresentar pedidos de exame preliminar internacional mesmo que elas sejam domiciliadas em um Estado não-contratante ou não-obrigado pelo Capítulo II ou que possuam a nacionalidade de um tal Estado.

3) O pedido de exame preliminar internacional deverá ser feito independentemente do pedido internacional. Deverá conter as indicações prescritas e ser feito na língua e na forma prescritas.

4)a) O pedido de exame preliminar internacional deverá indicar aquele ou aqueles Estados contratantes em que o depositante pretende utilizar os resultados do exame preliminar internacional («Estados eleitos»). Estados contratantes adicionais poderão ser eleitos posteriormente. As eleições não poderão visar senão os Estados contratantes já designados de acordo com o artigo 4.

b) Os depositantes enquadrados no parágrafo 2)a) poderão eleger qualquer Estado contratante obrigado pelo Capítulo II. Os depositantes enquadrados no parágrafo 2)b) não poderão eleger senão os Estados contratantes obrigados pelo Capítulo II que se tenham declarado disposto a serem eleitos por tais depositantes.

5) O pedido de exame preliminar internacional está sujeito ao pagamento das taxas prescritas dentro do prazo prescrito.

6)a) o pedido de exame preliminar internacional deverá ser apresentado à Administração competente encarregada do exame preliminar internacional mencionada no artigo 32.

b) Qualquer eleição posterior deverá ser submetida ao Escritório Internacional.

7) Cada Repartição eleita receberá notificação de sua eleição.

\section{Artigo 32}

Administração encarregada do exame preliminar internacional

1) O exame preliminar internacional será efetuado pela Administração encarregada do exame preliminar internacional.

2) No caso dos pedidos de exame preliminar internacional a que se referem o artigo 31.2)a) e o artigo 31.2)b), a Repartição receptora ou a Assembléia, respectivamente, especificarão, de acordo com as disposições do acordo aplicável concluindo entre a Administração ou Administrações interessadas encarregadas do exame preliminar internacional e o Escritório Internacional, aquela ou aquelas das Administrações que serão competentes para proceder ao exame preliminar.

3) As disposições do artigo 16.3) aplicar-se-ão, mutatis mutandis, às Administrações encarregadas do exame preliminar internacional.

\section{Artigo 33}

Exame preliminar internacional

1) O exame preliminar internacional tem por objeto formular uma opinião preliminar e sem compromisso sobre as questões de saber se a invenção cuja proteção é solicitada, parece ser nova, implicar uma atividade inventiva (não ser evidente) e ser suscetível de aplicação industrial.

2) Para fins do exame preliminar internacional, a invenção cuja proteção é solicitada é considerada como nova desde que não exista anterioridade no estado da técnica tal como é definida no Regulamento de execução.

3) Para fins do exame preliminar internacional, a invenção cuja proteção é solicitada é considerada como implicando uma atividade inventiva, desde que, levando-se em conta o estado da técnica tal 
como é definido no Regulamento de execução, ela não seja evidente, na data pertinente estabelecida, para um profissional do ramo.

4) Para fins do exame preliminar internacional à invenção cuja proteção é solicitada é considerada como suscetível de aplicação industrial desde que, de acordo com sua natureza, possa ser produzida ou utilizada (no sentido tecnológico) em toda espécie de indústria. O termo «indústria» deverá ser interpretado no seu sentido mais lato, como na Convenção de París para a Proteção da Propriedade Industrial.

5) Os critérios precedente não servem senão para fins do exame preliminar internacional. Qualquer Estado contratante poderá aplicar critérios adicionais ou diferentes a fim de decidir se, nesse Estado, a invenção pode ou não ser patenteada.

6) O exame preliminar internacional deverá levar em consideração todos os documentos citados no relatório de pesquisa internacional. Poderá levar em consideração todos os documentos adicionais que julgar pertinentes no caso. no caso em espécie.

\section{Artigo 34}

Procedimento junto à Administração encarregada do exame preliminar Internacional

1) O procedimento junto à Administração encarregada do exame preliminar internacional é determinado pelo presente Tratado, pelo Regulamento de execução e pelo acordo que o Escritório Internacional concluir, de acordo com o presente Tratado e com o Regulamento de execução, com essa Administração.

2)a) O depositante tem o direito de se comunicar, verbalmente e por escrito, com a Administração encarregada do exame preliminar internacional.

b) O depositante tem o direito de modificar as reinvidicações, a descrição e os desenhos, na forma estabelecida e dentro do prazo prescrito, antes do estabelecimento do relatório de exame preliminar internacional. As modificações não devem ir além da exposição da invenção constante do pedido internacional tal como foi depositado.

c) O depositante receberá da Administração encarregada do exame preliminar internacional pelo menos um aviso por escrito, a menos que a citada Administração julgue que todas as condições abaixo foram satisfeitas:

I) a invenção corresponde aos critérios fixados pelo artigo 33.1);

II) o pedido internacional preenche as condições do presente Tratado e do Regulamento de execução na medida em que são controladas pela citada Administração;

III) não se cogita de apresentar observações no sentido do artigo 35.2), última frase.

d) O depositante poderá responder ao aviso por escrito.

3)a) Se a Administração encarregada do exame preliminar internacional julgar que o pedido internacional não satisfaz a exigência de unidade da invenção tal como é definida no Regulamento de execução poderá solicitar ao depositante, à escolha deste último, quer que limite as reinvindicações de modo a satisfazer essa exigência, quer que pague as taxas adicionais.

b) A legislação nacional de qualquer Estado eleito poderá prever, quanto o depositante preferir limitar as reinvindicações de acordo com a alínea $a$ ), que as partes do pedido internacional que, em conseqüência da limitação, não constituam objeto de um exame preliminar internacional sejam consideradas, no que diz respeito aos efeitos nesse Estado, como retiradas a menos que uma taxa especial seja paga pelo depositante à Repartição Nacional do dito Estado.

c) Se o depositante não atender à solicitação mencionada na alínea $a$ ) dentro do prazo estipulado, a Administração encarregada do exame preliminar internacional fará um relatório de exame preliminar sobre as partes do pedido internacional que dizem respeito ao que pareça constituir a 
invenção principal fornecendo indicações sobre esse particular no relatório. A legislação nacional de qualquer Estado eleito poderá prever, quando a Repartição nacional desse Estado julgar justificada a solicitação da Administração encarregada do exame preliminar internacional, que as partes do pedido internacional que não digam respeito à invenção principal sejam, no que concerne aos efeitos nesse Estado, consideradas como retiradas, a menos que uma taxa especial seja paga pelo depositante a essa Repartição.

4) a) Se a Administração encarregada do exame preliminar internacional julgar:

I) que o pedido internacional diz respeito a um objeto a respeito do qual não lhe compete, de acordo com o Regulamento de execução, efetuar um exame preliminar internacional e decidir no caso não proceder a esse exame, ou

II) que a descrição, as reivindicações ou os desenhos não são claros, ou que as reivindicicações não se fundam de forma adequada na descrição, de maneira que possa ser formada uma opinião válida quanto à questão de novidade, da atividade inventiva (não-evidência) ou da aplicação industrial da invenção cuja proteção é solicitada, ela não abordará as questões mencionadas no artigo 33.1) e dará a conhecer ao depositante essa opinião e seus motivos.

b) Se qualquer uma das hipóteses mencionadas na alínea $a$ ) não ocorrer senão a respeito de certas reivindicações ou em relação a certas reivindicações, as disposições da citada alínea $a$ ) não se aplicarão senão a respeito dessas reivindicações.

\section{Artigo 35}

Relatório de exame preliminar Internacional

1) O relatório de exame preliminar Internacional será estabelecido dentro do prazo e na forma prescritos.

2) O relatório de exame preliminar internacional não conterá nenhuma declaração respectiva à questão de saber se a invenção cuja proteção é solicitada faz ou parece fazer jus ou não a patente a respeito de uma legislação nacional qualquer. Declarará, ressalvado o parágrafo 3), em relação a cada reivindicação, se essa reivindicação parece corresponder aos critérios de novidades, atividade inventiva (não-evidência) e aplicação industrial, tal como esses critérios são definidos, para fins do exame preliminar internacional, no artigo 33.1) a 4) Essa declaração deverá ser acompanhada por uma citação dos documentos que apoiam a conclusão declarada e por todas explicações que se imponham no caso. A essa declaração deverão igualmente ser juntadas as demais observações previstas pelo Regulamento de execução.

3)a) Se a Administração encarregada do exame preliminar internacional julgar, na ocasião do fornecimento do relatório de exame preliminar internacional, que qualquer uma das hipóteses mencionadas no artigo 34.4)a) ocorreu, o relatório o consignará explicando os motivos. Não deverá conter qualquer declaração do tipo descrito no parágrafo 2).

b) Se qualquer uma das hipóteses mencionadas no artigo 34.4)b) ocorrer, o relatório de exame preliminar internacional conterá, a respeito das reivindicações em questão, a indicação prevista na alínea a) e, quanto às demais reivindicações, a declaração mencionada no parágrafo 2).

\section{Artigo 36}

Transmissão, tradução e comunicação do relatório de exame preliminar internacional

1) O relatório de exame preliminar internacional será, juntamente com os anexos determinados, transmitido ao depositante e ao Escritório Internacional.

2)a) O relatório de exame prelominar intenacional e seus anexos serão traduzidos nas línguas prescritas.

b) Todas as traduções do citado relatório serão preparadas pelo Escritório Internacional ou sob sua responsabilidade; todas as traduções de seus anexos serão preparadas pelo depositante. 
3)a) O relatório de exame preliminar internacional, com sua tradução (tal qual ela for prescrita) e seus anexos (na língua original), será comunicado pelo Escritório Internacional a cada Repartição eleita.

b) A tradução prescrita para os anexos será trasnmitida, dentro do prazo prescrito, pelo depositante para as Repartições eleitas.

4) $\mathrm{O}$ artigo 20.3) aplica-se, mutatis mutandis, às cópias de todo documento citado no relatório de exame preliminar internacional e que não tenham sido citado no relatório de pesquisa internacional.

\section{Artigo 37}

Retirada do pedido de exame preliminar internacional ou de eleições

1) O depositante poderá retirar todas ou parte das eleições.

2) Se a eleição de todos os Estados for retirada, considerar-se-á o pedido como retirado.

3)a)Toda retirada deverá ser notificada ao Escritório Internacional.

b) As Repartições eleitas interessadas e a Administração competente encarregada do exame preliminar internacional serão notificadas correspondentemente pelo Escritório Internacional.

4)a) Com ressalva da alínea $b$ ), a retirada do pedido de exame preliminar internacional ou da eleição de um Estado contratante, salvo disposição em contrário da legislação nacional do Estado em questão, será considerada como retirada do pedido internacional do que se refere a esse Estado.

b) A retirada do pedido de exame preliminar internacional ou da eleição não será considerada como retirada do pedido internacional se ela ocorrer antes da expiração do prazo aplicável segundo o artigo 22; todavia, todo Estado contratante poderá prever em sua legislação nacional que o acima exposto somente será válido, si a sua Repartição nacional receber, dentro desse prazo, cópia do pedido internacional, junto com uma tradução (como prescrito) e a taxa nacional.

\section{Artigo 38}

Caráter confidencial do exame preliminar internacional

1) Salvo requerimento ou autorização do depositante, o Escritório Internacional e a Administração competente encarregada Do exame preliminar internacional não poderão, em momento algum, permitir a qualquer pessoa ou administração - com exceção das Repartições eleitas, depois do estabelecimento do relatório de exame preliminar internacional - acesso, nos termos e sentido do artigo 30.4), ao dossier do exame preliminar internacional.

2) Com ressalva do parágrafo 1) e dos artigos 36.1) e 3) e 37.3)b), o Escritório Internacional e a Administração competente encarregada do exame preliminar internacional não poderão dar, salvo requerimento ou autorização do depositante, qualquer informação relativa à expedição ou nãoexpedição de um relatório de exame preliminar internacional e retirada ou não-retirada do pedido de exame preliminar internacional, ou de qualquer eleição.

\section{Artigo 39}

Cópias, traduções e taxas para as Repartições eleitas

1)a) Se a eleição de um Estado contratante for realizada antes da expiração do décimo nono mês a contar da data de prioridade, o artigo 22 não se aplicará a esse Estado; o depositante remeterá a cada Repartição eleita uma cópia do pedido internacional (exceto se a comunicação a que se refere o artigo 20 já houver sido feita) e uma tradução (tal como for prescrito) desse pedido e lhe pagará (se for o caso) a taxa nacional, o mais tardar ao expirar um prazo de vinte e cinco meses contados da data de prioridade.

b) Qualquer legislação nacional poderá, a fim de executar os atos a que se refere a alínea $a$ ), fixar prazos que expirem depois daquele que figura na cidade alínea. 
2) Os efeitos previstos no artigo 11.3) cessarão no Estado eleito com as mesmas consequências que as que decorrem da retirada de um pedido nacional nesse Estado, se o depositante deixar de executar os atos a que se refere o parágrafo 1)a) dentro do prazo aplicável de acordo com o parágrafo 1)a) ou b).

3) Qualquer Repartição eleita poderá manter os efeitos previstos no artigo 11.3) mesmo quando o depositante não preenche as condições previstas no parágrafo 1)a) ou b).

\section{Artigo 40}

Suspensão do exame nacional e dos demais processos

1) Se a eleição de um Estado contratante for efetuada antes de expirado o décimo nono mês a contar da data de prioridade, o artigo 23 não se aplicará a esse Estado e sua repartição nacional ou qualquer Repartição agindo em nome desse Estado não efetuará o exame e não iniciará qualquer outro processo relativo ao pedido internacional, com ressalva do parágrafo 2), antes de expirado o prazo aplicável de acordo com o artigo 39.

2) Não obstante as disposições do parágrafo 1), qualquer repartição eleita, a pedido expresso do depositante, poderá proceder a qualquer época ao exame e iniciar qualquer outro processo referente ao pedido internacional.

\section{Artigo 41}

Modificação das reivindicações, da descrição e dos desenhos

Nas Repartições eleitas

1) O depositante deverá Ter oportunidade de modificar as reinvindicações, a descrição e os desenhos, dentro do prazo previsto, em cada Repartição eleita. Nenhuma Repartição eleita poderá conceder patente, nem se recusar a concedê-la antes de expirado esse prazo, salvo autorização expressa do depositante.

2) As modificações não devem ir além da exposição da invenção que consta do pedido internacional, tal como foi depositado, salvo se a legislação nacional do Estado eleito o permitir expressamente.

3) As modificações deverão respeitar a legislação nacional do Estado eleito em tudo quanto não for disposto neste Tratado ou no Regulamento de execução.

4) Quando a Repartição eleita exigir uma tradução do pedido internacional, as modificações deverão ser feitas na mesma língua da tradução.

\section{Artigo 42}

Resultado do exame nacional das Repartições eleitas

As Repartições eleitas que receberem o relatório de exame preliminar internacional não poderão exigir que o depositante lhes remeta cópias de documentos anexos ao exame relativo ao mesmo pedido internacional em qualquer outra Repartição eleita, ou que ele lhes remeta informações relativas ao conteúdo de tais documentos. 


\section{CAPÍTULO III}

\section{Disposições Gerais}

\section{Artigo 43}

Requerimento de certos títulos de proteção

O depositante poderá indicar, de acordo com o Regulamento de execução, que seu pedido internacional visa à concessão de um certificado de autor de invenção, de um certificado de utilidade ou de um modelo de utilidade e não à de uma patente, ou à concessão de uma patente ou certificado de adição, de um certificado de autor de invenção adicional ou de um certificado de utilidade adicional, em qualquer Estado designado ou eleito cuja legislação preveja a concessão de certificados de autor de invenção, de certificados de utilidade, de modelos de utilidade, de patentes ou certificados de adição, de certificados de autor de invenção adicionais ou de certificados de utilidade adicionais; os efeitos decorrentes dessa indicação serão determinados pela escolha efetuada pelo depositante. Para fins deste artigo e de qualquer regra que se lhe refira, o artigo 2.ii) não será aplicável.

\section{Artigo 44}

Requerimento de dois títulos de proteção

A fim de que qualquer Estado designado ou eleito, cuja legislação permita que um pedido visando à concessão de uma patente ou qualquer um dos outros títulos de proteção mencionados no artigo 43 possa visar igualmente a um outro desses títulos de proteção, o depositante poderá indicar, de acordo com o Regulamento de execução, os dois títulos de proteção cuja concessão ele requer; os efeitos decorrentes serão determinados pelas indicações do depositante. Para fins deste artigo o artigo 2.ii) não será aplicável.

\section{Artigo 45}

Tratados de patentes regionais

Qualquer tratado que disponha sobre a concessão de uma patente regional («tratado de patente regional») e conceda a qualquer pessoa autorizada pelo artigo 9 a depositar pedidos internacionais, o direito de depositar pedidos visando à concessão de tais patentes, poderá estipular que os pedidos internacionais contendo a designação ou a eleição de um Estado signatário ao mesmo tempo do tratado de patente regional e do presente Tratado, sejam depositados com vistas à concessão de patentes regionais.

2) A legislação nacional de um tal Estado designado ou eleito poderá prever que qualquer designação ou eleição do citado Estado no pedido iternacional seja considerada como indicação de que o depositante deseja obter uma patente regional de acordo com o tratado de patente regional.

\section{Artigo 46}

Tradução incorreta do pedido internacional

Se, em virtude de uma tradução incorreta do pedido internacional, o alcance de uma patente concedida em decorrência desse pedido ultrapassar o alcance do pedido internacional em sua língua original, as autoridades competentes do Estado contratante considerado poderão limitar em consequência e de forma retroativa o alcance da patente e declarar que é nula na medida que seu alcance ultrapasse o do pedido internacional em sua língua original. 


\section{Artigo 47}

\section{Prazos}

1) O cálculo dos prazos previstos neste Tratado será determinado pelo Regulamento de execução.

2)a) Todos os prazos estabelecidos nos Capítulos I e II deste Tratado poderão, fora de qualquer revisão de acordo com o artigo 60, ser modificados por decisão dos Estados contratantes.

b) A decisão é tomada pela Assembléia ou por voto por correspondência e deverá ser unânime.

c) Os pormenores do processo serão estabelecidos pelo Regulamento de execução.

\section{Artigo 48}

Atrasos na observância de certos prazos

1) Quando um prazo estabelecido por este Tratado ou pelo Regulamento de execução não for observado em virtude de interrupção dos serviços postais, de perda ou atraso inevitáveis do correio, esse prazo será considerado como observado nos casos previstos pelo Regulamento de execução e com a ressalva de que deverão ser preenchidas as condições de prova e outras condições prescritas pelo dito Regulamento.

2)a) Qualquer Estado contratante deverá, no que lhe diz respeito, desculpar por motivos permitidos por sua legislação nacional qualquer atraso na observância de um prazo.

b) Qualquer Estado contratante poderá, no que lhe diz respeito, desculpar por motivos outros que os mencionados na alínea $a$ ) qualquer atraso na observância de um prazo.

\section{Artigo 49}

Direito de exercer junto a Administrações internacionais

Qualquer advogado, agente de patentes ou outra pessoa que tenha o direito de exercer junto à Repartição nacional em que o pedido internacional foi depositado, terá o direito de exercer, no que concerne a esse pedido, junto ao Escritório Internacional, à Administração competente encarregada da pesquisa internacional e à Administração competente encarregada do exame preliminar internacional.

\section{CAPÍTULO IV}

\section{Serviços Técnicos}

\section{Artigo 50}

Serviços de informação sobre patentes

1) O Escritório Internacional poderá fornecer serviços (neste artigo denominados «serviços de informação»), para o fornecimento de informações técnicas e outras informações pertinentes de que dispuser, à base de documentos publicados, principalmente de patentes e pedidos publicados.

2) O Escritório Internacional poderá fornecer esses serviços de informação quer diretamente, quer por intermédio de uma ou várias Administrações encarregadas da pesquisa interncional ou de outras instituições especializadas, nacionais ou internacionais, com as quais houver conseguido concluir acordos.

3) Os serviços de informação funcionarão de maneira a facilitar muito particularmente a aquisição, pelos Estados contratantes que sejam países em via de desenvolvimento, de conhecimentos técnicos e da tecnologia, inclusive o «know-how» publicado disponível. 
4) Os serviços de informação poderão ser obtidos pelos governos dos Estados contratantes, por seus nacionais e pelas pessoas domiciliadas em seu território. A Assembléia poderá decidir ampliar esses serviços a outros interessados.

5)a) Qualquer serviço fornecido aos governos dos Estados contratantes deverá sê-lo pelo preço de custo; entretanto para os governos dos Estados contratantes que sejam países em desenvolvimento, o serviço será fornecido abaixo desse custo, caso a diferença possa ser coberta pelos benefícios realizados com a prestação de serviço a destinatários outros que os governos de Estados contratantes ou pelos meios mencionados no artigo 51.4).

b) O preço de custo a que se refere a alínea $a$ ) deverá ser interpretado como consistindo nas despesas acrescidas às que a Repartição nacional ou a Administração encarregada da pesquisa internacional tiverem de incorrer necessariamente para executar suas tarefas.

6) Os pormenores relativos à aplicação deste artigo serão regulamentados por decisões de Assembléia e, nos limites que esta fixar, pelos grupos de trabalho que ela vier a constituir para esse fim.

7) Se assim o julgar necessário, a Assembléia recomendará outras modalidades de financiamento para completar as já estabelecidas no parágrafo 5).

\section{Artigo 51}

\section{Assistência Técnica}

1) A Assembléia instituirá um Comitê de Assistência Técnica (denominado no presente artigo «o Comitê»).

2)a) Os membros do Comitê serão eleitos entre os Estados contratantes de modo a assegurar uma representação adequada dos países em via de desenvolvimento.

b) O Diretor-Geral convidará, por iniciativa própria ou a pedido do Comitê, representantes das organizações governamentais que se dediquem à assistência técnica aos países em via de desenvolvimento para tomar parte nos trabalhos do Comitê.

3)a) O Comitê será encarregado da organização e da supervisão da assistência técnica prestada aos Estados contratantes que sejam países em via de desenvolvimento, a fim de desenvolver seus sistemas de patentes, quer no nível nacional, quer no regional.

b) A assistência técnica compreenderá, entre outros, a formação de especialistas, o preparo de técnicos e o fornecimento de equipamentos para demonstração e operação.

4) Em vista do financiamento de projetos incluídos no âmbito deste artigo, o Escritório Internacional fará todo o possível para concluir acordos, de um lado, com organizações intrnacionais de financiamento e organizações intergovernamentais, particularmente com a Organização das Nações Unidas, as agências das Nações Unidas assim como com as instituições especializadas das Nações Unidas com competência em questões de assistência técnica, assim como, de outro lado, com os governos dos Estados beneficiários da assistência técnica.

5) Os pormenores relativos à aplicação do presente artigo serão regulamentados por decisões da Assembléia e, nos limites fixados por esta última, pelos grupos de trabalho que ela vier a instituir para esse fim.

\section{Artigo 52}

Relações com outras disposições do Tratado

Nenhuma disposição deste Capítulo afetará as disposições financeiras contidas nos demais Capítulos deste Tratado. Essas disposições não se aplicam a este Capítulo nem à sua execução. 


\section{CAPÍTULO V}

Disposições Administrativas

\section{Artigo 53}

Assembléia

1)a) A Assembléia será constituída pelos Estados contratantes, ressalvado o artigo 57.8).

b) O governo de cada Estado contratante será representado por um delegado, que poderá ser assistido por suplentes, conselheiros e técnicos.

2)a) A Assembléia:

I) tratará de todas as questões referentes à manutenção e ao desenvolvimento da União e à aplicação deste Tratado;

II) desempenhará as funções que lhe forem expressamente designadas em outras disposições deste Tratado;

III) fornecerá ao Escritório Internacional diretrizes sobre o preparo das conferências de revisão;

IV) examinará e aprovará os relatórios e as atividades do Diretor-Geral relativos à União e lhe fornecerá diretrizes úteis sobre questões da competência da União;

V) examinará e aprovará os relatórios e as atividades do Comitê Executivo constituído de acordo com o parágrafo 9) e lhe fornecerá diretrizes;

VI) decidirá sobre o programa, adotará o orçamento trienal da União e aprovará suas contas de encerramento;

VII) adotará o regulamento financeiro da União;

VIII) criará os comitês e grupos de trabalho que julgar úteis à realização dos objetivos da União;

IX) decidirá quais Estados não-contratantes e, ressalvado o parágrafo 8), quais organizações intergovernamentais e internacionais não governamentais poderão ser admitidos às suas reuniões na qualidade de observadores;

X) empreenderá qualquer outra ação apropriada à consecução dos objetivos da União e executará quaisquer outras funções úteis no âmbito deste Tratado.

b) A respeito de questões que interessem igualmente outras Uniões administradas pela Organização, a Assembléia estatuirá depois de ouvido o Comitê de Coordenação da Organização.

3) Um delegado não poderá representar senão um único Estado e não poderá votar senão em nome deste.

4) Cada Estado contratante disporá de um voto.

5)a) A metade dos Estados contratantes constituirá quorum.

b) Se esse quorum não for atingido, a Assembléia poderá decidir; entretanto, tais decisões, com exceção daquelas que dizem respeito a seu procedimento, não se tornarão executórias a menos que o quorum e a maioria requerida sejam atingidos por meio do voto por correspondência previsto no Regulamento de execução.

6)a) Com ressalva dos artigos 47.2)b), 58.2)b), 58.3) e 61.2)b), as decisões da Assembléia serão tomadas com uma maioria de dois terços dos votos expressos.

b) A abstenção não será considerada como um voto. 
7) Caso se trate de questões do interesse exclusivo dos Estados que incorrem nas disposições do Capítulo II, qualquer referência aos Estados contratantes que figurem nos parágrafos 4), 5) e 6) será considerada como aplicável unicamente aos Estados configurados no Capítulo II.

8) Qualquer organização intergovernamental nomeada como Administração encarregada da pesquisa internacional ou como Administração encarregada do exame preliminar internacional será admitida como observadora nas reuniões da Assembléia.

9) Quando o número de Estados contratantes ultrapassar quarenta, a Assembléia estabelecerá um Comitê Executivo. Qualquer referência feita ao Comitê Executivo no presente Tratado ou no Regulamento de execução indicará a época em que esse Comitê foi estabelecido.

10) Enquanto não for estabelecido o Comitê Executivo, a Assembléia se pronunciará, nos limites do programa e do orçamento trienal, sobre os programas e orçamentos anuais preparados pelo Diretor-Geral.

11)a) Enquanto não for estabelecido o Comitê Executivo, a Assembléia se reunirá uma vez por ano em sessão ordinária, por convocação do Diretor-Geral e, salvo em casos excepcionais, durante o mesmo período e no mesmo local que o Comitê de Coordenação da Organização.

b) Depois do estabelecimento do Comitê Executivo, a Assembléia se reunirá uma vez cada três anos em sessão ordinária, por convocação do Diretor-Geral e, salvo em casos excepcionais, durante o mesmo período e no mesmo local que a Assembléia Geral da Organização.

c) A Assembléia se reunirá em sessão extraordinária por convocação expedida pelo Diretor-Geral, a pedido do Comitê Executivo ou a pedido de um quarto dos Estados contratantes.

12) A Assembléia adotará seu regulamento interno.

\section{Artigo 54}

\section{Comitê Executivo}

1) Depois que a Assembléia houver estabelecido um Comitê Executivo, o mesmo ficará sujeito às seguintes disposições;

2)a) Ressalvado o artigo 57.8), o Comitê será constituído pelos Estados eleitos pela Assembléia dentre os Estados membros desta última.

b) O governo de cada Estado membro do Comitê Executivo será representado por um delegado, que poderá ser assistido por suplentes, conselheiros e técnicos.

3) O número dos Estados membros do Comitê Executivo corresponderá a um quarto do número dos Estados membros da Assembléia. No cálculo dos assentos a serem estabelecidos, o saldo restante após a divisão por quatro não será levado em consideração.

4) Na ocasião da eleição dos membros do Comitê Executivo a Assembléia levará em consideração uma repartição geográfica equitativa.

5)a) Os membros do Comitê Executivo permanecerão em seus postos a partir do encerramento da sessão da Assembléia durante a qual foram eleitos até o fim da sessão ordinária seguinte da Assembléia.

b) Os membros do Comitê Executivo serão reelegíveis num limite máximo de dois terços deles.

c) A Assembléia regulamentará as modalidades da eleição e da reeleição eventual dos membros do Comitê Executivo.

6)a) O Comitê Executivo:

I) preparará o projeto de ordem do dia da Assembléia; 
II) submeterá à Assembléia propostas relativas aos projetos de programa e de orçamento trienal da União preparados pelo Diretor-Geral;

III) pronunciar-se-á, dentro dos limites do programa e do orçamento trienal, sobre os programas e orçamentos anuais preparados pelo Diretor-Geral;

IV) submeterá à Assembléia, com os comentários apropriados, os relatórios periódicos do DiretorGeral e os relatórios anuais de exames de contas;

V) tomará todas as medidas úteis necessárias à execução do programa da União pelo DiretorGeral, de acordo com as decisões da Assembléia, levando em conta as circunstâncias surgidas entre duas sessões ordinárias da dita Assembléia;

V) executará todas as demais tarefas que lhe forem atribuídas no âmbito deste Tratado.

b) Sobre as questões que interessem igualmente outras uniões administradas pela Organização, o Comitê Executivo estatuirá depois de ouvido o Comitê de Coordenação da Organização.

7)a) O comitê Executivo reunir-se-á uma vez por anos em sessão ordinária, por convocação do Diretor-Geral, tanto quanto possível durante o mesmo período e no mesmo local que o Comitê de Coordenação da Organização.

b) O comitê Executivo reunir-se-á em sessão extraordinária, por convocação expedida pelo Diretor-Geral, quer por iniciativa deste último, quer a pedido de seu presidente ou de um quarto de seus membros.

8)a) Cada Estado membro do Comitê Executivo disporá de um voto.

b) A metade dos Estados membros do Comitê Executivo constituirá quorum.

c) As decisões serão tomadas por maioria simples dos votos expressos.

d) A abstenção não será considerada como um voto.

e) um delegado não poderá representar senão um único Estado e não poderá votar senão em nome do mesmo.

9) Os Estados contratantes que não forem membros do Comitê Executivo serão admitidos a suas reuniões na qualidade de observadores, assim como qualquer organização intergovernamental nomeada como Administração encarregada da pesquisa internacional ou como Administração encarregada do exame preliminar internacional.

10) O Comitê Executivo adotará seu regulamento interno.

\section{Artigo 55}

Escritório Internacional

1) As Tarefas administrativas que competem à União serão desempenhadas pelo Escritório Internacional.

2) O Escritório Internacional determinará o secretariado dos diversos órgãos da União.

3) O Diretor-Geral será o mais alto funcionário da União e seu representante.

4) O Escritório Internacional publicará uma Gazeta e outras publicações previstas pelo Regulamento de execução ou pela Assembléia.

5) O Regulamento de execução discriminará os serviços que as Repartições nacionais deverão prestar a fim de prestar assistência ao Escritório Internacional, às Administrações encarregadas da pesquisa internacional e às Administrações encarregadas do exame preliminar internacional na execução das tarefas determinadas por este Tratado. 
6) O Diretor-Geral e qualquer membro do quadro de pessoal que ele designar, tomarão parte, sem direito a voto, em todas as reuniões da Assembléia, do Comitê Executivo e de qualquer outro comitê ou grupo de trabalho criado em função deste Tratado ou do Regulamento de execução. O Diretor-Geral, ou um membro do quadro de pessoal que ele designar, será, por direito de ofício, secretário desses órgãos.

7)a) O Escritório Internacional preparará as conferências de revisão de acordo com as diretrizes da Assembléia e em cooperação com o Comitê Executivo.

b) O Escritório Internacional poderá consultar organizações intergovernamentais e internacionais não governamentais sobre o preparo das conferências de revisão.

c) O Diretor-Geral e as pessoas por ele designadas, tomarão parte, sem direito a voto, nas deliberações das conferências de revisão.

8) O Escritório Internacional executará todas as demais tarefas que lhe forem atribuídas.

\section{Artigo 56}

Comitê de Cooperação Técnica

1) A Assembléia estabelecerá um Comitê de Cooperação Técnica (denominado neste artigo «o Comitê»).

2)a) A Assembléia determinará a composição do Comitê e lhe nomeará os membros, levando em conta uma representação equitativa dos países em via de desenvolvimento.

b) As Administrações encarregadas da pesquisa internacional ou do exame preliminar internacional serão membros ex officio do Comitê. Quando uma tal Administração for a Repartição nacional de um Estado contratante, este não poderá ter outro representante no Comitê.

c) Se o número dos Estados contratantes o permitir, o número total dos membros do Comitê será superior ao dobro do número dos membros ex officio.

d) O Diretor-Geral, por iniciativa própria ou a pedido do Comitê, convidará representantes das organizações interessadas em participarem das discussões que lhes parecerem importantes;

3) O comitê tem por fim contribuir, por meio de avisos e recomendações:

I) para melhorar constantemente os serviços previstos por este Tratado;

II) para obter, tendo em vista a existência de várias administrações encarregadas da pesquisa internacional e de várias Administrações encarregadas do exame preliminar internacional, que sua documentação e seus métodos de trabalho sejam tão uniformes quanto possível e que seus relatórios sejam uniformemente da melhor qualidade possível;

III) a convite da Assembléia ou do Comitê Executivo, para resolver os problemas técnicos especialmente apresentados pela instituição de uma única Administração encarregada da pesquisa internacional.

4) Qualquer Estado contratante e qualquer organização internacional interessada poderão incumbir o Comitê, por escrito, de questões de sua competência.

5) O Comitê poderá remeter seus avisos e suas recomendações ao Diretor-Geral ou por intermédio deste último, à Assembléia, ao Comitê Executivo, a todas as Administrações encarregadas da pesquisa internacional ou do exame preliminar internacional ou a algumas delas e a todas as Repartições receptoras ou a algumas delas.

6)a) O Diretor-Geral remeterá sempre ao Comitê Executivo o texto de todos os avisos e recomendações do Comitê. Poderá juntar aos mesmos seus comentários.

b) O Comitê Executivo poderá expressar suas opiniões a respeito de qualquer aviso ou recomendação ou a respeito de qualquer outra atividade do Comitê e poderá solicitar a este último 
que estude questões de sua competência e a apresentar um relatório sobre as mesmas. O Comitê Executivo poderá submeter à Assembléia, com comentários apropriados, os avisos, recomendações e relatórios do Comitê.

7) Enquanto não for estabelecido o Comitê Executivo, as referências ao mesmo, a que se refere o parágrafo 6) serão consideradas como referentes à Assembléia.

8) A Assembléia sobre os pormenores relativos ao procedimento do Comitê.

\section{Artigo 57}

Finanças

1)a) A União terá um orçamento.

b) O orçamento da União compreenderá as receitas e as despesas próprias da União assim como sua contribuição para o orçamento das despesas comuns às Uniões administrativas pela Organização.

c) Serão consideradas como despesas comuns às Uniões as despesas que não forem atribuídas exclusivamente à União, mas também a uma ou várias outras Uniões administrativas pela Organização.

A parte da União nessas despesas comuns será proporcional ao interesse que tais despesas lhe apresentarem.

2) O orçamento da União será determinado, levando em conta as exigências de coordenação com os orçamentos das outras Uniões administrativas pela Organização.

3) Ressalvado o parágrafo 5), o orçamento da União será financiado pelos seguintes recursos:

I) as taxas e quantias devidas pelos serviços prestados pelo Escritório Internacional à conta da União;

II) o produto da venda das publicações do Escritório Internacional a respeito da União e os direitos tocantes a essas publicações;

III) as doações, os legados e as subvenções;

IV) os aluguéis, juros e rendimentos diversos.

4) O montante das taxas e quantias devidas ao Escritório Internacional assim como o preço de venda de suas publicações, serão fixados de modo a cobrir normalmente todas as despesas causadas ao Escritório Internacional pela administração deste Tratado.

5)a) Caso um exercício orçamentário seja encerrado com défice, os Estados membros, ressalvadas as alíneas $b$ ) e $c$ ), fornecerão contribuições para cobrir esse défice.

b) A Assembléia determinará a contribuição de cada Estado contratante, levando na devida conta o número de pedidos internacionais remetidos por cada um deles no decorrer do ano em questão.

c) Se o défice puder ser coberto provisoriamente no todo ou em parte ou por outros meios, a Assembléia poderá resolver comunicá-los e não solicitar contribuições aos Estados contratantes.

d) Se a situação financeira da União o permitir, a Assembléia poderá decidir que todas as contribuições feitas de acordo com a alínea $a$ ) sejam reembolsadas aos Estados contratantes que as tiverem feito.

e) Se algum Estado contratante não houver fornecido sua contribuição conforme a alínea $b$ ) dentro de um prazo de dois anos contados da data em que foi exigida por decisão da Assembléia, não poderá exercer seu direito de voto em nenhum dos órgãos da União. Entretanto, qualquer órgão da União poderá autorizar um tal Estado a conservar o exercício de seu direito de voto dentro do dito 
órgão enquanto este último julgar que o atraso for decorrente de circunstâncias excepcionais e enevitáveis.

6) No caso de o orçamento não ser adotado antes do início de um novo exercício, o orçamento do ano precedente será renovado de acordo com as modalidades previstas pelo regulamento financeiro.

7)a) A União possuirá um fundo rotativo constituído por um único depósito efetuado por cada Estado contratante. Se o fundo vier a ser deficiente, a Assembléia tomará as medidas necessárias a seu preencimento. Se uma parte desse fundo não for mais necessária, será reembolsada aos Estados contratantes.

b) O montante do depósito inicial de cada Estado contratante no fundo citado acima, ou de sua participação no seu aumento será fixado pela Assembléia de acordo com princípios semelhantes aos previstos no parágrafo 5)b).

c) As modalidades do depósito serão determinadas pela Assembléia por proposta do Diretor- Geral e depois de consultado o Comitê de Coordenação da Organização.

d) Todos os depósitos serão proporcionais aos montantes depositados por cada Estado contratante, levando-se em conta as datas desses depósitos.

8)a) O acordo de sede concluído com o Estado no território do qual a Organização tem sua sede prevê que, se o fundo rotativo for insuficiente, esse Estado concederá adiantamentos. O montante desses adiantamentos e as condições em que os mesmos são concedidos serão objeto, em cada caso, de acordos separados entre o Estado em causa e a Organização. Enquanto estiver comprometido a conceder adiantamentos esse Estado disporá, ex officiode um assento na Assembléia e no Comitê Executivo.

b) O Estado a que se refere a alínea $a$ ) e a Organização, terão, cada qual, direito de declarar o compromisso de conceder adiantamentos por meio de aviso escrito. A declaração terá efeito três anos após o fim do ano durante o qual ela foi notificada.

9) O exame das contas será determinado, de acordo com as modalidades previstas pelo regulamento financeiro, por um ou vários Estados contratantes ou por fiscais externos. Serão, com o seu consentimento, designados pela Assembléia.

\section{Artigo 58}

Regulamento de execução

1) O Regulamento de execução, anexo ao presente Tratado, contém regras relativas:

I) a questões a respeito das quais o presente Tratado reporta expressamente ao Regulamento de execução ou estabelece expressamente que constituam ou constituirão objeto de prescrições;

II) a qualquer requisito, assunto ou procedimento de ordem administrativa;

III) a qualquer pormenor útil à execução das disposições deste Tratado.

2)a) A Assembléia poderá modificar o Regulamento de execução.

b) Ressalvado o parágrafo 3), as modificações exigirão a maioria de três quartos dos votos expressos.

3)a) O Regulamento de execução especificará as regras que só poderão ser modificadas:

I) por decisão unânime, ou

II) se não houver surgido qualquer desacordo quer de parte de um dos Estados contratantes cuja Repartição nacional funcione como Administração encarregada da pesquisa internacional ou do exame preliminar internacional, quer, quando uma tal Administração for uma organização intergovernamental, de parte do Estado contratante membro dessa organização com mandato dos 
demais Estados membros reunidos no organismo competente dessa organização, especificamente para esse fim.

b) A fim de que qualquer uma dessas regras possa ser eximida no futuro das exigências determinadas, será necessário que as condições estabelecidas na alínea $a$ )I) ou a)II) tenham sido preenchidas.

c) A fim de que qualquer regra possa ser incluída no futuro em que uma ou outra das categorias mencionadas na alínea $a$ ), será necessário um consentimento unânime.

4) O Regulamento de execução determinará que o Direto-Geral baixe Instruções Administrativas sob o controle da Assembléia.

5) Em caso de discrepância entre o texto do Tratado e do Regulamento de execução, prevalecerá o primeiro.

\section{CAPÍTULO VI}

\section{Divergências}

\section{Artigo 59}

\section{Divergências}

Ressalvado o artigo 64.5) qualquer divergência entre dois ou mais Estados contratantes a respeito da interpretação ou a aplicação do presente Tratado e do Regulamento de execução que não seja resolvida por meio de negociação, poderá ser levada por qualquer um dos Estados em causa à Corte Internacional de Justiça por meio de petição, de acordo com os Estatutos da Corte, a menos que os Estados em causa concordem com outra forma de solução. O Escritório Internacional será notificado pelo Estado contratante requerente da divergência submetida à Corte, assim informando os demais Estados contratantes.

\section{CAPÍTULO VII}

Revisão e Modificações

\section{Artigo 60}

Revisão do Tratado

1) O presente Tratado poderá sofrer revisões periódicas, por meio de conferências especiais dos Estados contratantes.

2) A convocação de uma conferência de revisão será decidida pela Assembléia.

3) Qualquer organização intergovernamental nomeada como Administração encarregada da pesquisa internacional ou como Administração encarregada do exame preliminar internacional será admitida a qualquer conferência de revisão na quantidade de observadora.

4) Os artigos 53.5), 9) e 11), 54, 55.4) a 8), 56 e 57 poderão ser modificados quer por uma conferência de revisão, quer de acordo com as disposições do artigo 61.

\section{Artigo 61}

Modificações de certas disposições do Tratado

1)a) Propostas de modificação dos artigos 53.5), 9) e 11), 54, 55.4) a 8), 56 e 57 poderão ser apresentadas por qualquer Estado membro da Assembléia, pelo Comitê Executivo ou pelo DiretorGeral.

b) Essas propostas serão comunicadas pelo Diretor-Geral aos Estados contratantes, pelo menos seis meses antes de serem submetidas ao exame da Assembléia. 
2)a) Qualquer modificação dos artigos a que se refere o parágrafo 1), será adotada pela Assembléia.

b) A adoção requirirá três quartos dos votos expressos.

3)a) Qualquer modificação dos artigos a que se refere o parágrafo 1) entrará em vigor um mês depois de recebidas pelo Diretor-Geral as notificações por escrito de aceitação, decidida de acordo com os respectivos regulamentos constitucionais, por parte de três quartos dos Estados que eram membros da Assembléia na ocasião em que a modificação foi adotada.

b) Qualquer modificação desses artigos assim aceita obriga todos os Estados que forem membros da Assembléia na ocasião em que a modificação entrar em vigor, ficando entendido que qualquer modificação que aumente as obrigações financeiras dos Estados contratantes não obriga senão aqueles dentre eles que comunicaram sua aceitação da dita modificação.

c) Qualquer modificação aceita de acordo com a alínea $a$ ) obriga todos os Estados que se tornarem membros da Assembléia depois da data em que a modificação entrou em vigor, de acordo com a alínea $a$ ).

\section{CAPÍTULO VIII}

Disposições Finais

\section{Artigo 62}

Modalidades segundo as quais os Estados poderão participar do Tratado

1) Qualquer Estado membro da União Internacional para Proteção da Propriedade Industrial poderá participar do presente Tratado por meio de:

I) Sua assinatura seguida do depósito de um instrumento de ratificação, ou

II) O depósito de um instrumento de adesão.

2) Os instrumentos de ratificação ou adesão serão depositados junto ao Diretor-Geral.

3) As disposições do artigo 24 do Ato de Estocolmo da Convenção de Paris para Proteção da Propriedade Industrial aplicar-se-ão ao presente Tratado.

4) O parágrafo 3) não poderá, em caso algum, ser interpretado como implicando o reconhecimento ou a aceitação tácita por qualquer dos Estados contratantes da situação de fato de qualquer território ao qual o presente Tratado se tenha tornado aplicável por um outro Estado contratante em virtude do citado parágrafo.

\section{Artigo 63}

Entrada em vigor do Tratado

1)a) Ressalvadas as disposições do parágrafo 3), o presente Tratado entrará em vigor três meses depois que oito Estados hajam depositado seus instrumentos de ratificação ou de adesão, contanto, porém, que pelo menos quatro desses Estados preencham uma das condições seguintes:

I) o número dos pedidos depositados no Estado em causa seja superior a quarenta mil, de acordo com as estatísticas anuais mais recentes publicadas pelo Escritório Internacional;

II) os nacionais do Estado em causa ou as pessoas nele domiciliadas, conforme as estatísticas anuais mais recentes publicadas pelo Escritório Internacional, hajam depositado em um país estrangeiro, pelo menos mil pedidos; 
III) a Repartição nacional do Estado em causa haja recebido de nacionais de países estrangeiros ou de pessoas domiciliadas em tais países, conforme as estatísticas anuais mais recentes publicadas pelo escritório Internacional, pelo menos dez mil pedidos.

b) Para os fins desta alínea, a expressão <<pedidos>> não engloba os pedidos de modelos de utilidade.

2) Ressalvado o parágrafo 3), qualquer Estado que não participar deste Tratado na ocasião da entrada em vigor como o preceitua o parágrafo 1) estará obrigado por este Tratado três meses depois da data em que ele houve depositado seu instrumento de ratificação ou de adesão.

3) As disposições do Capítulo II e das regras correspondentes do Regulamento de execução anexo ao presente Tratado não são todavia aplicáveis senão na data em que três Estados que hajam preenchido pelo menos uma das condições enumeradas no parágrafo 1) tenham se tornado participantes deste Tratado, sem declarar, em obediência ao artigo 64.1), que não se consideram obrigados pelas disposições do Capítulo II. Essa data entretanto não poderá ser anterior à da entrada em vigor inicial, de acordo com o parágrafo 1).

\section{Artigo 64}

Ressalvas

1)a) Qualquer Estado poderá declarar não se considerar obrigado pelas disposições do Capítulo II.

b) Os Estados que fizerem uma declaração segundo a alínea $a$ ), não serão obrigados pelas disposições do Capítulo II e pelas disposições correspondentes do Regulamento de execução.

2)a) Qualquer Estado que não houver feito uma declaração segundo o parágrafo 1)a) poderá declarar que:

I) não está obrigado pelas disposições do artigo 39.1) relativo à remessa de uma cópia do pedido internacional e de uma tradução (tal como é prescrita) deste último;

II) a obrigação de suspender o processo nacional a que se refere o artigo 40 não impede a publicação, por sua Repartição nacional ou por intermédio desta última, do pedido internacional ou de uma tradução do mesmo, ficando, entretanto, entendido que esse Estado não estará dispensado das obrigações previstas nos artigos 30 e 38.

b) Os Estados que fizerem uma tal declaração não ficam obrigados senão em conseqüência da mesma.

3)a) Qualquer Estado poderá declarar que, no que lhe diz respeito, a publicação internacional de pedidos internacionais não é obrigatória.

b) Quando, depois de expirado um prazo de dezoito meses contados da data de prioridade, o pedido internacional não contiver senão a designação de Estados que fizeram declarações de acordo com a alínea $a$ ), o pedido internacional não será publicado conforme o artigo 21.2).

c) No caso de aplicação das disposições da alínea $b$ ), o pedido internacional será, entretanto, publicado pelo Escritório Internacional:

I) a pedido do depositante: de acordo com o Regulamento de execução;

II) quando um pedido nacional ou uma patente baseada no pedido internacional forem publicados pela Repartição nacional de todo Estado designado que tenha feito uma declaração de acordo com a alínea $a$ ) ou em nome dessa Repartição, dentro de breve prazo depois dessa publicação, nunca porém antes de dezoito meses depois da data de prioridade.

4)a) Qualquer Estado cuja legislação nacional reconheça a suas patentes qualquer efeito sobre o estado da técnica a contar de uma data anterior à da publicação, mas não assimile, para os fins do estado da técnica, a data de prioridade reivindicada de acordo com a Convenção de Paris para Proteção da Propriedade Industrial na data do depósito efetivo nesse Estado, poderá declarar que o 
depósito, fora de seu território, de um pedido internacional que o designe não será assimilado a um depósito efetivo em seu território para fins do estado da técnica.

b) Qualquer Estado que tenha feito a declaração a que se refere a alínea $a$ ) não será, dentro deste limite, obrigado pelo artigo 11.3).

c) Qualquer Estado que tenha feito a declaração mencionada na alínea a) deverá, ao mesmo tempo, declarar por escrito a data a partir da qual e as condições em que o efeito sobre o estado da técnica de qualquer pedido internacional que o designe se produzirá em seu território. Essa declaração poderá ser modificada a qualquer época por notificação endereçada ao Diretor- Geral.

5) Qualquer Estado poderá declarar que não se considera obrigado pelo artigo 59. No que diz respeito a qualquer divergência entre um Estado contratante que tenha feito uma tal declaração e qualquer outro Estado contratante, não serão aplicáveis as disposições do artigo 59.

6)a) Qualquer declaração feita de acordo com o presente artigo deverá ser por escrito. Poderá ser feita à época da assinatura do presente Tratado, na ocasião do depósito do instrumento de ratificação ou de adesão, ou, salvo no caso sobre o qual dispõe o parágrafo 5), posteriormente, a qualquer época, através de notificação endereçada ao Diretor-Geral. No caso da citada notificação, a declaração produzirá efeito seis meses após a data do recebimento da notificação pelo DiretorGeral e não afetará os pedidos internacionais depositados antes de expirado esse período de seis meses.

b) Qualquer declaração feita de acordo com o presente artigo poderá ser retirada a qualquer época por notificação endereçada ao Diretor-Geral. Tal retirada tornar-se-á efetiva três meses depois da data do recebimento da notificação pelo Diretor-Geral e, quando se tratar da retirada de uma declaração segundo o dispõe o parágrafo 3), não afetará os pedidos internacionais depositados antes da expiração do prazo de três meses.

7) Nenhuma ressalva, além das autorizadas nos parágrafos 1) a 5), será admitida pelo presente Tratado.

\section{Artigo 65}

\section{Aplicação progressiva}

1) Se o acordo concluído com uma Administração encarregada da pesquisa internacional ou do exame preliminar internacional estipular, em caráter transitório, um limite do número ou do tipo de pedidos internacionais que essa Administração se comprometerá a processar, a Assembléia tomará as medidas necessárias à aplicação progressiva do presente Tratado e do Regulamento de execução a determinadas categorias de pedidos internacionais. Essa disposição aplica-se também aos pedidos de pesquisa de tipo internacional, de acordo com o artigo 15.5).

2) A Assembléia fixará as datas a partir das quais, ressalvado o parágrafo 1), o pedidos internacionais poderão ser depositados e os pedidos de exame preliminar internacional poderão ser apresentados. Essas datas não poderão ser posteriores ao sexto mês seguinte, segundo o caso, à entrada em vigor do presente Tratado, de acordo com as disposições do artigo 63.1), ou à aplicação do Capítulo II de acordo com o artigo 63.3).

\section{Artigo 66}

\section{Denúncia}

1) Qualquer Estado contratante poderá denunciar o presente Tratado, por notificação endereçada ao Diretor-Geral.

2) A denúncia terá efeito seis meses depois da data do recebimento da notificação pelo DiretorGeral. Essa denúncia não alterará os efeitos do pedido internacional no Estado que fizer a denúncia, se for feita antes de expirado o período de seis meses, em que foi feito o depósito do pedido e em que, se o Estado em causa foi feito eleito, a eleição foi efetuada. 


\section{Artigo 67}

Assinatura e línguas

1)a) O presente Tratado é assinado em uma única via original nas línguas francesa e inglesa, tendo os textos igual valor.

b) Textos oficiais serão determinados pelo Diretor-Geral depois de consultados os governos interessados, nas línguas alemã, espanhola, japonesa, portuguesa e russa, e nas outras línguas que a Assembléia venha a recomendar.

2) O presente Tratado estará à disposição para assinaturas até 31 de Dezembro de 1970.

\section{Artigo 68}

Funções do depositário

1) A via original do presente Tratado, quando não estiver mais à disposição de assinaturas, será depositada junto ao Diretor-Geral.

2) O Diretor-Geral certificará o presente Tratado e transmitirá duas cópias do mesmo e do Regulamento de execução que lhe vai anexo aos governos de todos os Estados participantes da Convenção de Paris para Proteção da Propriedade Industrial e, a pedido, ao governo de qualquer outro Estado.

3) O Diretor-Geral mandará registrar o presente Tratado no Secretariado da Organização das Nações Unidas.

4) O Diretor-Geral certificará qualquer modificação do presente Tratado e do Regulamento de execução e transmitirá duas cópias das mesmas aos governos de todos os Estados contratantes e, a pedido, ao governo de qualquer outro Estado.

\section{Artigo 69}

\section{Notificações}

O Diretor-Geral notificará aos governos de todos os Estados participantes da Convenção de Paris para Proteção da propriedade Industrial:

I) as assinaturas apostas de acordo com o artigo 62;

II) o depósito dos instrumentos de ratificação ou de adesão acordo com o artigo 62;

III) a data da entrada em vigor do presente Tratado e a data a partir da qual o Capítulo II será aplicável de acordo com o artigo 63.3);

IV) as declarações feitas em virtude do artigo 64.1) a 5);

V) as retiradas feitas em virtude do artigo 64.6)b);

VI) as denúncias recebidas em obediência ao artigo 66;

VII) as declarações feitas em virtude do artigo 31.4).

\section{Regulamento de Execução do Tratado de Cooperação em Matéria de Patentes}

Índice Das Regras*

Parte A: Regras Introdutórias

Regra 1: Expressões abreviadas

Regra 2: Interpretação de certas palavras

Parte B: Regras Relativas ao Capítulo I do Tratado 
Regra 3: Requerimento (formulário)

Regra 4: Requerimento (conteúdo)

Regra 5: Descrição

Regra 6: Reivindicações

Regra 7: Desenhos

Regra 8: Resumo

Regra 9: Expressões, etc., que não deverão ser utilizadas

Regra 10: Terminologia e sinais

Regra 11: Condições materiais do pedido internacional

Regra 12: Língua do pedido internacional

Regra 13: Unidades da invenção

Regra 14: Taxa de transmissão

Regra 15: Taxa internacional

Regra 16: Taxa de pesquisa

Regra 17: Documento de prioridade

Regra 18: Depositante

Regra 19: Repartição receptora competente

Regra 20: Recebimento do pedido internacional

Regra 21: Preparo de cópias

Regra 22: Transmissão da via original

Regra 23: Transmissão de cópias de pesquisa

Regra 24: Recebimento da via original pelo Escritório Internacional

Regra 25: Recebimento da cópia de pesquisa pela Administração encarregada da pesquisa internacional

Regra 26: Controle e correção de certos elementos do pedido internacional

Regra 27: Falta de pagamento de taxas

Regra 28: Falhas notadas pelo Escritório Internacional ou pela Administração encarregada da pesquisa internacional

Regra 29: Pedidos internacionais ou designações considerados como retirados no sentido do artigo 14.1), 3) ou 4)

* Este índice é incluído a fim de facilitar a consulta do texto. O original não possui um índice.

Regra 30: Prazo a que se refere o artigo 14.4)

Regra 31: Cópias a que se refere o artigo 13

Regra 32: Retirada do pedido internacional ou de designações

Regra 33: Estado da técnica pertinente para fins da pesquisa internacional

Regra 34: Documentação mínima 
Regra 35: Administração competente encarregada da pesquisa internacional

Regra 36: Exigências mínimas para as Administrações encarregadas de pesquisa internacional

Regra 37: Título omisso ou defeituoso

Regra 38: Resumo omisso ou defeituoso

Regra 39: Matéria a que se refere o artigo 17.2)a)I)

Regra 40: Falta de unidade da invenção (pesquisa internacional)

Regra 41: Pesquisa de tipo internacional

Regra 42: Prazo para a pesquisa internacional

Regra 43: Relatório de pesquisa internacional

Regra 44: Transmissão do relatório de pesquisa internacional, etc.

Regra 45: Tradução do relatório de pesquisa internacional

Regra 46: Emenda das reivindicações junto ao Escritório Internacional

Regra 47: Comunicação às Repartições designadas

Regra 48: Publicação internacional

Regra 49: Línguas das traduções e montante das taxas conforme o artigo 22.1) e 2)

Regra 50: Faculdade a que se refere o artigo 22.3)

Regra 51: Revisão por Repartições designadas

Regra 52: Emenda das reivindicações, da descrição e dos desenhos junto às Repartições designadas

Parte C: Regras Relativas ao Capítulo II do Tratado

Regra 53: Pedido de exame preliminar internacional

Regra 54: Depositante autorisado a apresentar um pedido de exame preliminar internacional

Regra 55: Línguas (exame preliminar internacional)

Regra 56: Eleições ulteriores

Regra 57: Taxa de execução

Regra 58: Taxa de exame preliminar

Regra 59: Administração competente encarregada do exame preliminar internacional

Regra 60: Certas falhas no pedido de exame preliminar internacional ou nas eleições

Regra 61: Notificação do pedido de exame preliminar internacional e das eleições

Regra 62: Cópia para a Administração encarregada do exame preliminar internacional

Regra 63: Exigências mínimas para as Administrações encarregadas do exame preliminar internacional

Regra 64: Estado da técnica para efeito do exame preliminar internacional

Regra 65: Atividade inventiva ou não-evidência

Regra 66: Processamento na Administração encarregada do exame preliminar internacional

Regra 67: Matéria a que se refere o artigo 34.4)a)I) 
Regra 68: Falta de unidade da invenção (exame preliminar internacional)

Regra 69: Prazo para o exame preliminar internacional

Regra 70: Relatório de exame preliminar internacional

Regra 71: Transmissão do relatório de exame preliminar internacional

Regra 72: Tradução do relatório de exame preliminar internacional

Regra 73: Comunicação do relatório de exame preliminar internacional

Regra 74: Tradução e transmissão dos anexos ao relatório de exame preliminar internacional

Regra 75: Retirada do pedido internacional, do pedido de exame preliminar internacional ou de eleições

Regra 76: Línguas das traduções e montantes das taxas de acordo com o artigo 39.1); Tradução do documento de prioridade

Regra 77: Faculdade a que se refere o artigo 39.1)b)

Regra 78: Emenda das reivindicações, da descrições e dos desenhos junto às Repartições eleitas

Parte D: Regras Relativas ao Capítulo III do Tratado

Regra 79: Calendário

Regra 80: Cálculo dos prazos

Regra 81: Modificação dos prazos fixados pelo Tratado

Regra 82: Irregularidades no serviço postal

Regra 83: Direito de exercer junto a Administrações internacionais

Parte E: Regras Relativas ao Capítulo V do Tratado

Regra 84: Despesas das delegações

Regra 85: Falta de quorum na Assembléia

Regra 86: Gazeta

Regra 87: Cópias de publicações

Regra 88: Modificação do Regulamento de execução

Regra 89: Instruções Administrativas

Parte F: Regras Relativas a Vários Capítulos do Tratado

Regra 90: Representação

Regra 91: Erros evidentes de transcrição

Regra 92: Correspondência

Regra 93: Processos e registros

Regra 94: Remessa de cópias pelo Escritório Internacional e pela Administração encarregada do exame preliminar internacional

Regra 95: Disponibilidade de traduções 


\section{PARTE A}

\section{Regras Introdutórias}

Regra 1

Expressões abreviadas

\subsection{Sentido das Expressões Abreviadas}

a) No sentido que lhe empresta o presente Regulamento de execução, deve-se entender por $<<$ Tratado $>>$ o Tratado de Cooperação em Matéria de Patentes.

b) No sentido que lhe empresta o presente Regulamento de execução, as expressões $<<$ Capítulo $>>$ e $<<$ artigo $>>$ significam o capítulo ou o artigo indicado do Tratado.

Regra 2

Interpretação de certas palavras

$2.1<<$ Depositante $>>$

Toda vez que a palavra $<<$ depositante $>>$ for utilizada, deverá ser compreendida como significando igualmente o mandatário ou outro representante do depositante, a menos que o contrário decorra claramente do teor ou da natureza da disposição ou do contexto em que tal palavra é utilizada, como é o caso, particularmente, quando a disposição se refere ao domicílio ou à nacionalidade do depositante.

\section{$2.2<<$ Mandatário $>>$}

Toda vez que a palavra $<<$ mandatário $>>$ for utilizada, deverá ser compreendida como significando toda pessoa autorizada a exercer, junto às administrações internacionais, da maneira definida pelo artigo 49; a menos que o contrário decorra claramente do teor ou da natureza da disposição ou do contexto em que tal palavra é utilizada, ela deverá ser compreendida como significando igualmente, o representante comum mencionado na regra 4.8.

\section{$2.3<<$ Assinatura $>>$}

Toda vez que a palavra <<assinatura $>>$ for utilizada, deverá ficar compreendido que se a legislação nacional da Repartição receptora ou da Administração competente encarregada da pesquisa internacional ou do exame preliminar internacional exigir a utilização de um selo em lugar da assinatura, a palavra $<<$ assinatura $>>$ significa $<<$ selo $>>$ para todos os fins dessa Repartição ou Administração.

\section{PARTE B}

\section{Regras Relativas ao Capítulo I do Tratado}

\section{Regra 3}

Requerimento (formulário)

\subsection{Formulário impresso}

O requerimento deverá ser feito em um formulário impresso.

\subsection{Disponibilidade de formulários}

Exemplares de formulários impressos serão fornecidos gratuitamente aos depositantes pelas Repartições receptoras ou se estas assim o desejarem pelo Escritório Internacional. 


\subsection{Lista de controle}

a) O formulário impresso conterá uma lista de controle que, uma vez preenchida, revelará:

I) o número total de folhas que constituem o pedido internacional e o número das folhas de cada elemento desse pedido (requerimento, descrição, reivindicações, desenhos, resumo);

II) se ao pedido internacional, tal como foi depositado, foram juntado ou não uma procuração (isto é, um documento nomeando um mandatário ou um representante comum), um documento de prioridade, um recibo relativo a taxas pagas ou um cheque para pagamento de taxas, um relatório de pesquisa internacional ou um relatório de pesquisa do tipo internacional, um documento tendo por objeto provar que o depositante tem os direitos do inventor, assim como qualquer outro documento (a ser especificado na lista de controle);

III) o número da ilustração dos desenhos que o depositante propõe que acompanhe o resumo quando este for publicado na página de cobertura da brochura e na Gazeta; em casos excepcionais o depositante poderá propor a publicação de mais de uma ilustração.

b) A lista controle deverá ser preenchida pelo depositante, mas caso deixe de fazê-lo, a Repartição receptora a preencherá, ela própria, fazendo as anotações cabíveis; entretanto a Repartição receptora não inscreverá o número mencionado na alínea $a$ )III).

\subsection{Detalhes}

Sob ressalva da regra 3.3, os detalhes do formulário impresso serão prescritos pelas Instruções Administrativas.

\section{Regra 4}

Requerimento (conteúdo)

4.1 Conteúdo obrigatório e conteúdo facultativo: Assinatura

a) O requerimento deverá conter:

I) uma petição;

II) o título da invenção;

III) indicações relativas a depositante e, quando for o caso, ao mandatário;

IV) a designação de Estados;

V) indicações a respeito do inventor, quando a legislação nacional de pelo menos um Estado designado determinar que o nome do inventor seja fornecido ao ser depositado um pedido nacional.

b) O requerimento deverá conter quando for o caso:

I) uma reivindicação de prioridade;

II) uma referência a uma pesquisa internacional anterior ou a qualquer pesquisa anterior de tipo internacional;

III) uma seleção de certos tipos de proteção;

IV) indicação de que o depositante deseja obter uma patente regional e o nome dos Estados designados para os quais deseja obter uma tal patente;

V) uma referência a um pedido principal ou a uma patente principal.

c) O requerimento poderá conter indicações a respeito do inventor desde que a legislação nacional de nenhum Estado designado determine que o nome do inventor seja fornecido na ocasião do depósito de um pedido nacional.

d) O requerimento deverá ser assinado. 


\subsection{Petição}

A petição deverá ser do teor e redigida de preferência como a seguir:

"O abaixo assinado solicita que o presente pedido internacional seja processado de acordo com o Tratado de Cooperação em Matéria de Patentes."

\subsection{Título da invenção}

O título da invenção deverá ser breve (conter de preferência de duas a sete palavras quando for elaborado em, ou traduzido para o inglês) e preciso.

\subsection{Nomes e endereços}

a) Os nomes das pessoas físicas deverão ser indicados pelos seus nomes e sobrenomes, estes últimos precedendo os primeiros.

b) Os nomes das pessoas jurídicas deverão ser indicados por suas designações oficiais completas.

c) Os endereços deverão ser indicados de acordo com as exigências usuais tendo em vista uma rápida entrega postal no endereço indicado e deverão sempre conter todas as unidades administrativas pertinentes, inclusive o número do prédio, caso exista um. Caso a legislação nacional do Estado designado não exija a indicação do número do prédio, o fato de não ser indicado esse número não terá efeito nesse Estado. É aconselhável mencionar o endereço telegráfico e de telex e o número de telefone quando os houver.

d) Apenas um endereço será necessário em relação a cada depositante, inventor ou mandatário.

\subsection{Depositante}

a) O requerimento deverá indicar o nome, o endereço, a nacionalidade e o domicílio do depositante ou, se houver vários depositantes, de cada um deles.

b) A nacionalidade do depositante deverá ser indicada pelo nome do Estado de que for natural.

c) O domicílio do depositante deverá ser indicado pelo nome do Estado em que tiver seu domicílio.

\subsection{Inventor}

a) Nos casos estipulados pela regra $4.1 \mathrm{a}) \mathrm{V}$ ) o requerimento deverá indicar o nome e o endereço do inventor ou, caso haja vários inventores, de cada um deles.

b) Se o depositante for o inventor, em lugar da indicação mencionada na alínea $a$ ), o requerimento deverá conter uma declaração a esse respeito ou repetir o nome do depositante no espaço reservado à indicação do inventor.

c) Em relação a Estados designados diferentes, o requerimento poderá indicar pessoas diferentes, como inventores, quando as exigências das legislações nacionais desses Estados divergirem a esse respeito. Nesse caso, o requerimento deverá conter uma declaração separada para cada Estado designado ou para cada grupo de Estados designados em que uma determinada pessoa ou a mesma pessoa, deva ser considerada como sendo o inventor, ou ainda em que determinadas pessoas, ou as mesmas pessoas, devam ser consideradas como os inventores.

\subsection{Mandatário}

Se houver designação de mandatários, o requerimento deverá declará-lo e indicar o nome e o endereço dos mesmos.

4.8 Representação de vários depositantes sem mandatário comum

a) Se houver mais de um depositante e se o requerimento não indicar um mandatário como representante de todos os depositantes ("mandatário comum"), o requerimento deverá designar 
como representante comum a todos os depositantes, um dos depositantes autorizado a depositar um pedido internacional de acordo com o artigo 9.

b) Se houver mais de um depositante e se o requerimento não indicar um mandatário para representar todos os depositantes e não designar um dos depositantes, de acordo com a alínea $a$ ), o depositante mencionado em primeiro lugar no requerimento como autorizado a depositar um pedido internacional, de acordo com o artigo 9, será considerado como o representante comum.

\subsection{Designação de Estados}

Os Estados contratantes deverão ser designados pelos seus nomes, no requerimento.

\subsection{Reivindicação de Prioridade}

a) A declaração mencionada no artigo 8.1) deverá ser feita no requerimento; consiste em uma declaração de reivindicação da prioridade de um pedido anterior e deverá indicar:

I) quando o pedido anterior não for um pedido regional ou internacional, o nome do país em que foi depositado; quando o pedido for um pedido regional ou internacional, o nome do país ou dos países para os quais houver sido depositado;

II) a data em que foi depositada;

III) o número do depósito; e

IV) quando o pedido anterior for um pedido regional ou internacional, a Repartição receptora ou a organização intergovernamental em que foi depositado.

b) Se o requerimento não indicar ao mesmo tempo:

I) o nome do país em que o pedido anterior foi depositado, quando este último não for um pedido regional ou internacional ou, for um pedido regional ou internacional, o nome de pelo menos um país em que foi depositado, e

II) a data do depósito, a reivindicação de prioridade, para os fins do processo, tal como estipulado pelo Tratado, será considerada como não havendo sido apresentada.

c) Se o número do pedido anterior não estiver indicado no pedido mas for comunicado pelo depositante ao Escritório Internacional antes de expirados 16 meses contados a partir da data de prioridade, esse número será considerado por todos os Estados designados como tendo sido comunicado em tempo hábil. Se for comunicado depois de expirado esse prazo, o Escritório Internacional informará ao depositante e às Repartições designadas a data em que esse número lhe foi comunicado. O Escritório Internacional indicará essa data na publicação internacional do pedido internacional ou, se esse número não lhe houver sido comunicado até a data dessa publicação, indicará tal fato na publicação internacional.

d) Se a data do depósito do pedido anterior, tal como consta do requerimento, for mais de um ano anterior à data do depósito internacional, a Repartição receptora ou, na falta desta, o Escritório Internacional solicitará ao depositante à requerer que o cancelamento da declaração apresentada em obediência ao artigo 8.1), quer, caso a data do pedido anterior haja sido indicada de forma errônea, a correção da data assim indicada. Se o depositante deixar de assim proceder dentro do prazo de um mês a contar da data da solicitação, a declaração feita em virtude da disposição do artigo 8.1) será cancelada ex-ofício. A Repartição receptora que efetuar a correção ou o cancelamento, disso notificará o depositante e, se já houverem sido remetidas cópias do pedido internacional para o Escritório Internacional e à Administração encarregada da pesquisa internacional, tal notificação será também feita ao dito Escritório e à dita Administração. Caso a correção ou o cancelamento seja feito pelo Escritório Internacional, este notificará de acordo ao depositante e à Administração encarregada da pesquisa internacional.

e) No caso de reivindicações de prioridade de vários pedidos anteriores, as alíneas a) a $d$ ) aplicarse-ão a cada um deles. 
4.11 Referência a uma pesquisa internacional anterior ou a uma pesquisa anterior de tipo internacional.

Se uma pesquisa internacional ou uma pesquisa de tipo internacional houver sido solicitada com base em um pedido nacional, de acordo com o artigo 15.5), o requerimento poderá indicar esse fato e identificar o pedido (ou sua tradução, conforme o caso), indicando seu país, sua data e seu número, e identificar esse pedido de pesquisa indicando sua data e, caso disponível, o seu número.

4.12 Seleção de certos tipos de proteção

a) Se o depositante desejar que o seu pedido internacional seja processado em qualquer Estado designado, não como um pedido de patente mas como um pedido de concessão de qualquer um dos demais tipos de proteção especificados no artigo 43, assim deverá especificar no requerimento. Para os fins desta alínea, o artigo 2.II) não será aplicável.

b) No caso previsto no artigo 44, o depositante deverá indicar os dois tipos de proteção desejados ou se for o caso, o tipo de proteção requerido em primeiro lugar e o requerido como subsidiário.

4.13 Identificação do pedido principal ou da patente principal

Se o depositante desejar que seu pedido internacional seja processado em qualquer Estado designado, como um pedido de patente ou certificado de adição, um certificado de autor de invenção adicional, ou um certificado de utilidade adicional, deverá identificar o pedido principal, a patente principal, o certificado de autor de invenção principal ou o certificado de utilidade principal ao qual, caso seja concedido, se referirá a patente ou o certificado de adição, o certificado de autor de invenção adicional ou o certificado de utilidade adicional. Para os fins da presente alínea, o artigo 2.II) não será aplicável.

\subsection{4 "Continuation" ou "Continuation in part"}

Se o depositante desejar que seu pedido internacional seja processado, em qualquer Estado designado, como um pedido de "Continuation" ou "Continuation in part" de um pedido anterior, deverá declará-lo no requerimento e identificar o pedido principal em causa.

\subsection{Assinatura}

O requerimento deverá ser assinado pelo depositante.

4.16 Transliteração ou tradução de certas palavras

a) Sempre que um nome ou um endereço não forem escritos em caracteres latinos, deverão ser igualmente reproduzidos, quer por transliteração, quer por tradução em inglês, em caracteres latinos. Caberá ao depositante decidir que palavras serão meramente transliteradas e quais as que serão traduzidas.

b) O nome de qualquer país que não for escrito em caracteres latinos, deverá ser também escrito em inglês.

4.17 Exclusão de indicações adicionais

a) O requerimento não deverá incluir qualquer indicação além daquelas especificadas nas regras 4.1 a 4.16 .

b) Se o requerimento contiver indicações além daquelas especificadas nas regras 4.1 a 4.16, a Repartição receptora suprimirá ex-ofício as indicações adicionais. 


\section{Regra 5}

Descrição

\subsection{Maneira de redigir a descrição}

a) A descrição deverá inicialmente indicar o título da invenção tal como consta no requerimento, além de:

I) precisar o ramo técnico a que se refere a invenção;

II) indicar a técnica anterior que, no entender do depositante, possa ser considerada útil à compreensão, à pesquisa e ao exame da invenção e, de preferência, citar os documentos que reflitam a técnica anterior;

III) divulgar a invenção, tal como foi reivindicada, em termos que permitam a compreensão do problema técnico (mesmo que este não seja expressamente designado como tal) e de sua solução, e expor os efeitos vantajosos da invenção, caso os haja, em relação à técnica anterior;

IV) descrever brevemente as ilustrações contidas nos desenhos, caso as haja;

V) expor pelo menos a melhor maneira considerada pelo depositante de executar a invenção reivindicada; isto deverá ser feito por meio de exemplos, quando forem adequados, e de referências aos desenhos, quando os houver; caso a legislação nacional do Estado designado não exija uma exposição da melhor maneira de executar a invenção, mas se contente com a descrição de uma maneira qualquer de executá-la (seja essa maneira a melhor ou não que se possa considerar), o fato de não expor a melhor maneira considerada não terá efeito nesse Estado;

VI) indicar de maneira explícita, quando não resultar evidente da descrição ou da natureza da invenção, a maneira pela qual a invenção poderá ser explorada, produzida e utilizada pela indústria ou, se poder ser apenas utilizada, a maneira pela qual poderá sê-lo; a expressão "indústria" deverá ser considerada em seu sentido mais lato, como na Convenção de Paris para Proteção da Propriedade Industrial.

b) Caso a legislação nacional do Estado designado não exija que as reivindicações sejam redigidas da forma prevista na alínea $b$ ), o fato não estarem as reivindicações redigidas dessa maneira não terá efeito nesse Estado, desde que as reivindicações hajam sido redigidas de maneira conforme à legislação nacional desse Estado.

c) A maneira e a ordem especificadas na alínea $a$ ) deverão ser obedecidas a não ser que, em virtude da natureza da invenção, outra maneira e outra ordem diversas facultem melhor compreensão e uma apresentação mais econômica.

d) Ressalvada a alínea $b$ ) cada um dos elementos a que se refere a alínea $a$ ) deverá ser de preferência precedido por um título apropriado, de acordo com as recomendações constantes das Instruções Administrativas.

Regra 6

Reivindicações

6.1 Número e numeração das reivindicações

a) O número das reivindicações deverá ser razoável, levando-se em conta a natureza da invenção reivindicada.

b) Caso haja várias reivindicações, estas deverão ser numeradas consecutivamente em algarismos árabes.

c) O sistema de numeração, no caso de emenda das reivindicações, será especificado nas Instruções Administrativas. 


\subsection{Referências a outras partes do pedido internacional}

a) Exceto quando, absolutamente necessário, as reivindicações não se deverão basear, no que diz respeito às características técnicas da invenção, em referências à descrição ou aos desenhos. Não se deverão basear, particularmente, em referências tais como: "como descrito na parte ... da descrição", ou "como representado pela ilustração .. dos desenhos".

b) Quando o pedido internacional contiver desenhos, as características técnicas mencionadas nas reivindicações deverão ser de preferência acompanhadas por sinais de referência pertinentes dos desenhos. Quando utilizados, os sinais de referência deverão ser preferivelmente colocados entre parênteses. Se os sinais de referências não facilitarem particularmente uma compreensão mais rápida da reivindicação, deverão ser omitidos. Os sinais de referências poderão ser retirados por uma Repartição designada, para efeito de publicação por essa Repartição.

\subsection{Maneira de redigir as reivindicações}

a) A definição da matéria para a qual é solicitada a proteção deverá ser feita em termos de características técnicas da invenção.

b) Sempre que for conveniente, as reivindicações deverão conter:

I) uma declaração indicando as características técnicas da invenção necessárias à definição da matéria reivindicada, mas que, em combinação, constituam parte do estado da técnica;

II) uma parte caracterizante - precedida pelas palavras "caracterizado em", "caracterizado por", ou "o aperfeiçoamento compreende", ou quaisquer outras palavras no mesmo teor - expondo de forma concisa as características técnicas que, juntamente com as características mencionadas em I), se desejar proteger.

\subsection{Reivindicações dependentes}

a) Qualquer reivindicação que compreenda todas as características de uma ou de várias reivindicações (reivindicação de forma dependente, daqui por diante chamada de "reivindicação dependente") deverá conter uma referência, de preferência no princípio, a essa outra reivindicação ou a essas outras reivindicações, quando então deverá especificar as características adicionais reivindicadas. Qualquer reivindicação dependente que se referir a mais de uma outra reivindicação ("reivindicação dependente múltipla") só se referirá a essas reivindicações como uma alternativa. Reivindicações dependentes múltiplas não deverão servir de base a qualquer outra reivindicação dependente múltipla.

b) Qualquer reivindicação dependente deverá ser compreendida como incluindo todas as limitações contidas na reivindicação à qual ela se refere ou caso a reivindicação dependente seja uma reivindicação dependente múltipla, todas as limitações contidas na reivindicação particular a que ela se refere.

c) Todas as reivindicações dependentes que se referirem a uma reivindicação anterior única e todas as reivindicações dependentes que se referirem a várias reivindicações anteriores deverão ser agrupadas tanto quanto, e de maneira mais prática possível.

\subsection{Modelos de Utilidade}

Qualquer Estado designado em que a concessão de um modelo de utilidade for requerida por um pedido internacional poderá aplicar, em lugar das regras 6.1 a 6.4, em relação aos assuntos a que estes se referem, as disposições de sua legislação nacional no que diz respeito a modelos de utilidade e assim que o processo do pedido internacional houver sido iniciado nesse Estado, desde que ao requerente seja concedido um prazo de pelo menos 2 meses a contar da expiração do prazo estipulado pelo artigo 22 para que adapte seu pedido às exigências das referidas disposições da legislação nacional. 


\section{Regra 7}

Desenhos

7.1 Gráficos das operações e diagramas

Os gráficos das operações e os diagramas serão considerados como desenhos.

\section{2 prazo}

O prazo mencionado no artigo 7.2)II) deverá ser razoável levando-se em conta as circunstâncias do caso em espécie, não devendo nunca ser inferior a dois meses contados a partir da data do convite escrito a proceder ao depósito de desenhos ou desenhos adicionais, em obediência à disposição em questão.

\section{Regra 8}

Resumo

\subsection{Conteúdo e forma de resumo}

a) O resumo deverá compreender:

I) um sumário da exposição tal como consta da descrição, das reivindicações e de todos os desenhos; o sumário deverá indicar o ramo técnico ao qual pertence a invenção e deverá ser redigido de forma a permitir uma compreensão clara do problema técnico, da essência da solução desse problema por meio da invenção e de uso principal ou dos usos principais da invenção;

II) quando for o caso, a fórmula química que, entre todas as fórmulas constantes do pedido internacional, melhor caracterise a invenção.

b) O resumo deverá ser tão conciso quanto a exposição o permitir (de preferência de 50 a 150 palavras quando for elaborado em, ou traduzido para o inglês).

c) O resumo não deverá conter declarações relativas aos méritos ou ao valor alegados da invenção reivindicada, nem as suas supostas aplicações.

d) Cada uma das principais características técnicas mencionadas no resumo e ilustradas por um desenho constante do pedido internacional deverá ser acompanhada por um sinal de referência colocado entre parênteses.

\subsection{Falta de indicação da ilustração a ser publicada com o resumo}

Se o depositante deixar de fornecer a indicação a que se refere a regra $3.3^{\mathrm{a}}$ )III) ou se a Administração encarregada da pesquisa internacional julgar que uma ilustração ou ilustrações dentre toda as ilustrações de todos os desenhos poderá caracterisar melhor a invenção do que aquela ou aquelas apresentadas pelo depositante, ela indicará qual a ilustração ou ilustrações em questão. As publicações feitas pelo Escritório Internacional utilizarão então a ilustração ou as ilustrações assim indicadas pela Administração encarregada da pesquisa internacional. Em caso contrário, a ilustração ou as ilustrações propostas pelo depositante serão utilizadas para essas publicações.

\subsection{Regras de redação}

O resumo deverá ser redigido de forma a poder servir de instrumento eficaz de pré-seleção para fins de pesquisa no determinado ramo técnico, especialmente ajudando o cientista, o engenheiro ou o pesquisador a formular uma opinião quanto à questão da conveniência ou não de consultar o próprio pedido internacional. 


\section{Regra 9}

Expressões, etc., que não deverão ser utilizadas

\subsection{Definição}

O pedido internacional não deverá conter:

I) expressões ou desenhos ofensivos a moral;

II) expressões ou desenhos contrários à ordem pública;

III) declarações depreciativas dos produtos ou processos de qualquer outra pessoa além do depositante, ou dos méritos e da validade de pedidos ou de patentes de uma tal pessoa (meras comparações com o estado da técnica não são consideradas como depreciativas em si);

IV) declarações ou outros elementos claramente irrelevantes ou desnecessários no caso.

\subsection{Anotação da falta de conformidade}

A Repartição receptora e a Administração encarregada da pesquisa internacional poderão anotar a falta de conformidade com às determinações da regra 9.1 e poderão propor ao depositante que corrija voluntariamente, de acordo, seu pedido internacional. Se a Repartição receptora houver anotado a falta de conformidade, disso informará a Administração internacional competente encarregada da pesquisa internacional e o Escritório Internacional; se a falta de conformidade for anotada pela Administração encarregada da pesquisa internacional, esta Administração informará de acordo a Repartição receptora e o Escritório Internacional.

\subsection{Referência ao artigo 21.6)}

As <<declarações depreciativas >> mencionadas no artigo 21.6) têm o sentido especificado na regra 9.1.III).

\section{Regra 10}

Terminologia e sinais

\subsection{Terminologia e sinais}

a) As unidades de pesos e medidas deverão ser expressas pelo sistema métrico ou também expressas por esse sistema caso tenham sido previamente expressas de acordo com outro sistema.

b) As temperaturas deverão ser expressas em graus centígrados, ou também expressas em graus centígrados se houverem sido previamente expressas de acordo com outro sistema.

c) A densidade deverá ser expressa em unidades métricas.

d) Em relação as indicações de calor, energia, luz, som e magnetismo, assim como em relação às fórmulas matemáticas e às unidades elétricas, deverão ser observadas as determinações da prática internacional; quanto às fórmulas químicas, deverão ser utilizados os símbolos, pesos atômicos e fórmulas moleculares geralmente em uso.

e) Em regra geral, só deverão ser utilizados termos, sinais ou símbolos técnicos geralmente aceitos no ramo.

f) Quando o pedido internacional for elaborado em, ou traduzido para o inglês ou o japonês, as frações deverão ser indicadas por um ponto; quando o pedido internacional for elaborado em, ou traduzido para outra língua além do inglês ou do japonês, as frações deverão ser indicadas por uma vírgula.

10.2 Uniformidade

A terminologia e os sinais deverão ser uniformes em todo o pedido internacional. 


\section{Regra 11}

Condições materiais do pedido internacional

a) Ressalvada a alínea $b$ ), o pedido internacional e todo e qualquer documento constante da lista de controle a que se refere a regra 3.3. a) II) deverá ser depositado em uma única via.

b) Qualquer Repartição receptora poderá exigir o pedido internacional e todo e qualquer documento constante da lista de controle (regra 3.3. a) II), exceto o recibo de taxas pagas ou do cheque destinado ao pagamento das taxas, seja depositado em duas ou três vias. Nesse caso, a Repartição receptora será responsável pela verificação da identidade da segunda e terceira cópias com a via original.

\section{Possibilidade de reprodução}

a) Todos os elementos do pedido internacional (a saber: o requerimento, a descrição, as reivindicações, os desenhos e o resumo) deverão ser apresentados de maneira a poderem ser reproduzidos diretamente por meio de fotografia, de processos eletrostáticos, do offset e da microfilmagem em um número indeterminado de cópias.

b) Nenhuma folha deverá ser amassada ou rasgada; nenhuma folha deverá ser dobrada.

c) Só deverá ser utilizado um lado de cada folha.

d) Ressalvada a regra 11.13. j), cada folha deverá ser utilizada verticalmente (quer dizer que seus lados menores deverão ficar em cima e em baixo).

\subsection{Material a ser utilizado}

Todos os elementos do pedido internacional deverão figurar em papel flexível, resistente, branco, liso, sem brilho e durável.

11.4 Folhas separadas, etc.

a) Cada elemento do pedido internacional (requerimento, descrição, reivindicações, desenhos, resumo) deverá começar em uma folha nova.

b) Todas as folhas do pedido internacional deverão ser reunidas de maneira a poderem ser facilmente viradas ao serem consultadas e de maneira a poderem ser facilmente separadas e reunidas novamente quando houver necessidade de separá-las para reprodução.

\subsection{Formato das folhas}

As folhas deverão ser de formato A4 (29,7cm X 21cm). Entretanto, qualquer Repartição receptora poderá aceitar pedidos internacionais apresentados em folhas de formato diferente, desde que a via original, tal como foi transmitida ao Escritório Internacional, e a cópia da pesquisa, se a Administração competente encarregada da pesquisa internacional o desejar, sejam de formato A4.

\subsection{Margens}

a) As margens mínimas das folhas que constituem o requerimento, a descrição, as reivindicações e o resumo deverão ser as seguintes:

alto da primeira folha, exceto a do requerimento: $8 \mathrm{~cm}$

alto das outras folhas: $2 \mathrm{~cm}$

margem esquerda: $2,5 \mathrm{~cm}$

margem direita: $2 \mathrm{~cm}$

fim de cada folha: $2 \mathrm{~cm}$ 
b) O máximo recomendado para as margens mencionadas na alínea a) é o seguinte:

alto da primeira folha, exceto a do requerimento: $9 \mathrm{~cm}$

alto das outras folhas: $4 \mathrm{~cm}$

margem esquerda: $4 \mathrm{~cm}$

margem direita: $3 \mathrm{~cm}$

fim de cada folha: $3 \mathrm{~cm}$

c) Nas folhas que contêm desenhos, a superfície utilizável não deverá exceder 26,2cm X 17,0cm. Essas folhas não deverão conter qualquer moldura em torno da superfície utilizada ou utilizável. As margens mínimas deverão ser as seguintes:

alto da folha: $2,5 \mathrm{~cm}$

margem esquerda: $2,5 \mathrm{~cm}$

margem direita: $1,5 \mathrm{~cm}$

fim da folha: $1,0 \mathrm{~cm}$

d) As margens mencionadas nas alíneas $a$ ) e $c$ ) foram previstas para folhas de formato A4; entretanto, mesmo que a Repartição receptora aceite outros formatos, a via original do formato A4 e, quando for exigida, a cópia da pesquisa de formato A4, deverão respeitar as margens acima.

e) As margens do pedido internacional, na ocasião de seu depósito, deverão estar totalmente virgens.

11.7 Numeração das folhas

a) Todas as folhas contidas no pedido internacional deverão ser numeradas consecutivamente, em algarismos árabes.

b) Os números deverão ser inscritos ao alto e no meio das folhas e não nas margens.

11.8 Numeração das linhas

a) É altamente recomendável que se numere cada quinta linha de cada folha da descrição e de cada folha de reivindicações.

b) Os números deverão aparecer no lado esquerdo, à direita da margem.

\subsection{Composição dos textos}

a) O requerimento, a descrição, as reivindicações e o resumo deverão ser datilografados ou impressos.

b) Somente os símbolos e caracteres gráficos, as fórmulas químicas ou matemáticas e certos caracteres em língua japonesa poderão, quando necessário, ser manuscritos ou desenhados.

c) Os espaços datilografados deverão ser de 11/2.

d) Todos os textos deverão ser elaborados em caracteres de 0,21 cm de altura no mínimo e deverão ser reproduzidos em côr escura e indelével e se confornar às condições estabelecidas na regra 11.2.

e) Quanto aos espaços datilografados e ao tamanho dos caracteres, as alíneas $c$ ) e $d$ ) não se aplicam aos textos elaborados em língua japonesa.

11.10 Desenhos, fórmulas e tabela constantes dos textos

a) O requerimento, a descrição, as reivindicações e o resumo não deverão conter desenhos.

b) A descrição, as reivindicações e o resumo poderão conter fórmulas químicas ou matemáticas. 
c) A descrição e o resumo poderão conter tabelas, qualquer reivindicação poderá incluir tabelas, desde que o seu assunto o torne aconselhável.

\subsection{Textos nos desenhos}

a) Os desenhos não deverão conter textos, com exceção de uma palavra ou palavras - desde que isto seja absolutamente necessário - tais como <<água $>>,<<$ vapor $>>,<<$ aberto $>>,<<$ fechado $>>$, $<<$ corte de $\mathrm{AB}>>$ e, no caso de esquemas de circuitos elétricos, de diagramas em bloco e de gráficos de operações, de algumas palavras-chave indispensáveis a sua compreensão.

b) Cada palavra utilizada deverá ser colocada de maneira que, se fôr traduzida, sua tradução possa lhe ser superposta sem cobrir uma única linha dos desenhos.

\subsection{Correções, etc.}

Nenhuma folha deverá ser apagada mais do que o razoável nem deverá conter correções, nem palavras rebatidas ou intercaladas entre as linhas. Em casos excepcionais, poderão ser autorizadas derrogações desta regra, desde que a autenticidade do conteúdo não esteja em jôgo e desde que não sejam prejudicadas as condições necessárias a uma boa reprodução.

\subsection{Prescrições especiais para os desenhos}

a) Os desenhos deverão ser executados em linhas e traços duráveis, pretos ou azuis, suficientemente densos e escuros, de espessura uniforme e bem definidos e não deverão ser coloridos.

b) Os cortes deverão ser indicados por sombras oblíquas que não impeçam que se leiam facilmente os sinais de referências e as linhas básicas.

c) A escala dos desenhos e a clareza de sua execução gráfica deverão ser tais que uma reprodução fotográfica efetuada com redução linear de dois terços permita distinguir facilmente todos os detalhes.

d) Quando, em casos excepcionais, a escala figurar em um desenho, ela deverá ser representada graficamente.

e) Todos os algarismos, letras e linhas de referências que figurem nos desenhos deverão ser simples e claros. Em associação a algarismos e letras não se deverá usar parênteses, círculos ou aspas.

f) Todas as linhas dos desenhos deverão ser normalmente traçadas com o auxílio de instrumentos de desenho técnico.

g) Cada elemento de cada ilustração deverá ser em proporção a cada um dos outros elementos da ilustração, exceto quando o uso de uma proporção diferente for indispensável à clareza da ilustração.

h) A altura dos algarismos e letras não deverá ser inferior a 0,32cm. Nos títulos dos desenhos, deverá ser utilizado o alfabeto latino e, onde usual, o grego.

i) Uma mesma folha de desenhos poderá conter várias ilustrações. Quando várias ilustrações dispostas em duas ou mais folhas formarem uma única ilustração completa, as diversas ilustrações nas várias folhas deverão ser dispostas de forma a poderem ser reunidas sem esconder qualquer parte de qualquer dessas ilustrações.

j) As diversas ilustrações deverão ser dispostas sobre uma folha ou folhas, sem desperdício de espaço, de preferência verticalmente, cada uma claramente separada das demais.

k) As diversas ilustrações deverão ser numeradas consecutivamente, em algarismos árabes, e independentemente da numeração das folhas. 
l) Sinais de referências não mencionados na descrição não deverão aparecer nos desenhos e viceversa.

m) Os mesmos elementos quando indicados por sinais de referência deverão sê-lo pelos mesmos sinais de referência em todo o pedido internacional.

n) Se os desenhos contiverem um grande número de sinais de referência, é insistentemente recomendado que seja juntada ao pedido internacional uma folha separada que enumere todos os sinais de referência e todos os elementos que os apresentem.

\subsection{Documentos anteriores}

As regras 10 e 11.1 a 11.13 aplicam-se igualmente a todos os documentos - como por exemplo: páginas corrigidas, reivindicações emendadas - apresentados depois do depósito do pedido internacional.

\subsection{Traduções}

Nenhuma Repartição designada poderá exigir que a tradução de um pedido internacional depositado junto a ela preencha condições diferentes daquelas estabelecidas para o pedido internacional tal como foi depositado.

Regra 12

Língua do pedido internacional

\subsection{Pedido internacional}

Qualquer pedido internacional deverá ser depositado na língua ou em uma das línguas mencionadas no acordo concluído entre o Escritório Internacional e a Administração encarregada da pesquisa internacional com competência para tratar desse pedido, desde que, entretanto, se esse acordo especificar várias línguas, a Repartição receptora possa determinar qual a língua ou quais as línguas dentre as especificadas em que os pedidos internacionais deverão ser depositados.

\subsection{Modificações efetuadas no pedido internacional}

Todas as modificações ocorridas no pedido internacional, tais como emendas e correções, deverão ser elaboradas na língua desse pedido (vide regra 66.5).

Regra 13

Unidade da invenção

\subsection{Exigência}

O pedido internacional não deverá comportar senão uma invenção ou uma pluralidade de invenções ligadas entre si de tal sorte que não formem senão um só conceito inventivo geral ( $<<$ exigência de unidade da invenção $>>$ )

\subsection{Reivindicações de categorias diferentes}

A regra 13.1 deverá ser compreendida como permitindo, em particular, uma ou outra das duas possibilidades seguintes:

I) além de uma reivindicação independente para um determinado produto, a inclusão no mesmo pedido internacional de uma reivindicação independente para um processo especialmente concebido para a fabricação do mencionado produto e a inclusão no mesmo pedido internacional de uma reivindicação independente para uma utilização do dito produto, ou

II) além de uma reivindicação independente para um determinado produto, a inclusão no mesmo pedido internacional de uma reivindicação independente para um aparelho ou meio especialmente concebido para a execução do dito processo. 


\subsection{Reivindicações de uma mesma e única categoria}

Ressalvada a regra 13.1, será permitido incluir no mesmo pedido internacional duas ou mais reivindicações independentes da mesma categoria (a saber: produto, processo, aparelho ou uso), que não possam ser facilmente abrangidas por uma única reivindicação genérica.

\subsection{Reivindicações dependentes}

Ressalvada a regra 13.1, será permitido incluir no mesmo pedido internacional um número razoável de reivindicações dependentes, referentes a formas específicas da invenção reivindicada em uma reivindicação independente, mesmo quando as características de qualquer reivindicação dependente possam ser consideradas como constituindo em si mesmas uma invenção.

\subsection{Modelos de utilidade}

Qualquer Estado designado no qual um modelo de utilidade seja requerido com base de um pedido internacional poderá aplicar, em lugar das regras 13.1 a 13.4, a respeito do assunto nelas disposto, as disposições de sua legislação nacional concernentes a modelos de utilidade depois de iniciado, nesse Estado, o processo de pedido internacional, desde que seja concedido ao depositante um prazo de pelo menos 2 meses a contar da data de expiração do prazo aplicável em obediência ao artigo 22 para que adapte seu pedido às exigências das referidas disposições da legislação nacional.

\section{Regra 14}

\section{Taxa de Transmissão}

\subsection{Taxa de transmissão}

a) Qualquer Repartição receptora poderá exigir em seu provento, que o depositante lhe pague uma taxa pelo recebimento do pedido internacional, pela transmissão de cópias ao Escritório Internacional e à Administração competente encarregada da pesquisa internacional e pela execução de todas as demais tarefas relativas ao pedido internacional, que essa Repartição tiver a seu cargo em virtude de sua qualidade de Repartição receptora ("taxa de transmissão").

b) O montante da taxa de transmissão, caso haja uma, e a data em que será devida, serão fixados pela Repartição receptora.

\section{Regra 15}

\section{Taxa internacional}

\subsection{Taxa básica e taxa de designação}

Qualquer pedido internacional será sujeito ao pagamento de uma taxa em proveito do Escritório internacional ("taxa internacional") compreendendo:

I) uma "taxa básica" e

II) tantas "taxas de designação" quantos forem os Estados designados incluídos no pedido internacional, desde que, no caso de uma patente regional ser requerida para certos Estados designados, uma única taxa de designação seja devida para todos esse Estados.

\subsection{Montantes}

a) O Montante da taxa básica será:

I) caso o pedido internacional não tenha mais de 30 folhas: 45 dólares dos Estados Unidos ou 194 francos suíços;

II) caso o pedido internacional contenha mais de 30 folhas: 45 dólares dos Estados Unidos mais 1 dólar dos Estados Unidos ou 4,30 francos suíços por folha a contar da 31 inclusive.

b) O montante da taxa de designação será: 
I) por cada Estado designado ou grupo de Estados designados para os quais seja requerida a mesma patente regional que não exija a transmissão de uma cópia segundo o artigo 13: 12 dólares dos Estados Unidos ou 52 francos suíços;

II) por cada Estado designado ou grupo de Estados designados para os quais seja requerida a mesma patente regional exigindo a transmissão de uma cópia de acordo com o artigo 13: 14 dólares dos Estado Unidos ou 60 francos suíços.

\subsection{Forma de pagamento}

a) A taxa internacional será cobrada pela Repartição receptora.

b) A taxa internacional deverá ser paga na moeda determinada pela Repartição receptora, ficando compreendido que, logo que seja transferida pela Repartição receptora para o Escritório Internacional, ela deverá ser livremente conversível em moeda suíça.

15.4 Data do pagamento

a) A taxa básica será devida na data do recebimento do pedido internacional, todavia, qualquer Repartição receptora poderá, a seu critério, notificar o depositante de que não recebeu essa taxa ou de que o montante recebido foi insuficiente e autorizá-lo a pagar mais tarde, sem perder a data do depósito, desde que:

I) não seja nunca autorizada a efetivação de um pagamento depois de expirado o prazo de um mês a contar do dia de recebimento do pedido internacional;

II) uma tal autorização não seja sujeita a uma sobretaxa.

b) A taxa de designação poderá ser paga na data de recebimento do pedido internacional ou em qualquer outra data posterior, mas deverá ser paga no máximo antes de completado um ano a contar da data de prioridade.

\subsection{Pagamento parcial}

a) Se o depositante especificar os Estados em relação aos quais deseja que qualquer montante pago por ele seja considerado como taxa de designação, esse montante será consequentemente aplicado, na ordem que o depositante indicar, aos Estados cuja taxa de designação for coberta pelo montante pago.

b) Se o depositante não fornecer tal especificação e se o montante ou montantes recebidos pela Repartição receptora forem superiores à taxa básica e a uma taxa de designação, mas inferiores ao montante que seria devido de acordo com o número dos Estados designados, todo o montante que exceder o total da taxa básica e de uma taxa de designação, será considerado como taxa de designação dos Estados seguintes ao Estado mencionado em primeiro lugar no requerimento e na ordem de designação desses Estados, no requerimento, até e inclusive aquele dentre os Estados designados em relação ao qual o montante integral da taxa de designação estiver coberto pelo montante ou montantes pagos.

c) Todos os Estados de um grupo de Estados designados, para os quais a mesma patente regional seja requerida, serão considerados como cobertos pela taxa de designação daquele desses Estados, que no sentido de alínea a) tiver sido mencionado em primeiro lugar, ou cuja taxa esteja no sentido da alínea $b$ ).

\subsection{Reembolso}

a) A taxa internacional será reembolsada ao depositante desde que seja negativa a constatação mencionada no artigo 11.1).

b) A taxa internacional não será reembolsada em nenhum outro caso. 


\section{Regra 16}

Taxa de pesquisa

\subsection{Direito de exigir uma taxa}

a) Qualquer Administração encarregada da pesquisa internacional poderá exigir do depositante o pagamento, em seu proveito, de uma taxa ("taxa de pesquisa") para realização da pesquisa internacional e para a execução de todas as demais tarefas confiadas às Administrações encarregadas da pesquisa internacional pelo Tratado e pelo presente Regulamento de execução.

b) A taxa de pesquisa será cobrada pela Repartição receptora e deverá ser paga na moeda estipulada por essa Repartição, ficando estendido, entretanto, que se essa moeda não for a mesma que a do Estado no qual a Administração encarregada da pesquisa internacional estiver sediada, a taxa de pesquisa, ao ser transferida pela Repartição receptora para essa Administração, será livremente conversível na moeda do dito Estado. Quanto ao prazo de pagamento da taxa de pesquisa, aplique-se a regra 15.4.a).

\subsection{Reembolso}

A taxa de pesquisa será reembolsada ao depositante desde que seja negativa a constatação mencionada no artigo 11.1).

\subsection{Reembolso parcial}

Quando o pedido internacional reivindicar a prioridade de um pedido internacional anterior que tenha sido objeto de uma pesquisa internacional pela mesma Administração encarregada da pesquisa internacional, essa Administração reembolsará a taxa de pesquisa paga em relação ao pedido internacional posterior na medida e nas condições estipuladas no acordo a que se refere o artigo 16.3)b),desde que o relatório de pesquisa internacional tenha podido basear-se, no todo ou em parte, nos resultados da pesquisa internacional do primeiro pedido internacional.

\section{Regra 17}

Documento de prioridade

\subsection{Obrigação de apresentar cópia de um pedido nacional anterior}

a) Se o pedido internacional reivindicar, de acordo com o artigo 8, a prioridade de um pedido nacional anterior, uma cópia desse pedido nacional, certificada devidamente pela Repartição nacional em que foi depositada ("documento de prioridade"), se já não houver sido depositada na Repartição receptora juntamente com o pedido internacional deverá ser apresentada pelo depositante ao Escritório Internacional, o mais tardar até a expiração de um prazo de 16 meses a contar da data de prioridade ou, no caso mencionado no artigo 23.2), o mais tardar na data estabelecida para processar e examinar o pedido.

b) Se o depositante não se conformar com a determinação da alínea $a$ ), qualquer Estado designado poderá desprezar a reivindicação de prioridade.

c) O Escritório Internacional inscreverá a data de recebimento do documento de prioridade e a notificará ao depositante e às Repartições receptoras.

\subsection{Disponibilidade de cópias}

a) O Escritório Internacional, a pedido expresso da Repartição designada, sem demora, mas não antes de expirado o prazo fixado na regra 17.1.a), enviará uma cópia do documento de prioridade àquela Repartição. Nenhuma Repartição designada deverá exigir cópias do depositante, exceto quando requerer a remessa de uma cópia do documento de prioridade com uma tradução certificada desse documento. O depositante não será obrigado a fornecer uma tradução certificada à Repartição designada antes de expirado o prazo estipulado no artigo 22. 
b) O Escritório Internacional não colocará à disposição do público cópias do documento de prioridade antes da publicação internacional do pedido internacional.

c) As alíneas $a$ ) e $b$ ) aplicam-se igualmente a qualquer pedido internacional anterior cuja prioridade seja reivindicada no pedido internacional posterior.

Regra 18

Depositante

\subsection{Domicílio}

a) Com ressalva da alínea $b$ ), a questão de saber se um depositante está domiciliado no Estado contratante em que alega estar dependerá da legislação nacional desse Estado e será resolvido pela Repartição receptora.

b) De qualquer maneira, a posse de um estabelecimento industrial ou comercial efetivo e idôneo em um Estado contratante será considerado como constituindo domicílio nesse Estado.

\subsection{Nacionalidade}

a) Com ressalva da alínea $b$ ), a questão de saber se o depositante é nacional do Estado contratante do qual alega ser, dependerá da legislação nacional desse Estado e será resolvida pela Repartição receptora.

b) De todo modo, uma pessoa jurídica constituída de acordo com a legislação de um Estado contratante será considerada como sendo nacional desse Estado.

\subsection{Vários depositantes: os mesmos para todos os Estados designados}

Se todos os depositantes forem depositantes em todos os Estados designados, o direito de depositar um pedido internacional existirá desde que pelo menos um dentre eles seja autorizado a depositar um pedido internacional de acordo com o artigo 9.

18.4 Vários depositantes: diferentes para Estados designados diferentes

a) O pedido internacional poderá indicar depositantes diferentes para Estados designados diferentes, desde que em relação a cada Estado designado, pelo menos um dos depositantes indicados para esse Estado esteja autorizado a depositar um pedido internacional de acordo com o artigo 9.

b) Caso a condição estabelecida na alínea $a$ ) não for preenchida em relação a um Estado designado, a designação desse Estado será considerada como não tendo sido feita.

c) O Escritório Internacional publicará, de tempos a tempos, informações relativas às diversas legislações nacionais quanto à questão de saber quem tem direito (inventor, procurador do inventor, titular da invenção, etc.) de depositar um pedido internacional e juntará a essas informações a advertência de que os efeitos do pedido internacional em qualquer Estado designado poderão depender da questão de saber se a pessoa indicada no pedido internacional como depositante para os propósitos desse Estado estará habilitada, de acordo com a legislação nacional desse Estado, a depositar um pedido nacional.

18.5 Troca de pessoa ou do nome do depositante

Qualquer troca de pessoa ou do nome do depositante será registrada, a pedido do mesmo, pelo Escritório Internacional que assim notificará a Administração internacional encarregada da pesquisa internacional e as Repartições designadas.

Regra 19

Repartição receptora competente

19.1 Onde depositar 
a) com ressalva da alínea b), o pedido internacional será depositado, à escolha do depositante, quer na Repartição nacional do Estado contratante onde estiver domiciliado, ou numa Repartição agindo em nome desse Estado, quer na Repartição nacional do Estado contratante de que for nacional, ou numa Repartição agindo em nome desse Estado.

b) Qualquer Estado contratante poderá estabelecer convênio com um ou outro Estado contratante ou com uma organização intergovernamental no sentido de que a Repartição nacional deste último Estado ou essa organização intergovernamental poderão, para todos os fins ou para certos dentre eles, agir em lugar da Repartição nacional do primeiro Estado como Repartição receptora para os depositantes domiciliados nesse primeiro Estado ou que dele sejam nacionais. Não obstante esse convênio, a Repartição nacional do primeiro Estado será considerada como sendo a Repartição receptora competente no sentido estabelecido pelo artigo 15.5).

c) Em relação a qualquer decisão de acordo com o artigo 9.2), a Assembléia designará a Repartição nacional ou a organização intergovernamental que funcionará como repartição receptora dos pedidos depositados por pessoas domiciliadas nos Estados determinados pela Assembléia ou nacionais desses Estados. Essa designação requer o acordo prévio da dita Repartição nacional ou da dita organização intergovernamental.

\subsection{Vários depositantes}

a) Se houver vários depositantes que não tenham mandatário comum, seu representante comum, no sentido que lhe empresta a regra 4.8, para fins da aplicação da regra 19.1, será considerado como depositante.

b) Se houver vários depositantes que tenham um mandatário comum, o depositante mencionado em primeiro lugar no requerimento com autoridade para depositar um pedido internacional de acordo com o artigo 9 será, para fins da aplicação da regra 19.1, considerado como depositante.

19.3 Publicação do fato da delegação de tarefas de Repartição receptora

a) Qualquer acordo previsto na regra 19.1.b) será notificado sem demora ao Escritório Internacional pelo Estado contratante que delegar as tarefas de Repartição receptora à Repartição nacional de, ou agindo em nome de outro Estado contratante ou uma organização intergovernamental.

b) O Escritório Internacional, prontamente depois do recebimento, publicará a notificação na Gazeta.

\section{Regra 20}

Recebimento do pedido internacional

\subsection{Data e número}

a) Ao receber os documentos que pretendam constituir um pedido internacional, a Repartição receptora aporá, de maneira indelével, no espaço previsto para este fim no formulário de requerimento de cada via recebida, a data do recebimento efetivo e, em cada folha de cada via recebida, um dos números atribuídos pelo escritório Internacional a essa Repartição.

b) O lugar em que, em cada folha, a data ou número deverão ser apostos, bem como outros pormenores, serão especificados nas Instruções Administrativas.

\subsection{Recebimento em dias diferentes}

a) Nos casos em que todas as folhas pertencentes a um mesmo alegado pedido internacional não sejam recebidas no mesmo dia pela Repartição receptora, esta última corrigirá a data aposta no requerimento (deixando, todavia, legíveis a ou as datas anteriormente apostas), indicando a data de recebimento dos documentos que completam o pedido internacional, contanto que: 
I) quando nenhuma solicitação tenha sido feita ao depositante para que efetue correções de acordo com o artigo 11.2)a), os ditos documentos sejam recebidos dentro de 30 dias a contar da data em que as folhas tenham sido recebidas pela primeira vez;

II) quando uma solicitação para efetuar correções tenha sido feita ao depositante, de acordo com o artigo 11.2)a), os ditos documentos sejam recebidos dentro do prazo estipulado pela regra 20.6;

III) no caso do artigo 14.2) os desenhos omissos sejam recebidos dentro de 30 dias a contar da data em que os documentos incompletos foram depositados;

IV) a falta ou recebimento posterior de qualquer folha contendo o resumo ou parte dele não exige por si só qualquer correção da data indicada no requerimento.

b) A Repartição receptora aporá em qualquer folha recebida em data posterior àquela em que as folhas foram recebidas pela primeira vez, a data do recebimento da folha em questão.

20.3 Pedido internacional corrigido

No caso mencionado no artigo 11.2)b), a Repartição receptora corrigirá a data aposta no requerimento (deixando, todavia, legíveis a data ou datas apostas anteriormente), indicando a data do recebimento da última correção exigida.

20.4 Constatação conforme especifica o artigo 11.1)

a) Prontamente, depois do recebimento dos documentos que constituem um alegado pedido internacional, a Repartição receptora constatará se esses documentos preenchem as condições prescritas pelo artigo 11.1).

b) Para os fins do artigo 11.1) III) c), bastará indicar o nome do depositante de maneira a permitir que seja estabelecida a sua identidade, mesmo se esse nome estiver mal ortografado, se os nomes indicados não estiverem completos ou, no caso de pessoa jurídica, se a indicação do nome estiver abreviada ou incompleta.

\subsection{Constatação positiva}

a) Se a constatação, no sentido que lhe empresta o artigo 11.1), for positiva, a Repartição receptora carimbará, no espaço reservado para esse fim no formulário do requerimento, o nome dessa Repartição as palavras "Demande Internationale PCT" ou "PCT International Application". Se a língua oficial da Repartição receptora não for nem francês, nem inglês, as palavras "Demande Internationale" ou "International Application" poderão ser acompanhadas por sua tradução na língua oficial dessa Repartição receptora.

b) A via cuja folha de requerimento foi assim carimbada, constituirá a via original do pedido internacional.

c) A Repartição receptora notificará sem demora ao depositante o número do pedido internacional e a data do deposito internacional.

20.6 Solicitação de correção

a) A solicitação de correção a que se refere o artigo 11.2) deverá especificar qual a condição prescrita pelo artigo 11.1) que, na opinião da Repartição receptora, não foi preenchida.

b) A Repartição receptora enviará sem demora a solicitação ao depositante e fixará um prazo razoável no caso para que deposite a correção. Esse prazo não deverá ser inferior a 10 dias, nem superior a um mês, a contar da data da solicitação. Se esse prazo expirar depois de decorrido um ano a contar da data do depósito de qualquer pedido cuja prioridade tenha sido reivindicada, a Repartição receptora poderá levar essa circunstância ao conhecimento do depositante. 


\subsection{Constatação negativa}

Caso a Repartição receptora não receba, no prazo estipulado, qualquer resposta a sua solicitação de correção, ou caso a correção apresentada pelo depositante não preencha ainda as condições prescritas pelo artigo 11.1):

I) ela notificará sem demora ao depositante que seu pedido não foi e não será considerado como um pedido internacional e indicará os motivos dessa decisão;

II) ela notificará ao Escritório Internacional que o número que foi por ela aposto nos documentos não será utilizado como número de pedido internacional;

III) ela conservará os documentos que constituem o alegado pedido internacional e qualquer correspondência relativa ao mesmo, de acordo com a regra 93.1; e

IV) ela enviará uma cópia dos ditos documentos ao Escritório Internacional caso, em virtude de um pedido do depositante de acordo com o artigo 25.1), o Escritório Internacional tenha necessidade de uma tal cópia e a solicite expressamente.

\subsection{Erro da Repartição receptora}

Se, mais tarde, a Repartição receptora descobrir, ou perceber pela resposta do requisitante, que cometeu um erro ao enviar uma solicitação de correção, em virtude de haverem sido devidamente preechidas as condições prescritas no artigo 11.1 na ocasião do recebimento dos documentos, ela procederá da forma prevista na regra 20.5.

\subsection{Cópia autenticada para o depositante}

Contra o pagamento de uma taxa, a Repartição receptora fornecerá ao depositante, a pedido, cópias autenticadas do pedido internacional, tal qual foi depositado assim como de todas as correções relativas ao mesmo.

\section{Regra 21}

\section{Preparo de cópias}

\subsection{Responsabilidade da Repartição receptora}

a) Quando for exigido que o pedido internacional seja depositado em uma única via, a Repartição receptora será responsável pelo preparo de sua própria cópia e da de pesquisa requeridas em virtude do artigo 12.1).

b) Quando for exigido que o pedido internacional seja depositado em duas vias, a Repartição receptora será responsável pelo preparo da cópia que lhe é destinada.

c) Se o pedido internacional for depositado em um número de vias inferir ao que foi prescrito na regra 11.1.b), a Repartição receptora será responsável pelo rápido preparo do número exigido de cópias, e terá o direito de fixar uma taxa para a execução dessa tarefa, bem como de cobrar essa taxa do depositante.

\section{Regra 22}

Transmissão da via original

\subsection{Processo}

a) Se a constatação a que se refere o artigo 11.1), for positiva e a menos que as estipulações relativas à segurança nacional impeçam que o pedido internacional seja considerado como tal, a Repartição receptora transmitirá a via original ao Escritório Internacional. Essa transmissão será feita sem demora após recebimento do pedido internacional ou, se houver necessidade de efetuar um controle a fim de preservar a segurança nacional, tão logo seja obtida a devida autorização. De todo modo, a Repartição receptora transmitirá a via original a tempo de chegar ao Escritório Internacional antes de expirados 13 meses a contar da data de prioridade. Caso a transmissão seja 
feita pelo correio, a Repartição receptora despachará a via original, ou mais tardar, 5 dias antes da expiração do $13^{\circ}$ mês a contar da data de prioridade.

b) Se, depois de expirado o prazo de 13 meses e 10 dias a contar da data de prioridade, o depositante não estiver de posse de notificação de recebimento enviada pelo Escritório Internacional de acordo com a regra 24.2.a), ele terá o direito de solicitar à Repartição receptora que lhe remeta a via original ou, se a Repartição receptora alegar haver transmitido a via original ao Escritório Internacional, uma cópia autenticada da via em questão feita à base da cópia da Repartição receptora.

c) O depositante poderá transmitir ao Escritório Internacional a cópia que recebeu de acordo com a alínea $b$ ). A menos que a via original transmitida pela Repartição receptora tenha sido recebida pelo Escritório Internacional antes do recebimento por esse Escritório da cópia transmitida pelo depositante, esta última será considerada como constituindo a via original.

\subsection{Processo alternativo}

a) Não obstante as disposições da regra 22.1, qualquer Repartição receptora poderá estipular que a via original de qualquer pedido internacional depositado junto a ela seja transmitida, à escolha do depositante, pela Repartição receptora ou pelo depositante. A Repartição receptora informará o Escritório Internacional da existência de uma tal estipulação.

b) O depositante exercerá sua escolha por meio de uma nota escrita que ele depositará junto com o pedido internacional. Caso não faça essa escolha, será considerado como tendo escolhido a transmissão pela Repartição receptora.

c) Quando o depositante escolher a transmissão pela Repartição receptora,o processo será o mesmo que o previsto na regra 22.1.

d) Quando o depositante preferir proceder ele próprio à transmissão, indicará na nota mencionada na alínea $b$ ) se deseja procurar a via original na Repartição receptora ou se deseja que esta última lhe envie a via origina pelo correio. Se o depositante preferir procurar ele mesmo a via original, a Repartição receptora colocará essa via à sua disposição assim que a autorização mencionada na regra 22.1.a) haja sido conseguida e, em todos os casos, inclusive no caso em que um controle deva ser efetuado em vista dessa autorização, 10 dias o mais tardar antes de expirado o $13^{\circ}$ mês a contar da data de prioridade. Se ao expirar o prazo de recebimento da via original pelo Escritório Internacional, o depositante ainda não houver procurado a mesma, a Repartição receptora o notificará ao Escritório Internacional. Se o depositante desejar que a Repartiçção receptora lhe envie a via original pelo correio ou se não manifestar o desejo de procurar essa via original, a Repartição receptora lhe enviará a mesma pelo correio assim que a autorização mencionada na regra 22.1.a) haja sido conseguida e, em todos os casos, inclusive no caso em que um controle deva ser efetuado em vista dessa autorização, 15 dias o mais tardar antes da expiração do $13^{\circ}$ mês a contar da data de prioridade.

e) Se a Repartição receptora não colocar a via original à disposição do despositante na data indicada na alínea $d$ ), ou se o depositante, havendo solicitado que a via original lhe fosse enviada pelo correio, não a tenha recebido pelo menos 10 dias antes de expirado o $13^{\circ}$ mês a contar da data de prioridade, o depositante poderá transmitir uma cópia de seu pedido internacional ao Escritório Internacional. Essa cópia (<<via original provisória >>) será substituída pela via original ou, caso esta última tenha sido perdida, por uma cópia da via original feita com base na cópia da Repartição receptora e devidamente autenticada pela Repartição receptora, tão logo seja possível e , em qualquer caso, antes da expiração do $14^{\circ}$ mês a contar da data de prioridade.

22.3 Prazo previsto no artigo 12.3)

a) O prazo previsto no artigo 12.3) será:

I) No caso de aplicação do processo previsto nas regras 22.1 ou 22.2.c), de 14 meses a contar da data de prioridade; 
II) No caso de aplicação do processo previsto na regra 22.2.d), de 13 meses a contar da data de prioridade, ficando entendido, entretanto, que,no caso de depósito de uma via original provisória de acordo com a regra 22.2.e), esse prazo será de 13 meses a contar da data de prioridade para o depósito da via original provisória e de 14 meses a contar da data de prioridade para depósito da via original.

b) $\mathrm{O}$ artigo 48.1) e a regra 82 não se aplicam à transmissão da via original. Fica entendido que as disposições do artigo 48.2) permanecem aplicáveis.

\subsection{Estátisticas referentes à não-conformidades às regras 22.1 e 22.2}

O número dos casos em que, com o conhecimento do Escritório Internacional, uma Repartição receptora não se tenha conformado às exigências das regras 22.1 e/ou 22.2 será indicado uma vez por ano na Gazeta.

\subsection{Documentos depositados com o pedido internacional}

Para os propósitos da presente regra, a expressão $<<$ via original $>>$ compreenderá igualmente qualquer documento depositado com o pedido internacional e mencionado na regra 33.3.a)II). Caso qualquer dos documentos mencionados na regra 3.3.a)II) que, de acordo com a lista de controle deveriam acompanhar o pedido internacional, não for efetivamente depositado, o mais tardar, na ocasião em que a via original for transmitida pela Repartição receptora, esta anotará o fato na lista de controle que será considerada como não havendo mencionado o dito documento.

Regra 23

Transmissão da cópia de pesquisa

\subsection{Processo}

a) A cópia de pesquisa será transmitida pela Repartição receptora à Administração encarregada da pesquisa internacional o mais tardar no dia em que a via original for transmitida ao Escritório Internacional ou, de acordo com a regra 22.2.d), ao depositante.

b) Se o Escritório Internacional não houver recebido, da Administração encarregada da pesquisa internacional, nos 10 dias seguintes ao recebimento da via original, a informação de que essa Administração está de posse da cópia de pesquisa, o dito Escritório transmitirá sem demora uma cópia do pedido internacional à Administração encarregada da pesquisa internacional. Se esta Administração não se houver enganado ao afirmar que não estava da posse da cópia de pesquisa ao expirar o $13^{\circ}$ mês a contar da data de prioridade, o custo da elaboração de uma cópia para essa Administração será reembolsado pela Repartição receptora ao Escritório Internacional.

c) O número dos casos em que, com o conhecimento do Escritório Internacional, uma Repartição receptora deixou de observar a exigência da regra 23.1.a), será indicado, uma vez por ano, na Gazeta.

\section{Regra 24}

Recebimento da via original pelo Escritório Internacional

\subsection{Inscrição da data de recebimento da via original}

Ao receber a via original, o Escritório Internacional aporá a data de recebimento na folha que contém o requerimento e seu carimbo em cada folha do pedido internacional.

\subsection{Notificação de recebimento da via original}

a) Com ressalva das disposições da alínea $b$ ), o Escritório Internacional notificará prontamente ao depositante, à Repartição receptora, a Administração encarregada da pesquisa internacional e a todos os Estados designados o fato do recebimento da via original e a data desse recebimento. A notificação deverá identificar o pedido internacional por seu número, pela data do depósito internacional, pelo nome do depositante e pelo nome da Repartição receptora, além de indicar a 
data do depósito de qualquer pedido anterior cuja prioridade seja reivindicada. A notificação enviada ao despositante deverá igualmente conter a relação dos Estados designados aos quais foi enviada a notificação mencionada na presente alínea e deverá indicar, em relação a cada Estado designado, qualquer prazo aplicável de acordo com o artigo 22.3).

b) Se o Escritório Internacional receber a via original depois de expirado o prazo na regra 22.3, notificará este fato prontamente ao depositante, à Repartição receptora e à Administração encarregada da pesquisa internacional.

Regra 25

Recebimento da cópia de pesquisa pela Administração encarregada da pesquisa internacional

25.1 Notificação de recebimento da cópia de pesquisa

A Administração encarregada da pesquisa internacional notificará prontamente ao Escritório Internacional, ao depositante e - salvo se a Administração encarregada da pesquisa internacional for a Repartição receptora - à Repartição receptora o fato do recebimento da cópia de pesquisa e a data desse recebimento.

Regra 26

Controle e correções de certos elementos do pedido internacional

26.1 Prazo para o controle

a) A Repartição receptora enviará a solicitação de correção prevista no artigo 14.1)b), assim que possível e de preferência no prazo de um mês a contar da data de recebimento do pedido internacional.

b) Se a Repartição receptora enviar uma solicitação de correção tal como o dispõe o artigo 14.1)a)III) ou IV) (título omisso ou resumo omisso), comunicará esse fato à Administração encarregada da pesquisa internacional.

\subsection{Prazo para correção}

O prazo previsto no artigo 14.1)b), deverá ser razoável, levando em conta circunstâncias do caso em espécie, e será fixado, em caso, pela Repartição receptora. O prazo será de pelo menos um mês e, normalmente, de no máximo dois meses a contar da data da solicitação de correção.

26.3 Verificação das condições materiais no sentido que lhe empresta o artigo 14.1)a)V)

As condições materiais mencionadas na regra 11 serão verificadas na medida em que tiverem de ser preenchidas para o fim de uma publicação internacional razoável uniforme.

\subsection{Processo}

a) Qualquer correção submetida à Repartição receptora poderá constar de uma carta endereçada a essa Repartição desde que a correção seja de tal natureza que permita sua transferência para a via original sem prejudicar a clareza e a reprodução direta da folha para a qual a transferência deverá ser feita; em caso contrário, o depositante será solicitado a apresentar uma folha de substituição que inclua a correção; a carta que acompanha a folha de substituição deverá chamar a atenção para as diferenças entre a folha substituída e a folha de substituição.

b) A Repartição receptora aporá em cada folha de substituição o número do pedido internacional, a data em que foi recebido e o carimbo de identificação dessa Repartição. Ela conservará em seus arquivos, uma cópia da carta contendo a correção ou, quando a correção constar de uma folha de substituição, a folha de substituição, a carta que acompanhar a folha de substituição e uma cópia desta última folha.

c) A Repartição receptora transmitirá sem demora a carta e qualquer folha de substituição ao Escritório Internacional. O Escritorio Internacional transferirá para a via original as correções 
requeridas por carta, indicando a data de recebimento desta última pela Repartição receptora nela inserindo qualquer folha de substituição. A carta e toda e qualquer folha substituída serão conservadas nos arquivos do Escritório Internacional.

d) A Repartição receptora transmitirá sem demora à Administração encarregada da pesquisa internacional uma cópia da carta e de cada folha de substituição.

26.5 Correção de certos elementos

a) A Repartição receptora decidirá se o depositante apresentou a correção dentro do prazo estabelecido. Caso a correção haja sido apresentada no prazo estipulado, a Repartição receptora decidirá se o pedido internacional assim corrigido deverá ou não ser considerado como retirado.

b) A Repartição receptora aporá nos documentos contendo a correção a data de seu recebimento.

26.6 Desenhos omitidos

a) Se, de acordo com o artigo 14.2), o pedido internacional se referir a desenhos que não estejam de fato incluídos no pedido, a Repartição receptora indicará este fato no dito pedido.

b) A data de recebimento, pelo depositante, da notificação prevista no artigo 14.2) não terá efeito sobre o prazo fixado na regra 20.2.a)III).

\section{Regra 27}

Falta de pagamento de taxas

\subsection{Taxas}

a) Para os fins do artigo 14.3)a), deve-se entender por <<taxas prescritas pelo artigo 3.4)IV) >> a taxa de transmissão (regra 14), a parte da taxa internacional que constitui a taxa básica (regra 15.1.I), e a taxa de pesquisa (regra 16).

b) Para os fins do artigo 14.3)a) e b), deve-se entender por $<<$ taxa prescrita pelo artigo 4.2) $>>$ a parte da taxa internacional que constitui a taxa de designação (regra 15.1.II).

\section{Regra 28}

Falhas notadas pelo Escritório Internacional ou pela Administração encarregada da pesquisa internacional

\subsection{Nota relativa a certas falhas}

a) Se o Escritório Internacional ou a Administração encarregada da pesquisa internacional forem de opinião que o pedido internacional contém qualquer uma das falhas a que se refere o artigo 14.1)a)I), II) ou V), o Escritório Internacional, ou a Administração encarregada da pesquisa internacional, conforme o caso, chamará a atenção da Repartição receptora para essas falhas.

b) A Repartição receptora, salvo se não partilhar dessa opinião procederá da maneira prevista no artigo 14.1)b) e na regra 26.

\section{Regra 29}

Pedidos internacionais ou designações consideradas como retirados no sentido do artigo 14.1), 3) ou 4)

\subsection{Constatação da Repartição receptora}

a) Se a Repartição receptora declarar, conforme o artigo 14.1)b) e a regra 26.5 (falta de correção de certas falhas), ou de acordo com o artigo 14.3)a) (falta de pagamento das taxas prescritas pela regra 27.1.a), ou ainda de acordo com o artigo 14.4) (constatação ulterior de que as condições enumeradas nos pontos I) e III) do artigo 11.1) não foram preenchidas), que o pedido internacional será considerado como retirado: 
I) a Repartição receptora transmitirá ao Escritório Internacional a via original (se isto já não houver sido feito) e toda e qualquer correção apresentada pelo depositante;

II) a Repartição receptora notificará sem demora essa declaração ao depositante e ao Escritório Internacional, e este último notificará de acordo as Repartições nacionais interessadas;

III) a Repartição receptora não transmitirá a cópia de pesquisa da maneira estabelecida na regra 23 ou, se uma tal cópia já houver sido transmitida, notificará a Administração encarregada da pesquisa internacional sobre essa declaração;

IV) o Escritório Internacional não será obrigado a notificar ao depositante o recebimento da via original;

b) Se a Repartição receptora declarar, como o preceitua o artigo 14.3)b) (falta de pagamento da taxa de designação prescrita pela regra 27.1.b) que a designação de qualquer Estado designado foi considerada como retirada, a Repartição receptora notificará prontamente tal declaração ao depositante e ao Escritório Internacional. Este, por sua vez, notificará a Repartição receptora interessada.

\subsection{Constatações das Repartições designadas}

Quando os efeitos do pedido internacional cessarem em qualquer Estado designado, em virtude do artigo 24.1)III), ou nele substituirem em virtude do artigo 24.2), a Repartição designada competente notificará tal fato prontamente ao Escritório Internacional.

\subsection{Alertando a Reparão receptora para certos fatos}

Caso o Escritório Internacional ou a Administração encarregada da pesquisa internacional for de parecer que a Repartição receptora deve fazer uma constatação tal como estipulado no artigo 14.4), chamará a atenção dessa Repartição para os fatos pertinentes.

29.4 Notificação da intenção de fazer uma declaração de acordo com o artigo 14.4)

Antes de fazer qualquer declaração de acordo com o artigo 14.4) a Repartição receptora comunicará ao depositante a sua intenção e os motivos que a determinaram. Caso não concorde com a constatação provisória da Repartição receptora, o depositante poderá apresentar argumentos nesse sentido dentro do prazo de um mês a partir da notificação.

Regra 30

Prazo a que se refere o artigo 14.4)

\subsection{Prazo}

O prazo mencionado no artigo 14.4) será de 6 meses a contar da data do depósito internacional.

Regra 31

Cópias a que se refere o artigo 13

\subsection{Pedido de cópias}

a) Os pedidos de cópias conforme o artigo 13.1) poderão referir-se a todos os pedidos internacionais, a certos tipos desses pedidos ou a determinados desses pedidos que designem a Repartição nacional autora desse pedido. Tais pedidos de cópias deverão ser renovados todos os anos através de notificações transmitidas ao Escritório Internacional antes de 30 de Novembro do ano precedente por essa Repartição.

b) Os pedidos conforme o artigo 13.2)b) estarão sujeitos ao pagamento de uma taxa para cobertura das despesas de preparo e expedição das cópias. 


\subsection{Preparo das cópias}

O Escritório Internacional será responsável pelo preparo das cópias a que se refere o artigo 13.

Regra 32

Retirada do pedido internacional ou de designações

\subsection{Retiradas}

a) O depositante poderá retirar o pedido internacional antes da expiração de um prazo de 20 meses contados da data de prioridade, salvo em relação a qualquer Estado designado em que já tenha sido iniciado o processo ou exame nacional. Poderá retirar a designação de qualquer Estado designado antes da data em que o processo ou exame sejam iniciados nesse estado.

b) A retirada da designação de todos os Estados designados será considerada como uma retirada do pedido internacional.

c) A retirada deverá ser efetuada por meio de um aviso assinado enviado pelo depositante ao Escritório internacional ou, se a via original não houver sido remetida para o Escritório Internacional, à Repartição receptora. No caso previsto na Regra 4.8.b), o aviso deverá ser assinado por todos os depositantes.

d) Quando a via original já houver sido remetida para o Escritório Internacional, o fato da retirada e a data de recebimento do aviso contendo a retirada serão registrados pelo Escritório Internacional e comunicados sem demora por este último à Repartição receptora, ao depositante, às Repartições designadas afetadas pela retirada e, quando a retirada for referente ao pedido internacional e o relatório de pesquisa internacional ou a declaração mencionada no artigo 17.2)a) ainda não houverem sido elaborados, à Administração encarregada da pesquisa inernacional.

\section{Regra 33}

Estado da técnica pertinente para fins da pesquisa internacional

33.1 Estado da técnica pertinente para fins da pesquisa internacional

a) Para fins do artigo 15.2), o estado da técnica pertinente abrangerá tudo o que foi tornado acessível ao público em todos os recantos do mundo, por meio de divulgação escrita (inclusive desenhos e outras ilustrações) e que seja capaz de ajudar a decidir se a invenção reivindicada é nova ou não e se ela implica ou não em atividade inventiva (isto é, se ela é evidente ou não), contanto, porém, que sua colocação à disposição do público tenha ocorrido entes da data do depósito internacional.

b) Quando a divulgação escrita mencionar uma divulgação oral, um uso, uma exposição, ou quaisquer outros meios através dos quais o conteúdo da divulgação escrita foi tornado acessível ao público, e quando essa colocação à disposição do público tenha ocorrido em uma data anterior à do deposito internacional, o relatório de pesquisa internacional mencionará em separado este fato e a data em que ele ocorreu, caso a colocação à disposição do público da divulgação escrita haja ocorrido em uma data posterior à do depósito internacional.

c) Qualquer pedido publicado, assim como qualquer patente cuja data de publicação for posterior, mas cuja data de depósito - ou, quando for o caso, a data da prioridade reivindicada - for anterior à data do depósito internacional do pedido internacional objeto da pesquisa, e que fariam parte do estado da técnica pertinente para os fins do artigo 15.2) se houvessem sido publicados antes da data do depósito internacional, serão especialmente mencionados no relatório de pesquisa internacional.

\subsection{Ramos que a pesquisa internacional deverá abranger}

a) A pesquisa internacional deverá abranger todos os ramos técnicos e deverá tomar como base todos os processos de pesquisa que possam conter elementos pertinentes à invenção. 
b) Por conseguinte, a pesquisa não deverá abranger apenas o ramo da técnica na qual a invenção possa ser classificada, mas também ramos análogos, sem levar em conta sua classificação.

c) A questão de saber que ramos de técnica deverão, em um determinado caso, ser considerados como análogos, deverá ser estudada à luz do que parece constituir a função ou o uso necessário da invenção, e não unicamente as funções específicas expressamente indicadas no pedido internacional.

d) A pesquisa internacional deverá abranger todos os elementos que se consideram geralmente como equivalentes aos elementos da invenção reivindicada por todas ou certas características suas, mesmo se, em seus detalhes, a invenção, tal como foi descrita no pedido internacional, for diferente.

\subsection{Orientação da pesquisa}

a) A pesquisa internacional deverá ser feita à base das reivindicações, levando na devida conta a descrição e os desenhos (se os houver) e insistindo muito particularmente no conceito inventivo visado pelas reivindicações.

b) Na medida em que for possível e razoável, a pesquisa internacional deverá abranger todos os elementos visados pelas reivindicações ou que se possa razoavelmente esperar que elas visem após serem emendadas.

Regra 34

Documentação mínima

34.1 Definição

a) As definições contidas no artigo 2.I) e II) não se aplicarão às finalidades deste artigo.

b) A documentação mencionada no artigo 15.4) ("documentação mínima") consistirá em:

I) os "documentos nacionais de patentes" tal como especificado na alínea $c$ );

II) os pedidos internacionais (PCT) publicados, os pedidos regionais publicados de patentes e certificados de autor de invenção, assim como as patentes e os certificados de autor regionais publicados; todos os demais elementos que constituam a literatura não especializada em patentes, convencionados entre as Administrações encarregadas da pesquisa internacional e cuja lista for publicada pelo Escritório Internacional depois do primeiro acordo a seu respeito e depois de cada modificação.

c) Ressalvadas as disposições das alíneas $d$ ) e $e$ ), os "documentos nacionais de patentes" serão os seguintes:

I) as patentes concedidas a partir de 1920 pela França, pelo ex-Reichspatentamt da Alemanha, pelo Japão, a União Soviética, a Suíça (unicamente nas línguas francesa e alemã), o Reino Unido e os Estados Unidos da América;

II) as patentes concedidas pela República Federal da Alemanha;

III) os pedidos de patentes, se os houver, publicados a partir de 1920 nos países mencionados nos pontos I) e II);

IV) os certificados de autor de invenção concedidos pela União Soviética;

V) os certificados de utilidade concedidos pela França e os pedidos publicados desses certificados;

VI) as patentes concedidas depois de 1920 por qualquer outro país, se forem redigidas em alemão, inglês ou francês e se não contiverem qualquer reivindicação de prioridade, assim como os pedidos dessas patentes publicados depois de 1920, desde que a Repartição nacional do país interessado selecione esses documentos e os coloque à disposição de cada Administração encarregada da pesquisa internacional. 
d) Quando um pedido for publicado novamente uma (por exemplo, publicação de uma Offenlengungschrift como uma Auslegeschrift) ou mais vezes, nenhuma Administração encarregada da pesquisa internacional será obrigada a conservar todas as versões em sua documentação; por conseguinte, cada Administração encarregada da pesquisa internacional será autorizada a não conservar senão uma versão. Por outro lado, quando um pedido for aprovado e concedido na forma de uma patente ou de um certificado de utilidade (França) nenhuma Administração encarregada da pesquisa internacional será obrigada a conservar ao mesmo tempo o pedido e a patente ou o certificado de utilidade (França) em sua documentação; por conseguinte, qualquer Administração encarregada da pesquisa internacional será autorizada a guardar em seus arquivos quer o pedido, quer a patente ou o certificado de utilidade.

e) Qualquer Administração encarregada da pesquisa internaional cuja língua oficial ou uma das línguas oficiais não for o japonês ou o russo, será autorizada a não incluir em sua documentação os documentos de patentes do japão e da União Soviética respectivamente dos quais não haja resumo disponível em língua inglesa. Se os resumos em língua inglesa se tornarem disponíveis de maneira geral depois da entrada em vigor deste Regulamento de execução os documentos de patentes abrangidos pelos resumos deverão ser incluídos na documentação no decorrer dos 6 meses seguintes à data em que esses resumos se tornaram disponíveis de modo geral. Na eventualidade de interrupção dos serviços de resumos em inglês nos ramos da técnica em que tais resumos eram geralmente disponíveis, a Assembléia adotará as medidas necessárias a restaurar prontamente tais serviços nos ramos em questão.

f) Para os fins desta regra, os pedidos que houverem sido unicamente colocados à disposição do público para consulta não são considerados como pedidos publicados.

\section{Regra 35}

Administração competente encarregada da pesquisa internacional

35.1 Quando apenas uma Administração encarregada da pesquisa internacional for competente

Qualquer Repartição receptora comunicará ao Escritório Internacional em oberdiência aos termos de acordo a que se refere o artigo 16.3)b), que Administração encarregada da pesquisa internacional é competente para realizar a pesquisa relativa aos pedidos internacionais depositados na dita Repartição; O Escritório Internacional publicará prontamente essa informação.

35.2 Quando várias Administrações encarregadas da pesquisa internacional forem competentes

a) Qualquer Repartição receptora, conforme os termos do acordo aplicável mencionado no artigo 16.3)b), poderá designar várias Administrações encarregadas da pesquisa internacional:

I) declarando todas essas Administrações competentes em relação a qualquer pedido internacional depositado nessa Repartição e deixando a escolha entre essas Administrações a cargo do depositante, ou

II) declarando uma ou várias dessas Administrações competentes em relação a certos tipos de pedidos internacionais depositados nessa Repartição e declarando uma ou várias outras Administrações competentes em relação a outros tipos de pedidos internacionais depositados nessa Repartição, desde que a respeito dos tipos de pedidos internacionais em relação aos quais várias Administrações encarregadas da pesquisa forem declaradas competentes, a escolha caiba ao depositante.

b) Qualquer Repartição receptora que se valer da faculdade descrita na alínea $a$ ) disso informará prontamente o Escritório Internacional e este último publicará sem demora essa informação.

Regra 36

Exigências mínimas para as Administrações encarregadas da pesquisa internacional 
36.1 Definição das exigências mínimas

As exigências mínimas mencionadas no artigo 16.3)c) serão as seguintes:

I) a Repartição nacional ou a organização intergovernamental deverá ter pelo menos 150 funcionários de tempo integral possuindo habilitação técnica suficiente para realizar as pesquisas;

II) essa Repartição ou essa organização deverá possuir pelo menos a documentação mínima a que se refere a regra 34 adequadamente adaptada às finalidades da pesquisa;

III) essa Repartição ou essa organização deverá dispor de pessoal capaz de realizar a pesquisa nos ramos técnicos requeridos e possuindo conhecimentos linguísticos necessários à compreensão pelo menos das línguas em que a documentação mínima mencionada na regra 34 estiver redigida ou traduzida.

Regra 37

Título omisso ou defeituoso

\subsection{Título omisso}

Se o pedido internacional não possuir título e se a Repartição receptora houver notificado a Administração encarregada da pesquisa internacional que solicitou ao depositante a correção dessa falha, essa Administração procederá à pesquisa internacional, a menos que receba, e até que receba notificação de que o dito pedido internacional foi considerado como retirado.

\subsection{Colocação do título}

Se o pedido internacional não possuir título e se a Administração encarregada da pesquisa internacional não houver recebido notificação da Repartição receptora comunicando que o depositante foi solicitado a fornecer um título, ou se a dita Administração constatar que o título não está conforme a regra 4.3, essa Administração fornecerá ela própria um título.

Regra 38

Resumo omisso ou defeituoso

\subsection{Resumo omisso}

Se o pedido internacional não contiver resumo e se a Repartição receptora houver notificado à Administração encarregada da pesquisa internacional que solicitou ao depositante a correção dessa falha, essa Administração procederá à pesquisa internacional salvo se receber, e até que receba notificação de que o pedido internacional deverá ser considerado como retirado.

\subsection{Elaboração de resumo}

a) Se o pedido internacional não contiver resumo e se a Administração da pesquisa internacional não houver recebido notificação da Repartição receptora comunicando que o depositante foi solicidado a submeter um resumo, ou se a dita Administração constatar que o resumo não estar conforme à disposições da regra 8, essa Administração elaborará ela propria um resumo (na lingua de publicação do pedido internacional) e solicitará ao depositante que apresente seus comentários a respeito no prazo de um mês a contar da data dessa solicitação.

b) O conteúdo definitivo do resumo será determinado pela Administração encarregada da pesquisa internacional.

Regra 39

Matéria a que se refere o artigo 17.2(a)I) 


\subsection{Definição}

Nenhuma Administração encarregada da pesquisa internacional terá obrigação de proceder à pesquisa de um pedido internacional cuja matéria e na medida em, que a matéria seja uma das seguintes:

I) teorias científicas e matemáticas;

II) variedades vegetais, raças animais, processos essencialmente biológicos de produção de vegetais ou animais, além dos processos microbiológicos e produtos obtidos através desses processos;

III) planos, princípios ou métodos para a realização de negócios, de ações puramente intelectuais ou de jogos;

IV) métodos de tratamento do corpo humano ou animal pela cirurgia ou a terapia, assim como métodos de diagnóstico;

V) meras apresentações de informações;

VI) programas de computadores na medida em que a Administração encarregada da pesquisa internacional estiver desaparelhada para realizar a pesquisa do estado da técnica relativa a tais programas.

\section{Regra 40}

Falta de unidade da invenção (pesquisa internacional)

40.1 Solicitação de pagamento

A solicitação de pagamento das taxas adicionais de que trata o artigo 17.3)a) especificará o seu montante e os motivos que levaram a considerar que o pedido internacional não satisfaz a exigência de unidade de invenção.

40.2 Taxas adicionais

a) O montante da taxa adicional para a pesquisa, de que trata o artigo 17.3)a), será determinado pela Administração competente encarregada da pesquisa internacional.

b) A taxa adicional para a pesquisa, de que trata o artigo 17.3)a), deverá ser paga diretamente à Administração encarregada da pesquisa internacional.

c) Qualquer depositante poderá pagar a taxa sob protesto, isto é, juntando uma declaração fundamentada que demonstre que o pedido internacional preenche a condição de unidade da invenção ou que o montante da taxa adicional solicitada é excessivo. Uma comissão de três membros ou qualquer outra instância especial da Administração encarregada da pesquisa internacional, ou qualquer autoridade superior competente, examinará o protesto e, na medida em que o julgar justificado, ordenará o reembolso, total ou parcial, da taxa adicional ao depositante. A requerimento do depositante, o texto de seu protesto, bem como a da decisão sobre o mesmo serão comunicados às Repartições designadas, juntamente com o ralatório de pesquisa internacional. $\mathrm{O}$ depositante apresentará uma tradução de seu protesto juntamente com a tradução do pedido internacional exigido em virtude do artigo 22.

d) A comissão de três membros, a instância especial ou a autoridade superior a que se refere a alínea $c$ ) não deverão incluir qualquer pessoa que tenha participado da decisão objeto do protesto

\subsection{Prazo}

O prazo previsto no artigo 17.3)a) será fixado em cada caso e levando em conta as circunstâncias do caso em espécie, pela Administração encarregada da pesquisa internancional; não poderá ser inferior a 15 ou 30 dias respectivamente se o endereço do depositante for no mesmo país ou em 
outro país que aquele em que estiver seidada a Administração encarregada da pesquisa internacional, nem superior a 45 dias a contar da data de solicitação.

\section{Regra 41}

Pesquisa de tipo internacional

\subsection{Obrigação de utilizar os resultados; Reembolso da taxa}

Se, no requerimento, huver referência, na forma prvista na regra 4.11, a uma pesquisa de tipo internancional efetuada nas condições estabelecidas pelo Artigo 15.5), a Administração encarregada da pesquisa internacional utilizará, na medida do possível, os resultados dessa pesquisa para eleboração do relatório de pesquisa internacional relativo ao pedido internacional. A Administração encarregada da pesquisa internancional reembolsará a taxa de pesquisa, na medida e nas condições previstas no acordo a que se refere o artigo 16.3)b), caso o relatório de pesquisa internaional puder basear-se, no todo ou em parte, nos resultados da pesquisa de tipo internacional.

Regra 42

Prazo para a pesquisa internacional

\subsection{Prazo para a pesquisa internacional}

Todos os acordos concluídos com as Adminstrações encarregadas da pesquisa internancional devem prever o mesmo prazo para a elaboração do relatório de pesquisa internancional ou a declaração mencionada no artigo 17.2)a). Esse prazo não deverá exceder aquele dos dois períodos seguinte que expirar por último: 3 meses a contar do recebimento da cópia de pesquisa pela Administração encarregada da pesquisa internancional, ou 9 meses a contar da data de prioridade. Durante um período temporário de 3 anos a partir da entrada em vigor do Tratado, os prazos estabelecidos para o acordo com qualquer Administração encarregada da pesquisa internacional poderão ser negociados individualmente desde que esses prazos não excedam de dois meses aqueles mencionados na frase precedente, mas não poderão em hipótese alguma ultrapassar a expiração do $18^{\circ}$ mês seguinte à data de prioridade.

Regra 43

Relatório de pesquisa internacional

\subsection{Identificações}

O relatório de pesquisa internacional identificará a Administração encarregada da pesquisa internacional que o elaborou, indicando o nome dessa Administração, e identificará o pedido internacional indicando o número desse pedido, o nome do depositante, o nome da Repartição receptora e a data do depósito internacional.

\subsection{Datas}

O relatório de pesquisa internacional será datado e indicará a data em que a pesquisa internacional foi efetivamente concluída. Indicará também a data de depósito de qualquer pedido anterior cuja prioridade haja sido reivindicada.

\subsection{Classificação}

a) O relatório de pesquisa internacional conterá a classificação do objeto da invenção pelo menos segundo a Classificação Internacional das patentes.

b) Essa classificação será efetuada pela Administração encarregada da pesquisa internacional.

\subsection{Língua}

qualquer relatório de pesquisa internacional e qualquer declaração feita em cirtude do artigo 17.2)a), serão elaborados na língua de publicação do pedido internacional a que se referem. 


\subsection{Citações}

a) O relatório de pesquisa internacional citará os documentos considerados importantes.

b) O método de identificação de cada documento citado será especificado nas Instruções Administrativas.

c) As citações de particular importância serão especialmente apontadas.

d) As citações que não forem importantes para todas as reivindicações serão indicadas em relação à ou às reivindicações a que se referirem.

e) Se apenas certas passagens do documento citado forem importantes ou especialmente importantes, essas passagens serão identificados pela indicação, por exemplo, da página, da coluna ou das linhas em que figura a passagem em questão.

43.6 Ramos abrangidos pela pesquisa

a) O relatório de pesquisa internacional conterá a identificação por simbolos de classificação dos ramos abrangidos pela pesquisa. Se essa identificação for feita na base de uma classificação diferente da Classificação Internacional das Patentes, a Administração encarregada da pesquisa internacional publicará a classificação utilisada.

b) Se a pesquisa internaiconal abranger patentes, certificados de autor de invenção, certificados de utilidade, modelos de utilidade, patentes ou certificados de adição, certificados de autor de invenção adicionais, certificados de utilidade adicionais ou pedidos publicados de um dos tipos precedentes de proteção relativos a Estados, época ou línguas não compreendedos na documentação mínima tal como definida na regra 34, o relatório internaiconal de pesquisa identificará os tipos de documentos, os Estados, as épocas ou as línguas a que se referiu. O artigo 2.II) não será aplicável às finalidades desta alínea.

43.7 Observações a respeito da unidade da invenção

Se o depositante houver pago taxas adicionais pela pesquisa internacional, o relatório de pesquisa internacional o mencionará. Outrossim, quando a pesquisa internacional houver sido realizada apenas sobre a invenção principal (artigo 17.3)a)), o relatório de pesquisa internacional indicara que partes do pedido internacional a pesquisa abordou a que partes não abordou.

\subsection{Assinatura}

O relatório de pesquisa internacional será assinado por um funcionário autorizado da Administração encarregada da pesquisa internacional.

\subsection{Limitação do conteúdo}

O relatório de pesquisa internacional não conterá qualquer matéria além das enumeradas nas reguras 33.1.b) e c), 43.1, 2, 3, 5, 6, 7 e 8 e 44.2.a) e b), e a indicação mencionada no artigo 17.2)b). E sobretudo não conterá qualquer expressão de opinião, qualquer observação argumento, ou explicação.

\subsection{Forma}

As condições materiais quanto à forma do relatório de pesquisa internacional serão especificada nas Instituições Administrativas.

\section{Regra 44}

Transmissão do relatório de pesquisa internacional, etc. 
44.1 Cópias do relatório ou da declaração

A Administração encarregada da pesquisa internacional transmitirá, no mesmo dias, uma cópia do relatório de pesquisa internacional ou da declaração a que se refere o artigo 17.2)a) ao Escritório Internacional e uma cópia ao depositante.

\subsection{Título ou resumo}

a) Ressalvadas as alíneas $b$ ) e $c$ ), relatório de pesquisa internacional recomedará à Administração encarregada da pesquisa internacional que aprove o título e o resumo submetidos pelo depositante, ou anexará o texto do título e ou do resumo tal como elaborados pela Administração encarregada da pesquisa internacional de acordo com as regras 37 e 38.

b) Se, ao ser concluída a pesquisa internacional, o prazo concedido ao depositante para comentar todas as sugestões da Administração encarregada da pesquisa internacional relativas ao resumo não houver expirado, o relatório de pesquisa internacional mencionará que está incompleto no que diz respeito ao resumo.

c) Assim que expirar o prazo mencionado na alínea $b$ ), a Administração encarregada da pesquisa internacional notificará ao Escritório Internacional e ao depositante que o resumo foi aprovado ou elaborado por ela.

\subsection{Cópias de documentos citados}

a) O requerimento a que se refere o artigo 20.3) poderá ser apresentado a qualquer momento durante os 7 anos a partir da data do depósito internacional do pedido internacional a que se refere o relatório de pesquisa internacional.

b) A Administração encarregada da pesquisa internacional poderá exigir que a parte (depositante ou Repartição designada) que lhe apresentou o requerimento pague o custo do preparo e da expedição das cópias. O montante desse custo do preparo de cópias será estabelecido nos acordos a que ser refere o artigo 16.3)b) concluídos entre as Administrações encarregadas da pesquisa internacional e o Escritório Internacional.

c) Qualquer Administração encarregada da pesquisa internacional que não desejar transmitir cópias diretamente a qualquer Repartição designada enviará uma cópia ao Escritório Internacional que então procederá de acordo com as disposições das alíneas $a$ ) e $b$ ).

d) Qualquer Administração encarregada da pesquisa internacional poderá confiar as tarefas a que se referem as alíneas $a$ ) e $c$ ) a outro organismo que será reponsável perante ela.

Regra 45

Tradução do relatório de pesquisa internacional

\subsection{Línguas}

Os relatórios de pesquisa internacional e as declarações a que se refere o aritgo 17.2)a) serão traduzidos para o inglês quando não forem elaborados nessa língua.

Regra 46

Emenda das reivindicações junto ao Escritório Internacional

\subsection{Prazo}

O prazo mencionado no artigo 19 será de dois meses a contar da data de transmissão do relatório de pesquisa internacional ao Escritório Internacional e ao depositante pela Administração encarregada da pesquisa internacional ou, quando essa transmissão for efetuada antes de expirado o $14^{\circ}$ mês a contar da data de prioridade, de três meses a contar da data de transmissão. 


\subsection{Data de emendas}

A data de recebimento de qualquer emenda será registrada pelo Escritório Internacional e indicada por ele em todas as publicações ou cópias que elaborar.

\subsection{Língua das emendas}

Se o pedido internacional houver sido depositado numa língua diferente daquela usada na sua publicação pelo Escritório Internacional, qualquer emenda feita de acordo com o artigo 19 deverá ser efetuada tanto na língua em que o pedido internacional foi depositado como na língua em que foi publicado.

\subsection{Declaração}

a) A declaração encionada no artigo 19.1) deverá ser feita na língua de publicação do pedido internacional e não deverá exceder 500 palavras se for redigida em, ou traduzida para o inglês.

b) A declaração não deverá conter qualquer comentário relativo ao relatório de pesquisa internacional ou à pertinência das citações contidas nesse relatótio. A declaração não poderá se referir a uma citação contida no relatório de pesquisa internacional senão para indicar que uma determinada emenda das reivindicações tem por fim evitar o documento citado.

\subsection{Forma das Emendas}

a) O depositante será solicitado a apresentar uma folha de substituição para cada folha das reivindicações que devido a uma ou mais emendas feitas de acordo com o artigo 19, divirja da folha originalmente depositada. A carta que acompanhar as folhas de substituição deverá chamar atenção para as divergências entre as folhas substituídas e as folhas de substituição. Desde que uma emenda exija a supressão de uma folha inteira, essa emenda deverá ser comunicada por uma carta.

b) O Escritório Internacional anotará em uma folha de substituição, o número do pedido internacional, a data em que foi recebida a folha em questão e o carimbo que o identifica. Conservará em seus arquivos, toda e qualquer folha de substituição, a carta que acompanhar a ou as folhas de substituição e qualquer carta tal como mencionada na última frase da alínea $a$ ).

c) O Escritório Internacional inserirá toda e qualquer folha de substituição na via original e, no caso mencionado na última frase da alínea $a$ ), anotará as supressões na via original.

\section{Regra 47}

Comunicação às Repartições designadas

\subsection{Processo}

a) A comunicação a que se refere o artigo 20 será feita pelo Escritório Internacional.

b) Essa comunicação será feita prontamente após o Escritótio Internacional ter recebido do depositante emendas ou uma declaração de que ele não deseja apresentar emendas ao Escritório Internacional mas, de todo mudo, ao se expirar o prazo previsto na regra 46.1. Quando, em obediência ao artigo 17.2)a), a Administração encarregada da pesquisa internacional houver declarado que nenhum relatório de pesquisa internacional será efetuado, a comunicação a que se refere o artigo 20 será feita, salvo retirada do pedido internacional, dentro do prazo de um mês a contar da data em que o Escritório Internacional recebeu da Administração encarregada da pesquisa internacional a notificação relativa a essa declaração; à dita comunicação deverá ser juntada uma indicação da data da notificação enviada ao depositante de acordo com o artigo 17.2)a).

c) O Escritório Internacional enciará ao depositante uma nota indicando as Repartições nacionais às quais a comunicação foi feita e a data dessa comunicação. Essa nota será enviada no mesmo dia que a comunicação.

d) Cada Repartições designada receberá, apedido, os relatórios de pesquisa internaional e as declarações a que se refere o artigo 17.2)a) também em sua tradução, conforme a regra 45.1. 
e) Quando qualquer Repartição designada houver dispensado a exigência do requerimento prescrito pelo artigo 20, as cópias dos documentos que normalmente deveriam Ter sido enviadas a essa Repartição serão enviadas, a seu pedido ou a pedido do depositante, para este último ao mesmo tempo que a nota mencionada na alínea $c$ ).

\subsection{Cópias}

a) As cópias requeridas para as comunicações serão preparadas pelo Escritório Internacional.

b) Essas cópias deverão ser feitas em folhas de formato A4.

\subsection{Língua}

A comunicação do pedido internacional, de acordo com o artigo 20, deverá ser feita na língua de sua publicação, ficando entendido que, se essa língua não for a mesma em que o pedido foi depositado, este último será, a pedido da Repartição designada, comunicado em uma ou outra dessas línugas, ou em ambas.

Regra 48

Publicação internacional

48.1 Forma

a) O pedido internacional será julgado em forma de brochura.

b) Os pormenores relativos à forma da brochura e ao seu modo de reprodução serão especificados nas Instruções Administrativas.

48.2 Conteúdo

a) A brochura conterá:

I) uma página de cobertura padronizada;

II) a descrição;

III) as reivindicações;

IV) os desenhos, se os houver;

V) com ressalva da alínea $g$ ), o relatório de pesquisa internaional ou a declaração mencionada no artigo 17.2)a);

VI) qualquer declaração depositada em obediência ao artigo 19.1), salvo se o Escritório Internacional considerar que a declaração não esta conforme à disposições da regra 46.4 .

b) Com ressalva da alínea $c$ ), a página de cobertura compreederá:

I) dados retirados da folha que contém o requerimento e outros dados que serão especificados nas Instruções Administrativas;

II) uma ou mais ilustrações quando o pedido internacional contiver desenhos;

III) o resumo: caso o resumo seja redigido em inglês e em uma outra língua, o texto em inglês deverá figurar em primeiro lugar.

c) Quando, em obediência ao artigo 17.2)a), houver sido feita uma declaração, a página de cobertura evidenciará esse fato e não compreenderá desenhos nem resumo.

d) Quando as ilustrações mencionadas nas alíneas $b$ )II) forem escolhidas da maneira estabelecida pela regra 8.2, a reprodução dessa ilustração ou ilustrações na página de cobertura poderá ser em formato reduzido. 
e) Caso não haja espaço suficiente na página de cobertura para todo o resumo tal como mencionado na alínea $b$ )III), o mesmo poderá ser apresentado no verso da página de cobertura. O mesmo se aplica à tradução do resumo quando essa tradução tiver de ser publicada em obediência à regra 48.3.c).

f) Se as reivindicações hoverem sido emendadas de acordo com o artigo 19, a publicação conterá quer o texto integral das reivindicações tal como foram depositadas e tal como foram emendadas, que o texto integral das reivindicações tal como foram depositdas, especificando todas as emendas. Qualquer declaração de acordo com o artigo 19.1 será igualmente incluída, a menos que o Escritório Internacional julgue que a mesma não está conforme às disposições da regra 46.4. A data de recebimento pelo Escritório Internacional das reivindicações emendadas deverá ser indicada.

g) Se, na ocasião estabelecida para a publicação, o relatório de pesquisa internacional ainda não estiver disponível (em virtude, por exemplo, de publicação a pedido do depositante de acordo com os artigos 21.2)b) e 64.3)c)I)), á brochura conterá, em lugar do relatório de pesquisa internacional, a indicação de que esse relatório ainda não está disponível e que, ou a brochura (contendo então também o relatório internacional) será publicada novamente, ou o relatório de pesquisa internacional (quando estiver disponível) será publicado separadamente.

h) Se, na data estabelecida para a publicação, o prazo para emendas das reivindicações, estipulado pelo artigo 19, não houver expirado, a brochura indicará esse fato e especificará que, se as reivindicações tiverem de ser modificadas de acordo com o artigo 19, haverá, logo após essas modificações, quer nova publicação (da bruchura incluindo as reinvindicações como foram emendadas), quer publicação de uma declaração reproduzindo todas as emendas. No último caso, haverá, pelo menos, nova publicação da página de cobertura e das reivindicações em caso de depósito de uma declaração em virtude do artigo 19.1), publicação dessa declaração, a menos que o Escritório Internacional julgue que a declaração não está conforme às disposições da regra 46.4.

i) As Instruções Administrativas determinarão os casos em que as diversas alternativas mencionadas nas alíneas $g$ ) e $h$ ) serão aplicadas. Essa determinação dependerá do volume e da complexidade das emendas e/ou do volume do pedido internacional e de fatores de custo.

\subsection{Línguas}

a) Se o pedido internacional for depositado em alemão, em francês, em inglês, em japonês ou em russo, ele será publicado na língua em que foi depositado.

b) Se o pedido internacional for depositado em uma língua que não seja alemão, francês, inglês, japonês ou russo, será publicado em tradução inglesa. A tradução será feita sob a responsabilidade da Administração encarregada da pesquisa internacional que deverá tê-la pronta em tempo suficiente para que a publicação internacional a que se refere o artigo 20 seja feita na data prevista. Não obstante as disposições da regra 16.1.a), a Administração encarregada da pesquisa internacional poderá perceber uma taxa do depositante pela tradução. A administração encarregada da pesquisa internacional dará oportunidade ao depositante para comentar a minuta da tradução e estipulará um prazo razoável, na circunstância, para a apresentação desses comentários. Caso não haja tempo para levar e consideração os comentários do depositante antes da comunicação da tradução, ou se houver divergência de opiniões entre o depositante e a dita Administração quanto à exatidão da tradução, o depositante poderá enviar uma cópia de seus comentários ou o que restar dos mesmos, ao Escritório Internacional e a cada Repartição designada à qual a tradução foi comunicada. O Escritório Internacional publicará a essência dos comentários juntamente com a tradução da Administração encarregada da pesquisa internacional ou depois da publicação dessa tradução.

c) Se o pedido internacional for publicado em uma língua que não seja o inglês, o relatório de pesquisa internacional, ou a declaração a que se refere o artigo 17.2)a), e o resumo serão publicados ao mesmo tempo nessa outra língua e em inglês. As traduções serão feitas sob a responsabilidade do Escritório Internacional. 
48.4 Publicação antecipada a pedido do depositante

a) Quando o depositante pedir a publicação tal como o facultam os artigos 21.2)b) e 64.3)c)i) e quando o relatório de pesquisa internacional ou a declaração a que se refere o artigo 17.2)a) ainda não estiver disponível para publicação com o pedido internacional, o Escritório Internacional cobrirá uma taxa especial de publicação cujo montante será fixado nas Instruções Administrativas.

b) A publicação de acordo com os artigos 21.2)b) e 64.3)c)i) será feita pelo Escritório Internacional logo após o deposittante havê-la solicitado e, quando uma taxa especial for devida em virtude da alínea $a$ ), depois do recebimento dessa taxa.

48.5 Notificação da publicação nacional

Quando a publicação do pedido internacional pelo Escritório Internacional for regulamentada pela disposição do artigo 64.3)c)ii), a Repartição nacional interessada, logo após haver efetuado a publicação nacional mencionada na dita disposição, notificará o fato dessa publicação nacional ao Escritório Internacional.

48.6 Publicação de certos fatos

a) Se qualquer notificação a que se refere a regra 29.1.a)ii) chegar ao Escritório Internacional em uma data em que já não possa mais sustar a publicação internacional do pedido internacional, o Escritório Internacional publicará prontamente na Gazeta uma nota reproduzindo a essência dessa notificação.

b) A essência de qualquer notificação a que ser referem as regras 29.2 e 51.4 será publicada na Gazeta e, caso a notificação chegue ao Escritório Internacional antes determinados os preparativos para a publicação da brochura, também nesta última.

c) Se o pedido internacional for retirado depois de sua publicação internacional, tal fato será publicado na Gazeta.

Regra 49

Línguas das traduções e montantes das taxas conforme o artigo 22.1)e 2)

49.1 Notificação

a) Qualquer Estado contratante que exija a remessa de uma tradução ou o pagamento de uma taxa nacional, ou ambos, conforme o artigo 22, deverá notificar ao Escritório Internacional:

I) as línguas de que exige uma tradução e a língua em que esta deverá ser feita;

II) o montante da taxa nacional.

b) Toda a notificação recebida pelo Escritório Internacional conforme a alínea a) será publicada prontamente na Gazeta pelo Escritório Internacional.

c) Se as exigências a que se refere a alínea $a$ ) forem posteriormente modificadas, essas modificações deverão ser comunicadas pelo Estado contratante ao Escritório Internacional que publicará prontamente a notificação na Gazeta. Se a modificação se referir à exigência de uma tradução para uma língua que não fora exigida antes dessa modificação, ela não se aplicará senão aos pedidos internacionais depositados mais de dois meses depois da publicação da notificação na Gazeta. De outro modo, a data efetiva de qualquer modificação será determinada pelo Estado contrantante.

\subsection{Línguas}

A língua em que uma tradução poderá ser exigida deverá ser uma língua oficial da Repartição designada. Caso haja várias línguas oficiais, nenhuma tradução poderá ser exigida se o pedido internacional estiver redigido em uma dessas línguas oficiais e se uma tradução tiver de ser fornecida, o depositante poderá escolher qualquer uma delas. Não obstante as disposições desta 
alínea, caso haja várias línguas oficiais, mas a legislação nacional determinar a utilização de uma dessas línguas pelos estrangeiros, uma tradução nessa língua poderá ser exigida.

49.3 Declarações a que se refere o artigo 19

Para as finalidades do artigo 22 e desta regra, qualquer declaração feita de acordo com o artigo 19.1 será considerada como parte integrante do pedido internacional.

\section{Regra 50}

Faculdade a que se refere o artigo 22.3)

50.1 Exercício da faculdade

a) Qualquer Estado contratante que conceda prazos que expirem depois dos previstos no artigo 22.1) ou 2) deverá notificar ao Escritório Internacional os prazos assim concedidos.

b) Toda notificação recebida pelo Escritório Internacional conforme a alínea $a$ ) será publicada prontamente na Gazeta pelo Escritório Internacional.

c) As notificações relativas à abreviação de um prazo previamente fixado aplicar-se-ão aos pedidos internacionais depositados depois de expirados três meses a contar da data em que a notificação foi publicada pelo Escritório Internacional.

d) As notificações relativas à prolongação de um prazo previamente fixado aplicar-se-ão, desde sua publicação ou depositados depois dessa data ou, se o Estado contratante que fez a notificação fixar uma data ulterior, nesta última.

\section{Regra 51}

Revisão por Repartições designadas

51.1 Prazo para apresentar o pedido de remessa de cópias

O prazo a que se refere o artigo 21.1)c) será de dois meses a contar da data da notificação enviada ao depositante conforme as regras 20.7.i), 24.2.b), 29.1.a)ii) ou 29.1.b).

\subsection{Cópia da notificação de constatação negativa}

Se, depois de haver recebido uma notificação de constatação negativa de acordo com artigo 11.1), o depositante solicitar ao Escritório Internacional, de acordo com o artigo 25.1, a remessa de cópias do processo do alegado pedido internacional a uma Repartição indicada por ele para ser designada, deverá juntar a esse pedido cópia da notificação a que se refere a regra 20.7.i).

51.3 Prazo para pagamento da taxa nacional e para remessa de uma tradução

O prazo a que se refere o artigo 25.20)a) expirará ao mesmo tempo que o prazo fixado na regra 51.1.

\subsection{Notificação ao Escritório Internacional}

Se, de acordo com o artigo 25.2, a Repartição designada competente decidir que a recusa, a declaração ou constatação a que se refere o artigo 25.1 não foram justificadas, notificará prontamente o Escritório Internacional de que considerará o pedido internacional como se nele não houvesse ocorrido o erro ou a omissão mencionados no artigo 25.2).

\section{Regra 52}

Emenda das reinvidicações, da descrição e dos desenhos junto às Repartições designadas

\subsection{Prazo}

a) Em todo o Estado designado em que o processo e o exame do pedido internacional sejam instaurados sem requerimento especial, o depositante, se o desejar, deverá exercer o direito que lhe 
é conferido pelo artigo 28 no prazo de um mês a contar do cumprimento das exigências contidas no artigo 22, desde que, se a comunicação a que se refere a regra 47.1 não tiver sido efetuada ao se expirar o prazo aplicável de acordo com o artigo 22, ele haja exercido esse direito antes de decorridos 4 meses da expiração dessa data. Em qualquer caso o depositante poderá exercer esse direito em qualquer data ulterior se a legislação nacional desse Estado o permitir.

b) Em todo o Estado designado em que a legislação nacional disponha que o exame não seja iniciado senão por requerimento especial, o prazo durante o qual, ou o momento em que o depositante poderá exercer o direito conferido pelo artigo 28 será o mesmo que o previsto pela legislação nacional para o depósito de emendas em caso do exame, por requerimento especial, de pedidos nacionais, desde que esse prazo não expire antes, ou que esse momento não ocorra antes da expiração da prazo aplicável conforme a alínea $a$ ).

\section{PARTE C}

\section{Regras Relativas ao Capítulo II do Tratado}

\section{Regra 53}

Pedido de exame preliminar internacional

\subsection{Formulário}

a) O pedido de exame preliminar internacional deverá ser feito em formulário impresso.

b) Exemplares do formulário impresso serão fornecidos gratuitamente aos depositantes pelas Repartições receptoras.

c) Os pormenores relativos ao formulário serão especificados nas Instruções Administrativas.

d) O pedido de exame preliminar internacional deverá ser apresentado e duas vias idênticas.

\subsection{Conteúdo}

a) O pedido de exame preliminar internacional deverá conter:

I) uma petição;

II) indicações referentes ao depositante e ao mandatário, caso haja um mandatário;

III) indicações referentes ao pedido internacional a que disser respeito;

IV) uma eleição de Estados.

b) O pedido de exame preliminar internacional deverá ser assinado.

\subsection{Petição}

O pedido deverá ser no teor, e ser redigido de preferência como segue: $<<$ Pedido de exame preliminar internacional de acordo com o artigo 31 do Tratado de Cooperação em Matéria de Patentes: O abaixo assinado solicita o pedido internacional discriminado abaixo seja objeto de um exame preliminar internacional conforme o Tratado de Cooperação em Matéria de Patentes>>.

\subsection{Depositante}

No que diz respeito à indicações relativas às regras 4.4 e 4.16; a regra 4.5 aplicar-se-á mutatis mutandis.

\subsection{Mandatário}

Caso haja designação de mandatário, aplicar-se-ão as regras 4.4, 4.7 e 4.16; a regra 4.8 aplicar-se-á mutatis mutandis. 


\subsection{Identificação do pedido internacional}

O pedido internacional deverá ser identificado pelo nome da Repartição receptora em que houver sido depositado, pelo nome e endereço do depositante, pelo título da invenção e, quando o depositante conhecer a data do depósito internacional e o número do pedido internacional, por essa data e esse número.

\subsection{Eleição de Estados}

No pedido de exame preliminar internacional, pelo menos um Estado contratante obrigado pelo Capítulo II do Tratado deverá ser mencionado dentre os Estados designados como o Estado eleito.

\subsection{Assinatura}

O pedido de exame preliminar internacional deverá ser assinado pelo depositante.

\section{Regra 54}

Depositante autorizado a apresentar um pedido de exame preliminar internacional

\subsection{Domicílio e nacionalidade}

O domicílio e a nacionalidade do depositante, para fins do artigo 31.2), serão determinados conforme disposto nas regras 18.1 e 18.2.

\subsection{Vários depositantes: os mesmos para todos os Estados eleitos}

Se todos os depositantes forem depositantes para todos os Estados eleitos, o direito de apresentar um pedido de exame preliminar internacional conforme o artigo 31.2) existirá caso pelo menos um dentre eles seja:

I) domiciliado em ou nacional de um Estado contratante obrigado pelo Capítulo II e o pedido internacional haja sido depositado em obediência ao artigo 31.2)a) ou

II) uma pessoa autorizada a depositar um pedido de acordo com o artigo 31.2)b) e o pedido internacional haja sido depositado em obediência a uma decisão da Assembléia.

\subsection{Vários depositantes: diferentes para Estados eleitos diferentes}

a) Depositantes diferentes poderão ser indicados, para Estados ileitos diferentes desde que, em relação a cada Estado eleito, pelo menos um dos depositantes indicados para esse Estado seja:

I) domiciliado em ou nacional de um Estado contratante obrigado pelo Capítulo II e o pedido internacional haja sido depositado de acordo com o artigo 31.2)a) ou

II) uma pessoa autorizada a depositar um pedido de acordo com o artigo 31.2)b) e o pedido internacional haja sido depositado por decisão da Assembléia.

b) Se a condição estabelecida na alínea $a$ ) não houver sido preenchida em relação a determinado Estado eleito, a eleição desse Estado será considerada como não tendo sido feita.

54.4 Troca de pessoa ou do nome do depositante

Qualquer troca da pessoa ou do nome do depositante será, a pedido do depositante ou da Repartição receptora, registrado pelo Escritório Internacional que o notificará à Administração interessada encarregada do exame preliminar internacional e às Repartições eleitas.

\section{Regra 55}

Línguas (exame preliminar internacional) 


\subsection{Pedido de exame preliminar internacional}

O pedido de exame preliminar internacional deverá ser apresentado na língua do pedido internacional ou, quando for exigida uma tradução de acordo com a regra 55.2, na língua dessa tradução.

\subsection{Pedido internacional}

a) Se a Administração competente encarregada do exame preliminar internacional não fizer parte da mesma Repartição nacional ou da mesma organização intergovernamental que a Administração competente encarregada da pesquisa internacional, e se o pedido internacional for depositado em uma língua diferente da que foi mencionada - ou das que foram mencionadas - no acordo concluído entre o Escritório Internacional e a Administração encarregada do exame preliminar internacional, esta última poderá exigir que o depositante lhe submeta uma tradução do pedido internacional.

b) A tradução deverá ser submetida o mais tardar na última das duas datas seguintes:

I) data da expiração do prazo estabelecido na regra 46.1;

II) data de apresentação do pedido de exame preliminar internacional.

c) A tradução deverá conter uma declaração do depositante no sentido de que, tanto quanto seja do seu conhecimento, ela está completa e fiel. Essa declaração deverá ser assinada pelo depositante.

d) Se as disposições das alíneas $b$ ) e $c$ ) não houverem sido obedecidas, a Administração encarregada do exame preliminar no prazo de um mês a contar da data da solicitação. Caso o depositante não atenda a essa solicitação, o pedido será considerado como não tendo sido apresentado e a Administração encarregada do exame preliminar internacional comunicará esse fato ao depositante e ao Escritório Internacional.

\section{Regra 56}

\section{Eleições ulteriores}

56.1 Eleições apresentadas depois do pedido de exame preliminar internacional

A eleição de Estados não mencionados no pedido de exame preliminar internacional deverá ser efetuada por meio de uma nota assinada e apresentada pelo depositante e deverá identificar o pedido internacional e o pedido de exame preliminar internacional.

56.2 Identificação do pedido internacional

O pedido internacional deverá ser identificado conforme o disposto na regra 53.6.

56.3 Identificação do pedido de exame preliminar internacional

O pedido de exame preliminar internacional deverá ser identificado pela data em que foi apresentado e pelo nome da Administração encarregada do exame preliminar internacional à qual foi apresentado.

\subsection{Forma das eleições ulteriores}

A eleição ulterior deverá ser feita de preferência em um formulário impresso remetido gratuitamente aos depositantes. Se não for feita em tal formulário, deverá ser redigida de preferência como segue: <<Em relação ao pedido internacional depositado na ..., em..., sob $n^{0}$..., por ... (depositante) (e pedido de exame preliminar apresentado em ..., a...), o abaixo assinado elege o Estado (os Estados) adicional(s) seguinte(s) conforme disposto no artigo 31 do Tratado de Cooperação em Matéria de Patentes: ...>>.

56.5 Língua da eleição ulterior

A eleição ulterior deverá ser efetuada na mesma língua, do pedido de exame preliminar internacional. 


\section{Regra 57}

Taxa de execução

\subsection{Obrigação de pagar}

Qualquer pedido de exame preliminar internacional será sujeito ao pagamento de uma taxa em benefício do Escritório Internacional (<<taxa de execução >>).

\subsection{Montante}

a) O montante da taxa de execução será de 14 dólares dos Estados Unidos ou 60 francos suíços multiplicados pelo número das línguas em que o relatório de exame preliminar internacional tiver de ser traduzido, em obediência ao artigo 36.2), pelo Escritório Internacional.

b) Quando, em virtude de uma eleição ou eleições ulteriores, o relatório de exame preliminar internacional tiver de ser traduzido, em obediência ao artigo 36.2), pelo Escritório Internacional em uma ou várias línguas adicionais, um suplemento à taxa de execução, no montante de 14 dólares dos Estados Unidos ou 60 francos suíços por língua adicional, deverá ser pago.

\subsection{Modo e data de pagamento}

a) Com ressalva da alínea $b$ ), a taxa de execução será cobrada pela Administração encarregada do exame preliminar internacional à qual for apresentado o pedido de exame preliminar internacional e será devida na data de apresentação desse pedido.

b) Qualquer suplemento à taxa de execução de acordo com a regra 57.2.b) será cobrado pelo Escritório Internacional e devido na data da apresentação da eleição ulterior.

c) A taxa de execução deverá ser paga na moeda determinada pela Administração encarregada do exame preliminar internacional à qual o pedido de exame preliminar internacional (for apresentado, ficando entendido que, na ocasião de sua transferência para o Escritório Internacional por essa Administração, ela deverá ser livremente conversível em moeda suíça.

d) Qualquer suplemento à taxa de execução deverá ser pago em moeda suíça.

57.4 Falta de pagamento (taxa de execução)

a) Quando a taxa de execução deixar de ser paga como prescrito nas regras 57.2.a) e 57.3.a) e c), a Administração encarregada do exame preliminar internacional solicitará ao depositante que pague essa taxa no prazo de um mês a contar da data da solicitação.

b) Se o depositante atender à solicitação dentro do prazo prescrito, o pedido de exame preliminar internacional será considerado como tendo sido recebido na data em que a Administração encarregada do exame preliminar receber a taxa, a menos que, em virtude da regra 60.1.b) uma data ulterior seja aplicável.

c) Se o depositante não atender à solicitação dentro do prazo prescrito, o pedido de exame preliminar internacional será considerado como não tendo sido apresentado.

57.5 Falta de pagamento (suplemento à taxa de execução)

a) Quando o suplemento à taxa de execução não for pago de acordo com as regras 57.2.b) e 57.3.b) e d), o Escritório Internacional solicitará ao depositante que pague o suplemento dentro do prazo de um mês a contar da data dessa solicitação.

b) Se o depositante atender a essa solicitação dentro do prazo prescrito, a eleição ulterior será considerada como tendo sido feita na data de recebimento do suplemento pelo Escritório Internacional, salvo se uma data ulterior for aplicável, de acordo com a regra 60.2.b).

c) Se o depositante não atender à solicitação dentro do prazo prescrito, a eleição ulterior será considerada como não tendo sido apresentada. 


\subsection{Reembolso}

A taxa de execução, assim como qualquer suplemento a essa taxa, não será reembolsada em nenhuma circunstância.

\section{Regra 58}

Taxa de exame preliminar

\subsection{Direito de solicitar uma taxa}

a) Cada Administração encarregada do exame preliminar internacional poderá solicitar ao depositante que lhe pague uma taxa para execução do exame preliminar internacional $(<<$ taxa de exame preliminar $>>$ ) e para a realização de todas as demais tarefas confiadas às Administrações encarregadas do exame preliminar internacional pelo Tratado e pelo presente Regulamento de execução.

b) O montante da taxa de exame preliminar e a data em que ela será devida, quando for o caso, serão fixados pela Administração encarregada do exame preliminar internacional, contanto que essa data não seja anterior à data em que será devida a taxa de execução.

c) A taxa de exame preliminar internacional deverá ser paga diretamente à Administração encarregada do exame internacional. Quando essa Administração for uma Repartição nacional, a taxa será paga na moeda determinada por essa Repartição, e quando a Administração for uma organização intergovernamental, na moeda do Estado em que estiver sediada a organização intergovernamental ou em outra moeda livremente conversível na moeda do dito Estado.

\section{Regra 59}

Administração competente encarregada do exame preliminar internacional

59.1 Pedidos de exame preliminar internacional feitos de acordo com o artigo 31.2)a)

Em relação aos pedidos de exame preliminar internacional feitos de acordo com o artigo 31.2)a), cada Estado contratante obrigado pelas disposições do Capítulo II e de acordo com os termos do acordo aplicável a que se refere o artigo 32.2) e 3), comunicará a Escritório Internacional que Administração ou Administrações encarregadas do exame preliminar internacional serão competentes para proceder ao exame preliminar internacional dos pedidos internacionais depositados em sua Repartição nacional ou, no caso a que se refere a regra 19.1.b), na Repartição nacional de um outro Estado ou na organização intergovernamental agindo em nome de sua própria Repartição nacional; o Escritório Internacional publicará prontamente essa informação.

Quando várias Administrações encarregadas do exame preliminar internacional forem competentes, as disposições da regra 35.2. aplica-se-ão mutatismutandis.

59.2 Pedidos de exame preliminar internacional feitos de acordo com o artigo 31.2)b)

Quanto aos pedidos de exame preliminar internacional feitos de acordo com o artigo 31.2)b), a Assembléia, ao especificar a Administração encarregada do exame preliminar internacional com competência para os pedidos internacionais depositados em uma Repartição nacional que seja ela própria uma Administração encarregada do exame preliminar, dará preferência a essa Administração; se a Repartição nacional não for ela própria uma Administração encarregada do exame preliminar internacional, a Assembléia dará preferência à Administração encarregada do exame preliminar internacional recomendada por essa Repartição.

\section{Regra 60}

Certas falhas no pedido de exame preliminar internacional ou nas eleições 
60.1 Falhas no pedido de exame preliminar internacional

a) Se o pedido de exame preliminar internacional não preencher as condições prescritas nas regras 53 e 55, a Administração encarregada do exame preliminar internacional solicitará ao depositante que corrija as falhas dentro do prazo de um mês a contar da data dessa solicitação.

b) Se o depositante atender à solicitação dentro do prazo prescrito, o pedido de exame preliminar internacional será considerado como se houvesse sido recebido na data do recebimento da correção pela Administração encarregada do exame preliminar internacional ou, quando a taxa de execução for recebida de acordo com a regra 57.4.b) em uma data ulterior, nesta data.

c) Se o depositante não atender à solicitação dentro do prazo prescrito, o pedido de exame preliminar internacional será considerado com não havendo sido apresentado.

d) Se a falha for constatada pelo Escritório Internacional, este chamará a atenção da Administração encarregada do exame preliminar internacional para essa falha; essa Administração procederá então da maneira estabelecida nas alíneas a) a $c$ ).

60.2 Falhas nas eleições ulteriores

a) Se a eleição ulterior não preencher as condições prescritas na regra 56, o Escritório Internacional solicitará ao depositante que corrija as falhas dentro do prazo de um mês a contar da data dessa solicitação.

b) Se o depositante atender à solicitação dentro do prazo prescrito, a eleição ulterior será considerada como havendo sido recebida na data de recebimento da correção pelo Escritório Internacional ou, quando o suplemento à taxa de execução for recebido de acordo com a regra 57.5.b) em uma data ulterior, nesta data.

c) Se o depositante não atender à solicitação dentro do prazo prescrito, a eleição ulterior será considerada como não havendo sido apresentada.

60.3 Tentativas de eleições

Se o depositante houver tentado eleger um Estado que não seja um Estado designado ou um Estado que não esteja obrigado pelo Capítulo II, a tentativa de eleição será considerada como não havendo sido efetuada e o Escritório Internacional comunicará esse fato ao depositante.

Regra 61

Notificação do pedido de exame preliminar internacional e das eleições

61.1 Notificações ao Escritório Internacional, ao depositante e à Administração encarregada do exame preliminar internacional

a) A Administração encarregada do exame preliminar internacional indicará, nas duas vias do pedido de exame preliminar internacional, a data de recebimento ou, se for o caso, a data mencionada na regra 60.1.b).

A Administração encarregada do exame preliminar internacional enviará prontamente a via original ao Escritório Internacional. A outra via, ela conservará em seus arquivos.

b) A Administração encarregada do exame preliminar internacional informará prontamente, por escrito, ao depositante, a data do recebimento do pedido de exame preliminar internacional. Quando o pedido de exame preliminar internacional houver sido considerado, de acordo com as regras 57.4.c) ou 60.1.c), como não tendo sido apresentado, essa Administração comunicará este fato ao depositante.

c) O Escritório Internacional comunicará sem demora à Administração encarregada do exame preliminar internacional e ao depositante o recebimento e a data de recebimento de qualquer eleição ulterior. Essa data deverá ser a data efetiva de recebimento pelo Escritório Internacional ou, se for o caso, a data mencionada na regra 60.2.b). Quando a eleição ulterior houver sido 
considerada, de acordo com as regras 57.5.c) ou 60.2.c), como não tendo sido apresentada, o Escritório Internacional comunicará este fato ao depositante.

61.2 Notificações às Repartições eleitas

a) A notificação a que se refere o artigo 31.7) será feita pelo Escritório Internacional.

b) Essa notificação deverá indicar o número e a data do depósito do pedido internacional, o nome do depositante, o nome da Repartição receptora, a data do depósito do pedido nacional ou internacional cuja prioridade houver sido reivindicada (quando existir reivindicação de prioridade), a data de recebimento do pedido de exame preliminar internacional pela Administração encarregada do exame preliminar internacional e - em caso de eleição ulterior - a data de recebimento da eleição ulterior pelo Escritório Internacional.

c) A notificação deverá ser endereçada à Repartição eleita logo depois de expirado o $18^{\circ}$ mês a contar da data de prioridade ou, se o relatório de exame preliminar internacional for comunicado antes, na ocasião da comunicação desse relatório. As eleições efectuadas depois de uma tal notificação serão prontamente notificadas após sua apresentação.

\subsection{Informação ao depositante}

O Escritório Internacional informará ao depositante, por escrito, que fez a notificação a que se refere a regra 61.2, indicando-lhe a mesmo tempo, em relação a cada Estado eleito, qualquer prazo aplicável de acordo com o artigo 39.1)b).

Regra 62

Cópia para a Administração encarregada do exame preliminar internacional

62.1 Pedido internacional

a) Quando a Administração competente encarregada do exame preliminar internacional pertencer à mesma Repartição nacional ou à mesma organização intergovernamental que a Administração competente encarregada de pesquisa internacional, o mesmo processo servirá para os fins da pesquisa internacional e do exame preliminar internacional.

b) Quando a Administração competente encarregada da pesquisa internacional não pertencer à mesma Repartição nacional ou a mesma organização intergovernamental que a Administração competente encarregada do exame preliminar internacional, o Ecritório Internacional, prontamente após recebimento do relatório de pesquisa internacional ou, se o pedido de exame preliminar internacional hover sido recebido depois do relatório de pesquisa internacional, prontamente após recebimento do pedido de exame preliminar internacional, enviará uma cópia do pedido internacional e do relatório de pesquisa internacional à Administração encarregada do exame preliminar internacional. Quando, em lugar do relatório de pesquisa internacional, hover sido feita uma declaração de acordo com o artigo 17.2)a), as referências ao relatório de pesquisa internacional constantes da frase precedente deverão ser consideradas como referências a uma tal declaração.

\subsection{Emendas}

a) Qualquer emenda depositada de acordo com o artigo 19 será transmitida prontamente pelo Escritório Internacional à Administração encarregada do exame preliminar internacional. Se, na ocasião do depósito de tais emendas, um pedido de exame preliminar internacional já houver sido apresentado, o depositante, na ocasião do depósito das emendas nesse Escritório Intenacional, deverá também depositar um cópia dessas emendas na Administração encarregada do exame preliminar internacional.

b) Se o prazo previsto para o depósito das emendas no artigo 19 (vide regra 46.1) houver expirado sem que o depositante tenha depositado ou tenha declarado não desejar depositar emendas de acordo com esse artigo, o Escritório Internacional notificará o fato à Administração encarregada do exame preliminar internacional. 


\section{Regra 63}

Exigências mínimas para as Administrações encarregadas do exame preliminar internacional

63.1 Definição das exigências mínimas

As exigências mínimas a que se refere o artigo 32.3), serão as seguintes:

I) a Repartição nacional ou a organização intergovernamental deverá possuir pelo menos 100 funcionários de tempo integral dotados de habilitação técnica suficiente para realizar os exames;

II) essa Repartição ou essa organização deverá possuir pelo menos a documentação mínima a que se refere a regra 34 adequadamente adaptada às finalidades do exame;

III) essa Repartição ou essa oganização deverá possuir pessoal capaz de realizar o exame nos ramos que o mesmo abranger e dispondo dos conhecimentos linguísticos necessários à compreensão pelo menos das línguas em que a documentação mínima mencionada na regra 34 estiver redigida ou traduzida.

\section{Regra 64}

Estado da técnica para efeito do exame preliminar internacional

\subsection{Estado da técnica}

a) Para os fins do artigo 33.2) e 3), tudo quanto foi tornado acessível ao público em todos os recantos do mundo por divulgação escrita (inclusive desenhos e outras ilustrações), desde que esta locação à disposição do público haja ocorrido antes da data pertinente, será considerado como estado da técnica.

b) Para os fins da alíne $a$ ), a data pertinente será:

I) com ressalva da alínea $a$ ), a data do depósito internacional do pedido internacional que constituir o objeto do exame preliminar internacional.

II) quando o pedido internacional que constituir o objeto do exame preliminar intenacional reivindicar de maneira hábil a prioridade de um pedido anterior, a data do depósito desse pedido anterior.

\subsection{Divulgações não-escritas}

Nos casos em que a colocação à disposição do público houver ocorrido por meio de uma divulgação oral, de uma utilização, de uma exposição ou outro meio não-escrito ( $<<$ divulgação não-escrita $>>$ ) antes da data pertinente tal como definida na regra 64.1.b) e em que a data dessa divulgação não-escrita estiver indicada em uma divulgação escrita que foi tornada acessível ao público depois da data pertinente, a divulgação não-escrita não será considerada como integrando o estado da técnica para os fins do artigo 33.2) e 3). Todavia, o relatório de exame preliminar internacional deverá chamar atenção para uma tal divulgação não-escrita na forma estabelecida na regra 70.9 .

\subsection{Certos documentos publicados}

Quando um pedido ou uma patente, que constituiriam parte integrante do estado da técnica para os fins do artigo 33.2) e 3) caso houvessem sido publicados antes da data pertinente mencionada na regra 64.1, houverem sido publicados como tal depois da data pertinente mas depositados antes da data pertinente ou houverem reivindicado a prioridade de um pedido anterior, depositado antes da data pertinente, esse pedido ou essa patente publicados não serão considerados como constituindo parte integrante do estado da técnica para os fins do artigo 33.2) e 3). Entretanto, o relatório de exame preliminar internacional deverá chamar atenção para um tal pedido ou patente na forma prevista na regra 70.10. 
Regra 65

Atividade inventiva ou não-evidência

65.1 Relação com o estado da técnica

Para os fins do artigo 33.3), o exame preliminar internacional deverá levar em consideração a relação existente entre uma determinada reivindicação e o estado da técnica em seu conjunto. Deverá levar em consideração não só a relação existente entre a reivindicação e os documentos individuais ou as partes de tais documentos considerados individualmente, mas igualmente a relação existente entre a reivindicação e as combinações de tais documentos ou partes de documentos, quando tais combinações forem evidentes para um técnico no assunto.

\subsection{Data Pertinente}

Para as fins do artigo 33.3), a data pertinente para o estudo da atividade inventiva (não-evidência) será a data prescrita na regra 64.1.

Regra 66

Processamento na Administração do Exame Preliminar Internacional

66.1 Base do exame preliminar internacional

Antes de ser iniciado o exame preliminar internacional, o depositante poderá fazer emendas de acordo com o artigo 34.2)b); o exame preliminar internacional abrangerá inicialmente as reivindicações, a descrição e os desenhos tal como contidos no pedido internacional na ocasião em que tiver início o exame preliminar internacional.

66.2 Primeiro parecer escrito da Administração encarregada do exame preliminar internacional.

a) Se a Administração encarregada do exame preliminar internacional:

I) for de parecer que o pedido internacional contém qualquer das falhas descritas no artigo 34.4);

II) for de parecer que o relatório de exame preliminar internacional deveria ser negativo em relação a qualquer uma das reivindicações em virtude do fato de que a invenção nele reivindicada não pareça ser nova, não pareça envolver uma atividade inventiva (não pareça ser não-evidente), ou não pareça suscetível de aplicação industrial;

III) constatar qualquer falha na forma ou no conteúdo do pedido internacional de acordo com o Tratado ou presente Regulamento de execução;

IV) considerar que qualquer emenda vai além da exposição contida no pedido internacional, tal como depositada; ou

V) desejar juntar ao relatório de exame preliminar internacional observações relativas à clareza das reivindicações, da descrição e dos desenhos ou à questão de saber se as reivindicações baseiam-se inteiramente na descrição;

a) dita Administração o notificará por escrito ao depositante.

b) A notificação deverá expor, de forma pormenorizada, os motivos do parecer da Administração encarregada do exame preliminar internacional.

c) A notificação deverá solicitar ao depositante que apresente uma resposta escrita acompanhada, quando for o caso, por emendas ou correções.

d) A notificação deverá fixar um prazo para resposta. Esse prazo deverá ser razoável, levando em conta as circunstâncias. Deverá ser normalmente de dois meses a contar da data da notificação. Não deverá em hipótese alguma ser inferior a um mês a contar dessa data. Deverá ser de pelo menos dois meses a contar dessa data, quando o relatório de pesquisa internacional for transmitido ao 
mesmo tempo que a notificação. Não deverá em hipótese alguma ser superior a três meses a contar da data em questão.

66.3 Resposta formal à Administração encarregada do exame preliminar internacional

a) O depositante poderá responder à solicitação da Administração encarregada do exame preliminar internacional, mencionada na regra 66.2.c), efetuando emendas ou correções ou - caso discorde do parecer essa Administração - apresentado argumentos, conforme o caso, ou por ambos os meios.

b) Qualquer resposta deverá ser apresentada diretamente à Administração encarregada do exame preliminar internacional.

66.4 Possibilidade adicional de emendar ou corrigir

a) Se a Administração encarregada do exame preliminar internacional desejar emitir um ou vários pareceres escritos adicionais, poderá fazê-lo, invocando as regras 66.2 e 3.

b) A pedido do depositante, a Administração encarregada do exame preliminar internacional poderá oferecer-lhe uma ou várias possibilidades adicionais de apresentar emendas ou correções.

66.5 Emendas

Qualquer alteração além da retificação de erros evidentes de transcrição, nas reivindicações, na descrição ou nos desenhos, inclusive qualquer supressão de reivindicações, qualquer omissão de passagens da descrição, ou qualquer omissão, de certos desenhos, será considerada como uma emenda.

66.6 Comunicações informais com o depositante

A Administração encarregada do exame preliminar internacional poderá, a qualquer tempo, comunicar-se de maneira informal com o depositante por telefone, por escrito, ou por meio de entrevistas.

A dita Administração decidirá, a seu critério, se deseja conceder mais de uma entrevista quando o depositante o solicitar, ou se deseja responder a uma comunicação escrita informal do depositante.

66.7 Documentos de prioridade

a) Se a Administração encarregada do exame preliminar internacional necessitar de uma cópia do pedido cuja prioridade for reivindicada no pedido internacional, o Escritório internacional lhe enviará prontamente, a pedido, uma tal cópia, desde que, se o pedido for apresentado antes do Escritório Internacional haver recebido o documento de prioridade de acordo com a regra 17.1a), o depositante remeta a dita cópia, a sua escolha, ao Escritório internacional ou diretamente à Administração encarregada do exame preliminar internacional.

b) Se o pedido cuja prioridade for reivindicada estiver redigido em uma língua diferente da língua ou de uma das línguas da Administração encarregada do exame preliminar internacional, o depositante lhe remeterá, por solicitação, uma tradução na dita língua, ou numa das ditas línguas.

c) A cópia que o depositante deverá remeter, de acordo com a alínea $a$ ) e a tradução a que se refere a alínea $b$ ), deverá ser remetidas o mais tardar ao se expirar um prazo de dois meses a contar da data do pedido ou da solicitação. Se elas não fores remetidas dentro desse prazo, o relatório de exame preliminar internacional será feito como se a prioridade não houvesse sido reivindicada.

66.8 Formas das correções e das emendas

a) O depositante será solicitado a fornecer uma folha de substituição para cada folha do pedido internacional que, devido a uma correção ou emenda, divirja da folha originalmente depositada. A carta que acompanhar as folhas de substituição deverá chamar atenção para as divergências entre as folhas substituídas e as folhas de substituição. Se a emenda resultar na supressão de uma folha inteira essa emenda deverá ser comunicada em uma carta. 
b) A Administração encarregada do exame preliminar internacional aporá em cada folha de substituição, o número do pedido internacional, a data em que foi recebida e o carimbo de identificação dessa Administração. Conservará em seus arquivos qualquer folha de substituição, a carta que acompanhar a folha ou folhas de substituição e qualquer carta mencionada na última frase da alínea $a$ ).

\section{Regra 67}

Matéria a que se refere o artigo 34.4)a)i)

\subsection{Definição}

Nenhuma Administração encarregada do exame preliminar internacional será obrigada a realizar um exame preliminar internacional de um pedido internacional cuja matéria e na medida em que a matéria seja uma das seguintes:

I) teorias científicas e matemáticas;

II) variedades vegetais, raças animais, processos essencialmente biológicos de produção de vegetais e animais que não os processos microbiológicos e os produtos obtidos através desses processos;

III) planos, princípios ou métodos para a realização de negócios, de ações puramente intelectuais ou de jogos;

IV) métodos de tratamento do corpo humano ao animal pela cirurgia ou a terapia, assim como métodos de diagnóstico;

V) meras apresentações de informações;

VI) programas de computadores na medida em que a Administração encarregada do exame preliminar internacional estiver desaparelhada para proceder a um exame preliminar internacional de tais programas.

\section{Regra 68}

Falta de unidade de invenção (exame preliminar internacional)

\subsection{Ausência de solicitação de pagamento}

Se a Administração encarregada do exame preliminar internacional for de parecer que a exigência de uma unidade da invenção não for satisfeita e decidir não solicitar que o depositante limite as reivindicações ou pague taxas adicionais, ela fará o relatório de exame preliminar internacional, com ressalva do artigo 34.4)b), em relação ao pedido internacional completo, indicando, porém, nesse relatório, que, em sua opinião, ele não satisfaz a exigência de unidade da invenção, especificando os motivos de sua opinião.

\subsection{Solicitação de limitação ou de pagamento}

Se a Administração encarregada do exame preliminar internacional for de parecer que o pedido não satisfaz a exigência de unidade de invenção e decidir solicitar que o depositante, a sua escolha, limite as reivindicações ou pague taxas adicionais, indicará pelo menos uma possibilidade de limitação que, em sua opinião, satisfaz a exigência aplicável e especificará o montante das taxas adicionais e os motivos pelos quais considera que o pedido internacional não satisfaz a exigência de unidade de invenção. Fixará ao mesmo tempo um prazo, que leve em consideração as circunstâncias do caso, para que seja atendida essa solicitação; tal prazo não poderá ser inferior a um mês nem superior a dois meses a contar da data da solicitação. 


\subsection{Taxa adicional}

a) O montante da taxa adicional para o exame preliminar internacional a que se refere o artigo 34.3)a), será determinado pela Administração competente encarregada do exame preliminar internacional.

b) A taxa adicional para o exame preliminar internacional, a que se refere o artigo 34.3)a), deverá ser paga diretamente à Administração encarregada do exame preliminar internacional.

c) Qualquer depositante poderá pagar a taxa adicional sob protesto, isto é, juntando uma declaração fundamentada tendente a demonstrar que o pedido internacional preencha a condição de unidade de invenção ou que o montante da taxa adicional exigida e excessivo. Uma comissão de três membros ou qualquer outra instância especial da Administração encarregada do exame preliminar internacional, ou qualquer autoridade superior competente, examinará o protesto e, na medida em que julgar justificado, ordenará o reembolso, total ou parcial, da taxa adicional ao depositante. A pedido deste último, o texto de seu protesto bem como o da decisão serão comunicadas às Repartições eleitas, na forma de anexo ao relatório de exame preliminar internacional.

d) A comissão de três membros, a instância especial ou a autoridade superior competente a que se refere a alínea $c$ ) não deverá incluir qualquer pessoa que haja participado da decisão, objeto do protesto.

\subsection{Procedimento no caso de limitação insuficiente das reivindicações}

Se o depositante limitar as reivindicações, porém de forma insuficiente a satisfazer as exigências de unidade da invenção, a Administração encarregada do exame preliminar internacional procederá de maneira prevista no artigo 34.3)c.

\subsection{Invenção principal}

Em caso de dúvida quanto à questão de saber qual é a invenção principal para os fins do artigo 34.3)c), a invenção mencionada em primeiro lugar nas reivindicações será considerada como a invenção principal.

Regra 69

Prazo para o exame preliminar internacional

\subsection{Prazo para o exame preliminar internacional}

a) Todos os acordos concluídos com Administrações encarregadas do exame preliminar internacional estabelecerão o mesmo prazo para a elaboração do relatório de exame internacional. Esse prazo não deverá exceder:

I) 6 meses a partir do início do exame preliminar internacional;

II) quando a Administração encarregada do exame preliminar internacional houver enviado uma solicitação de limitação das reivindicações ou de pagamento das taxas adicionais (artigo 34.3), 8 meses a partir do início do exame preliminar internacional.

b) O exame preliminar internacional será instaurado tão logo a Administração encarregada do exame preliminar internacional receba:

I) de acordo com a regra 62.2 a), as reivindicações tal como emendadas em virtude do artigo 19; ou

II) de acordo com a regra 62.2b), uma notificação do Escritório Internacional no sentido de que nenhuma emenda decorrente de disposição do artigo 19 foi depositada dentro do prazo determinado ou de que o depositante declarou não desejar fazer tais emendas; ou

III) quando o relatório de pesquisa internacional estiver em poder da Administração encarregada do exame preliminar internacional, uma notificação do depositante manifestando o desejo de que o 
exame preliminar internacional seja iniciado e vise as reivindicações tal como forma especificadas nessa notificação; ou

IV) uma notificação da declaração da Administração encarregada da pesquisa internacional de que não será feito qualquer relatório de pesquisa internacional (artigo 17.2)a).

c) Se a Administração competente encarregada do exame preliminar internacional pertencer à mesma Repartição nacional ou à mesma organização intergovernamental que a Administração encarregada da pesquisa internacional, o exame preliminar internacional poderá, caso a Administração encarregada do exame preliminar o desejar, ser iniciado ao mesmo tempo que a pesquisa internacional. Nesse caso, o relatório de exame preliminar internacional deverá ser feito, não obstante as disposições da alínea $a$ ), o mais tardar 6 meses depois de expirado o prazo concedido, de acordo com o artigo 19, para a modificação das reivindicações.

\section{Regra 70}

Relatório de exame preliminar internacional

\subsection{Definição}

No sentido desta regra, por <<relatório $>>$ deverá ser compreendido o relatório de exame preliminar internacional.

\subsection{Base do relatório}

a) Se as reivindicações houverem sido emendadas, o relatório será elaborado à base das reivindicações tal como foram emendadas.

b) Se, de acordo com a regra 66.7c), o relatório houver sido elaborado como se a prioridade não houvesse sido reivindicada, o relatório deverá mencioná-lo.

c) Se a Administração encarregada do exame preliminar internacional julgar que qualquer emenda vai além da exposição do pedido internacional tal como foi depositado, o relatório será feito como se tal emenda não houvesse sido efetuada e o assinalará, assim como também explicará por que motivos julga que a emenda vai além da exposição em questão.

\subsection{Identificações}

O relatório identificará a Administração encarregada do exame preliminar internacional que o elaborou, indicando o nome dessa Administração, e identificará o pedido internacional, indicando o número desse pedido, o nome do depositante, o nome da Repartição receptora e a data do depósito internacional.

\subsection{Datas}

O relatório indicará:

I) a data em que o pedido de exame preliminar internacional foi apresentado; e

II) a data do relatório; esta deverá ser a data de conclusão do relatório.

\section{Classificação}

a) O relatório repetirá a classificação fornecida de acordo com a regra 43.3 se a Administração encarregada do exame preliminar internacional estiver de acordo com essa classificação.

b) Caso contrário, a Administração encarregada do exame preliminar internacional indicará no relatório a classificação, pelo menos segundo a Classificação Internacional das Patentes, que ela considerar correta. 
70.6 Declaração a que se refere o artigo 35.2)

a) A declaração mencionada no artigo 35.2) consistirá em um $<<\mathrm{SIM}>>$ ou $<<\mathrm{NÃO}>>$, ou um equivalente dessas palavras na língua do relatório ou um sinal apropriado especificado nas Instruções Administrativas, e será seguido das citações, explicações e observações, caso as haja, previstas na última frase do artigo 35.2).

b) Se não estiver conforme a qualquer um dos três critérios mencionados no artigo 35.2) (a saber, novidade, atividade inventiva (não-evidência), aplicação industrial) a declaração será negativa. Se nesse caso, qualquer um desses critérios, tomado separadamente, houver sido satisfeito, o relatório especificará o mesmo.

70.7 Citações que se refere o artigo 35.2)

a) O relatório citará os documentos considerados como aptos a apoiar as declarações feitas de acordo com o artigo 35.2).

b) As disposições da regra 43.5.b) e e) aplicar-se-ão também ao relatório.

70.8 Explicações a que se refere o artigo 35.2)

As Instruções Administrativas conterão princípios básicos para os casos em que as explicações mencionadas no artigo 35.2) devam ser ou não fornecidas, assim como para a forma dessas explicações. Esses princípios básicos deverão fundar-se nos critérios seguintes:

I) explicações deverão ser fornecidas cada vez que a declaração for negativa a respeito de qualquer reivindicação;

II) explicações deverão ser fornecidas cada vez que a declaração for positiva, salvo se os motivos que levaram à citação de um documento qualquer sejam fáceis de perceber através de consulta do documento citado;

III) em regra geral, deverão ser fornecidas explicações ao se tratar do caso previsto na última frase da regra $70.6 b$ )

\subsection{Divulgações não-escritas}

Qualquer divulgação não-escrita a que se refira o relatório em virtude da regra 64.2 será mencionada pela indicação do fato de que se trata de um tal tipo de divulgação, pela data em que a divulgação escrita referente à divulgação não-escrita foi tornada acessível ao público, e pela data em que a divulgação não-escrita foi feita publicamente.

70.10 Certos documentos publicados

Qualquer pedido ou patente publicado em virtude da regra 64.3, será mencionado como tal e seguido de uma indicação de sua data de publicação, de sua data de depósito ou de sua data de prioridade reivindicada (caso haja uma).

A respeito de qualquer data de prioridade reivindicada de qualquer desses documentos, o relatório poderá indicar que, no parecer da Administração encarregada do exame preliminar internacional, essa data não foi reivindicada de maneira válida.

70.11 Menção de emendas ou de correções de certas falhas

Se houverem sido feitas modificações ou correções junto à Administração encarregada do exame preliminar internacional, tal fato será especificado no relatório.

70.12 Menção de certos defeitos

Se a Administração encarregada do exame preliminar internacional for de parecer que na ocasião em que preparar o relatório: 
I) o pedido internacional contém qualquer uma das falhas mencionadas na regra 66.2.a)iii) fará constar esse parecer e os motivos relativos ao mesmo relatório;

II) o pedido internacional está sujeito a uma das observações mencionadas na regra 66.2.a)V), poderá fazer constar essa opinião no relatório e, caso o faça, os motivos relativos à mesma.

70.13 Observações relativas à unidade da invenção

Se o depositante houver pago taxas adicionais pelo exame preliminar internacional, ou se o pedido internacional ou o exame preliminar internacional houver sido limitado de acordo com o artigo 34.3), o relatório o indicará. Além disso, quando o exame preliminar internacional houver sido efetuado à base de reivindicações limitadas (artigo 34.3)a)) ou unicamente à base de invenção principal artigo 34.3)c), o relatório indicará que partes do pedido internacional constituiram o objeto do exame prelimiar internacional e que partes não o constituíram.

\subsection{Assinatura}

O relatório será assinado por um funcionário autorizado da Administração encarregada do exame preliminar internacional.

\subsection{Forma}

As condições materiais quanto à forma do relatório serão especificadas na Instruções Administrativas.

\subsection{Anexos ao relatório}

Se as reivindicações, a descrição ou os desenhos houverem sido emendados ou se qualquer parte do pedido internacional houver sido corrigida junto à Administração encarregada do exame preliminar internacional, cada folha de substituição anotada de acordo com a regra 66.8.b) será anexada ao relatório. As folhas de substituição substituídas por outras folhas de substituição posteriores não serão anexadas. Se a emenda for comunicada em carta, uma cópia desa carta será igualmente anexada ao relatório.

70.17 Língua do relatório e dos anexos

a) O relatório será elaborado na língua de publicação do pedido internacional a que disser respeito.

b) Qualquer anexo deverá ser apresentado na língua em que foi depositado o pedido internacional a que se referir e, caso seja diferente, também na língua em que foi publicado esse pedido internacional.

\section{Regra 71}

Transmissão do relatório de exame preliminar internacional

\subsection{Destinatários}

A Administração encarregada do exame preliminar internacional transmitirá, no mesmo dia, uma cópia do relatório de exame preliminar internacional e de seus anexos, se os houver, ao Escritório Internacional, e uma cópia ao depositante.

\subsection{Cópia de documentos citados}

a) O pedido a que se refere o artigo 36.4) poderá ser apresentado a qualquer momento durante 7 anos a partir da data de depósito do pedido internacional a que se refere o relatório.

b) A Administração encarregada do exame preliminar internacional poderá exigir que a parte (depositante ou Repartição eleita) que lhe apresentou o pedido, lhe pague as despesas de preparo e expedição das cópias. O montante dessas despesas será determinado nos acordos a que se refere o artigo 32.2) concluídos entre a Administração encarregada do exame preliminar internacional e o Escritório Internacional. 
c) Qualquer Administração encarregada do exame preliminar internacional que não deseje enviar cópias diretamente a nenhuma Repartição eleita enviará uma cópia ao Escritório Internacional que então procederá conforme estipulado nas alíneas $a$ ) e $b$ ).

d) Qualquer Administração encarregada do exame preliminar internacional poderá confiar as tarefas mencionadas nas alíneas $a$ ) a c) a outra organização responsável perante ela.

\section{Regra 72}

Tradução do relatório de exame preliminar internacional

\subsection{Línguas}

a) Qualquer Estado eleito poderá exigir que o relatório de exame preliminar internacional, elaborado em uma língua diferente da língua oficial ou de uma das línguas oficiais de sua Repartição nacional, seja traduzido para o alemão, o espanhol, o francês, o inglês, o japonês ou o russo.

b) Qualquer exigência desse gênero deverá ser notificada ao Escritório Internacional, que a publicará prontamente na Gazeta.

72.2 Cópias de traduções para o depositante

O Escritório Internacional transmitirá uma cópia de cada tradução do relatório de exame preliminar internacional ao depositante, na mesma ocasião em que comunicar essa tradução à ou às Repartições eleitas interessadas.

\subsection{Observações relativas à tradução}

O depositante poderá fazer observações, constitui erros de tradução contidos da tradução do relatório de exame preliminar internacional e deverá enviar uma cópia dessas observações a cada uma das Repartições eleitas interessadas e ao Escritório Internacional.

\section{Regra 73}

Comunicação do relatório de exame preliminar internacional

\subsection{Preparo de cópias}

O Escritório Internacional preparará as cópias dos documentos que deverão ser comunicados de acordo com o artigo 36.3)a).

\subsection{Prazo de comunicação}

A comunicação prevista no artigo 36.3)a) deverá ser feita tão rapidamente quanto possível.

\section{Regra 74}

Tradução e transmissão dos anexos ao relatório de exame preliminar internacional

\subsection{Prazo}

Qualquer folha de substituição a que se refere a regra 70.16 ou qualquer emenda mencionada na última frase dessa regra que houverem sido depositadas antes da remessa da tradução do pedido internacional exigida de acordo com o artigo 39, ou quanto a remessa dessa tradução for regida pelo artigo 64.2)a)I) e houver sido depositada antes da remessa da tradução do pedido internacional como prescrito no artigo 22, deverão ser traduzidas e transmitidas ao mesmo tempo que a remessa mencionada no artigo 39 ou, quanto aplicável, no artigo 22, ou se depositadas 1 mês antes dessa remessa ou 1 mês depois dessa remessa, deverão ser traduzidas e transmitidas um mês depois que houverem sido depositadas. 


\section{Regra 75}

Retirada do pedido internacional, do pedido de exame preliminar internacional ou de eleições

\subsection{Retiradas}

a) A retirada doo pedido internacional ou de todas as eleições poderá ser efetuada antes de expirado um prazo de 25 meses a contar da data de prioridade, exceto no caso de qualquer Estado eleito em que o processo ou exame nacional já tenham sido iniciados. A retirada da eleição de qualquer Estado eleito poderá ser efetuado na data em que forem iniciados nesse Estado o processo e o exame.

b) A retirada será efetuada por meio de uma nota assinada pelo depositante para o Escritório Internacional. No caso a que se refere a regra 4.8.b), a nota exigirá a assinatura de todos os depositantes.

\subsection{Notificação às Repartições eleitas}

a) O fato da retirada do pedido de exame preliminar internacional ou de todas as eleições será notificado prontamente pelo Escritório Internacional às Repartições nacionais de todos os Estados que, até o momento da retirada, eram Estados eleitos e tenham sido avisado de sua eleição.

b) $\mathrm{O}$ fato da retirada de uma eleição e a data do recebimento da retirada serão notificados prontamente pelo Escritório Internacional à Repartição eleita interessada, salvo se esta ainda não houver sido informada de sua eleição.

75.3 Notificação à Administração encarregada do exame preliminar internacional

O fato da retirada do pedido de exame preliminar internacional ou de todas as eleições será notificado prontamente pelo Escritório Internacional à Administração encarregada do exame preliminar internacional que esta última, no momento da retirada, houver sido informada da existência do pedido de exame preliminar internacional.

75.4 Faculdade concedida pelo artigo 37.4)b)

a) Qualquer Estado contratante que deseje invocar o beneficio da faculdade prevista no artigo 37.4)b) deverá notificar este fato por escrito ao Escritório Internacional.

b) A notificação a que se refere a alínea $a$ ) será publicada prontamente pelo escritório Internacional na Gazeta e aplicar-se-á aos pedidos internacionais depositados mais de um mês depois da data de publicação do exemplar que a publicou.

\section{Regra 76}

Línguas das traduções e montantes das taxas de acordo com artigo 39.1);

Tradução do documento de prioridade

76.1 Notificação

a) Qualquer Estado contratante que exija a remessa de uma tradução ou o pagamento de uma taxa nacional, ou ambos, de acordo com o artigo 39.1), deverá notificar ao Escritório Internacional:

I) as línguas das quais exige uma tradução e a língua em que esta deverá ser feita;

II) o montante da taxa nacional.

b) Qualquer notificação recebida pelo Escritório Internacional de acordo com a alínea $a$ ) será publicada pelo dito Escritório na Gazeta.

c) Se as exigências a que se refere a alínea $a$ ) forem mais tarde modificadas, essas modificações deverão ser notificadas pelo Estado contratante ao Escritório Internacional, e este último publicará 
sem demora a notificação na Gazeta. Se a modificação for no sentido de que uma tradução seja exigida em uma língua não exigida antes, essa modificação não terá efeito senão em relação aos pedidos de exame preliminar internacional apresentados mais de dois meses depois da publicação da notificação na Gazeta. De outro modo a data efetiva de qualquer modificação será determinada pelo Estado contratante.

\subsection{Línguas}

A língua em que uma tradução poderá ser exigida deverá ser uma língua oficial da Repartição eleita. Se houver várias línguas oficiais, nenhuma tradução poderá ser exigida se o pedido internacional estiver redigiso em uma delas. Se houver várias línguas oficiais e se uma tradução tiver de ser fornecida, o depositante poderá escolher qualquer uma dessas línguas. Não obstante as disposições precedentes nesta alínea, caso haja várias línguas oficiais, mas a legislação nacional determinar a utilização de uma dessas línguas pelos estrangeiros, uma tradução nessa língua poderá ser exigida.

\section{Regra 77}

Faculdade a que se refere o artigo 39.1)b)

\subsection{Exercício da faculdade}

a) Qualquer Estado contratante que conceda prazos que expirem depois do prazo previsto no artigo 39.1)a), deverá notificar ao Escritório Internacional os prazos assim concedidos.

b) Qualquer notificação recebida pelo Escritório Internacional de acordo com a alínea a) será publicada prontamente por esse Escritório na Gazeta.

c) As notificações relativas à abreviação de um prazo anteriormente fixado aplicar-se-ão aos pedidos de exame preliminar internacional apresentados depois de expirados três meses contados a partir da data de publicação da notificação pelo Escritório Internacional.

d) As notificações relativas à prolongação de um prazo anteriormente fixado terão efeito desde o momento da publicação pelo Escritório Internacional na Gazeta nos casos de pedidos de exame preliminar internacional em curso à data dessa publicação ou apresentados depois dessa data ou, se o Estado contratante que fizer a notificação fixar uma data ulterior, nesta última data.

Regra 78

Emenda das reivindicações, da descrição e dos desenhos

Junto às Repartições eleitas

78.1 Prazo, no caso da eleição ocorrer antes de expirados 19 meses a contar da data de prioridade

a) Quando a eleição de qualquer Estado contratante for realizada antes de expirados 19 meses a contar da data de prioridade, o depositante que desejar exercer o direito concedido pelo artigo 41 deverá fazê-lo depois da transmissão do relatório de exame preliminar internacional em obediência ao artigo 39, desde que, se a citada transmissão não houver sido efetuada ao se expirar o prazo a que se refere o artigo 39, ele exerça esse direito o mais tardar na data de expiração desse prazo. Em ambos os casos o depositante poderá exercer o direito em questão em qualquer outra data, se assim o permitir a legislação nacional do Estado em causa.

b) Em qualquer Estado eleito cuja legislação nacional disponha que o exame só tenha início depois de apresentado um requerimento especial, a legislação nacional poderá estabelecer que o prazo dentro do qual, ou a ocasião em que o depositante poderá exercer o direito a que se refere o artigo 41 - quando a eleição de qualquer Estado contratante ocorra antes da expiração do $19^{\circ}$ mês a contar da data de prioridade - seja o mesmo que aquele estabelecido pela legislação nacional para o depósito de emendas, no caso de exame, o requerimento especial, de pedidos nacionais, contanto que tal prazo não expire, ou tal ocasião não ocorra antes de esgotado o prazo a que se refere o artigo 39. 
78.2 Prazo, no caso da eleição ocorrer depois de expirados 19 meses a contar da data de prioridade

Quando a eleição de qualquer Estado contratante houver sido efetuada depois de expirado o $19^{\circ}$ mês a contar da data de prioridade e o depositante desejar apresentar emendas de acordo com o artigo 41, aplicar-se-á o prazo estabelecido no artigo 28 para a apresentação de emendas.

78.3 Modelos de utilidade

As disposições das regras 6.5 e 13.5 aplicar-se-ão, mutatis mutandis, perante as Repartições eleitas. Se a eleição houver ocorrido antes da expiração do $19^{\circ}$ mês a contar da data de prioridade, a referência ao prazo aplicável de acordo com o artigo 22 será substituída por uma referência ao prazo aplicável de acordo com o artigo 39.

\section{PARTE D}

Regras Relativas ao Capítulo III do tratado

Regra 79

Calendário

79.1 Expressão das datas

Os depositantes, as Repartições nacionais, as Repartições receptoras, as Administrações encarregadas da pesquisa internacional e o Escritório Internacional para os fins do Tratado e do presente regulamento, expressarão qualquer data segundo a era cristã e o calendário gregoriano; caso utilizem outras eras ou outros calendários, expressão igualmente todas as datas segundo a dita era ou o dito calendário.

Regra 80

Cálculo dos prazos

\subsection{Prazos expressos em anos}

Quando um prazo for expresso em um ano ou em um certo número de anos, terá início no dia em que o acontecimento em consideração ocorreu e expirará, no ano subsequente a ser considerado, no mês de mesmo nome e no dia de mesmo número que o mês e o dia que constituíram o ponto de partida desse prazo; entretanto, se o mês subsequente a ser levado em consideração não possuir dia com o mesmo número, o prazo considerado expirará no último dia desse mês.

\subsection{Prazos expressos em meses}

Quando um prazo for expresso em um mês ou em um certo número de meses, terá início no dia que o acontecimento ocorreu e expirará, no mês subsequente a ser considerado, no dia de mesmo número que o dia que constituiu o início do prazo; todavia, se o mês subsequente a ser levado em consideração não tiver dia com o mesmo número, o prazo considerado expirará no último dia desse mês.

\subsection{Prazos expressos em dias}

Quando um prazo for expresso em um certo número de dias, terá início no dia seguinte àquele em que o acontecimento considerado ocorreu e expirará no dia em que se atingir o último dia do cálculo.

80.4 Datas locais

a) A data a ser levada em consideração como início de um prazo será a data que prevaleceu na localidade no momento em que ocorreu o acontecimento em consideração. 
b) A data de expiração de um prazo será a data que prevalecer na localidade em que o documento exigido deverá ser depositado ou que a taxa exigida deverá ser paga.

80.5 Expiração em dia de descanso

Se qualquer prazo durante o qual um documento ou uma taxa tiver de chegar a uma Repartição nacional ou a uma organização intergovernamental expirar num dia em que essa Repartição ou essa organização não estiver aberta ao público para tratar de negócios oficiais, ou bem em um dia em que a correspondência postal comum não for distribuída na localidade em que essa Repartição ou essa organização estiver situada, o prazo terminará no dia seguinte ao qual nenhuma dessas duas circunstâncias existir mais.

80.6 Data de documentos

Quando um prazo tiver no dia da data de um documento ou de uma carta emanando de uma Repartição nacional ou de uma organização intergovernamental, qualquer parte interessada poderá provar que o dito documento ou a dita carta foi posta no correio num dia posterior a essa data, caso em que a data em que esse papel foi efetivamente despachado será a considerada, para efeito do cálculo do prazo, como a data que constitui o início desse prazo.

80.7 Fim de um dia útil

a) Um prazo que expire em um dia determinado expirará no momento em que a Repartição nacional ou a organização intergovernamental em que o documento deverá ser depositado ou em que a taxa deverá ser paga encerrar seu expediente nesse dia.

b) Qualquer Repartição ou qualquer organização poderá fugir às disposições da alínea $a$ ), prolongando o prazo até meia-noite, no dia em consideração.

c) O Escritório Internacional ficará aberto ao público até as 18 horas.

Regra 81

Modificação dos prazos fixados pelo Tratado

81.1 Propostas

a) Qualquer Estado contratante e o Diretor-Geral poderão propor modificações dos prazos de acordo com o artigo 47.2)

b) As propostas que emanem de um Estado contratante deverão ser apresentadas ao Diretor-Geral.

\subsection{Decisão pela Assembléia}

a) Quando a proposta for apresentada à Assembléia, seu texto será enviado pelo Diretor-Geral a todos os Estados contratantes pelo menos dois meses antes da sessão da Assembléia cuja ordem do dia inclua essa proposta.

b) Durante os debates pela Assembléia a proposta poderá ser emendada e emendas apresentadas em consequência.

c) A proposta será considerada como adotada se nenhum dos Estados Contratantes na hora da cotação votar contra a mesma.

81.3 Votos por correspondência

a) Quando o Processo de voto por correspondência for o escolhido, a proposta constará de uma comunicação escrita enviada pelo Diretor-Geral aos Estados contratantes, solicitando a estes últimos que expressem seu voto por escrito.

b) A solicitação fixará o prazo em que as respostas contendo os votos expressos por escrito deverão chegar ao Escritório Internacional. Esse prazo será de pelo menos três meses a contar da data da solicitação. 
c) As respostas deverão ser positivas ou negativas. As propostas de emendas ou meras observações não serão consideradas como votos.

d) A proposta será considerada como adotada se nenhum Estado contratante se opuser à emenda e se pelo menos a metade dos Estados contratantes expressar quer sua aprovação, quer sua indiferença, quer ainda sua abstenção.

Regra 82

Irregularidades no serviço postal

82.1 Atrasos ou perda da correspondência postal

a) Com ressalva das disposições da regra 22.3, qualquer parte interessada poderá tentar provar que despachou o documento ou a carta 5 dias antes da expiração do prazo. Exceto quando a correspondência por via terrestre ou marítima chegar normalmente ao seu destino dentro dos dois dias seguintes à sua entrega na agência postal, ou quando não houver correio, tal prova só poderá ser fornecida se a expedição houver sido feita por via aérea. De qualquer maneira, só poderá ser feita prova se a correspondência houver sido registrada pelas autoridades postais.

b) Se ficar provado a contento da Repartição nacional ou da organização intergovernamental destinatária que a expedição foi feita como indicada acima, o atraso na chegada será desculpado ou, se o documento ou a carta se perderem, sua substituição por uma nova via será autorizada, desde que a parte interessada prove a contento da dita Repartição ou da dita organização que o documento ou a carta remetidos em substituição são idênticos ao documento perdido ou à carta perdida.

c) Nos casos a que se refere a alínea $b$ ), a prova relativa à expedição postal dentro do prazo determinado e, em caso de perda do documento ou da carta, também o documento ou a carta a serem remetidos em substituição deverão ser apresentados no prazo de um mês a contar da data em que a parte interessada constatou - ou teria constatado se o tentasse devidamente - o atraso ou a perda, porém nunca mais de seis meses depois da expiração do prazo aplicável no caso determinado.

\subsection{Interrupção do serviço postal}

a) Com ressalvadas das disposições da regra 22.3 qualquer parte interessada poderá tentar provar que, em qualquer um dos 10 dias que precederam a data de expiração do prazo, o serviço postal esteve interrompido por motivo de guerra, revolução, desordem civil, greve, calamidade natural ou outras razões semelhantes, na localidade em que a parte interessada tenha seu domicílio ou sua sede, ou esteja residindo no momento.

b) Se ficar provado a contento da Repartição nacional ou da organização intergovernamental destinatária que tais circunstâncias existiram, o atraso na chegada será desculpado, desde que a parte interessada prove a contento da dita Repartição ou da dita organização que efetuou a expedição postal dentro dos 5 dias seguintes à volta ao funcionamento do serviço postal. As disposições da regra 82.1.c) aplicar-se-ão mutatis mutandis.

\section{Regra 83}

Direito de exercer junto a Administrações internacionais

83.1 Prova de direito

O Escritório Internacional, a Administração competente encarregada da pesquisa internacional e a Administração competente encarregada do exame preliminar internacional poderão exigir a produção da prova do direito de exercer a que se refere o artigo 49.

\subsection{Informação}

a) A Repartição nacional ou a organização intergovernamental, em função das quais for alegado que a pessoa interessada tem o direito de exercer, deverá, a pedido, informar ao Escritório 
Internacional, à Administração competente encarregada da pesquisa internacional ou à Administração Competente encarregada do exame preliminar internacional, se essa pessoa tem o direito de exercer junto a elas.

b) Uma tal informação obrigará Escritório Internacional, a Administração encarregada da pesquisa internacional ou a Administração encarregada do exame preliminar internacional, conforme o caso.

\section{PARTE E}

Regras Relativas ao Capítulo V do Tratado

Regra 84

Despesas das delegações

84.1 Despesas incorridas pelos governos

As despesas de cada delegação que participa de qualquer organismo criado pelo Estado ou em virtude do mesmo serão incorridas pelo governo que a houver designado.

Regra 85

Falta de quorum na Assembléia

\subsection{Voto por correspondência}

No caso previsto no artigo 53.5)b), o Escritório Internacional comunicará as decisões da Assembléia (exclusive as que dizem respeito ao procedimento interno da Assembléia) aos Estados contratantes que nela não estiverem representados, convidando-os a expressar por escrito, no prazo de três meses a contar da data da dita comunicação, seu voto ou sua abstenção. Se, ao expirar esse prazo, o número dos Estados contratantes que assim expressaram seu voto ou sua abstenção alcançar o número de Estados contratantes que faltou para que fosse atingido o quorum na ocasião da sessão, tais decisões entrarão em vigor, desde que ao mesmo tempo permaneça assegurada a maioria necessária.

Regra 86

\section{Gazeta}

\subsection{Conteúdo}

a) A Gazeta mencionada no artigo 55.4) conterá:

I) em relação a cada pedido internacional publicado, os dados especificados nas Instruções Administrativas retirados da página de cobertura da brochura publicada de acordo com a regra 48, os desenhos (se os houver) que figurem na dita página e o resumo;

II) a tabela de todas as taxas pagáveis às Repartições receptoras, ao Escritório Internacional, às Administrações encarregadas da pesquisa internacional e às Administrações encarregadas do exame preliminar internacional;

III) as notificações cuja publicação seja exigida de acordo com o Tratado ou o presente Regulamento de execução;

IV) todas as informações, se as mesmas foram, e na medida em que foram fornecidas ao Escritório Internacional pelas Repartições designadas ou eleitas, relativas à questão de saber se os atos mencionados nos artigos 22 ou 39 foram realizados em relação aos pedidos internacionais que designaram ou elegeram a Repartição interessada; 
V) qualquer outras informações úteis especificadas nas Instruções Administrativas, contando que o acesso a tais informações não seja proibido em virtude do Tratado ou do presente Regulamento de execução.

\subsection{Línguas}

a) A Gazeta será publicada em edição francesa e inglesa. Edições em qualquer outra língua serão igualmente publicadas, desde que o custo de publicação seja assegurado pelas vendas ou por subvenções.

b) A Assembléia poderá ordenar a publicação da Gazeta em outras línguas além das mencionadas na alínea $a$ )

\subsection{Periodicidade}

A Gazeta será publicada uma vez por semana.

86.4 Venda

Os preços de assinatura e das vendas avulsas as Gazeta serão fixados nas Instruções Administrativas.

86.5 Título

O título da Gazeta será "Gazette des demandes internationales de brevest" e "Gazette of Internacional Patent Applications", respectivamente.

\subsection{Outros pormenores}

Outros pormenores relativos à Gazeta poderão ser especificados nas Instruções Administravas.

Regra 87

Cópias de publicações

87.1 Administrações encarregadas da pesquisa internacional e do exame preliminar internacional

Qualquer Administração encarregada da pesquisa internacional ou do exame preliminar internacional terá o direito de receber gratuitamente duas cópias de cada pedido internacional publicado, da Gazeta e de qualquer outra publicação de interesse geral publicada pelo Escritório Internacional a respeito do Tratado ou do presente Regulamento de execução.

87.2 Repartições nacionais

a) Qualquer Repartição nacional terá o direito de receber gratuitamente uma cópia de cada pedido internacional, da Gazeta e de qualquer outra publicação de interesse geral, publicada pelo Escritório Internacional a respeito do Trabalho ou do presente Regulamento de execução.

b) As publicações mencionadas na alínea $a$ ) serão remetidas a pedido especial apresentado, em relação a cada ano, em 30 de Novembro do ano precedente - Caso uma publicação seja editada em várias línguas o pedido deverá especificar em que língua deseja receber a publicação.

\section{Regra 88}

Modificação do Regulamento de execução

88.1 Exigência de unanimidade

A emenda da disposições seguintes do presente Regulamento de execução exigirá que nenhum Estado com direito de voto na Assembléia vote contra a emenda proposta:

I) regra 14.1 (taxa de transmissão);

II) regra 22.2 (transmissão da via original; processo alternativo); 
III) regra 22.3 (prazo previsto no artigo 12.3));

IV) regra 33 (estado da técnica pertinente para fins de pesquisa internacional);

V) regra 64 (estado da técnica para fins de exame preliminar internacional);

VI) regra 81 (modificação dos prazos fixados no Tratado);

VII) a presente alínea (isto é, regra 88.1).

88.2 Exigência de unanimidade durante um período de transição

Durante os primeiros 5 anos depois da entrada em vigor do Tratado, a emenda das seguintes disposições deste Regulamento de execução exigirá que nenhum Estado com direito de voto na Assembléia vote contra a emenda proposta:

I) regra 5 (a descrição);

II) regra 6 (as reivindicações);

III) a presente alínea (isto é regra 88.2)

88.3 Exigência de ausência de oposição de certos Estados

A emenda das disposições seguintes deste Regulamento de execução exigirá que nenhum Estado a que se refere o artigo 58.3ㄱ)II) e com direito de voto na Assembléia vote contra a emenda proposta:

I) regra 34 (documentação mínima);

II) regra 39 (matéria a que se refere o artigo 17.2)a)I));

III) regra 67 (matéria a que se refere o artigo 34.4)a)I));

IV) a presente alínea (isto é, regra 88.3).

\subsection{Processo}

Qualquer proposta de emenda de uma das disposições mencionadas na regras 88.1, 88.2 ou 88.3, caso caiba à Assembléia pronunciar-se sobre o assunto, deverá ser comunicada a todos os Estados contratantes dois meses pelo menos antes da abertura da sessão da Assembléia que deverá tomar uma decisão a respeito da dita proposta.

\section{Regra 89}

Instruções Administrativas

\subsection{Extensão}

a) As Instruções Administrativas conterão disposições concernentes a:

I) questões a respeito das quais o presente Regulamento citar expressamente as ditas Instruções;

II) qualquer pormenor relativo à aplicação do presente Regulamento de execução.

b) As Instruções Administrativas não deverão colidir com o Tratado, com o presente Regulamento de execução ou com qualquer acordo concluído pelo Escritório Internacional com uma Administração encarregada da pesquisa internacional ou uma Administração encarregada do exame preliminar internacional.

89.2 Fonte

a) As Instruções Administrativas serão redigidas e promulgadas pelo Diretor-Geral, depois de consultadas as Repartições receptoras, as Administrações encarregadas da pesquisa internacional e as Administrações encarregadas do exame preliminar internacional. 
b) Elas poderão ser modificadas pelo Diretor-Geral depois de consultadas as Repartições ou Administrações que tiverem interesse direto na modificação proposta.

c) A Assembléia poderá convidar o Diretor-Geral a modificar as Instruções Administrativas, e o Diretor-Geral agirá em conseqüência.

89.3 Publicação e entrada em vigor

a) As Instruções Administrativas e qualquer modificação que lhes seja introduzida serão publicadas na Gazeta.

b) Cada publicação especificará a data em que as disposições publicadas entrarão em vigor. As datas poderão ser diferentes em relação a disposições diferentes, desde que nenhuma disposição seja posta em vigor antes de sua publicação na Gazeta.

\section{PARTE F}

Regras Relativas a Vários Capítulos do Tratado

Regra 90

Representação

90.1 Definições

Para os fins das regras 90.2 e 90.3:

I) deve-se entender por "mandatário" qualquer uma das pessoas mencionadas no artigo 49;

II) dever-se entender por "representante comum" o depositante a que se refere a regra 4.8.

\subsection{Efeitos}

a) Qualquer ato efetuado por um mandatário, ou relação a um mandatário, terá os efeitos de um ato efetuado pelo, ou em relação ao depositante ou depositantes que nomearam o mandatário.

b) Qualquer ato efetuado por, ou em relação a um representante comum ou seu mandatário terá os efeitos de um ato efetuado por, ou em relação a todos os depositantes.

c) Se vários mandatários forem nomeados pelo mesmo depositante ou depositantes, qualquer ato efetuado por, ou em relação a qualquer um desses diversos mandatários terá os efeitos de um ato efetuado pelo, ou em relação ao dito depositante ou aos ditos depositantes.

d) Os efeitos descritos na alíneas $a$ ), $b$ ) e $c$ ) se estenderão ao processo do pedido internacional pela Repartição receptora, o Escritório Internacional, a Administração encarregada da pesquisa internacional e a Administração encarregada do exame preliminar internacional.

\subsection{Nomeação}

a) A nomeação de um mandatário ou de um representante comum no sentido que lhe empreste a regra 4.8.a), caso o dito mandatário ou representante comum não seja nomeado no requerimento assinado por todos os depositantes, deverá ser feita por uma procuração assinada, separada (isto é, um documento nomeado um mandatário ou um representante comum).

b) A procuração poderá ser depositada na Repartição receptora ou no Escritório Internacional. Aquele em que a procuração for depositada notificará prontamente o outro bem como a Administração interessada encarregada da pesquisa internacional e a Administração interessada encarregada do exame preliminar internacional.

c) Se a procuração separada não estiver assinada como previsto na alínea $a$ ), ou se essa procuração separada estiver faltando, ou ainda se a indicação do nome ou do endereço da pessoa nomeada não estiver conforme a regra 4.4, a procuração será considerada como inexistente até correção da falha. 


\subsection{Revogação}

a) Qualquer nomeação poderá ser revogada pelas pessoas, ou seus procuradores, que fizeram a nomeação.

b) A regra 90.3 aplicar-se-á, mutatis mutandis, ao documento que contém a revogação.

Regra 91

Erros evidentes de transcrição

91.1 Retificação

a) Com ressalva das alíneas $b$ ) a $g$ ), os erros evidentes de transcrição, no pedido internacional ou em outros documentos apresentados pelo depositante, poderão ser retificados.

b) Os erros devidos ao fato de que, no pedido internacional ou nos outros documentos, estivesse escrito algo diferente do que, com toda evidência, fora desejado, serão considerados como erros evidentes de transcrição. A retificação ela própria deverá ser evidente no sentido de que qualquer um deverá perceber de pronto que nada senão o texto proposto como retificação poderia ter sido desejado.

c) Omissões de elementos inteiros ou de folhas inteiras do pedido internacional, mesmo resultantes claramente de uma desatenção, ao ser feita uma cópia ou ao serem juntadas as folhas, por exemplo, não serão consideradas retificáveis.

d) Qualquer retificação poderá ser feita a pedido do depositante. A Administração que houver descoberto o que pareça constituir um erro evidente de transcrição poderá convidar o depositante a apresentar um pedido de retificação, tal como disposto nas alíneas $e$ ) a $g$ ).

e) Qualquer retificação exigirá a autorização expressa:

I) da Repartição receptora, se o erro se encontrar no requerimento;

II) da Administração encarregada da pesquisa internacional, se o erro figurar em outra parte do pedido internacional ou em outro documento apresentado a essa Administração;

III) da Administração encarregada do exame preliminar internacional, se o erro figurar em outra parte do pedido internacional que não o requerimento ou em outro qualquer documento apresentado a essa Administração; e

IV) do Escritório Internacional se o erro figurar em um outro documento qualquer além do pedido internacional ou das modificações ou correções desse pedido, apresentados ao Escritório Internacional.

f) A data da autorização será inscrita no processo do pedido internacional.

g) A autorização para retificar a que se refere a alínea $e$ ) poderá ser concedida até que ocorra uma das seguintes circunstâncias:

I) no caso de autorização concedida pela Repartição receptora e o Escritório Internacional, a comunicação do pedido internacional a que se refere o artigo 20;

II) no caso de autorização concedida pela Administração encarregada da pesquisa internacional, a aprovação do relatório de pesquisa internacional ou da declaração tal como disposto no artigo 17.2)a);

III) no caso de autorização concedida pela Administração encarregada do exame preliminar de pesquisa internacional, a aprovação do relatório de exame preliminar internacional.

h) Qualquer retificação autorizada por autoridades outras que não o Escritório Internacional deverá ser prontamente comunicada por essa autoridade ao dito Escritório. 


\section{Regra 92}

\section{Correspondência}

\subsection{Cartas de acompanhamento e assinaturas}

a) Qualquer documento, além do pedido internacional ele próprio, submetido pelo depositante no curso do processo internacional previsto no Tratado e no presente Regulamento de execução - se não constituir ele próprio uma carta - deverá ser acompanhado por uma carta que identifique o pedido internacional a que ele se refere. A carta deverá ser assinada pelo depositante.

b) Se as condições a que se refere a alínea $a$ ) não forem preenchidas, o documento será considerado como não havendo sido submetido.

\subsection{Línguas}

a) Como ressalva das alíneas $b$ ) e $c$ ), qualquer carta ou documento endereçado ou submetido pelo depositante à Administração encarregada do exame preliminar internacional deverá ser redigido na mesma língua que o pedido internacional ao qual diga respeito.

b) Qualquer carta do depositante à Administração encarregada da pesquisa internacional ou à Administração encarregada do exame preliminar internacional poderá ser redigida em outra língua além daquela do pedido internacional se a dita Administração autorizar o uso dessa língua.

c) Quando uma tradução for exigida de acordo com a regra 55.2, a Administração encarregada do exame preliminar internacional poderá exigir que toda a carta que lhe for endereçada pelo depositante seja redigida na língua dessa tradução.

d) Qualquer carta do depositante ao Escritório Internacional deverá ser redigida em francês ou inglês.

e) Qualquer carta ou notificação do Escritório Internacional ao depositante ou a qualquer Repartição nacional deverá ser redigida em francês ou em inglês.

92.3 Expedições postais pelas Repartições nacionais e as organizações intergovernamentais

Qualquer documento ou carta que emane de, ou seja transmitido por uma Repartição nacional ou uma organização intergovernamental e que constitua uma ocorrência a partir da qual tenha início um prazo, de acordo com o Tratado ou o presente Regulamento de execução, deverá ser expedido por correio aéreo registrado, ficando entendido que o correio por via terrestre ou marítima poderá ser utilizado em lugar do correio aéreo quando o primeiro chegue normalmente ao destino no prazo de dois dias depois da expedição ou quando não haja correio aéreo.

\section{Regra 93}

\section{Processos e registros}

\subsection{Repartição receptora}

Toda Repartição receptora conservará os processos e registros relativos a cada pedido internacional ou alegando pedido internacional, inclusive a cópia para a Repartição receptora, durante 10 anos pelo menos a contar da data do depósito internacional ou, quando esta não houver sido concedida, a contar da data do recebimento.

\subsection{Escritório Internacional}

a) O Escritório Internacional conservará o processo, incluindo a via original, de todo pedido internacional durante 30 anos pelo menos a contar da data de recebimento da via original.

b) Os processos e registros básicos do Escritório Internacional serão conservados indefinidamente.

93.3 Administrações encarregadas da pesquisa internacional e Administrações encarregadas do exame preliminar internacional 
Cada Administração encarregada da pesquisa internacional e cada Administração encarregada do exame preliminar internacional conservará durante pelo menos 10 anos a contar da data do depósito internacional, o processo de cada pedido internacional.

\subsection{Reproduções}

Para os fins da presente regra, os processos, cópias e registros compreenderão igualmente as reproduções fotográficas dos processos, cópias e registros, seja qual for a forma dessas reproduções (microfilmes ou outras).

\section{Regra 94}

Remessa de cópias pelo Escritório Internacional e pela Administração encarregada do exame preliminar internacional

\subsection{Obrigação de remeter}

A pedido do depositante ou de qualquer pessoa autorizada pelo depositante, o Escritório Internacional e a Administração encarregada do exame preliminar internacional remeterão, contra reembolso do custo ao serviço, cópias de todo documento incluído no processo do pedido internacional ou do alegado pedido internacional do depositante.

\section{Regra 95}

Disponibilidade de traduções

95.1 Fornecimento de cópias de traduções

a) A pedido do Escritório Internacional, qualquer Repartição designada ou eleita fornecerá uma cópia de tradução do pedido internacional submetida pelo depositante à dita Repartição.

b) O Escritório Internacional poderá, a pedido e contra reembolso do custo, fornecer a qualquer pessoa cópias das traduções que receber em virtude da alínea $a$ ).

Este texto não substitui o original publicado no Diário Oficial da União - Seção 1 de 01/06/1978

\section{Publicação:}

- Diário Oficial da União - Seção 1 - 1/6/1978, Página 8120 (Publicação Original)

- $\quad$ Coleção de Leis do Brasil - 1978, Página 367 Vol. 4 (Publicação Original) 


\section{DECRETO Nº 1.263, DE 10 DE OUTUBRO DE 1994}

Ratifica a declaração de adesão aos arts. $1^{\circ}$ a 12 ao art.28, alínea 1 , do texto da revisão de Estocolmo da Convenção de París para Proteção da Propriedade Industrial.

O PRESIDENTE DA REPÚBLICA, no uso da atribuição que lhe confere o art. 84, inciso VIII, da Constituição,

DECRETA:

Art. $\mathbf{1}^{\mathbf{0}}$. Fica ratificada a declaração constante do Decreto ${ }^{0}$ 635, de 21 de agosto de 1992, da extensão da adesão da República Federativa do Brasil aos arts. $1^{\circ}$ a 12 e ao art. 28, alínea 1, do texto da Revisão de Estocolmo da Convenção de Paris para a Proteção da Propriedade Industrial, constante do anexo a este Decreto.

Art. $2^{\circ}$. Este Decreto entra em vigor na data de sua publicação.

Brasília, 10 de outubro de 1994; $173^{\circ}$ da Independência e $106^{\circ}$ da República.

ITAMAR FRANCO

Celso Luiz Nunes Amorim

\section{CONVENÇÃO DE PARIS PARA A PROTEÇÃO DA PROPRIEDADE INDUSTRIAL, DE 20 DE MARÇO DE 1883}

(Revista em Bruxelas a 14 de dezembro de 1900 em Washington a 2 de junho de 1911 na Haia a 6 de novembro de 1925 em Londres a 2 de junho de 1934 em Lisboa a 31 de outubro de 1958 e em Estocolmo a 14 de julho de 1967)

\section{Artigo 1}

1) Os países a que se aplica a presente Convenção constituem-se em União para a proteção da propriedade industrial.

2) A proteção da propriedade industrial tem por objeto as patentes de invenção, os modelos de utilidade, os desenhos ou modelos industriais, as marcas de fábrica ou de comércio, as marcas de serviço, o nome comercial e as indicações de proveniência ou denominações de origem, bem como a repressão da concorrência desleal.

3) A propriedade industrial entende-se na mais ampla acepção e aplica-se não só a indústria e ao comércio propriamente ditos, mas também às indústrias agrícolas e extrativas e a todos os produtos manufaturados ou naturais, por exemplo: vinhos, cereais, tabaco em folha, frutas, animais, minérios, águas minerais, cervejas, flores, farinhas.

4) Entre as patentes de invenção compreendem-se as diversas espécies de patentes industriais admitidas nas legislações dos países da União, tais como patentes de importação, patentes de aperfeiçoamento, patentes e certificados de adição, etc.

\section{Artigo 2}

1) Os nacionais de cada um dos países da União gozarão em todos os outros países da União, no que se refere à proteção da propriedade industrial, das vantagens que as leis respectivas concedem atualmente ou venham a conceder no futuro aos nacionais, sem prejuízo dos direitos especialmente previstos na presente Convenção. Em conseqüência, terão a mesma proteção que estes e os mesmos recursos legais contra qualquer atentado dos seus direitos, desde que observem as condições e formalidades impostas aos nacionais.

2) Nenhuma condição de domicílio ou de estabelecimento no país em que a proteção é requerida pode, porém, ser exigida dos nacionais de países da União para o gozo de qualquer dos direitos de propriedade industrial. 
3) Ressalvam-se expressamente as disposições da legislação de cada um dos países da União relativas ao processo judicial e administrativo e à competência, bem como à escolha de domicílio ou à designação de mandatário, eventualmente exigidas pelas leis de propriedade industrial.

\section{Artigo 3}

São equiparados aos nacionais dos países da União os nacionais dos países não participantes da União domiciliados ou que possuam estabelecimentos industriais ou comerciais efetivos e reais no território de um dos países da União.

\section{Artigo 4}

A. 1) Aquele que tiver devidamente apresentado pedido de patente de invenção, de depósito de modelo de utilidade, de desenho ou modelo industrial, de registro de marca de fábrica ou de comércio num dos países da União, ou o seu sucessor, gozará, para apresentar o pedido nos outros países, do direito de prioridade durante os prazos adiante fixados.

2) Reconhece-se como dando origem ao direito de prioridade qualquer pedido com o valor de pedido nacional regular, em virtude da legislação nacional de cada país da União ou de tratados bilaterais ou multilaterais celebrados entre países da União.

3) Deve entender-se por pedido nacional regular qualquer pedido efetuado em condições de estabelecer a data em que o mesmo foi apresentado no país em causa, independentemente do resultado ulterior do pedido.

B. Em conseqüência, o pedido apresentado ulteriormente num dos outros países da União, antes de expirados estes prazos não poderá ser invalidado por fatos verificados nesse intervalo, como por exemplo outro pedido, publicação da invenção ou sua exploração, oferecimento à venda de exemplares do desenho ou do modelo ou uso da marca, e esses fatos não poderão fundamentar qualquer direito de terceiros ou posse pessoal. Os direitos adquiridos por terceiros antes do dia do primeiro pedido que serve de base ao direito de prioridade são ressalvados nos termos da legislação interna de cada país da União.

C. 1) Os prazos de prioridade acima mencionados serão de doze meses para invenções e modelos de utilidade e de seis meses para os desenhos ou modelos industriais e para as marcas de fábrica ou de comércio.

2) Estes prazos correm a partir da data da apresentação do primeiro pedido; o dia da apresentação não é contado.

3) Se o último dia do prazo for feriado legal ou dia em que a Repartição se encontre aberta para receber a apresentação dos pedidos no país em que a proteção é requerida, o prazo será prorrogado até o primeiro dia útil seguinte.

4) Deve ser considerado como primeiro pedido, cuja data de apresentação marcará o início do prazo de prioridade, pedido ulterior que tenha o mesmo objeto de um primeiro pedido anterior, nos termos do parágrafo 2), apresentado no mesmo país da União, desde que na data do pedido posterior, o pedido anterior tenha sido retirado, abandonado ou recusado, sem ter sido submetido a inspeção pública e sem deixar subsistir direitos e que não tenham ainda servido de base para reivindicação do direito de prioridade. O pedido anterior então não poderá mais servir de base para reivindicação do direito de prioridade.

D. 1) Quem quiser prevalecer-se da prioridade de um pedido anterior deverá formular declaração em que indique a data e o país desse pedido. Cada país fixará o momento até ao qual esta declaração deverá ser efetuada.

2) Estas indicações serão mencionadas nas publicações emanadas da autoridade competente, particularmente nas patentes e suas descrições.

3) Os países da União poderão exigir daquele que fizer uma declaração de prioridade a apresentação de uma cópia do pedido (descrição, desenhos, etc.) entregue anteriormente. A cópia autenticada pela autoridade que houver recebido esse pedido estará isenta de qualquer legislação e poderá, em qualquer caso, ser apresentada, sem ônus, em qualquer momento no prazo de três meses a contar da data da apresentação do pedido ulterior. Poderá exigir-se que seja acompanhada de certificado da data da apresentação, expedido pela mesma autoridade e de tradução. 
4) Para a declaração de prioridade nenhuma outra formalidade poderá ser exigida no momento da apresentação do pedido. Cada país da União determinará quais as conseqüências da omissão das formalidades previstas no presente artigo, as quais não poderão exceder a perda do direito de prioridade.

5) Ulteriormente poderão ser exigidas outras justificativas.

Aquele que reivindicar a prioridade de um pedido anterior terá de indicar o número desse pedido; essa indicação será publicada nas condições previstas no parágrafo 2) acima.

E. 1) Quando um desenho ou modelo industrial tiver sido depositado num país, em virtude de um direito de prioridade baseado no pedido de depósito de um modelo de utilidade, o prazo de prioridade será somente o fixado para os desenhos ou modelos industriais.

2) Além disso, é permitido depositar num país um modelo de utilidade, em virtude de um direito de prioridade baseado num pedido de patente e vice-versa.

F. Nenhum país da União poderá recusar prioridade ou pedido de patente em virtude de o requerente reivindicar prioridades múltiplas, mesmo provenientes de diferentes países, ou em virtude de um pedido reivindicando uma ou várias prioridades conter um ou mais elementos que não estavam compreendidos no ou nos pedidos cuja prioridade se reivindica, com a condição de, nos dois casos, haver unidade de invenção, no sentido da lei do país.

No que se refere aos elementos não compreendidos no ou nos pedidos cuja prioridade se reivindica, a apresentação do pedido ulterior dá lugar a um direito de prioridade, nas condições usuais.

G. 1) Se o exame revelar que um pedido de patente é complexo, poderá o requerente dividir o pedido num certo número de pedidos divisionários, cada um dos quais conservará a data do pedido inicial e, se for o caso, o benefício do direito de prioridade.

2) O requerente poderá também, por sua própria iniciativa, dividir o pedido de patente, conservando como data de cada pedido divisionário a data do pedido inicial e, se for o caso, o benefício do direito de prioridade. Cada país da União terá a faculdade de fixar as condições nas quais esta divisão será autorizada.

H. A prioridade não pode ser recusada com o fundamento de que certos elementos da invenção para os quais se reivindica a prioridade não figuram entre as reivindicações formuladas no pedido apresentado no país de origem, contando que o conjunto dos documentos do pedido revele de maneira precisa aqueles elementos.

I. 1) Os pedidos de certificados de autor de invenção depositados num país em que os requerentes têm o direito de pedir, à sua escolha, quer uma patente, quer um certificado de autor de invenção, darão origem ao direito de prioridade instituído pelo presente artigo, nas mesmas condições e com os mesmos efeitos que os pedidos de patentes de invenção.

2) Num país em que os requerentes têm o direito de requerer, à sua escolha, quer uma patente, quer um certificado de autor de invenção, o requerente de um certificado de autor de invenção se beneficiará, segundo as disposições do presente artigo aplicáveis aos pedidos de patentes, do direito de prioridade baseado no depósito de um pedido de patente de invenção, de modelo de utilidade ou de certificado de autor de invenção.

\section{Artigo 4 bis}

1) As patentes requeridas nos diferentes países da União por nacionais de países da União serão independentes das patentes obtidas para a mesma invenção nos outros países, membros ou não da União.

2) Esta disposição deve entender-se de modo absoluto, particularmente no sentido de que as patentes pedidas durante o prazo de prioridade são independentes, tanto do ponto de vista das causas de nulidade e de caducidade como do ponto de vista da duração normal.

3) Aplica-se a todas as patentes existentes à data da sua entrada em vigor.

4) O mesmo sucederá, no caso de acessão de novos países, às patentes existentes em ambas as partes, à data de acessão. 
5) As patentes obtidas com o benefício da prioridade gozarão, nos diferentes países da União, de duração igual àquela de que gozariam se fossem pedidas ou concedidas sem o benefício da prioridade.

Artigo 4 ter

O inventor tem o direito de ser mencionado como tal na patente.

\section{Artigo 4 quater}

Não poderá ser recusada a concessão de uma patente e não poderá ser uma patente invalidada em virtude de estar a venda do produto patenteado ou obtido por um processo patenteado sujeito a restrições ou limitações resultantes da legislação nacional.

\section{Artigo 5}

A. 1) A introdução, pelo titular da patente, no país em que esta foi concedida, de objetos fabricados em qualquer dos países da União não acarreta a caducidade da patente.

2) Cada país da União terá a faculdade de adotar medidas legislativas prevendo a concessão de licenças obrigatórias para prevenir os abusos que poderiam resultar do exercício do direito exclusivo conferido pela patente, como, por exemplo, a falta de exploração.

3) A caducidade da patente só poderá ser prevista para os casos em que a concessão de licenças obrigatórias não tenha sido suficiente para prevenir tais abusos. Não poderá ser interposta ação de declaração de caducidade ou de anulação de uma patente antes de expirar o prazo de dois anos, a contar da concessão da primeira licença obrigatória.

4) Não poderá ser pedida licença obrigatória, com o fundamento de falta ou insuficiência de exploração, antes de expirar o prazo de quatro anos a contar da apresentação do pedido de patente, ou de três anos a contar da concessão da patente, devendo aplicar-se o prazo mais longo; a licença será recusada se o titular da patente justificar a sua inação por razões legítimas. Tal licença obrigatória será não exclusiva só será transferível, mesmo sob a forma de concessão de sublicença, com a parte da empresa ou do estabelecimento comercial que a explore.

5) As disposições precedentes serão aplicáveis, com as modificações necessárias, aos modelos de utilidade.

B. A proteção dos desenhos e modelos industriais não caducará por falta de exploração nem por introdução de objetos semelhantes aos que estão protegidos.

C. 1) Se num país o uso da marca registrada for obrigatório, o registro só poderá ser anulado depois de decorrido um prazo razoável e se o interessado não justificar a sua inação.

2) O uso, pelo proprietário, de uma marca de fábrica ou de comércio de forma diferente, quanto a elementos que não alteram o caráter distintivo da marca, da forma por que esta foi registrada num dos países da União não implicará a anulação do registro nem diminuirá a proteção que lhe foi concedida

3) O uso simultâneo da mesma marca em produtos idênticos ou semelhantes por estabelecimentos industriais ou comerciais considerados co-proprietários da marca, segundo os dispositivos da lei nacional do país onde a proteção é requerida, não impedirá o registro nem diminuirá, de maneira alguma, a proteção concedida à referida marca em qualquer dos países da União, contando que o referido uso não tenha como efeito induzir o público em erro nem seja contrário ao interesse público.

D. Para reconhecimento do direito não será exigido no produto qualquer sinal ou menção da patente, do modelo de utilidade, ou do registro da marca de fábrica ou de comércio, ou de depósito do desenho ou modelo industrial.

\section{Artigo 5 bis}

1) Uma prorrogação de prazo, de no mínimo seis meses, será concedida para o pagamento das taxas previstas para a manutenção dos direitos de propriedade industrial, mediante o pagamento de uma sobretaxa, se a legislação nacional assim dispuser. 
2) Os países da União têm a faculdade de prever a revalidação das patentes de invenção caducadas em virtude de não pagamento de taxas.

\section{Artigo 5 ter}

Em cada um dos países da União não serão considerados lesivos dos direitos do titular da patente:

1) O emprego, a bordo dos navios dos outros países da União, dos meios que constituem o objeto da sua patente no corpo do navio, nas máquinas, mastreação, aprestos e outros acessórios, quando esses navios penetrarem temporária ou acidentalmente em águas do país, sob reserva de que tais meios sejam empregados exclusivamente para as necessidades do navio;

2) $\mathrm{O}$ emprego dos meios que constituem o objeto da patente na construção ou no funcionamento de aeronaves ou veículos terrestres dos outros países da União, ou dos acessórios dessas aeronaves ou veículos terrestres quando estes penetrarem temporária ou acidentalmente no país.

\section{Artigo 5 quater}

Quando um produto for introduzido num país da União no qual exista uma patente protegendo um processo de fabricação desse produto, o titular da patente terá, com referência ao produto introduzido, todos os direitos que a legislação do país de importação lhe conceder, em virtude da patente desse processo, com referência aos produtos fabricados no próprio país.

\section{Artigo 5 quinquies}

Os desenhos e modelos industriais serão protegidos em todos os países da União.

\section{Artigo 6}

1) As condições de depósito e de registro das marcas de fábrica ou de comércio serão determinadas, em cada país da União, pela respectiva legislação nacional.

2) Não poderá, todavia, ser recusada ou invalidada uma marca requerida em qualquer dos países da União por um nacional de um país desta, com o fundamento de não ter sido depositada, registrada ou renovada no país de origem.

3) Uma marca regularmente registrada num país da União será considerada como independente das marcas registradas nos outros países da União inclusive o país de origem.

\section{Artigo 6 bis}

1) Os países da União comprometem-se a recusar ou invalidar o registro, quer administrativamente, se a lei do país o permitir, quer a pedido do interessado e a proibir o uso de marca de fábrica ou de comércio que constitua reprodução, imitação ou tradução, suscetíveis de estabelecer confusão, de uma marca que a autoridade competente do país do registro ou do uso considere que nele é notoriamente conhecida como sendo já marca de uma pessoa amparada pela presente Convenção, e utilizada para produtos idênticos ou similares. O mesmo sucederá quando a parte essencial da marca constitui reprodução de marca notoriamente conhecida ou imitação suscetível de estabelecer confusão com esta.

2) Deverá ser concedido um prazo mínimo de cinco anos a contar da data do registro, para requerer cancelamento de tal marca. Os países da União têm a faculdade de prever um prazo dentro do qual deverá ser requerida a proibição de uso.

3) Não será fixado prazo para requerer o cancelamento ou a proibição de uso de marcas registradas ou utilizadas de má fé.

\section{Artigo 6 ter}

1) a) Os países da União acordam em recusar ou invalidar o registro e em impedir, através de medidas adequadas, o uso, sem autorização das autoridades competentes, quer como marcas de fábrica ou de comércio, quer como elementos dessas marcas, de armas, bandeiras e outros emblemas de Estado dos países da União, sinais e timbres oficiais de fiscalização e de garantia por eles adotados, bem como qualquer imitação do ponto de vista heráldico. 
b) As disposições do subparágrafo a) acima aplicam-se igualmente às armas, bandeiras e outros emblemas, siglas ou denominações de organismos internacionais intergovernamentais de que um ou vários países da União sejam membros, com exceção de armas, bandeiras e outros emblemas, siglas ou denominações que já tenham sido objeto de acordos internacionais vigentes, destinados a assegurar a sua proteção.

c) Nenhum país da União terá de aplicar as disposições do subparágrafo b) acima em detrimento dos titulares de direitos adquiridos de boa fé, antes da entrada em vigor nesse país da presente Convenção. Os países da União não são obrigados a aplicar as referidas disposições quando o uso ou o registro mencionado no subparágrafo a) não for de natureza a sugerir, no espírito do público, uma ligação entre a organização em apreço e as armas, bandeiras, emblemas, siglas ou denominações, ou se este uso ou registro não for claramente de natureza a induzir o público em erro sobre a existência de ligação entre o utilizador e a organização.

2) A proibição dos sinais e timbres oficiais de fiscalização e de garantia só se aplica aos casos em que as marcas que os incluem se destinam a ser usadas em mercadorias do mesmo gênero ou de gênero similar.

3) a) Para a aplicação destas disposições, os países da União acordam em dar a conhecer reciprocamente, por intermédio da Repartição Internacional, a lista dos emblemas de Estado, sinais e timbres oficiais de fiscalização e de garantia que desejam ou desejarão colocar, de uma maneira absoluta ou dentro de certos limites, sob a proteção do presente artigo, bem como todas as modificações ulteriormente introduzidas nessa lista. Cada país da União porá à disposição do público, oportunamente, as listas notificadas. Entretanto, esta notificação não é obrigatória no que se refere às bandeiras dos Estados.

b) As disposições do subparágrafo b) do parágrafo 1) do presente artigo são unicamente aplicáveis às armas, bandeiras e outros emblemas, siglas ou denominações das organizações internacionais intergovernamentais que estas comunicaram aos países da União por intermédio da Repartição Internacional.

4) Qualquer país da União poderá, no prazo de doze meses a contar do recebimento da notificação, transmitir, por intermédio da Repartição Internacional, as suas eventuais objeções ao país ou à organização internacional intergovernamental interessados.

5) Com referência às bandeiras de Estado, apenas se aplicarão as medidas previstas no parágrafo 1) às marcas registradas depois de 6 de novembro de 1925.

6) Com referência aos emblemas de Estado que não sejam bandeiras, aos sinais e timbres oficiais dos países da União e às armas, bandeiras e outros emblemas, siglas ou denominações das organizações internacionais intergovernamentais, estas disposições só serão aplicáveis às marcas registradas mais de dois meses depois do recebimento da notificação prevista no parágrafo 3) acima.

7) Em caso de má fé, os países terão a faculdade de cancelar o registro das marcas que contenham emblemas de Estado, sinais e timbres, mesmo quando tenham sido registradas antes de 6 de novembro de 1925.

8) Os nacionais de cada país que forem autorizados a usar emblemas de Estado, sinais e timbres do seu país poderão utilizá-los, ainda que sejam semelhantes aos de outro país

9) Os países da União obrigam-se a impedir o uso não autorizado, no comércio, das armas de Estado dos outros países da União, quando esse uso possa induzir em erro quanto à origem dos produtos.

10) As disposições precedentes não obstam a que os países exerçam a sua faculdade de recusar ou invalidar, pela aplicação do no 3 da letra B do Artigo 6 quinquies, as marcas que contenham, sem autorização, armas, bandeiras e outros emblemas de Estado ou sinais e timbres oficiais adotados por um país da União, assim com sinais distintivos das organizações internacionais intergovernamentais, mencionados no parágrafo 1. 


\section{Artigo 6 quater}

1) Quando, de acordo com a legislação de um país da União, a cessão de uma marca não seja válida sem a transmissão simultânea da empresa ou estabelecimento comercial a que a marca pertence, bastará, para que essa validade seja admitida, que a parte da empresa ou do estabelecimento comercial situada nesse país seja transmitida ao cessionário com o direito exclusivo de aí fabricar ou vender os produtos assinalados com marca cedida.

2) Esta disposição não impõe aos países da União a obrigação de considerarem válida a transmissão de qualquer marca cujo uso pelo cessionário fosse, de fato, de natureza a induzir o público em erro, particularmente no que se refere à proveniência, à natureza ou às qualidades substanciais dos produtos a que a marca se aplica.

\section{Artigo 6 quinquies}

A. 1) Qualquer marca de fábrica ou de comércio regularmente registrada no país de origem será admitida para registro e protegida na sua forma original nos outros países da União, com as restrições indicadas no presente artigo. Estes países poderão, antes de procederem ao registro definitivo, exigir a apresentação de um certificado de registro no país de origem, passado pela autoridade competente. Não será exigida qualquer legalização para este certificado.

2) Será considerado país de origem o país da União em que o requerente tenha um estabelecimento industrial ou comercial efetivo e real, e, se não tiver esse estabelecimento na União, o país da União onde tenha o seu domicílio, e, se não tiver domicílio na União, o país da sua nacionalidade, no caso de ser nacional de um país da União.

B. Só poderá ser recusado ou invalidado o registro das marcas de fábrica ou de comércio mencionadas no presente artigo, nos casos seguintes:

1. quando forem suscetíveis de prejudicar direitos adquiridos por terceiros no país em que a proteção é requerida;

2. quando forem desprovidas de qualquer caráter distintivo ou então exclusivamente composta por sinais ou indicações que possam servir no comércio para designar a espécie, a qualidade, a quantidade, o destino, o valor, o lugar de origem dos produtos ou a época da produção, ou que se tenham tornado usuais na linguagem corrente ou nos hábitos leais e constantes do comércio do país em que a proteção é requerida;

3. quando forem contrárias à moral ou à ordem pública e, particularmente, de natureza a enganar o público. Fica entendido que uma marca não poderá ser considerada contrária à ordem pública pela simples razão de que não está de acordo com qualquer dispositivo da legislação sobre as marcas salvo no caso em que o próprio dispositivo se relacione com a ordem pública. Fica, todavia, ressalvada a aplicação do Artigo 10 bis.

C. 1) Para determinar se a marca é suscetível de proteção deverão ser levadas em consideração todas as circunstâncias de fato, particularmente a duração do uso da marca.

2) As marcas de fábrica ou de comércio não poderão ser recusadas nos outros países da União pelo único motivo de diferirem das marcas registradas no país de origem apenas por elementos que não alteram o caráter distintivo nem modificam a identidade das marcas na forma sob a qual foram registradas no referido país de origem.

D. Ninguém se poderá beneficiar das disposições do presente artigo se a marca para a qual reivindica proteção não estiver registrada no país de origem.

E. Em nenhum caso, todavia, a renovação do registro de uma marca no país de origem implicará na obrigação de renovar o registro nos outros países da União onde a marca tenha sido registrada.

F. O benefício da prioridade será concedido aos pedidos de registro de marcas efetuados dentro do prazo do Artigo 4, ainda que o registro no país de origem não ocorra senão após a expiração desse prazo.

\section{Artigo 6 sexies}

Os países da União se comprometem a proteger as marcas de serviço. Não são obrigados a prever o registro dessas marcas. 


\section{Artigo 6 septies}

1) Se o agente ou representante do titular de uma marca num dos países da União pedir, sem autorização deste titular, o registro dessa marca em seu próprio nome, num ou em vários desses países, o titular terá o direito de se opor ao registro pedido ou de requerer o cancelamento ou, se a lei do país o permitir, a transferência a seu favor do referido registro, a menos que este agente ou representante justifique o seu procedimento.

2) O titular da marca terá o direito de, com as reservas do subparágrafo 1), se opor ao uso da sua marca pelo seu agente ou representante, se não tiver autorizado esse uso.

3) As legislações nacionais têm a faculdade de prever um prazo razoável dentro do qual o titular de uma marca deverá fazer valer os direitos previstos no presente artigo.

\section{Artigo 7}

A natureza do produto em que a marca de fábrica ou de comércio deve ser aposta não pode, em caso algum, obstar ao registro da marca.

\section{Artigo 7 bis}

1) Os países da União se comprometem a admitir o registro e a proteger as marcas coletivas pertencentes a coletividades cuja existência não seja contrária à lei do país de origem, ainda que essas coletividades não possuam estabelecimento industrial ou comercial.

2) Cada país será juiz das condições particulares em que a marca coletiva será protegida e poderá recusar a proteção se essa marca for contrária ao interesse público.

3) Entretanto, a proteção dessas marcas não poderá ser recusada a qualquer coletividade cuja existência não contraria a lei do país de origem, em virtude de não se achar estabelecida no país onde a proteção é requerida ou de não se ter constituído nos termos da legislação desse país.

\section{Artigo 8}

O nome comercial será protegido em todos os países da União sem obrigações de depósito ou de registro, quer faça ou não parte de uma marca de fábrica ou de comércio.

\section{Artigo 9}

1) O produto ilicitamente assinalado com uma marca da fábrica ou de comércio ou por um nome comercial será apreendido ao ser importado nos países da União onde essa marca ou esse nome comercial têm direito a proteção legal.

2) A apreensão será igualmente efetuada no país onde a aposição ilícita tenha sido feita ou no país onde o produto tenha sido importado.

3) A apreensão será efetuada a requerimento do Ministério Público, de qualquer outra autoridade competente ou de qualquer interessado, pessoa física ou jurídica, de acordo com a lei interna de cada país.

4) As autoridades não serão obrigadas a efetuar a apreensão em caso de trânsito.

5) Se a legislação de um país não admitir a apreensão no ato da importação, essa apreensão será substituída pela proibição de importação ou pela apreensão dentro do país.

6) Se a legislação de um país não admitir a apreensão no ato da importação nem a proibição de importação nem a apreensão dentro do país, enquanto a legislação não for modificada nesse sentido, essas medidas serão substituídas pelas ações e meios que a lei desse país assegurar em tais casos aos nacionais.

\section{Artigo 10}

1) As disposições do artigo precedente serão aplicáveis em caso de utilização direta ou indireta de uma falsa indicação relativa à procedência do produto ou à identidade do produtor, fabricante ou comerciante. 
2) Será, em qualquer caso, reconhecido como parte interessada, quer seja pessoa física ou jurídica, o produtor, fabricante ou comerciante empenhado na produção, fabricação ou comércio desse produto e estabelecido quer na localidade falsamente indicada como lugar de procedência, quer na região em que essa localidade estiver situada, quer no país falsamente indicado ou no país em que se fizer uso da falsa indicação de procedência.

\section{Artigo 10 bis}

1) Os países da União obrigam-se a assegurar aos nacionais dos países da União proteção efetiva contra a concorrência desleal.

2) Constitui ato de concorrência desleal qualquer ato de concorrência contrário aos usos honestos em matéria industrial ou comercial.

3) Deverão proibir-se particularmente:

1. todos os atos suscetíveis de, por qualquer meio, estabelecer confusão com o estabelecimento, os produtos ou a atividade industrial ou comercial de um concorrente;

2. as falsas alegações no exercício do comércio, suscetíveis de desacreditar o estabelecimento, os produtos ou a atividade industrial ou comercial de um concorrente;

3. as indicações ou alegações cuja utilização no exercício do comércio seja suscetível de induzir o público em erro sobre a natureza, modo de fabricação, características, possibilidades de utilização ou quantidade das mercadorias.

\section{Artigo 10 ter}

1) Os países da União se comprometem a assegurar aos nacionais dos outros países da União recursos legais apropriados à repressão eficaz de todos os atos mencionados nos Artigos 9,10 e 10 bis.

2) Comprometem-se, além disso, a prever medidas que permitam aos sindicatos e associações de industriais, produtores ou comerciantes interessados e cuja existência não for contrária às leis dos seus países, promover em juízo ou junto às autoridades administrativas a repressão dos atos previstos nos Artigos 9, 10 e 10 bis, na medida em que a lei do país em que a proteção é requerida o permite aos sindicatos e associações desse país.

\section{Artigo 11}

1) Os países da União, nos termos da sua lei interna, concederão proteção temporária às invenções patenteáveis, modelos de utilidade, desenhos ou modelos industriais, bem como às marcas de fábrica ou de comércio, para produtos que figurarem nas exposições internacionais oficiais ou reconhecidas oficialmente, organizadas no território de qualquer deles.

2) Essa proteção temporária não prolongará os prazos fixados no Artigo 4. Se, mais tarde, se invocar o direito de prioridade, a Administração de cada país poderá contar o prazo desde a data da apresentação do produto na exposição.

3) Cada país poderá exigir, para prova da identidade do objeto exposto e da data da apresentação, as provas que julgar necessárias.

\section{Artigo 12}

1) Cada um dos países da União se compromete a estabelecer um serviço especial da propriedade industrial e uma repartição central para informar o público sobre as patentes de invenção, modelos utilidade, desenhos ou modelos industriais e marcas de fábrica ou de comércio.

2) Esse serviço publicará um boletim periódico oficial. Publicará regularmente:

a) os nomes dos titulares das patentes concedidas, com uma breve descrição das invenções patenteadas;

b) as reproduções das marcas registradas. 


\section{Artigo 13}

1) a) A União tem uma Assembléia composta pelos países da União vinculados pelos Artigos 13 a 17.

b) O Governo de cada país é representado por um delegado, que pode ser assistido por suplentes, conselheiros e peritos.

c) As despesas de cada delegação correm por conta do Governo que a designou.

2) a) A Assembléia:

i) trata de todas as questões referentes à manutenção e desenvolvimento da União e à aplicação da presente Convenção;

ii) dá à Repartição Internacional da Propriedade Intelectual (a seguir denominada "a Repartição Internacional") mencionada na Convenção que institui a Organização Mundial da Propriedade Intelectual (a seguir denominada "a Organização") diretrizes referentes à preparação das conferências de revisão, levando em consideração as observações feitas pelos países da União que não vinculados pelos Artigos 13 a 17;

iii) examina e aprova os relatórios e as atividades do Diretor-Geral da Organização relativos à União e lhe dá todas as diretrizes úteis com referência às questões da competência da União;

iv) elege os membros da Comissão Executiva da Assembléia;

v) examina e aprova os relatórios $e$ as atividades de sua Comissão Executiva e lhe transmite diretrizes;

vi) fixa o programa, adota o orçamento trienal da União e aprova as suas contas de encerramento; vii) adota o regulamento financeiro da União;

viii) cria os comitês de peritos e grupos de trabalho que julgar úteis para a realização dos objetivos da União;

ix) decide quais são os países não membros da União e quais são as organizações intergovernamentais e internacionais não governamentais que podem ser admitidos às suas reuniões na qualidade de observadores;

x) aprova as modificações dos Artigos 13 a 17;

xi) promove qualquer outra ação apropriada com vista a atingir os objetivos da União;

xii) desempenha-se de quaisquer outras funções em que a presente Convenção implique;

xiii) exerce, sob reserva de os aceitar, os direitos que lhe são conferidos pela Convenção que institui a Organização.

b) A Assembléia delibera, após ter tomado conhecimento do parecer da Comissão de Coordenação da Organização, sobre as questões que interessam igualmente a outras Uniões administradas pela Organização.

3) a) Sob reserva das disposições do subparágrafo b) cada delegado só pode representar um país.

b) Os países da União, agrupados em virtude de um acordo particular num escritório comum que tenha para cada um deles a natureza de serviço nacional especial de propriedade industrial mencionado no Artigo 12, podem, no decorrer das discussões, ser representados conjuntamente por um deles.

4) a) Cada país membro da Assembléia tem direito a um voto.

b) O "quorum" é constituído por metade dos países membros da Assembléia.

c) Não obstante as disposições do subparágrafo b), se, durante uma sessão, o número de países representados for inferior à metade mas igual ou superior a um terço dos países membros da Assembléia, esta pode tomar decisões; todavia, as decisões da Assembléia, com exceção das que dizem respeito ao seu funcionamento, não se tornam executórias senão depois de satisfeitas as condições a seguir enunciadas. A Repartição Internacional comunica as referidas decisões aos países membros da Assembléia que não estavam representados, convidando-os a expressar, por escrito, no prazo de três meses a contar da data da comunicação, o seu voto ou a sua abstenção. As referidas decisões tornam-se executórias se, terminado esse prazo, o número dos países que deste modo exprimiram o seu voto ou a sua abstenção for, pelo menos, igual ao número de países que 
faltava para que o "quorum" tivesse sido atingido quando da sessão, contanto que, ao mesmo tempo, se obtenha a necessária maioria.

d) Sob reserva do disposto no Artigo 17.2, as decisões da Assembléia são tomadas por maioria de dois terços dos votos expressos.

e) A abstenção não é considerada voto.

5) a) Sob reserva do subparágrafo b), cada delegado não pode votar senão em nome de um único país.

b) Os países da União mencionados no parágrafo 3) b) esforçar-se-ão, de um modo geral, por se fazer representar, nas sessões da Assembléia, pelas suas próprias delegações. Todavia, se, por razões excepcionais, um dos países citados não se puder fazer representar pela sua própria delegação, pode dar à delegação de outro país o poder de votar em seu nome, entendendo-se que uma delegação não pode votar por procuração senão por um único país. Toda a procuração para este efeito deve ser objeto de documento assinado pelo Chefe do Estado ou pelo Ministro competente.

6) Os países da União que não sejam membros da Assembléia são admitidos às suas reuniões, na qualidade de observadores.

7) a) A Assembléia se reúne de três em três anos, em sessão ordinária, mediante convocação do Diretor-Geral e, salvo casos excepcionais, durante o mesmo período e no mesmo local que a Assembléia Geral da Organização.

b) A Assembléia reúne-se em sessão extraordinária, mediante convocação do Diretor-Geral, a pedido da Comissão Executiva, ou de um quarto dos países membros da Assembléia.

8) A Assembléia adota o seu regulamento interno.

\section{Artigo 14}

1) A Assembléia tem uma Comissão Executiva.

2) a) A Comissão Executiva é composta pelos países eleitos pela Assembléia dentre os países membros desta. Por outro lado, o país em cujo território a Organização tem a sua sede dispõe "exofficio" de um lugar na Comissão, sob reserva das disposições do artigo 16.7) b).

b) O Governo de cada país membro da Comissão Executiva é representado por um delegado que pode ser assistido por suplentes, conselheiros e peritos.

c) As despesas de cada delegação correm por conta do Governo que a designou.

3) O número de países membros da Comissão Executiva corresponde à quarta parte do número dos países membros da Assembléia. No cálculo dos lugares a preencher não é levado em consideração o que restar da divisão por quatro.

4) Quando da eleição dos membros da Comissão Executiva, a Assembléia levará em consideração uma distribuição geográfica eqüitativa e a necessidade para todos os países partes dos Acordos particulares estabelecidos em relação com a União de figurarem entre os países que constituem a Comissão Executiva.

5) a) Os membros da Comissão Executiva exercem o mandato a partir do encerramento da sessão da Assembléia no decurso da qual foram eleitos, até o fim da sessão ordinária seguinte da Assembléia.

b) Os membros da Comissão Executiva são reelegíveis no limite máximo de dois terços do seu total.

c) A Assembléia regulamenta as modalidades de eleição e de eventual reeleição dos membros da Comissão Executiva.

6) a) A Comissão Executiva:

i) prepara o projeto da ordem do dia da Assembléia;

ii) submete à Assembléia propostas relativas aos projetos de programa e de orçamento trienal da União, preparados pelo Diretor-Geral;

iii) pronuncia-se, dentro dos limites do programa e do orçamento trienal, sobre os programas $e$ orçamentos anuais preparados pelo Diretor-Geral; 
iv) submete à Assembléia, com os comentários apropriados, os relatórios periódicos do DiretorGeral e os relatórios anuais de verificação de contas;

v) toma todas as medidas úteis com vista à execução do programa da União pelo Diretor-Geral, em conformidade com as decisões da Assembléia e levando em consideração circunstâncias que sobrevenham entre duas sessões ordinárias de Assembléia;

iv) encarrega-se de quaisquer outras funções que lhe sejam atribuídas no âmbito da presente Convenção.

b) A Comissão Executiva decide, depois de tomar conhecimento do parecer da Comissão de Coordenação da Organização, sobre as questões que interessam igualmente a outras Uniões administradas pela Organização.

7) a) A Comissão Executiva se reúne uma vez por ano em sessão ordinária, mediante convocação do Diretor-Geral, tanto quanto possível durante o mesmo período e no mesmo lugar que a Comissão de Coordenação da Organização.

b) A Comissão Executiva se reúne em sessão extraordinária, mediante convocação do DiretorGeral, quer por iniciativa deste, quer a pedido do seu Presidente ou de um quarto dos seus membros.

8) a) Cada país membro da Comissão Executiva tem direito a um voto.

b) O "quorum" é constituído por metade dos países membros da comissão Executiva.

c) As decisões são tomadas por maioria simples dos votos expressos.

d) A abstenção não é considerada voto.

e) Cada delegado não pode representar senão um único país e pode votar apenas em nome deste.

9) Os países da União que não sejam membros da Comissão Executiva são admitidos às suas reuniões na qualidade de observadores.

10) A Comissão Executiva adota o seu regulamento interno.

\section{Artigo 15}

1) a) As tarefas administrativas da competência da União serão asseguradas pela Repartição Internacional, que sucederá à Secretaria da União reunida com a Secretaria da União instituída pela Convenção Internacional para a Proteção das Obras Literárias e Artísticas.

b) A Repartição Internacional assegurará principalmente o secretariado dos diversos órgãos da União.

c) O Diretor-Geral da Organização é o mais alto funcionário da União e a representa.

2) A Repartição Internacional reunirá e publicará as informações relativas à proteção da propriedade industrial. Cada país da União comunicará, logo que possível, à Repartição Internacional, o texto de qualquer lei nova, bem como todos os textos oficiais referentes à proteção da propriedade industrial. Fornecerá, ainda, à Repartição Internacional, todas as publicações dos seus serviços competentes em matéria de propriedade industrial que atinjam diretamente a proteção da propriedade industrial e sejam julgadas pela Repartição Internacional como de interesse para suas atividades.

3) A Repartição Internacional publicará um periódico mensal.

4) A Repartição Internacional fornecerá, a todos os países da União, a seu pedido, informações sobre as questões referentes à proteção da propriedade industrial.

5) A Repartição Internacional procederá a estudos e fornecerá serviços destinados a facilitar a proteção da propriedade industrial.

6) O Diretor-Geral e qualquer membro do pessoal designado por ele participarão, sem direito a voto, de todas as reuniões da Assembléia, da Comissão Executiva e de quaisquer outras comissões de peritos ou grupos de trabalho. O Diretor-Geral ou um membro do pessoal por ele designado é, "ex-officio", secretário desses órgãos.

7) a) A Repartição Internacional, segundo as diretrizes da Assembléia e em cooperação com a Comissão Executiva, prepara as conferências de revisão das disposições da Convenção, excluindo os Artigos 13 a 17. 
b) A Repartição Internacional pode consultar organizações intergovernamentais e internacionais não governamentais sobre a preparação das conferências de revisão.

c) O Diretor-Geral e as pessoas por ele designadas tomarão parte, sem direito a voto, nas deliberações destas conferências.

8) A Repartição Internacional executa todas as outras funções que lhe forem atribuídas.

\section{Artigo 16}

1) a) A União tem um orçamento.

b) O orçamento da União compreende as receitas e as despesas próprias da União, a sua contribuição para o orçamento das despesas comuns das Uniões, assim como, sendo necessário, a soma posta à disposição do orçamento da Conferência da Organização.

c) São consideradas como despesas das Uniões as despesas não atribuídas exclusivamente à União, mas igualmente a uma ou mais Uniões administradas pela Organização. A parte da União nessas despesas comuns é proporcional ao interesse que as mesmas têm para ela.

2) O orçamento da União é fixado levando em consideração as exigências de coordenação com os orçamentos das outras Uniões administrativas pela Organização.

3) O orçamento da União é financiado pelos seguintes recursos:

i) contribuições dos países da União;

ii) taxas e quantias devidas pelos serviços prestados pela Repartição Internacional no âmbito da União;

iii) o produto da venda das publicações da Repartição Internacional referente à União e os direitos relativos a estas publicações;

iv) doações, legados e subvenções;

v) aluguéis, juros e outros rendimentos diversos.

4) a) Para determinar a sua parte de contribuição no orçamento, cada país da União está incluído numa classe e paga as suas contribuições anuais na base de um número de unidades fixado como se segue:

Classe I 25

Classe II 20

Classe III 15

Classe IV 10

Classe V 5

Classe VI 3

Classe VII 1

b) A menos que o não tenha feito anteriormente, cada país indica, no momento do depósito do seu instrumento de ratificação ou de adesão, a classe na qual deseja ser incluído. Pode mudar de classe. Se escolher uma classe inferior, o país deve dar do fato conhecimento à Assembléia, quando de uma das suas sessões ordinárias. Tal alteração tem efeito no início do ano civil que se segue à referida sessão.

c) A contribuição anual de cada país consiste numa quantia em que a relação com a soma total das contribuições anuais para o orçamento da União de todos os países é a mesma que a relação existente entre o número de unidade da classe na qual cada país está incluído e o número total das unidades do conjunto dos países.

d) As contribuições são devidas no dia 10 de janeiro de cada ano.

e) O país que se atrasar no pagamento das suas contribuições não poderá exercer o seu direito de voto, em nenhum dos órgãos da União de que for membro, se a quantia em atraso for igual ou superior a das contribuições de que é devedor pelos dois anos anteriores completos. Tal país pode, todavia, ser autorizado a conservar o exercício do seu direito de voto no seio do referido órgão, enquanto este considerar que o atraso resulta de circunstâncias excepcionais e inevitáveis. 
f) No caso de o orçamento não ser aprovado antes do início de um novo exercício, será mantido nos mesmos níveis do orçamento do ano anterior, segundo as modalidades previstas pelo regulamento financeiro.

5) O montante das taxas e quantias devidas pelos serviços prestados pela Repartição Internacional com referência à União é fixado pelo Diretor-Geral, que comunicará à Assembléia e à Comissão Executiva.

6) a) A União possui um fundo de operações constituído por uma contribuição única efetuada por cada país da União. Se o fundo se tornar insuficiente, a Assembléia decidirá sobre seu aumento.

b) O montante da contribuição inicial de cada país para o fundo acima citado ou da sua participação no aumento deste é proporcional à contribuição desse país para o ano no decurso do qual o fundo for constituído, ou o aumento for decidido.

c) A proporção e modalidades de contribuição são fixadas pela Assembléia mediante proposta do Diretor-Geral e após o parecer da Comissão de Coordenação da Organização.

7) a) O acordo de sede concluído com o país em cujo território a Organização tem a sua sede prevê que, se o fundo de operações for insuficiente, este país concederá adiantamentos. O montante destes e as condições em que são concedidos serão objeto, em cada caso, de acordos particulares entre o país em causa e a Organização. Esse país dispõe "ex-officio" de um lugar na Comissão Executiva durante todo o período em que tiver de conceder adiantamentos.

b) O país mencionado no subparágrafo a) e a Organização têm, cada um, o direito de denunciar o compromisso de conceder adiantamentos, mediante notificação escrita. A denúncia tem efeito três anos após o fim do ano no decurso do qual foi notificada.

8) A auditoria das contas é assegurada, segundo as modalidades previstas pelo regulamento financeiro, por um ou vários países da União ou por auditores externos, que serão, com o seu consentimento, designados pela Assembléia.

\section{Artigo 17}

1) Podem ser apresentadas, por qualquer país membro da Assembléia, pela Comissão Executiva ou pelo Diretor-Geral, propostas de modificação dos Artigos 13, 14, 15, 16 e do presente artigo. Estas propostas são comunicadas por este último aos países membros da Assembléia pelo menos seis meses antes de serem submetidas ao exame da mesma.

2) Qualquer modificação dos artigos referidos no parágrafo 1) é adotada pela Assembléia. A adoção requer três quartos dos votos expressos. Todavia, qualquer modificação do Artigo 13 e do presente parágrafo requer quatro quintos dos votos expressos.

3) Qualquer modificação dos artigos referidos no parágrafo 1) entra em vigor após o recebimento, pelo Diretor-Geral, das notificações escritas de aceitação, efetuado em conformidade com as suas regras constitucionais respectivas, por parte dos três quartos dos países que eram membros da Assembléia no momento da modificação ter sido aprovada. Qualquer modificação dos referidos artigos assim aceita vincula todos os países membros da Assembléia no momento em que a modificação entrar em vigor, ou que dela se tornarem membros em data posterior, todavia, qualquer modificação que aumente as obrigações financeiras dos países da União vincula apenas aqueles que notificaram a sua aceitação da referida modificação.

\section{Artigo 18}

1) A presente Convenção será submetida a revisões, com vista a nela se introduzirem melhoramentos suscetíveis de aperfeiçoar o sistema da União.

2) Para esse fim, terão lugar conferências sucessivamente, num dos países da União, entre os delegados dos referidos países.

3) As modificações dos Artigos 13 a 17 são regidas pelas disposições do Artigo 17. 


\section{Artigo 19}

Fica entendido que os países da União se reservam o direito de, separadamente, celebrar entre eles acordos particulares para a proteção da propriedade industrial, contanto que esses acordos não contrariem as disposições da presente Convenção.

\section{Artigo 20}

1) a) Cada um dos países da União que assinou o presente Ato pode ratificá-lo e, se o não assinou, pode a ele aderir. Os instrumentos de ratificação e de adesão são depositados junto ao DiretorGeral.

b) Cada um dos países da União pode declarar, no seu instrumento de ratificação ou adesão, que a sua ratificação ou adesão não é aplicável:

i) aos Artigos 1 a 12; ou

ii) aos Artigos 13 a 17.

c) Cada um dos países da União que, de acordo com o subparágrafo b), excluiu dos efeitos da sua ratificação ou da sua adesão um dos grupos dos artigos visados no referido subparágrafo pode, a qualquer momento, posteriormente, declarar que estende os efeitos da sua ratificação ou da sua adesão a esse grupo de artigos. Tal declaração é depositada junto ao Diretor-Geral.

2) a) Os Artigos 1 a 12 entram em vigor, com referência aos dez primeiros países da União que depositaram instrumentos de ratificação ou de adesão, sem fazer a declaração permitida pelo parágrafo 1) b) i), três meses após o depósito do décimo desses instrumentos de ratificação ou de adesão.

b) Os Artigos 13 a 17 entram em vigor, com referência aos dez primeiros países da União que depositaram instrumentos de ratificação ou de adesão, sem fazer a declaração permitida pelo parágrafo 1) b) ii), três meses após o depósito do décimo desses instrumentos de ratificação ou de adesão.

c) Sob reserva da entrada em vigor inicial, de acordo com as disposições dos subparágrafos a) e b), de cada um dos dois grupos de artigos referidos no parágrafo 1) b) i) e ii) e sob reserva das disposições do parágrafo 1) b), os Artigos 1 a 17 entram em vigor com relação a qualquer país da União, com exceção dos mencionados nos subparágrafos a) e b), que depositar um instrumento de ratificação ou de adesão, assim como em relação a qualquer país da União que depositar a declaração prevista no parágrafo 1) c), três meses após a data da notificação, pelo Diretor-Geral, de tal depósito a menos que uma data posterior tenha sido indicada no instrumento ou declaração depositado. Neste último caso, o presente Ato entra em vigor, em relação a esse país, na data assim indicada.

3) Com referência a cada país da União que depositar um instrumento de ratificação ou de adesão, os Artigos 18 a 30 entram em vigor na primeira data em que qualquer dos grupos de artigos referidos no parágrafo 1) b) entre em vigor em relação a esse país, de acordo com o parágrafo 2) a), b) ou c).

\section{Artigo 21}

1) Qualquer país estranho à União pode aderir ao presente Ato e tornar-se, por este fato, membro da União. Os instrumentos de adesão serão depositados junto ao Diretor-Geral.

2) a) Em relação a qualquer país estranho à União que tenha depositado seu instrumento de adesão pelo menos um mês antes da data da entrada em vigor das disposições do presente Ato, este entra em vigor na data em que as disposições entraram em vigor pela primeira vez, na forma do Artigo 20.2) a) ou b), a menos que uma data posterior tenha sido indicada no instrumento de adesão; todavia:

i) se os Artigos 1 a 12 não entraram em vigor nessa data, tal país ficará vinculado, durante o período intermediário anterior à entrada em vigor destas disposições, e em sua substituição pelos Artigos 1 a 12 do Ato de Lisboa; 
ii) se os Artigos 13 a17 não entraram em vigor nessa data, tal país ficará vinculado, durante o período intermediário anterior à entrada em vigor destas disposições, e em sua substituição pelos Artigos 13 e 14.3), 4) e 5) do Ato de Lisboa.

Se um país indicar uma data posterior no seu instrumento de adesão, o presente Ato entrará em vigor, em relação a esse país, na data assim indicada.

b) Em relação a qualquer país estranho à União que tenha depositado seu instrumento de adesão em data posterior à entrada em vigor de um só grupo de artigos do presente Ato ou em data que a precedeu de, pelo menos, um mês, o presente Ato entrará em vigor, sob reserva do previsto no subparágrafo a), três meses após a data em que a sua adesão foi notificada pelo Diretor-Geral, a menos que uma data posterior tenha sido indicada no instrumento de adesão. Neste último caso, o presente Ato entrará em vigor, em relação a esse país, na data assim indicada.

3) Em relação a qualquer país estranho à União que depositar seu instrumento de adesão após a data da entrada em vigor do presente Ato na sua totalidade, ou menos de um mês antes dessa data, o presente Ato entrará em vigor três meses depois da data em que a sua adesão foi notificada pelo Diretor-Geral, a menos que uma data posterior tenha sido indicada no instrumento de adesão. Neste último caso, o presente Ato entrará em vigor, em relação a esse país, na data assim indicada.

\section{Artigo 22}

Sob reserva das exceções possíveis previstas nos Artigos 20.1) b) e 28.2), a ratificação ou adesão implica, de pleno direito, acessão a todas as cláusulas e admissão a todas as vantagens estipuladas pelo presente Ato.

\section{Artigo 23}

Após a entrada em vigor do presente Ato na sua totalidade, nenhum país pode aderir a Atos anteriores à presente Convenção.

\section{Artigo 24}

1) Qualquer país pode declarar no seu instrumento de ratificação ou de adesão, ou pode informar o Diretor-Geral, por escrito, a qualquer momento, posteriormente, que a presente Convenção é aplicável a todo ou a parte dos territórios designados na declaração ou na notificação, dos quais assume a responsabilidade das relações exteriores.

2) Qualquer país que tenha feito tal declaração ou efetuado tal notificação pode, a todo o momento, notificar o Diretor-Geral de que a presente Convenção deixa de ser aplicável a todo ou parte desses territórios.

3) a) Qualquer declaração feita nos termos do parágrafo 1) tem efeito na mesma data que a ratificação ou adesão em cujo instrumento foi incluída e qualquer notificação efetuada nos termos deste parágrafo tem efeito três meses após a sua notificação pelo Diretor-Geral.

b) Qualquer notificação efetuada nos termos do parágrafo 2) tem efeito doze meses após seu recebimento pelo Diretor-Geral.

\section{Artigo 25}

1) Qualquer país parte da presente Convenção compromete-se a adotar, de acordo com a sua Constituição, as medidas necessárias para assegurar a aplicação da presente Convenção.

2) Entende-se que, no momento em que um país deposita o seu instrumento de ratificação ou de adesão, está em condições, em conformidade com a sua legislação interna, de tornar efetivas as disposições da presente Convenção.

\section{Artigo 26}

1) A presente Convenção permanece em vigor por tempo ilimitado.

2) Qualquer país pode denunciar o presente Ato por notificação dirigida ao Diretor-Geral. Esta denúncia implica também a denúncia de todos os Atos anteriores e apenas tem efeito em relação ao 
país que a efetuou, continuando a Convenção em vigor e executória com referência aos outros países da União.

3) A denúncia tem efeito um ano após o dia em que o Diretor-Geral recebeu a notifição.

4) A faculdade de denúncia prevista no presente artigo não pode ser exercida por nenhum país antes de expirar um prazo de cinco anos a contar da data em que se tornou membro da União.

\section{Artigo 27}

1) O presente Ato substitui, nas relações entre os países aos quais se aplica, e na medida em que se aplica, a Convenção de Paris de 20 de março de 1883 e os Atos de revisão subseqüentes.

2) a) Em relação aos países a que o presente Ato não é aplicável, ou não é aplicável na sua totalidade, mas aos quais é aplicável o Ato de Lisboa de 31 de outubro de 1958, continua este em vigor na sua totalidade ou na medida em que o presente Ato não o substitui em virtude do parágrafo 1).

b) Da mesma forma, em relação aos países aos quais nem o presente Ato, nem partes deste, nem o Ato de Lisboa são aplicáveis, continua em vigor o Ato de Londres de 2 de junho de 1934 na sua totalidade, ou na medida em que o presente Ato não o substitui, em virtude do parágrafo 1).

c) Da mesma forma, em relação aos países aos quais nem o presente Ato, nem partes deste, nem o Ato de Lisboa, nem o Ato de Londres são aplicáveis, mantém-se em vigor o Ato de Haia de 6 de novembro de 1925, na sua totalidade, ou na medida em que o presente Ato não o substitui, em virtude do parágrafo 1).

3) Os países estranhos à União que se tornarem partes do presente Ato aplicá-lo-ão em relação a qualquer país da União que não seja parte deste Ato ou que, sendo parte, tenha efetuado a declaração prevista no Artigo 20.1) b) i). Os referidos países admitem que tal país da União aplique nas suas relações com eles as disposições do Ato mais recente do qual é parte.

\section{Artigo 28}

1) Qualquer controvérsia entre dois ou mais países da União, relativa à interpretação ou à aplicação da presente Convenção que não seja solucionada por negociações, pode ser levada por qualquer dos países em causa perante o Tribunal Internacional de Justiça, mediante petição, de acordo com o Estatuto do Tribunal, a menos que os países em causa acordem sobre outro modo de solução. A Repartição Internacional será informada da controvérsia submetida ao Tribunal pelo país requerente; dará conhecimento disso aos outros países da União.

2) Qualquer país poderá, no momento em que assinar o presente Ato ou depositar o seu instrumento de ratificação ou de adesão, declarar que não se considera vinculado pelas disposições do parágrafo 1). No que se refere a qualquer controvérsia entre tal país e outro qualquer da União, não são aplicáveis as disposições do parágrafo 1).

3) Qualquer país que tiver feito a declaração prevista no parágrafo 2) pode, a todo o momento, retirá-la, mediante notificação dirigida ao Diretor-Geral.

\section{Artigo 29}

1) a) O presente Ato é assinado em um só exemplar em língua francesa e depositado junto ao Governo da Suécia.

b) Serão estabelecidos textos oficiais pelo Diretor-Geral, depois de consultados os Governos interessados, nas línguas alemã, inglesa, espanhola, italiana, portuguesa e russa e nas outras línguas que a Assembléia possa indicar.

c) Em caso de conflito sobre a interpretação dos diversos textos, faz fé o texto francês.

2) O presente Ato fica aberto para assinatura, em Estocolmo, até o dia 13 de janeiro de 1968.

3) O Diretor-Geral enviará aos Governos de todos os países da União e, sendo solicitado, ao Governo de qualquer outro, duas cópias autenticadas pelo Governo da Suécia do texto assinado do presente Ato. 
4) O Diretor-Geral fará registrar o presente Ato junto ao Secretário da Organização das Nações Unidas.

5) O Diretor-Geral notificará os Governos de todos os países da União das assinaturas, dos depósitos dos instrumentos de ratificação ou de adesão e de declarações compreendidas nestes instrumentos ou efetuadas em aplicação do Artigo 20.1) c), a entrada em vigor de todas as aplicações do presente Ato, as notificações de denúncia e as notificações feitas em aplicação do Artigo 24.

\section{Artigo 30}

1) Até a entrada em funções do primeiro Diretor-Geral, as referências no presente Ato à Repartição Internacional da Organização ou ao Diretor-Geral são consideradas como referindo-se, respectivamente, à Secretaria da União ou ao seu Diretor.

2) Os países da União que não estejam vinculados pelos Artigos 13 a 17 poderão, durante cinco anos após a entrada em vigor da Convenção que institui a Organização, exercer, se quiserem, os direitos previstos pelos Artigos 13 a 17 do presente Ato, como se estivessem vinculados por estes artigos. Qualquer país que pretenda exercer os referidos direitos depositará para esse fim junto ao Diretor-Geral uma notificação escrita que terá efeito na data do seu recebimento. Tais países serão considerados membros da Assembléia até expiração do referido período.

3) Enquanto não se tiverem tornado membros da Organização todos os países da União, a Repartição Internacional da Organização agirá igualmente como Secretaria da União e o DiretorGeral como Diretor desta Secretaria.

4) Quando todos os países da União se tornarem membros da Organização, os direitos, obrigações e bens da Secretaria da União passarão à Repartição Internacional da Organização.

Em fé do que os abaixo assinados, devidamente autorizados para esse fim, assinaram o presente Ato.

Feito em Estocolmo a 14 de julho de 1967.

Este texto não substitui o original publicado no Diário Oficial da União - Seção 1 de 10/04/1975

\section{Publicação:}

- Diário Oficial da União - Seção 1 - 10/4/1975, Página 4114 (Publicação Original)

- $\quad$ Coleção de Leis do Brasil - 1975, Página 42 Vol. 4 (Publicação Original) 


\section{DECRETO No 1.355, DE 30 DE DEZEMBRO DE 1994}

Promulga a Ata Final que Incorpora os Resultados da Rodada Uruguai de Negociações Comerciais Multilaterais do GATT.

O PRESIDENTE DA REPÚBLICA, no uso de suas atribuições, e

Considerando que o Congresso Nacional aprovou, pelo Decreto Legislativo $\mathrm{n}^{\circ}$ 30, de 15 de dezembro de 1994, a Ata Final que Incorpora aos Resultados da Rodada Uruguai de Negociações Comerciais Multilaterais do GATT, assinada em Maraqueche, em 12 de abril de 1994;

Considerando que o Instrumento de Ratificação da referida Ata Final pela República Federativa do Brasil foi depositado em Genebra, junto ao Diretor do GATT, em 21 de dezembro de 1994;

Considerando que a referida Ata Final entra em vigor para a República Federativa do Brasil em $1^{\circ}$ de janeiro de 1995,

\section{DECRETA:}

Art. $1^{\circ}$ A Ata Final que Incorpora os Resultados da Rodada Uruguai de Negociações Comerciais Multilaterais do GATT, apensa por cópia ao presente Decreto, será executada e cumprida tão inteiramente como nele contém.

Art. $2^{\circ}$ Este Decreto entra em vigor na data de sua publicação, revogadas as disposições em contrário.

Brasília, 30 de dezembro de 1994; $173^{\circ}$ da Independência e $106^{\circ}$ da República.

ITAMAR FRANCO

Celso Luiz Nunes Amorim

ACORDO SOBRE ASPECTOS DOS DIREITOS DE PROPRIEDADE INTELECTUAL RELACIONADOS AO COMÉRCIO ÍNDICE PARTE I DISPOSIÇÕES GERAIS E PRINCÍPIOS BÁSICOS PARTE II PADRÕES RELATIVOS À EXISTÊNCIA, ABRANGÊNCIA E EXERCÍCIO DE DIREITOS DE PROPRIEDADE INTELECTUAL

1.Direito do Autor e Direitos Conexos;

2.Marcas;

3.Indicações Geográficas;

4.Desenhos Industriais;

5.Patentes;

6.Topografias de Circuitos Integrados;

7.Proteção de Informação Confidencial; e

8.Controle de Práticas de Concorrência Desleal em Contratos de Licenças. 


\title{
PARTE III APLICAÇÃO DE NORMAS DE PROTEÇÃO DOS DIREITOS DE
} PROPRIEDADE INTELECTUAL

\author{
1.Obrigações Gerais;
}

2.Procedimentos e Remédios Civis e Administrativos;

3.Medidas Cautelares;

4.Exigência Especiais Relativas a Medidas de Fronteira; e

5.Procedimentos Penais.

PARTE IV OBTENÇÃO E MANUTENÇÃO DE DIREITOS DE PROPRIEDADE INTELECTUAL E PROCEDIMENTOS INTER-PARTES CONEXOS PARTE V PREVENÇÃO E SOLUÇÃO DE CONTROVÉRSIAS PARTE VI ARRANJOS TRANSITÓRIOS PARTE VII ARRANJOS INSTITUCIONAIS; DISPOSIÇÕES FINAIS ACORDO SOBRE ASPECTOS DOS DIREITOS DE PROPRIEDADE INTELECTUAL RELACIONADOS AO COMÉRCIO

Os Membros, Desejando reduzir distorções e obstáculos ao comércio internacional e levando em consideração a necessidade de promover uma proteção eficaz e adequada dos direitos de propriedade intelectual e assegurar que as medidas e procedimentos destinados a fazê-los respeitar não se tornem, por sua vez, obstáculos ao comércio legítimo; Reconhecendo, para tanto, a necessidade de novas regras e disciplinas relativas:

a) à aplicabilidade dos princípios básicos do GATT 1994 e dos acordos e convenções internacionais relevantes em matéria de propriedade intelectual;

b) ao estabelecimento de padrões e princípios adequados relativos à existência, abrangência e exercício de direitos de propriedade intelectual relacionados ao comércio;

c) ao estabelecimento de meios eficazes e apropriados para a aplicação de normas de proteção de direitos de propriedade intelectual relacionados ao comércio, levando em consideração as diferenças existentes entre os sistemas jurídicos nacionais;

d) ao estabelecimento de procedimentos eficazes e expeditos para a prevenção e solução multilaterais de controvérsias entre Governos; e

e) às disposições transitórias voltadas à plena participação nos resultados das negociações;

Reconhecendo a necessidade de um arcabouço de princípios, regras e disciplinas multilaterais sobre o comércio internacional de bens contrafeitos;

Reconhecendo que os direitos de propriedade intelectual são direitos privados;

Reconhecendo os objetivos básicos de política pública dos sistemas nacionais para a proteção da propriedade intelectual, inclusive os objetivos de desenvolvimento e tecnologia;

Reconhecendo igualmente as necessidades especiais dos países de menor desenvolvimento relativo Membros no que se refere à implementação interna de leis e regulamentos com a máxima flexibilidade, de forma a habilitá-los a criar uma base tecnológica sólida e viável;

Ressaltando a importância de reduzir tensões mediante a obtenção de compromissos firmes para a solução de controvérsias sobre questões de propriedade intelectual relacionadas ao comércio, por meio de procedimentos multilaterais;

Desejando estabelecer relações de cooperação mútua entre a OMC e a Organização Mundial da Propriedade Intelectual (denominada neste Acordo como OMPI), bem como com outras organizações internacionais relevantes; 
Acordam, pelo presente, o que se segue:

\section{PARTE I}

\section{DISPOSIÇÕES GERAIS E PRINCÍPIOS BÁSICOS ARTIGO}

1. Natureza e Abrangência das Obrigações 1. Os Membros colocarão em vigor o disposto neste Acordo. Os Membros poderão, mas não estarão obrigados a prover, em sua legislação, proteção mais ampla que a exigida neste Acordo, desde que tal proteção não contrarie as disposições deste Acordo. Os Membros determinarão livremente a forma apropriada de implementar as disposições deste Acordo no âmbito de seus respectivos sistema e prática jurídicos.

2. Para os fins deste Acordo, o termo "propriedade intelectual" refere-se a todas as categorias de propriedade intelectual que são objeto das Seções 1 a 7 da Parte II.

3. Os Membros concederão aos nacionais de outros Membros o tratamento previsto neste Acordo. No que concerne ao direito de propriedade intelectual pertinente, serão considerados nacionais de outros Membros as pessoas físicas ou jurídicas que atendam aos critérios para usufruir da proteção prevista estabelecidos na Convenção de Paris (1967), na Convenção de Berna (1971), na Convenção de Roma e no Tratado sobre Propriedade Intelectual em Matéria de Circuitos Integrados, quando todos Membros do Acordo Constitutivo da OMC forem Membros dessas Convenções. Todo Membro que faça uso das possibilidades estipuladas no parágrafo 3 do Artigo 5 ou no parágrafo 2 do Artigo 6 da Convenção de Roma fará uma notificação, segundo previsto naquelas disposições, ao Conselho para os Aspectos dos Direitos de Propriedade Intelectual Relacionados ao Comércio (o "Conselho para TRIPS").

\section{ARTIGO 2}

Convenções sobre Propriedade Intelectual

1. Com relação às Partes II, III e IV deste Acordo, os Membros cumprirão o disposto nos Artigos 1 a 12, e 19, da Convenção de Paris (1967).

2. Nada nas Partes I a IV deste Acordo derrogará as obrigações existentes que os Membros possam ter entre si, em virtude da Convenção de Paris, da Convenção de Berna, da Convenção de Roma e do Tratado sobre a Propriedade Intelectual em Matéria de Circuitos Integrados.

\section{ARTIGO 3}

\section{Tratamento Nacional}

1. Cada Membro concederá aos nacionais dos demais Membros tratamento não menos favorável que o outorgado a seus próprios nacionais com relação à proteção da propriedade intelectual, salvo as exceções já previstas, respectivamente, na Convenção de Paris (1967), na Convenção de Berna (1971), na Convenção de Roma e no Tratado sobre Propriedade Intelectual em Matéria de Circuitos Integrados. No que concerne a artistas-intérpretes, produtores de fonogramas e organizações de radiodifusão, essa obrigação se aplica apenas aos direitos previstos neste Acordo. Todo Membro que faça uso das possibilidades previstas no Artigo 6 da Convenção de Berna e no parágrafo 1 (b) do Artigo 16 da Convenção de Roma fará uma notificação, de acordo com aquelas disposições, ao Conselho para TRIPS.

2. Os Membros poderão fazer uso das exceções permitidas no parágrafo 1 em relação a procedimentos judiciais e administrativos, inclusive a designação de um endereço de serviço ou a nomeação de um agente em sua área de jurisdição, somente quando tais exceções sejam necessárias para assegurar o cumprimento de leis e regulamentos que não sejam incompatíveis com as disposições deste Acordo e quando tais práticas não sejam aplicadas de maneira que poderiam constituir restrição disfarçada ao comércio. 


\section{ARTIGO 4}

\section{Tratamento de Nação Mais Favorecida}

Com relação à proteção da propriedade intelectual, toda vantagem, favorecimento, privilégio ou imunidade que um Membro conceda aos nacionais de qualquer outro país será outorgada imediata e incondicionalmente aos nacionais de todos os demais Membros. Está isenta desta obrigação toda vantagem, favorecimento, privilégio ou imunidade concedida por um Membro que:

a) resulte de acordos internacionais sobre assistência judicial ou sobre aplicação em geral da lei e não limitados em particular à proteção da propriedade intelectual;

b) tenha sido outorgada em conformidade com as disposições da Convenção de Berna (1971) ou da Convenção de Roma que autorizam a concessão tratamento em função do tratamento concedido em outro país e não do tratamento nacional;

c) seja relativa aos direitos de artistas-intérpretes, produtores de fonogramas e organizações de radiodifusão não previstos neste Acordo;

d) resultem de Acordos internacionais relativos à proteção da propriedade intelectual que tenham entrado em vigor antes da entrada em vigor do Acordo Constitutivo da OMC, desde que esses acordos sejam notificados ao Conselho para TRIPS e não constituam discriminação arbitrária ou injustificável contra os nacionais dos demais Membros.

\section{ARTIGO 5}

Acordos Multilaterais sobre Obtenção ou Manutenção da Proteção

As obrigações contidas nos Artigos 3 e 4 não se aplicam aos procedimentos previstos em acordos multilaterais concluídos sob os auspícios da OMPI relativos à obtenção e manutenção dos direitos de propriedade intelectual.

\section{ARTIGO 6}

Exaustão

Para os propósitos de solução de controvérsias no marco deste Acordo, e sem prejuízo do disposto nos Artigos 3 e 4, nada neste Acordo será utilizado para tratar da questão da exaustão dos direitos de propriedade intelectual.

\section{ARTIGO 7}

\section{Objetivos}

A proteção e a aplicação de normas de proteção dos direitos de propriedade intelectual devem contribuir para a promoção da inovação tecnológica e para a transferência e difusão de tecnologia, em benefício mútuo de produtores e usuários de conhecimento tecnológico e de uma forma conducente ao bem-estar social econômico e a um equilíbrio entre direitos e obrigações.

\section{ARTIGO 8}

\section{Princípios}

1. Os Membros, ao formular ou emendar suas leis e regulamentos, podem adotar medidas necessárias para proteger a saúde e nutrição públicas e para promover o interesse público em setores de importância vital para seu desenvolvimento sócio-econômico e tecnológico, desde que estas medidas sejam compatíveis com o disposto neste Acordo.

2. Desde que compatíveis com o disposto neste Acordo, poderão ser necessárias medidas apropriadas para evitar o abuso dos direitos de propriedade intelectual por seus titulares ou para evitar o recurso a práticas que limitem de maneira injustificável o comércio ou que afetem adversamente a transferência internacional de tecnologia. 


\section{PARTE II}

\section{NORMAS RELATIVAS À EXISTÊNCIA, ABRANGÊNCIA E EXERCÍCIO DOS DIREITOS DE PROPRIEDADE INTELECTUAL}

\section{SEÇÃO 1: DIREITO DO AUTOR E DIREITOS CONEXOS}

\section{ARTIGO 9}

\section{Relação com a Convenção de Berna}

1. Os Membros cumprirão o disposto nos Artigos 1 a 21 e no Apêndice da Convenção de Berna (1971). Não obstante, os Membros não terão direitos nem obrigações, neste Acordo, com relação aos direitos conferidos pelo Artigo 6bis da citada Convenção, ou com relação aos direitos dela derivados. 2. A proteção do direito do autor abrangerá expressões e não idéias, procedimentos, métodos de operação ou conceitos matemáticos como tais.

\section{ARTIGO 10}

Programas de Computador e Compilações de Dados 1. Programas de computador, em código fonte ou objeto, serão protegidos como obras literárias pela Convenção de Berna (1971).

2. As compilações de dados ou de outro material, legíveis por máquina ou em outra forma, que em função da seleção ou da disposição de seu conteúdo constituam criações intelectuais, deverão ser protegidas como tal. Essa proteção, que não se estenderá aos dados ou ao material em si, se dará sem prejuízo de qualquer direito autoral subsistente nesses dados material.

\section{ARTIGO 11}

Direitos de Aluguel

Um Membro conferirá aos autores e a seus sucessores legais, pelo menos no que diz respeito a programas de computador e obras cinematográficas, o direito de autorizar ou proibir o aluguel público comercial dos originais ou das cópias de suas obras protegidas pelo direito do autor. Um Membro estará isento desta obrigação no que respeita a obras cinematográficas, a menos que esse aluguel tenha dado lugar a uma ampla copiagem dessas obras, que comprometa significativamente o direito exclusivo de reprodução conferido por um Membro aos autores e seus sucessores legais. Com relação aos programas de computador, esta obrigação não se aplica quando o programa em si não constitui o objeto essencial do aluguel.

\section{ARTIGO 12}

Duração da proteção

Quando a duração da proteção de uma obra, que não fotográfica ou de arte aplicada, for calculada em base diferente à da vida de uma pessoa física, esta duração não será inferior a 50 anos, contados a partir do fim do ano civil da publicação autorizada da obra ou, na ausência dessa publicação autorizada nos 50 anos subseqüentes à realização da obra, a 50 anos, contados a partir do fim do ano civil de sua realização.

\section{ARTIGO 13}

\section{Limitações e Exceções}

Os Membros restringirão as limitações ou exceções aos direitos exclusivos a determinados casos especiais, que não conflitem com a exploração normal da obra e não prejudiquem injustificavelmente os interesses legítimos do titular do direito.

\section{ARTIGO 14}

Proteção de Artistas-Intérpretes, Produtores de Fonogramas (Gravações Sonoras) e Organizações de Radiodifusão 
1. No que respeita à fixação de suas apresentações em fonogramas, os artistas-intérpretes terão a possibilidade de evitar a fixação de sua apresentação não fixada e a reprodução desta fixação, quando efetuadas sem sua autorização. Os artistas-intérpretes terão também a possibilidade de impedir a difusão por meio de transmissão sem fio e a comunicação ao público de suas apresentações ao vivo, quando efetuadas sem sua autorização.

2. Os produtores de fonogramas gozarão do direito de autorizar ou proibir a reprodução direta ou indireta de seus fonogramas.

3. As organizações de radiodifusão terão o direito de proibir a fixação, a reprodução de fixações e a retransmissão por meios de difusão sem fio, bem como a comunicação ao público de suas transmissões televisivas, quando efetuadas sem sua autorização. Quando não garantam esses direitos às organizações de radiodifusão, os Membros concederão aos titulares do direito de autor, nas matérias objeto das transmissões, a possibilidade de impedir os atos antes mencionados, sujeitos às disposições da Convenção de Berna (1971).

4. As disposições do Artigo 11 relativas a programas de computador serão aplicadas mutatis mutandis aos produtores de fonogramas e a todos os demais titulares de direitos sobre fonogramas, segundo o determinado pela legislação do Membro. Se, em 15 de abril de 1994, um Membro tiver em vigor um sistema eqüitativo de remuneração dos titulares de direitos no que respeita ao aluguel de fonogramas, poderá manter esse sistema desde que o aluguel comercial de fonogramas não esteja causando prejuízo material aos direitos exclusivos de reprodução dos titulares de direitos.

5. A duração da proteção concedida por este Acordo aos artistas-intérpretes e produtores de fonogramas se estenderá pelo menos até o final de um prazo de 50 anos, contados a partir do final do ano civil no qual a fixação tenha sido feita ou a apresentação tenha sido realizada. A duração da proteção concedida de acordo com o parágrafo 3 será de pelo menos 20 anos, contados a partir do fim do ano civil em que a transmissão tenha ocorrido.

6. Todo Membro poderá, em relação aos direitos conferidos pelos parágrafos 1 , 2 e 3, estabelecer condições, limitações, exceções e reservas na medida permitida pela Convenção de Roma. Não obstante, as disposições do Artigo 18 da Convenção de Berna(1971) também serão aplicadas, mutatis mutandis, aos direitos sobre os fonogramas de artistas-intérpretes e produtores de fonogramas.

SEÇÃO 2:

\section{MARCAS}

\section{ARTIGO 15}

\section{Objeto da Proteção}

1. Qualquer sinal, ou combinação de sinais, capaz de distinguir bens e serviços de um empreendimento daqueles de outro empreendimento, poderá constituir uma marca. Estes sinais, em particular palavras, inclusive nomes próprios, letras, numerais, elementos figurativos e combinação de cores, bem como qualquer combinação desses sinais, serão registráveis como marcas. Quando os sinais não forem intrinsecamente capazes de distinguir os bens e serviços pertinentes, os Membros poderão condicionar a possibilidade do registro ao caráter distintivo que tenham adquirido pelo seu uso. Os Membros poderão exigir, como condição para registro, que os sinais sejam visualmente perceptíveis.

2. O disposto no parágrafo 1 não será entendido como impedimento a que um Membro denegue o registro de uma marca por outros motivos, desde que estes não infrinjam as disposições da Convenção de Paris (1967).

3. Os Membros poderão condicionar a possibilidade do registro ao uso da marca. Não obstante, o uso efetivo de uma marca não constituirá condição para a apresentação de pedido de registro. Uma solicitação de registro não será indeferida apenas com base no fato de que seu uso pretendido não tenha ocorrido antes de expirado um prazo de três anos, contados a partir da data da solicitação. 
4. A natureza dos bens ou serviços para os quais se aplique uma marca não constituíra, em nenhum caso, obstáculo a seu registro.

5. Os Membros publicarão cada marca antes ou prontamente após o seu registro e concederão oportunidade razoável para o recebimento de pedidos de cancelamento do registro. Ademais, os Membros poderão oferecer oportunidade para que o registro de uma marca seja contestado.

ARTIGO 16

Direitos Conferidos

1. O titular de marca registrada gozará do direito exclusivo de impedir que terceiros, sem seu consentimento, utilizem em operações comerciais sinais idênticos ou similares para bens ou serviços que sejam idênticos ou similares àqueles para os quais a marca está registrada, quando esse uso possa resultar em confusão. No caso de utilização de um sinal idêntico para bens e serviços idênticos presumir-se-á uma possibilidade de confusão. Os direitos descritos acima não prejudicarão quaisquer direitos prévios existentes, nem afetarão a possibilidade dos Membros reconhecerem direitos baseados no uso.

2. O disposto no Artigo 6bis da Convenção de Paris (1967) aplicar-se-á, mutatis mutandis, a serviços. Ao determinar se uma marca é notoriamente conhecida, os Membros levarão em consideração o conhecimento da marca no setor pertinente do público, inclusive o conhecimento que tenha sido obtido naquele Membro, como resultado de promoção da marca.

3. O disposto no Artigo 6bis da Convenção de Paris (1967)aplicar-se-á, mutatis mutandis, aos bens e serviços que não sejam similares àqueles para os quais uma marca esteja registrada, desde que o uso dessa marca, em relação àqueles bens e serviços, possa indicar uma conexão entre aqueles bens e serviços e o titular da marca registrada e desde que seja provável que esse uso prejudique os interesses do titular da marca registrada.

\section{ARTIGO 17}

\section{Exceções}

Os Membros poderão estabelecer exceções limitadas aos direitos conferidos para uma marca, tal como o uso adequado de termos descritivos, desde que tais exceções levem em conta os legítimos interesses do titular da marca e de terceiros.

\section{ARTIGO 18}

Duração da Proteção

O registro inicial de uma marca, e cada uma das renovações do registro, terá duração não inferior a sete anos. O registro de uma marca será renovável indefinidamente.

\section{ARTIGO 19}

\section{Requisito do Uso}

1. Se sua manutenção requer o uso da marca, um registro só poderá ser cancelado após transcorrido um prazo ininterrupto de pelo menos três anos de não-uso, a menos que o titular da marca demonstre motivos válidos, baseados na existência de obstáculos a esse uso. Serão reconhecidos como motivos válidos para o não-uso circunstâncias alheias à vontade do titular da marca, que constituam um obstáculo ao uso da mesma, tais como restrições à importação ou outros requisitos oficiais relativos aos bens e serviços protegidos pela marca.

2. O uso de uma marca por outra pessoa, quando sujeito ao controle de seu titular, será reconhecido como uso da marca para fins de manutenção do registro. 


\section{ARTIGO 20}

\section{Outros Requisitos}

O uso comercial de uma marca não será injustificavelmente sobrecarregado com exigências especiais, tais como o uso com outra marca, o uso em uma forma especial ou o uso em detrimento de sua capacidade de distinguir os bens e serviços de uma empresa daqueles de outra empresa. Esta disposição não impedirá uma exigência de que uma marca que identifique a empresa produtora de bens e serviços seja usada juntamente, mas não vinculadamente, com a marca que distinga os bens e serviços específicos em questão daquela empresa. A

\section{RTIGO 21}

\section{Licenciamento e Cessão}

Os Membros poderão determinar as condições para a concessão de licenças de uso e cessão de marcas, no entendimento de que não serão permitidas licenças compulsórias e que o titular de uma marca registrada terá o direito de ceder a marca, com ou sem a transferência do negócio ao qual a marca pertença.

SEÇÃO 3:

\section{INDICAÇÕES GEOGRÁFICAS}

\section{ARTIGO 22}

\section{Proteção das Indicações Geográficas}

1. Indicações Geográficas são, para os efeitos deste Acordo, indicações que identifiquem um produto como originário do território de um Membro, ou região ou localidade deste território, quando determinada qualidade, reputação ou outra característica do produto seja essencialmente atribuída à sua origem geográfica.

2. Com relação às indicações geográficas, os Membros estabelecerão os meios legais para que as partes interessadas possam impedir: a) a utilização de qualquer meio que, na designação ou apresentação do produto, indique ou sugira que o produto em questão provém de uma área geográfica distinta do verdadeiro lugar de origem, de uma maneira que conduza o público a erro quanto à origem geográfica do produto; b) qualquer uso que constitua um ato de concorrência desleal, no sentido do disposto no artigo 10bis da Convenção de Paris(1967).

3. Um Membro recusará ou invalidará, ex officio, se sua legislação assim o permitir, ou a pedido de uma parte interessada o registro de uma marca que contenha ou consista em indicação geográfica relativa a bens não originários do território indicado, se o uso da indicação na marca para esses bens for de natureza a induzir o público a erro quanto ao verdadeiro lugar de origem.

4. As disposições dos parágrafos 1 , 2 e 3 serão aplicadas a uma indicação geográfica que, embora literalmente verdadeira no que se refere ao território, região ou localidade da qual o produto se origina, dê ao público a falsa idéia de que esses bens se originam em outro território.

\section{ARTIGO 23}

\section{Proteção Adicional às Indicações Geográficas para Vinhos e Destilados}

1. Cada Membro proverá os meios legais para que as partes interessadas possam evitar a utilização de uma indicação geográfica que identifique vinhos em vinhos não originários do lugar indicado pela indicação geográfica em questão, ou que identifique destilados como destilados não originários do lugar indicado pela indicação geográfica em questão, mesmo quando a verdadeira origem dos bens esteja indicada ou a indicação geográfica utilizada em tradução ou acompanhada por expressões como "espécie", "tipo", "estilo", "imitação" ou outras similares. 
2. O registro de uma marca para vinhos que contenha ou consista em uma indicação geográfica que identifique vinhos, ou para destilados que contenha ou consista em uma indicação geográfica que identifique destilados, será recusado ou invalidado, ex officio, se a legislação de um Membro assim o permitir, ou a pedido de uma parte interessada, para os vinhos ou destilados que não tenham essa origem.

3. No caso de indicações geográficas homônimas para vinhos, a proteção será concedida para cada indicação, sem prejuízo das disposições do parágrafo 4 do ARTIGO 22. Cada Membro determinará as condições práticas pelas quais serão diferenciadas entre si as indicações geográficas homônimas em questão, levando em consideração a necessidade de assegurar tratamento eqüitativo aos produtores interessados e de não induzir a erro os consumidores. 4. Para facilitar a proteção das indicações geográficas para vinhos, realizar-se-ão, no Conselho para TRIPS, negociações relativas ao estabelecimento de um sistema multilateral de notificação e registro de indicações geográficas para vinhos passíveis de proteção nos Membros participantes desse sistema.

\section{ARTIGO 24}

\section{Negociações Internacionais; Exceções}

1. Os Membros acordam entabular negociações com o objetivo de aumentar a proteção às indicações geográficas específicas mencionadas no ARTIGO 23. As disposições dos parágrafos 4 a 8 abaixo não serão utilizadas por um Membro como motivo para deixar de conduzir negociações ou de concluir acordos bilaterais e multilaterais. No contexto de tais negociações, os Membros se mostrarão dispostos a considerar a aplicabilidade ulterior dessas disposições a indicações geográficas especificas cuja utilização tenha sido o objeto dessas negociações.

2. O Conselho para TRIPS manterá sob revisão a aplicação das disposições desta Seção; a primeira dessas revisões será realizada dentro de dois anos da entrada em vigor do Acordo Constitutivo da OMC. Qualquer questão que afete o cumprimento das obrigações estabelecidas nessas disposições poderá ser levada à atenção do Conselho, o qual, a pedido de um Membro, realizará consultas com qualquer outro Membro ou Membros sobre as questões para as quais não tenha sido possível encontrar uma solução satisfatória mediante consultas bilaterais ou multilaterais entre os Membros interessados. O conselho adotará as medidas que se acordem para facilitar o funcionamento e para a consecução dos objetivos dessa Seção.

3. Ao implementar as disposições dessa Seção, nenhum Membro reduzirá a proteção às indicações geográficas que concedia no período imediatamente anterior à data de entrada em vigor do Acordo Constitutivo da OMC.

4. Nada nesta Seção exigirá que um Membro evite o uso continuado e similar de uma determinada indicação geográfica de outro Membro, que identifique vinhos e destilados em relação a bens e serviços, por nenhum de seus nacionais ou domiciliários que tenham utilizado esta indicação geográfica de forma continuada para esses mesmos bens e serviços, ou outros afins, no território desse Membro (a) por, no mínimo, 10 anos antes de 15 de abril de 1994 ou, (b) de boa fé, antes dessa data.

5. As medidas adotadas para implementar esta Seção não prejudicarão a habilitação ao registro, a validade do registro, nem o direito ao uso de uma marca, com base no fato de que essa marca é idêntica ou similar a uma indicação geográfica, quando essa marca tiver sido solicitada ou registrada de boa fé, ou quando os direitos a essa marca tenham sido adquiridos de boa fé mediante uso: a) antes da data de aplicação dessas disposições naquele Membro, segundo estabelecido na Parte VI; ou b) antes que a indicação geográfica estivesse protegida no seu país de origem;

6. Nada nesta Seção obrigará um Membro aplicar suas disposições a uma indicação geográfica de qualquer outro Membro relativa a bens e serviços para os quais a indicação pertinente seja idêntica ao termo habitual em linguagem corrente utilizado como nome comum para os mesmos bens e serviços no território daquele Membro. Nada do previsto nesta Seção obrigará um Membro a aplicar suas disposições a uma indicação geográfica de qualquer outro Membro relativa a produtos de viticultura para os quais a indicação relevante seja igual ao nome habitual para uma variedade de 
uva existente no território daquele Membro na data da entrada em vigor do Acordo Constitutivo da OMC.

7. Um Membro poderá estabelecer que qualquer requerimento formulado no âmbito desta Seção, relativo ao uso ou registro de uma marca, deve ser apresentado dentro de um prazo de cinco anos após tornado do conhecimento geral naquele Membro o uso sem direito da indicação protegida, ou após a data do registro da marca naquele Membro, desde que a marca tenha sido publicada até aquela data, quando anterior à data na qual o uso sem direito tornou-se do conhecimento geral naquele Membro, desde que a indicação geográfica não seja utilizada ou registrada de má fé.

8. As disposições desta Seção não prejudicarão de forma alguma o direito de qualquer pessoa de usar, em operações comerciais, seu nome ou o de seu predecessor no negócio, exceto quando esse nome for utilizado de maneira que induza o público a erro.

9. Não haverá, neste Acordo, obrigação de proteger indicações geográficas que não estejam protegidas, que tenham deixado de estar protegidas ou que tenham caído em desuso no seu país de origem.

SEÇÃO 4:

\section{DESENHOS INDUSTRIAIS}

\section{ARTIGO 25}

\section{Requisitos para a Proteção}

1. Os Membros estabelecerão proteção para desenhos industriais criados independentemente, que sejam novos ou originais. Os Membros poderão estabelecer que os desenhos não serão novos ou originais se estes não diferirem significativamente de desenhos conhecidos ou combinações de características de desenhos conhecidos. Os Membros poderão estabelecer que essa proteção não se estenderá a desenhos determinados essencialmente por considerações técnicas ou funcionais.

2. Cada Membro assegurará que os requisitos para garantir proteção a padrões de tecidos particularmente no que se refere a qualquer custo, exame ou publicação - não dificulte injustificavelmente a possibilidade de buscar e de obter essa proteção. Os Membros terão liberdade para cumprir com essa obrigação por meio de lei sobre desenhos industriais ou mediante lei de direito autoral.

\section{ARTIGO 26}

\section{Proteção}

1. O titular de um desenho industrial protegido terá o direito de impedir terceiros, sem sua autorização, de fazer, vender ou importar Artigos que ostentem ou incorporem um desenho que constitua um cópia, ou seja substancialmente uma cópia, do desenho protegido, quando esses atos sejam realizados com fins comerciais.

2. Os Membros poderão estabelecer algumas exceções à proteção de desenhos industriais, desde que tais exceções não conflitem injustificavelmente com a exploração normal de desenhos industriais protegidos, nem prejudiquem injustificavelmente o legítimo interesse do titular do desenho protegido, levando em conta o legítimo interesse de terceiros. 3. A duração da proteção outorgada será de, pelo menos, dez anos. 


\section{SEÇÃO 5:}

\section{PATENTES}

\section{ARTIGO 27}

\section{Matéria Patenteável}

1. Sem prejuízo do disposto nos parágrafos 2 e 3 abaixo, qualquer invenção, de produto ou de processo, em todos os setores tecnológicos, será patenteável, desde que seja nova, envolva um passo inventivo e seja passível de aplicação industrial. Sem prejuízo do disposto no parágrafo 4 do Artigo 65, no parágrafo 8 do Artigo 70 e no parágrafo 3 deste Artigo, as patentes serão disponíveis e os direitos patentários serão usufruíveis sem discriminação quanto ao local de invenção, quanto a seu setor tecnológico e quanto ao fato de os bens serem importados ou produzidos localmente.

2. Os Membros podem considerar como não patenteáveis invenções cuja exploração em seu território seja necessário evitar para proteger a ordem pública ou a moralidade, inclusive para proteger a vida ou a saúde humana, animal ou vegetal ou para evitar sérios prejuízos ao meio ambiente, desde que esta determinação não seja feita apenas por que a exploração é proibida por sua legislação.

3. Os Membros também podem considerar como não patenteáveis: a) métodos diagnósticos, terapêuticos e cirúrgicos para o tratamento de seres humanos ou de animais; b) plantas e animais, exceto microorganismos e processos essencialmente biológicos para a produção de plantas ou animais, excetuando-se os processos não-biológicos e microbiológicos. Não obstante, os Membros concederão proteção a variedades vegetais, seja por meio de patentes, seja por meio de um sistema sui generis eficaz, seja por uma combinação de ambos. O disposto neste subparágrafo será revisto quatro anos após a entrada em vigor do Acordo Constitutivo da OMC.

\section{ARTIGO 28}

\section{Direitos Conferidos}

1. Uma patente conferirá a seu titular os seguintes direitos exclusivos: a) quando o objeto da patente for um produto, o de evitar que terceiros sem seu consentimento produzam usem, coloquem a venda, vendam, ou importem com esses propósitos aqueles bens; b) quando o objeto da patente for um processo, o de evitar que terceiros sem seu consentimento usem o processo, usem, coloquem a venda, vendam, ou importem com esses propósitos pelo menos o produto obtido diretamente por aquele processo.

2. Os titulares de patente terão também o direito de cedê-la ou transferi-la por sucessão e o de efetuar contratos de licença.

\section{ARTIGO 29}

Condições para os Requerentes de Patente

1. Os Membros exigirão que um requerente de uma patente divulgue a invenção de modo suficientemente claro e completo para permitir que um técnico habilitado possa realizá-la e podem exigir que o requerente indique o melhor método de realizar a invenção que seja de seu conhecimento no dia do pedido ou, quando for requerida prioridade, na data prioritária do pedido.

2. Os Membros podem exigir que o requerente de uma patente forneça informações relativas a seus pedidos correspondentes de patente e às concessões no exterior.

\section{ARTIGO 30}

Exceções aos Direitos Conferidos

Os Membros poderão conceder exceções limitadas aos direitos exclusivos conferidos pela patente, desde que elas não conflitem de forma não razoável com sua exploração normal e não prejudiquem 
de forma não razoável os interesses legítimos de seu titular, levando em conta os interesses legítimos de terceiros.

\section{ARTIGO 31}

\section{Outro Uso sem Autorização do Titular}

Quando a legislação de um Membro permite outro uso do objeto da patente sem a autorização de seu titular, inclusive o uso pelo Governo ou por terceiros autorizados pelo governo, as seguintes disposições serão respeitadas:

a) a autorização desse uso será considerada com base no seu mérito individual;

b) esse uso só poderá ser permitido se o usuário proposto tiver previamente buscado obter autorização do titular, em termos e condições comerciais razoáveis, e que esses esforços não tenham sido bem sucedidos num prazo razoável. Essa condição pode ser dispensada por um Membro em caso de emergência nacional ou outras circunstâncias de extrema urgência ou em casos de uso público nãocomercial. No caso de uso público não-comercial, quando o Governo ou o contratante sabe ou tem base demonstrável para saber, sem proceder a uma busca, que uma patente vigente é ou será usada pelo ou para o Governo, o titular será prontamente informado;

c) o alcance e a duração desse uso será restrito ao objetivo para o qual foi autorizado e, no caso de tecnologia de semicondutores, será apenas para uso público não-comercial ou para remediar um procedimento determinado como sendo anticompetitivo ou desleal após um processo administrativo ou judicial;

d) esse uso será não-exclusivo;

e) esse uso não será transferível, exceto conjuntamente com a empresa ou parte da empresa que dele usufruir;

f) esse uso será autorizado predominantemente para suprir o mercado interno do Membro que autorizou;

g) sem prejuízo da proteção adequada dos legítimos interesses das pessoas autorizadas, a autorização desse uso poderá ser terminada se e quando as circunstâncias que o propiciaram deixarem de existir e se for improvável que venham a existir novamente. A autoridade competente terá o poder de rever, mediante pedido fundamentado, se essas circunstâncias persistem;

h) o titular será adequadamente remunerado nas circunstâncias de cada uso, levando-se em conta o valor econômico da autorização;

i) a validade legal de qualquer decisão relativa à autorização desse uso estará sujeita a recurso judicial ou outro recurso independente junto a uma autoridade claramente superior naquele Membro;

j) qualquer decisão sobre a remuneração concedida com relação a esse uso estará sujeita a recurso judicial ou outro recurso independente junto a uma autoridade claramente superior naquele Membro;

k) os Membros não estão obrigados a aplicar as condições estabelecidas nos subparágrafos (b) e (f) quando esse uso for permitido para remediar um procedimento determinado como sendo anticompetitivo ou desleal após um processo administrativo ou judicial. A necessidade de corrigir práticas anticompetitivas ou desleais pode ser levada em conta na determinação da remuneração em tais casos. As autoridades competentes terão o poder de recusar a terminação da autorização se e quando as condições que a propiciam forem tendentes a ocorrer novamente;

l) quando esse uso é autorizado para permitir a exploração de uma patente ("a segunda patente") que não pode ser explorada sem violar outra patente ("a primeira patente"), as seguintes condições adicionais serão aplicadas: 
(i) a invenção identificada na segunda patente envolverá um avanço técnico importante de considerável significado econômico em relação à invenção identificada na primeira patente;

(ii) o titular da primeira patente estará habilitado a receber uma licença cruzada, em termos razoáveis, para usar a invenção identificada na segunda patente; e

(iii) o uso autorizado com relação à primeira patente será não transferível, exceto com a transferência da segunda patente.

ARTIGO 32

Nulidade/Caducidade

Haverá oportunidade para recurso judicial contra qualquer decisão de anular ou de caducar uma patente.

\section{ARTIGO 33}

Vigência

A vigência da patente não será inferior a um prazo de 20 anos, contados a partir da data do depósito.

\section{ARTIGO 34}

Patentes de Processo: Ônus da Prova

1. Para os fins de processos cíveis relativos à infração dos direitos do titular referidos no parágrafo 1(b) do ARTIGO 28, se o objeto da patente é um processo para a obtenção de produto, as autoridades judiciais terão o poder de determinar que o réu prove que o processo para a obter um produto idêntico é diferente do processo patenteado. Consequentemente, os Membros disporão que qualquer produto idêntico, quando produzido sem o consentimento do titular, será considerado, na ausência de prova em contrário, como tendo sido obtido a partir do processo patenteado, pelo menos em uma das circunstâncias seguintes:

a) se o produto obtido pelo processo patenteado for novo;

b) se existir probalidade significativa de o produto idêntico ter sido feito pelo processo e o titular da patente não tiver sido capaz, depois de empregar razoáveis esforços, de determinar o processo efetivamente utilizado.

2. Qualquer Membro poderá estipular que o ônus da prova indicado no parágrafo 1 recairá sobre a pessoa a quem se imputa a infração apenas quando satisfeita a condição referida no subparágrafo (a) ou apenas quando satisfeita a condição referida no subparágrafo(b).

3. Na adução da prova em contrário, os legítimos interesses dos réus na proteção de seus segredos de negócio e de fábrica serão levados em consideração.

SEÇÃO 6:

TOPOGRAFIAS DE CIRCUITOS INTEGRADOS

ARTIGO 35

Relação com o Tratado sobre a Propriedade Intelectual em Matéria de Circuitos Integrados Os Membros acordam outorgar proteção às topografias de circuitos integrados(denominados adiante "topografias") em conformidade com os Artigos 2 a 7 (salvo o parágrafo 3 do Artigo 6), Artigo 12 e parágrafo 3 do Artigo 16 do Tratado sobre Propriedade Intelectual em Matéria de Circuitos Integrados e, adicionalmente, em cumprir com as disposições seguintes. 


\section{ARTIGO 36}

\section{Abrangência da Proteção}

Sem prejuízo do disposto no parágrafo 1 do Artigo 37, os Membros considerarão ilícitos os seguintes atos, se realizados sem autorização do titular do direito: importar, vender ou distribuir por outro modo para fins comerciais uma topografia protegida, um circuito integrado no qual esteja incorporada uma topografia protegida ou um Artigo que incorpore um circuito integrado desse tipo, somente na medida em que este continue a conter uma reprodução ilícita de uma topografia.

\section{ARTIGO 37}

Atos que não Exigem a Autorização do Titular do Direito

1. Sem prejuízo do Disposto no Artigo 36, nenhum Membro considerará ilícita a realização de qualquer dos atos a que se refere aquele Artigo em relação a um circuito integrado que contenha uma topografia reproduzida de forma ilícita ou a qualquer produto que incorpore um tal circuito integrado, quando a pessoa que tenha efetuado ou ordenado tais atos não sabia e não tinha base razoável para saber, quando da obtenção do circuito integrado ou do produto, que ele continha uma topografia reproduzida de forma ilícita. Os Membros disporão que, após essa pessoa ter sido suficientemente informada de que a topografia fora reproduzida de forma ilícita, ela poderá efetuar qualquer daqueles atos com relação ao estoque disponível ou previamente encomendado, desde que pague ao titular do direito uma quantia equivalente a uma remuneração razoável, equivalente à que seria paga no caso de uma licença livremente negociada daquela topografia.

2. As condições estabelecidas nos subparágrafos (a) a (k) do Artigo 31 aplicar-se-ão, mutatis mutandis, no caso de qualquer licenciamento não-voluntário de uma topografia ou de seu uso pelo ou para o Governo sem a autorização do titular do direito.

\section{ARTIGO 38}

\section{Duração da Proteção}

1. Nos Membros que exigem o registro como condição de proteção, a duração da proteção de topografias não expirará antes de um prazo de dez anos contados do depósito do pedido de registro ou da primeira exploração comercial, onde quer que ocorra no mundo.

2. Nos Membros que não exigem registro como condição de proteção, as topografias serão protegidas por um prazo não inferior a dez anos da data da primeira exploração comercial, onde quer que ocorra no mundo.

3. Sem prejuízo dos parágrafos 1 e 2, um Membro pode dispor que a proteção terminará quinze anos após a criação da topografia.

\section{SEÇÃO 7:}

\section{PROTEÇÃO DE INFORMAÇÃO CONFIDENCIAL ARTIGO 39}

1. Ao assegurar proteção efetiva contra competição desleal, como disposto no ARTIGO 10bis da Convenção de Paris(1967), os Membros protegerão informação confidencial de acordo com o parágrafo 2 abaixo, e informação submetida a Governos ou a Agências Governamentais, de acordo com o parágrafo 3 abaixo.

2. Pessoas físicas e jurídicas terão a possibilidade de evitar que informação legalmente sob seu controle seja divulgada, adquirida ou usada por terceiros, sem seu consentimento, de maneira contrária a práticas comerciais honestas, desde que tal informação:

a) seja secreta, no sentido de que não seja conhecida em geral nem facilmente acessível a pessoas de círculos que normalmente lidam com o tipo de informação em questão, seja como um todo, seja na configuração e montagem específicas de seus componentes;

b) tenha valor comercial por ser secreta; e 
c) tenha sido objeto de precauções razoáveis, nas circunstâncias, pela pessoa legalmente em controle da informação, para mantê-la secreta.

3.Os Membros que exijam a apresentação de resultados de testes ou outros dados não divulgados, cuja elaboração envolva esforço considerável, como condição para aprovar a comercialização de produtos farmacêuticos ou de produtos agrícolas químicos que utilizem novas entidades químicas, protegerão esses dados contra seu uso comercial desleal. Ademais, os Membros adotarão providências para impedir que esses dados sejam divulgados, exceto quando necessário para proteger o público, ou quando tenham sido adotadas medidas para assegurar que os dados sejam protegidos contra o uso comercial desleal.

SEÇÃO 8:

\section{CONTROLE DE PRÁTICAS DE CONCORRÊNCIA DESLEAL EM CONTRATOS DE LICENÇAS}

\section{ARTIGO 40}

1. Os Membros concordam que algumas práticas ou condições de licenciamento relativas a direitos de propriedade intelectual que restringem a concorrência podem afetar adversamente o comércio e impedir a transferência e disseminação de tecnologia.

2. Nenhuma disposição deste Acordo impedirá que os Membros especifiquem em suas legislações condições ou práticas de licenciamento que possam, em determinados casos, constituir um abuso dos direitos de propriedade intelectual que tenha efeitos adversos sobre a concorrência no mercado relevante. Conforme estabelecido acima, um Membro pode adotar, de forma compatível com as outras disposições deste Acordo, medidas apropriadas para evitar ou controlar tais práticas, que podem incluir, por exemplo, condições de cessão exclusiva, condições que impeçam impugnações da validade e pacotes de licenças coercitivas, à luz das leis e regulamentos pertinentes desse Membro.

3. Cada Membro aceitará participar de consultas quando solicitado por qualquer outro Membro que tenha motivo para acreditar que um titular de direitos de propriedade intelectual, que seja nacional ou domiciliado no Membro ao qual o pedido de consultas tenha sido dirigido, esteja adotando práticas relativas à matéria da presente Seção, em violação às leis e regulamentos do Membro que solicitou as consultas e que deseja assegurar o cumprimento dessa legislação, sem prejuízo de qualquer ação legal e da plena liberdade de uma decisão final por um ou outro Membro. O Membro ao qual tenha sido dirigida a solicitação dispensará consideração plena e receptiva às consultas com o Membro solicitante, propiciará adequada oportunidade para sua realização e cooperará mediante o fornecimento de informações não confidenciais, publicamente disponíveis, que sejam de relevância para o assunto em questão, e de outras informações de que disponha o Membro, sujeito à sua legislação interna e à conclusão de acordos mutuamente satisfatórios relativos à salvaguarda do seu caráter confidencial pelo Membro solicitante.

4. Um Membro, cujos nacionais ou pessoas nele domiciliadas estejam sujeitas ações judiciais em outro Membro, relativas a alegada violação de leis e regulamentos desse outro Membro em matéria objeto desta Seção, terá oportunidade, caso assim o solicite, para efetuar consultas na mesmas condições previstas no parágrafo 3. 


\section{PARTE III}

\section{APLICAÇÃO DE NORMAS DE PROTEÇÃO DOS DIREITOS DE PROPRIEDADE INTELECTUAL}

SEÇÃO 1:

OBRIGAÇÕES GERAIS

\section{ARTIGO 41}

1. Os Membros assegurarão que suas legislações nacionais disponham de procedimentos para a aplicação de normas de proteção como especificadas nesta Parte, de forma a permitir uma ação eficaz contra qualquer infração dos direitos de propriedade intelectual previstos neste Acordo, inclusive remédios expeditos destinados a prevenir infrações e remédios que constituam um meio de dissuasão contra infrações ulteriores. Estes procedimentos serão aplicados de maneira a evitar a criação de obstáculos ao comércio legítimo e a prover salvaguardas contra seu uso abusivo.

2. Os procedimentos relativos a aplicação de normas de proteção dos direitos de propriedade intelectual serão justos e eqüitativos. Não serão desnecessariamente complicados ou onerosos, nem comportarão prazos não razoáveis ou atrasos indevidos.

3. As decisões sobre o mérito de um caso serão, de preferência, escritas e fundamentadas. Estarão à disposição, pelo menos das partes do processo, sem atraso indevido. As decisões sobre o mérito de um caso serão tomadas apenas com base em provas sobre as quais as partes tenham tido oportunidade de se manifestar.

4. As Partes de um processo terão a oportunidade de que uma autoridade judicial reveja as decisões administrativas finais e pelo menos os aspectos legais das decisões judiciais iniciais sobre o mérito do pedido, sem prejuízo das disposições jurisdicionais da legislação de um Membro relativa a importância do caso. Não haverá obrigação, contudo, de prover uma oportunidade para revisão de absolvições em casos criminais.

5. O disposto nesta Parte não cria qualquer obrigação de estabelecer um sistema jurídico para aplicação de normas de proteção da propriedade intelectual distinto do já existente para aplicação da legislação em geral. Nenhuma das disposições desta Parte cria qualquer obrigação com relação à distribuição de recursos entre a aplicação de normas destinadas à proteção dos direitos de propriedade intelectual e a aplicação da legislação em geral.

\section{SEÇÃO 2:}

\section{PROCEDIMENTOS E REMÉDIOS CIVIS E ADMINISTRATIVOS}

\section{ARTIGO 42}

\section{Procedimentos Justos e Eqüitativos}

Os Membros farão com que os titulares de direito possam dispor de procedimentos judiciais civis relativos à aplicação de normas de proteção de qualquer direito de propriedade intelectual coberto por este Acordo. Os réus terão direito a receber, em tempo hábil, intimação por escrito que contenha detalhes suficientes, inclusive as razões das pretensões. Será permitido às partes fazer-se representar por um advogado independente e os procedimentos não imporão exigências excessivas quanto à obrigatoriedade de comparecimento pessoal. Todas as partes nesses procedimentos estarão devidamente habilitadas a fundamentar suas pretensões e a apresentar todas as provas pertinentes. O procedimento fornecerá meios para identificar e proteger informações confidenciais, a menos que isto seja contrário a disposições constitucionais vigentes. 


\section{ARTIGO 43}

\section{Provas}

1. Quando uma parte tiver apresentado provas razoavelmente acessíveis, suficientes para sustentar suas pretensões e tiver indicado provas relevantes para a fundamentação de suas pretensões que estejam sob o controle da parte contrária, as autoridades judiciais terão o poder de determinar que esta apresente tais provas, sem prejuízo, quando pertinente, das condições que asseguram proteção da informação confidencial.

2. Nos casos em que uma das parte no processo denegue, voluntariamente ou sem motivos válidos, acesso a informação necessária, ou não a forneça dentro de prazo razoável, ou obstaculize significativamente um procedimento relativo a uma ação de aplicação de normas de proteção, um Membro pode conceder às autoridades judiciais o poder de realizar determinações judiciais preliminares e finais, afirmativas ou negativas, com base nas informações que lhes tenham sido apresentadas, inclusive a reclamação ou a alegação apresentada pela parte adversamente afetada pela recusa de acesso à informação, sob condição de conceder às partes oportunidade de serem ouvidas sobre as alegações ou provas.

\section{ARTIGO 44}

\section{Ordens Judiciais}

1. As autoridades judiciais terão o poder de determinar que uma parte cesse uma violação, inter alia para impedir a entrada nos canais de comércio sob sua jurisdição de bens importados que envolvam violação de um direito de propriedade intelectual, imediatamente após a liberação alfandegária de tais bens. Os Membros não estão obrigados a conceder este poder com relação a matéria protegida, que tenha sido adquirida ou encomendada por uma pessoa antes de saber, ou de ter motivos razoáveis para saber, que operar com essa matéria ensejaria a violação de um direito de propriedade intelectual.

2. Não obstante as demais disposições desta Parte e desde que respeitadas as disposições desta Parte e desde que respeitadas as disposições da Parte II, relativas especificamente à utilização por Governos, ou por terceiros autorizados por um Governo, sem a autorização do titular do direito, os Membros poderão limitar os remédios disponíveis contra tal uso ao pagamento de remuneração, conforme o disposto na alínea (h) do ARTIGO 31. Nos outros casos, os remédios previstas nesta Parte serão aplicados ou, quando esses remédios forem incompatíveis com a legislação de um Membro, será possível obter sentenças declaratórias e compensação adequada.

\section{ARTIGO 45}

Indenizações

1. As autoridades judiciais terão o poder de determinar que o infrator pague ao titular do direito uma indenização adequada para compensar o dano que este tenha sofrido em virtude de uma violação de seu direito de propriedade intelectual cometido por um infrator que tenha efetuado a atividade infratora com ciência, ou com base razoável para ter ciência.

2. As autoridades judiciais terão também o poder de determinar que o infrator pague as despesas do titular do direito, que poderão incluir os honorários apropriados de advogado. Em casos apropriados, os Membros poderão autorizar as autoridades judiciais a determinar a reparação e/ou o pagamento de indenizações previamente estabelecidas, mesmo quando o infrator não tenha efetuado a atividade infratora com ciência, ou com base razoável para ter ciência.

\section{ARTIGO 46}

\section{Outros Remédios}

A fim de estabelecer um elemento de dissuasão eficaz contra violações, as autoridades judiciais terão o poder de determinar que bens, que se tenha determinado sejam bens que violem direitos de propriedade intelectual, sejam objeto de disposição fora dos canais comerciais, sem qualquer forma 
de compensação, de tal maneira a evitar qualquer prejuízo ao titular do direito, ou, quando esse procedimento for contrário a requisitos constitucionais em vigor, que esses bens sejam destruídos. As autoridades judiciais terão também o poder de determinar que materiais e implementos cujo uso predominante tenha sido o de elaborar os bens que violam direitos de propriedade intelectual sejam objeto de disposição fora dos canais comerciais, sem qualquer forma de compensação, de maneira a minimizar os riscos de violações adicionais. Na consideração desses, pedidos será levada em conta a necessidade de proporcionalidade entre a gravidade da violação e os remédios determinados, bem como os interesses de terceiras partes. Com relação a bens com marca contrafeita, a simples remoção da marca ilicitamente afixada não será suficiente para permitir a liberação dos bens nos canais de comércio, a não ser em casos excepcionais.

\section{ARTIGO 47}

\section{Direito à Informação}

Os Membros poderão dispor que as autoridades judiciais tenham o poder de determinar que o infrator informe ao titular do direito a identidade de terceiras pessoas envolvidas na produção e distribuição dos bens ou serviços que violem direitos de propriedade intelectual e de seus canais de distribuição, a menos que isto seja desproporcional à gravidade da violação.

\section{ARTIGO 48}

\section{Indenização do Réu}

1. As autoridades judiciais terão o poder de determinar que uma parte, a pedido da qual tenham sido tomadas medidas e que tenham abusado dos procedimentos de aplicação de normas de proteção de direitos de propriedade intelectual, provenha à parte que tenha sido equivocadamente objeto de ordem judicial ou de medida cautelar compensação adequada pelo prejuízo em que incorreu por conta desse abuso. As autoridades judiciais terão também o poder de determinar ao demandante que pague as despesas do réu, que podem incluir honorários adequados de advogado.

2. Os Membros só poderão isentar autoridades e funcionários públicos de estarem sujeitos a medidas apropriadas de reparação relativas à aplicação de qualquer lei sobre a proteção ou a observância de direitos de propriedade intelectual, quando as ações tiverem sido efetuadas ou pretendidas de boa fé, no contexto da aplicação daquela legislação.

\section{ARTIGO 49}

\section{Procedimentos Administrativos}

$\mathrm{Na}$ medida em que qualquer remédio cível possa ser determinado como decorrência de procedimentos administrativos sobre o mérito de um caso, esses procedimentos conformar-se-ão a princípios substantivamente equivalentes aos estabelecidos nesta Seção.

\section{SEÇÃO 3:}

\section{MEDIDAS CAUTELARES}

\section{ARTIGO 50}

1. As autoridades judiciais terão o poder de determinar medidas cautelares rápidas e eficazes:

a) para evitar a ocorrência de uma violação de qualquer direito de propriedade intelectual em especial para evitar a entrada nos canais comerciais sobre sua jurisdição de bens, inclusive de bens importados, imediatamente após sua liberação alfandegária;

b) para preservar provas relevantes relativas a uma alegada violação.

2. As autoridades judiciais terão o poder de adotar medidas cautelares, inaudita altera parte, quando apropriado em especial quando qualquer demora tenderá a provocar dano irreparável ao titular do direito, ou quando exista um risco comprovado de que as provas sejam destruídas. 
3. As autoridades judiciais terão o poder de exigir que o requerente forneça todas as provas razoavelmente disponíveis de modo a se convencer com grau suficiente de certeza, que o requerente é o titular do direito e que seu direito está sendo violado ou que tal violação é iminente e de determinar que o requerente deposite uma caução ou garantia equivalente suficiente para proteger o réu e evitar abuso.

4. Quando medidas cautelares tenham sido adotadas inaudita altera parte, as partes afetadas serão notificadas sem demora, no mais tardar após a execução das medidas. Uma revisão, inclusive direito a ser ouvido, terá lugar mediante pedido do réu, com vistas a decidir , dentro de um prazo razoável após a notificação das medidas, se essas medidas serão alteradas, revogadas ou mantidas.

5. A autoridade que executará as medidas cautelares poderá requerer ao demandante que ele provenha outras informações necessárias à identificação dos bens pertinentes.

6. Sem prejuízo do disposto no parágrafo 4, as medidas cautelares adotadas com base nos parágrafos 1 e 2 serão revogadas ou deixarão de surtir efeito, quando assim requisitado pelo réu, se o processo conducente a uma decisão sobre o mérito do pedido não for iniciado dentro de um prazo razoável. Nos casos em que a legislação de um Membro assim o permitir, esse prazo será fixado pela autoridade judicial que determinou as medidas cautelares. Na ausência de sua fixação, o prazo não será superior a 20 dias úteis ou a 31 dias corridos, o que for maior.

7. Quando as medidas cautelares forem revogadas, ou quando elas expirarem em função de qualquer ato ou omissão por parte do demandante, ou quando for subseqüentemente verificado que não houve violação ou ameaça de violação a um direito de propriedade intelectual, as autoridades judiciais quando solicitadas pelo réu, terão o poder de determinar que o demandante forneça ao réu compensação adequada pelo dano causado por essas medidas.

8. Na medida em que qualquer medida cautelar possa ser determinada como decorrência de procedimentos administrativos, esses procedimentos conformar-se-ão a princípios substantivamente equivalentes aos estabelecidos nesta Seção.

SEÇÃO 4:

\section{EXIGÊNCIAS ESPECIAIS RELATIVAS A MEDIDAS DE FRONTEIRA}

\section{ARTIGO 51}

\section{Suspensão de Liberação pelas Autoridades Alfandegárias}

Os Membros adotarão procedimentos, de acordo com as disposições abaixo, para permitir que um titular de direito, que tenha base válida para suspeitar que a importação de bens com marca contrafeita ou pirateados possa ocorrer, apresente um requerimento por escrito junto às autoridades competentes, administrativas ou judiciais, para a suspensão pelas autoridades alfandegárias da liberação desses bens.

Os Membros podem permitir que um requerimento dessa natureza seja feito com relação a bens que envolvam outras violações de direitos de propriedade intelectual, desde que as exigências desta Seção sejam satisfeitas.

Os Membros também podem permitir processos correspondentes, relativos à suspensão da liberação pelas autoridades alfandegárias de bens que violem direitos de propriedade intelectual destinados à exportação de seus territórios.

\section{ARTIGO 52}

\section{Requerimento}

Qualquer titular de direito que inicie os procedimentos previstos no ARTIGO 51 terá de fornecer provas adequadas para satisfazer as autoridades competentes, de acordo com a legislação do país de importação, que existe, prima facie, uma violação do direito de propriedade intelectual do titular do 
direito e de fornecer uma descrição suficientemente detalhada dos bens, de forma a que sejam, facilmente reconhecidos pelas autoridades alfandegárias.

As autoridades competentes informarão ao requerente, dentro de um prazo de tempo razoável, se aceitaram o requerimento e, quando determinado pelas autoridades competentes, o prazo em que agirão as autoridades alfandegárias.

\section{ARTIGO 53}

Caução ou Garantia Equivalente

1. As autoridades competentes terão o poder de exigir que o requerente deposite uma caução ou garantia equivalente, suficiente para proteger o requerido e evitar abuso. Essa caução ou garantia equivalente não deterá, despropositadamente, o recurso a esses procedimentos.

2. De acordo com o requerimento previsto nessa Seção, quando a liberação de bens envolvendo desenhos industriais, patentes, topografias de circuito integrado ou informações confidenciais tiver sido suspensa pelas autoridades alfandegárias, com base em uma decisão que não tenha sido tomada por uma autoridade judicial ou por outra autoridade independente, e o prazo estipulado no Artigo 55 tenha expirado sem a concessão de alívio provisório pelas autoridades devidamente capacitadas, o proprietário, importador ou consignatário desses bens terá direito à sua liberação quando depositar uma caução suficiente para proteger o titular do direito de qualquer violação, desde que todas as outras condições de importação tenham sido cumpridas. O pagamento dessa caução não restringirá o direito a outros remédios disponíveis para o titular do direito, ficando entendido que a caução será liberada se o titular do direito desistir do direito de litigar dentro de um prazo razoável.

\section{ARTIGO 54}

\section{Notificação de Suspensão}

O importador e o requerente serão prontamente notificados da suspensão da liberação dos bens, de acordo com o Artigo 51.

\section{ARTIGO 55}

\section{Duração da Suspensão}

Se as autoridades alfandegárias não tiverem sido informadas, num prazo de até 10 dias úteis após a notificação ao requerente da suspensão da liberação, de que um processo tendente a uma decisão sobre o mérito do pedido tenha sido iniciado por outra parte que não o réu, ou que a autoridade devidamente capacitada tenha adotado medidas cautelares prolongando a suspensão da liberação dos bens, os bens serão liberados, desde que todas as outras condições para importação e exportação tenham sido cumpridas; em casos apropriados, esse limite de tempo pode ser estendido por 10 dias úteis adicionais. Se o processo tendente a uma decisão sobre o mérito do pedido tiver sido iniciado, haverá, quando solicitada pelo réu, uma revisão, inclusive o direito de ser ouvida, a fim de se decidir, dentro de um prazo razoável, se essas medidas serão modificadas, revogadas ou confirmadas. Não obstante o acima descrito, quando a suspensão da liberação dos bens for efetuada ou mantida de acordo com uma medida judicial cautelar, serão aplicadas as disposições do parágrafo 6 do Artigo 50.

\section{ARTIGO 56}

Indenização do Importador e do Proprietário dos Bens

As autoridades pertinentes terão o poder de determinar que o requerente pague ao importador, ao consignatário e ao proprietário dos bens uma compensação adequada por qualquer dano a eles causado pela retenção injusta dos bens ou pela retenção de bens liberados de acordo com o Artigo 55. 


\section{ARTIGO 57}

Direito à Inspeção e à Informação

Sem prejuízo da proteção de informações confidenciais, os Membros fornecerão às autoridades competentes o poder de conceder ao titular do direito oportunidade suficiente para que quaisquer bens detidos pelas autoridades alfandegárias sejam inspecionados, de forma a fundamentar as pretensões do titular do direito. As autoridades competentes terão também o poder de conceder ao importador uma oportunidade equivalente para que quaisquer desses bens seja inspecionados. Quando a decisão de mérito for pela procedência do pedido, os Membros podem prover às autoridades competentes o poder de informar ao titular do direito os nomes e endereços do consignador, do importador e do consignatário e da quantidade dos bens em questão.

\section{ARTIGO 58}

\section{Ação Ex Officio}

Quando os Membros exigem que as autoridades competentes atuem por conta própria e suspendam a liberação de bens em relação aos quais elas obtiveram prova inicial de que um direito de propriedade intelectual esteja sendo violado:

a) as autoridades competentes podem buscar obter, a qualquer momento do titular do direito qualquer informação que possa assisti-las a exercer esse poder;

b) o importador e o titular do direito serão prontamente notificados da suspensão. Quando o importador tiver apresentado uma medida contra a suspensão junto às autoridades competentes, a suspensão estará sujeita, mutatis mutandis, às condições estabelecidas no Artigo 55;

c) os Membros só poderão isentar autoridades e servidores públicos de estarem sujeitos a medidas apropriadas de reparação quando os atos tiverem sido praticados ou pretendidos de boa fé.

\section{ARTIGO 59}

\section{Remédios}

Sem prejuízo dos demais direitos de ação a que faz jus o titular do direito e ao direito do réu de buscar uma revisão por uma autoridade judicial, as autoridades competentes terão o poder de determinar a destruição ou a alienação de bens que violem direitos de propriedade intelectual, de acordo com os princípios estabelecidos no ARTIGO 46. Com relação a bens com marca contrafeita, as autoridades não permitirão sua reexportação sem que sejam alterados nem os submeterão a procedimento alfandegário distinto, a não ser em circunstâncias excepcionais.

\section{ARTIGO 60}

Importações De Minimis

Os Membros poderão deixar de aplicar as disposições acima no caso de pequenas quantidades de bens, de natureza não-comercial, contidos na bagagem pessoal de viajantes ou enviados em pequenas consignações.

\section{SEÇÃO 5:}

\section{PROCEDIMENTOS PENAIS}

\section{ARTIGO 61}

Os Membros proverão a aplicação de procedimentos penais e penalidades pelo menos nos casos de contrafação voluntária de marcas e pirataria em escala comercial. Os remédios disponíveis incluirão prisão e/ou multas monetárias suficientes para constituir um fator de dissuasão, de forma compatível com o nível de penalidades aplicadas a crimes de gravidade correspondente. Em casos apropriados, os remédios disponíveis também incluirão a apreensão, perda e destruição dos bens 
que violem direitos de propriedade intelectual e de quaisquer materiais e implementos cujo uso predominante tenha sido na consecução do delito.

Os Membros podem prover a aplicação de procedimentos penais e penalidades em outros casos de violação de direitos de propriedade intelectual, em especial quando eles forem cometidos voluntariamente e em escala comercial.

PARTE IV

\section{AQUISIÇÃO E MANUTENÇÃO DE DIREITOS DE PROPRIEDADE INTELECTUAL E PROCEDIMENTOS INTERPARTES CONEXOS}

\section{ARTIGO 62}

1. Os Membros podem exigir o cumprimento de procedimentos e formalidades razoáveis, como uma condição da obtenção ou manutenção dos direitos de propriedade intelectual estabelecidos pelas Seções 2 a 6 da Parte II. Esses procedimentos e formalidades serão compatíveis com as disposições deste Acordo.

2. Quando a obtenção de um direito de propriedade intelectual estiver sujeita à concessão do direito ou a seu registro, os Membros, sem prejuízo do cumprimento dos requisitos substantivos para a obtenção dos direitos assegurarão que os procedimentos para a concessão ou registro permitam a concessão ou registro do direito num prazo razoável, de modo a evitar redução indevida do prazo de proteção.

3. O Artigo 4 da Convenção de Paris (1967) será aplicado, mutatis mutandis, a marcas de serviço.

4. Os procedimentos relativos à obtenção ou manutenção de direitos de propriedade intelectual e, quando a legislação de um Membro os tiver, os relativos à nulidade administrativa e aos procedimentos inter-partes, como oposição, anulação ou cancelamento, obedecerão os princípios gerais estabelecidos nos parágrafos 2 e 3 do Artigo 41.

5. As decisões administrativas finais em qualquer dos procedimentos previstos no Artigo 41 estará sujeita a revisão por uma autoridade judicial ou quase judicial. Não haverá obrigação, contudo, de prover uma oportunidade para essa revisão de decisões nos casos de oposição indeferida ou nulidade administrativa, desde que as razões para esses procedimentos possam estar sujeitas a procedimentos de invalidação.

\section{PARTE V PREVENÇÃO E SOLUÇÃO DE CONTROVÉRSIAS}

\section{ARTIGO 63}

\section{Transparência}

1. As leis e regulamentos e as decisões judiciais e administrativas finais de aplicação geral, relativas à matéria objeto desse Acordo ( existência, abrangência, obtenção, aplicação de normas de proteção e prevenção de abuso de direitos de propriedade intelectual) que forem colocados em vigor por um Membro serão publicadas ou, quando essa publicação não for conveniente, serão tornadas públicas, num idioma nacional, de modo a permitir que Governos e titulares de direitos delas tomem conhecimento, os Acordos relativos a matéria objeto deste Acordo, que estejam em vigor entre o Governo ou uma Agência Governamental de um Membro e o Governo ou uma Agência Governamental de um outro Membro também serão publicados.

2. Os Membros notificarão o Conselho para TRIPS das leis e regulamentos a que se refere ao parágrafo 1 , de forma a assistir aquele Conselho em sua revisão da operação deste Acordo. $\mathrm{O}$ Conselho tentará minimizar o ônus dos Membros em dar cumprimento a esta obrigação e pode decidir dispensá-los da obrigação de notificar diretamente o Conselho sobre tais leis e regulamentos se conseguir concluir com a OMPI entendimento sobre o estabelecimento de um registro comum contendo essas leis e regulamentos. Nesse sentido, o Conselho também considerará qualquer ação exigida a respeito das notificações originadas das obrigações deste Acordo derivadas das disposições do ARTIGO 6ter da Convenção de Paris (1967). 
3. Cada Membro estará preparado a suprir informações do tipo referido no parágrafo 1 em resposta a um requerimento por escrito de outro Membro. Um Membro que tenha razão para acreditar que uma decisão judicial ou administrativa específica ou um determinado acordo bilateral na área de direitos de propriedade intelectual afete seus direitos, como previstos neste Acordo, também poderá requerer por escrito permissão de consultar ou de ser informado, com suficiente detalhe, dessas decisões judiciais ou administrativas ou específicas ou desse determinado acordo bilateral.

4. Nada do disposto nos parágrafos 1, 2 e 3 exigirá que os Membros divulguem informação confidencial que impediria a execução da lei ou que seria contrária ao interesse público ou que prejudicaria os interesses comerciais legítimos de determinadas empresas, públicas ou privadas.

\section{ARTIGO 64}

\section{Solução de Controvérsias}

1. O disposto nos Artigos XXII e XXIII do GATT 1994, como elaborado e aplicado pelo entendimento de Solução e Controvérsias, será aplicado a consultas e soluções de controvérsias no contexto desse Acordo, salvo disposição contrária especificamente prevista neste Acordo.

2. Os subparágrafos 1(b) e 1(c) do ARTIGO XXIII do GATT 1994 não serão aplicados a soluções de controvérsias no contexto deste Acordo durante um prazo de cinco anos contados a partir da data de entrada em vigor do Acordo Constitutivo da OMC.

3. Durante o prazo a que se refere o parágrafo 2, o Conselho para TRIPS examinará a abrangência e as modalidades para reclamações do tipo previstos nos subparágrafos 1(b) e 1(c) do ARTIGO XXIII do GATT 1994, efetuadas em conformidade com este Acordo, e submeterão suas recomendações à Conferência Ministerial para aprovação. Qualquer decisão da Conferência Ministerial de aprovar essas recomendações ou de estender o prazo estipulado no parágrafo 2 somente será adotada por consenso. As recomendações aprovadas passarão a vigorar para todos os Membros sem qualquer processo formal de aceitação.

\section{PARTE VI}

\section{DISPOSIÇÕES TRANSITÓRIAS}

\section{ARTIGO 65}

\section{Disposições Transitórias}

1. Sem prejuízo do disposto nos parágrafos 2, 3 e 4, nenhum Membro estará obrigado a aplicar as disposições do presente Acordo antes de transcorrido um prazo geral de um ano após a data de entrada em vigor do Acordo Constitutivo da OMC.

2. Um País em desenvolvimento Membro tem direito a postergar a data de aplicação das disposições do presente Acordo, estabelecida no parágrafo 1, por um prazo de quatro anos, com exceção dos Artigos 3, 4 e 5.

3. Qualquer outro Membro que esteja em processo de transformação de uma economia de planejamento centralizado para uma de mercado e de livre empresa e esteja realizando uma reforma estrutural de seu sistema de propriedade intelectual e enfrentando problemas especiais na preparação e implementação de leis e regulamentos de propriedade intelectual, poderá também beneficiar-se de um prazo de adiamento tal como previsto no parágrafo 2.

4. Na medida em que um País em desenvolvimento Membro esteja obrigado pelo presente Acordo a estender proteção patentária de produtos a setores tecnológicos que não protegia em seu território na data geral de aplicação do presente Acordo, conforme estabelecido no parágrafo 2, ele poderá adiar a aplicação das disposições sobre patentes de produtos da Seção 5 da Parte II para tais setores tecnológicos por um prazo adicional de cinco anos. 
5. Um Membro que se utilize do prazo de transição previsto nos parágrafos 1, 2, 3 e 4 assegurará que quaisquer modificações nas suas legislações, regulamentos e prática feitas durante esse prazo não resultem em um menor grau de consistência com as disposições do presente Acordo.

\section{ARTIGO 66}

Países de Menor Desenvolvimento Relativo Membros

1. Em virtude de suas necessidades e requisitos especiais, de suas limitações econômicas, financeiras e administrativas e de sua necessidade de flexibilidade para estabelecer uma base tecnológica viável, os países de menor desenvolvimento relativo Membros não estarão obrigados a aplicar as disposições do presente Acordo, com exceção dos Artigos 3, 4 e 5, durante um prazo de dez anos contados a partir da data de aplicação estabelecida no parágrafo 1 do Artigo 65. O Conselho para TRIPS, quando receber um pedido devidamente fundamentado de um país de menor desenvolvimento relativo Membro concederá prorrogações desse prazo.

2. Os países desenvolvidos Membros concederão incentivos a empresas e instituições de seus territórios com o objetivo de promover e estimular a transferência de tecnologia aos países de menor desenvolvimento relativo Membros, a fim de habilitá-los a estabelecer uma base tecnológica sólida e viável.

\section{ARTIGO 67}

\section{Cooperação Técnica}

A fim de facilitar a aplicação do presente Acordo, os países desenvolvidos Membros, a pedido, e em termos e condições mutuamente acordadas, prestarão cooperação técnica e financeira aos países em desenvolvimento Membros e de menor desenvolvimento relativo Membros. Essa cooperação incluirá assistência na elaboração de leis e regulamentos sobre proteção e aplicação de normas de proteção dos direitos de propriedade intelectual bem como sobre a prevenção de seu abuso, e incluirá apoio ao estabelecimento e fortalecimento dos escritórios e agências nacionais competentes nesses assuntos, inclusive na formação de pessoal.

\section{PARTE VII}

\section{DISPOSIÇÕES INSTITUCIONAIS:}

\section{DISPOSIÇÕES FINAIS}

\section{ARTIGO 68}

Conselho dos Aspectos dos Direitos de Propriedade Intelectual Relacionados ao Comércio

O Conselho para TRIPS supervisionará a aplicação deste Acordo e, em particular, o cumprimento, por parte dos Membros, das obrigações por ele estabelecidas, e lhes oferecerá a oportunidade de efetuar consultas sobre questões relativas aos aspectos dos direitos de propriedade intelectual relacionados ao comércio.

O Conselho se desincumbirá de outras atribuições que lhe forem confiadas pelos Membros e, em particular, lhes prestará qualquer assistência solicitada no contexto de procedimentos de solução de controvérsias.

No desempenho de suas funções, o Conselho para TRIPS poderá consultar e buscar informações de qualquer fonte que considerar adequada. Em consulta com a OMPI, o Conselho deverá buscar estabelecer, no prazo de um ano a partir de sua primeira reunião, os arranjos apropriados para a cooperação com os órgãos daquela Organização. 


\section{ARTIGO 69}

\section{Cooperação Internacional}

Os Membros concordam em cooperar entre si com o objetivo de eliminar o comércio internacional de bens que violem direitos de propriedade intelectual. Para esse fim, estabelecerão pontos de contato em suas respectivas administrações nacionais, deles darão notificação e estarão prontos a intercambiar informações sobre o comércio de bens infratores. Promoverão, em particular, o intercâmbio de informações e a cooperação entre as autoridades alfandegárias no que tange ao comércio de bens com marca contrafeita e bens pirateados.

\section{ARTIGO 70}

\section{Proteção da Matéria Existente}

1. Este Acordo não gera obrigações relativas a atos ocorridos antes de sua data de aplicação para o respectivo Membro.

2. Salvo disposição em contrário nele prevista, este Acordo, na data de sua aplicação para o Membro em questão, gera obrigações com respeito a toda a matéria existente, que esteja protegida naquele Membro na citada data, ou que satisfaça, ou venha posteriormente a satisfazer, os critérios de proteção estabelecidos neste Acordo. Com relação ao presente parágrafo e aos parágrafos 3 e 4 abaixo, as obrigações em matéria de direito do autor relacionadas com obras existentes serão determinadas unicamente pelo disposto no Artigo 18 da Convenção de Berna ( 1971), e as obrigações relacionadas com os direitos dos produtores de fonogramas e dos artistas-intérpretes em fonogramas existentes serão determinadas unicamente pelo disposto no Artigo 18 da Convenção de Berna (1971), na forma em que foi tornado aplicável pelo disposto no parágrafo 6 do Artigo 14 deste Acordo.

3. Não haverá obrigação de restabelecer proteção da matéria, que, na data de aplicação deste Acordo para o Membro em questão, tenha caído no domínio público.

4. Com respeito a quaisquer atos relativos a objetos específicos que incorporem matéria protegida e que venham a violar direitos de propriedade intelectual, nos termos de legislação em conformidade com este Acordo, e que se tenham iniciado, ou para os quais o investimento significativo tenha sido efetuado, antes da data de aceitação do Acordo Constitutivo da OMC por aquele Membro, qualquer Membro poderá estabelecer uma limitação aos remédios disponíveis ao titular de direito com relação à continuação desses atos após a data de aplicação deste Acordo por aquele Membro. Em tais casos, entretanto, o Membro estabelecerá ao menos o pagamento de remuneração eqüitativa.

5. Nenhum Membro está obrigado a aplicar as disposições do Artigo 11 nem do parágrafo 4 do Artigo 14 a originais ou cópias compradas antes da data de aplicação deste Acordo para este Membro.

6. Os Membros não estão obrigados a aplicar o Artigo 31, nem o requisito estabelecido no parágrafo 1 do Artigo 27 segundo o qual os direitos de patente serão desfrutados sem discriminação quanto ao setor tecnológico, no tocante ao uso sem a autorização do titular do direito, quando a autorização para tal uso tenha sido concedida pelo Governo antes da data em que este Acordo tornou-se conhecido.

7. No caso de direitos de propriedade intelectual para os quais a proteção esteja condicionada ao registro será permitido modificar solicitações de proteção que se encontrem pendentes na data de aplicação deste Acordo para o Membro em questão, com vistas a reivindicar qualquer proteção adicional prevista nas disposições deste Acordo. Tais modificações não incluirão matéria nova.

8. Quando um Membro, na data de entrada em vigor do Acordo Constitutivo da OMC, não conceder proteção patentária a produtos farmacêuticos nem aos produtos químicos para a agricultura em conformidade com as obrigações previstas no Artigo 27, esse Membro: 
a) não obstante as disposições da Parte VI, estabelecerá, a partir da data de entrada em vigor do Acordo Constitutivo da OMC, um meio pelo qual os pedidos de patente para essas invenções possam ser depositados;

b) aplicará as essas solicitações, a partir da data de aplicação deste Acordo, os critérios de patentabilidade estabelecidos neste instrumento como se tais critérios estivessem sendo aplicados nesse Membro na data do depósito dos pedidos, quando uma prioridade possa ser obtida e seja reivindicada, na data de prioridade do pedido; e

c) estabelecerá proteção patentária, em conformidade com este Acordo, a partir da concessão da patente e durante o resto da duração da mesma, a contar da data de apresentação da solicitação em conformidade com o ARTIGO 33 deste Acordo, para as solicitações que cumpram os critérios de proteção referidos na Alínea (b) acima.

9. Quando um produto for objeto de uma solicitação de patente num Membro, em conformidade com o parágrafo 8 (a), serão concedidos direitos exclusivos de comercialização não obstante as disposições da Parte VI acima, por um prazo de cinco anos, contados a partir da obtenção da aprovação de comercialização nesse Membro ou até que se conceda ou indefira uma patente de produto neste Membro se esse prazo for mais breve, desde que, posteriormente à data de entrada em vigor do Acordo Constitutivo da OMC, uma solicitação de patente tenha sido apresentada e uma patente concedida para aquele produto em outro Membro e se tenha obtido a aprovação de comercialização naquele outro Membro. ARTIGO 71 Revisão e Emenda 1. O Conselho para TRIPS avaliará a aplicação deste Acordo após transcorrido o prazo de transição mencionado no parágrafo 2 do Artigo 65. Com base na experiência adquirida em sua aplicação, o Conselho empreenderá uma revisão do Acordo dois anos após aquela data e, subseqüentemente, em intervalos idênticos. O Conselho poderá também efetuar avaliações à luz de quaisquer acontecimentos novos e relevantes, que possam justificar modificação ou emenda deste Acordo. 2. As emendas que sirvam meramente para incorporar níveis mais elevados de proteção dos direitos de propriedade intelectual, alcançados e vigentes em outros acordos multilaterais, e que tenham sido aceitos no contexto desses acordos por todos os Membros da OMC, poderão ser encaminhados à Conferência Ministerial para sua deliberação, em conformidade com o disposto no parágrafo 6 do Artigo 10 do Acordo Constitutivo da OMC, a partir de uma proposta consensual do Conselho de TRIPS.

\section{ARTIGO 72}

\section{Reservas}

Não poderão ser feitas reservas com relação a qualquer disposição deste Acordo sem o consentimento dos demais Membros.

\section{ARTIGO 73}

\section{Exceções de Segurança}

Nada neste Acordo será interpretado:

a) como exigência de que um Membro forneça qualquer informação, cuja divulgação ele considere contrária a seus interesses essenciais de segurança; ou

b) como impeditivo de que um Membro adote qualquer ação que considere necessária para a proteção de seus interesses essenciais de segurança:

(i) relativos a materiais físseis ou àqueles dos quais são derivados;

(ii) relativos ao tráfico de armas, munição e material bélico e ao tráfico de outros bens e materiais efetuado, direta ou indiretamente, com o propósito de suprir estabelecimentos militares;

(iii) adotada em tempo de guerra ou de outra emergência em relações internacionais; ou c) como impeditivo de um Membro adotar qualquer ação de acordo com a Carta das Nações Unidas para a manutenção da paz e segurança internacionais. 